\title{
John Aage Gjestrum TILL MINNE
}

John Aage nämnde ibland Johannes Sivesind som sin läromästare.

Sivesind ledde museet i Toten kommun (med 25000 invånare) åren 1954-1967. Under tonåren började John Aage hjälpa till där, och tog för sin framtid och sitt museitänkande avgörande intryck av Sivesind. När han 1977 själv blev chef för Totens museum - 24-årig, den yngste av museichefer i Norge! - kom han att utveckla museet till det mönster för ett lokalmuseums möjligheter som gjorde det internationellt ryktbart.

År 1991 fyllde Sivesind 70 år. Han hade då avslutat sin yrkesgärning som chef för Borgarsyssel museum i Sarpsborg. För att hedra honom redigerade John Aage Toten museums årsbok detta år som en festskrift till Sivesind med titeln Visjon og Virke. Han beskriver Sivesind och hans verk på följande sätt:

...han har gjort det meste på sin måte, ofte i tildels sterk utakt med omgivelsene. Da ikke ved a vare for seint ute, men for tidlig; - på 1940- og 50-tallet med tverrfaglighet og helhetstenkning, på 1960-tallet med levende museum, på 1970-tallet ble Sivesind landskjent som konservatoren som restaurerer mennesker, på 1980-tallet kobler han sammen det lokale og det nordiske kulturperspektivet på nye og spennende måter. Alt i (Sivesinds) planer fra 1940-tallet finner vi filosofien bak den ideen som seinere i Frankrike ble gitt navnet "økomuseum", med hele bygda som et levende museum, - og i samfunnets tjeneste som et ledd $i$ en naturlig utvikling av lokalkulturen etter framtidas behov. De fleste som moter Sivesind fär problemer med à stille seg likegyldig. Han er et menneske som engasjerer, - og noen vil også ta det motsatte standpunkt, og avvise. Denne spenningen omkring Johannes Sivesind har antakelig alltid vart der. Han har aldri villet gi opp $i$ arbeidet med oppgavene han har valgt, og han har alltid gitt sine "motstandere" $i$ de mange vernesaker mulighet til arerik retrett. Sivesind har brukt humor ofte som likeverdig kampmiddel med faglig integritet og kunnskap. I ettertid kan vi ogsà se at hans evner til å finne losninger med positiv utgang selv i de mest häpløse prosjekter, nettopp skyldes hans spesielle blanding av psykologisk intuisjon og innbitt motvilje mot å gi opp.

Det är svårt att tänka sig en bättre beskrivning än denna av John Aages egen vision, hans eget livsverk. I den grundläggande idén om lokalmuseet som grund för ett samhälles självkännedom, i kopplingen till en lokalhistorisk forskning riktad mot tvärvetenskaplig helhetsförståelse och i öppenheten för samtidens medier fann John 
Aage sitt museologiska centrum. Till sin förvåning återfann han detta i den franska ekomuseirörelsens teori och i MINOM, ekomuseernas internationella organisation, som han kom att entusiastiskt engagera sig i. I John Aages version vidgades lokalmuseet till ett världsmuseum: i lokalmuseernas minnesskatt av föremål, traditioner och berättelser fann han ständigt reflexer av den stora världens rörelser. "Verka lokalt, tänka globalt" blev en formel som han genast anammade och ofta citerade. Men också dess omvändning blev giltig: att verka i ett globalt sammanhang - i Afrika, i Kina, i Ryssland - för den starka potentialen i lokalmuseets/ekomuseets idé blev alltmer en livsuppgift, där även ICOMs internationella kommittéer, särskilt ICOFOM och ICR, erbjöd användbara fora.

När John Aage 1989 sökte kontakt med museologin vid Umeå universitet var det i hög grad betingat av de kontakter med internationell museologisk forskning och debatt som institutionen kunde erbjuda. Åren 1992-1996 bedrev han doktorandstudier där med stöd av ett stipendium från Norges Forskningsråd. Han avsåg att slutföra arbetet på en avhandling om staden Røros som kulturarv; om kulturarv som avhängigt av över tid skiftande föreställningar om begreppets innebörd. Avhandlingen, som John Aage faktiskt arbetade med fram till sin död, blev inte avslutad. Han beskrev emellertid sitt ämne i en artikel 1999 som återges här (s.75-79).

Den 3-4 mars 1993 anordnade danska Museumshøjskolen sina första museologiska föreläsningar i Nationalmuseet, Köpenhamn. På kvällen den 3 mars framlade John Aage idén till tidskriften Nordisk Museologi för att bland annat kunna ge nordisk spridning åt de föreläsningar som presenterats. Åtta årgångar hann John Aage med sin aldrig sviktande energi, sin entusiasm och sina internationella kontakter faktiskt förverkliga. Istället för en festskrift till John Aage får vi nöja oss med ett minnesnummer av Nordisk Museologi, vars fortsatta utgivning vi hoppas skall bli en mer varaktig tribut till hans vision och livsverk.

Med två rader av Karin Boye gav oss Elisabeth Nordengen i dödsannonsen en nyckel till sin makes väsen:

Så skall du finna livet starkt

som orkar brinna 
Minnesdelen SOM InLeder DetTA Dubbelnummer återger ett urval texter av John Aage Gjestrum.

I den följande delen reflekterar Maria do Céu Baptista om vad ett industriminne i vardande i spanska Asturien kan lära av det etablerade industriminnet Røros; Odd Are Berkaak diskuterar en möjlig nyorientering av samtidsdokumentation; Esben Kjeldbaek karakteriserar tre museigenerationer; Line Hjorth analyserar begreppet reflexiv utställning; Olav Aaraas skriver om utställningstexter; Jørgen Hein utreder skillnaden mellan konstkammare och skattkammare i museihistoriens gryning; Janne Vilkuna diskuterar de etiska frågorna kring utställandet av döda människor. Med klassikertexten erinrar vi om Carl-Axel Moberg, arkeolog, museiman, pedagog och poet.

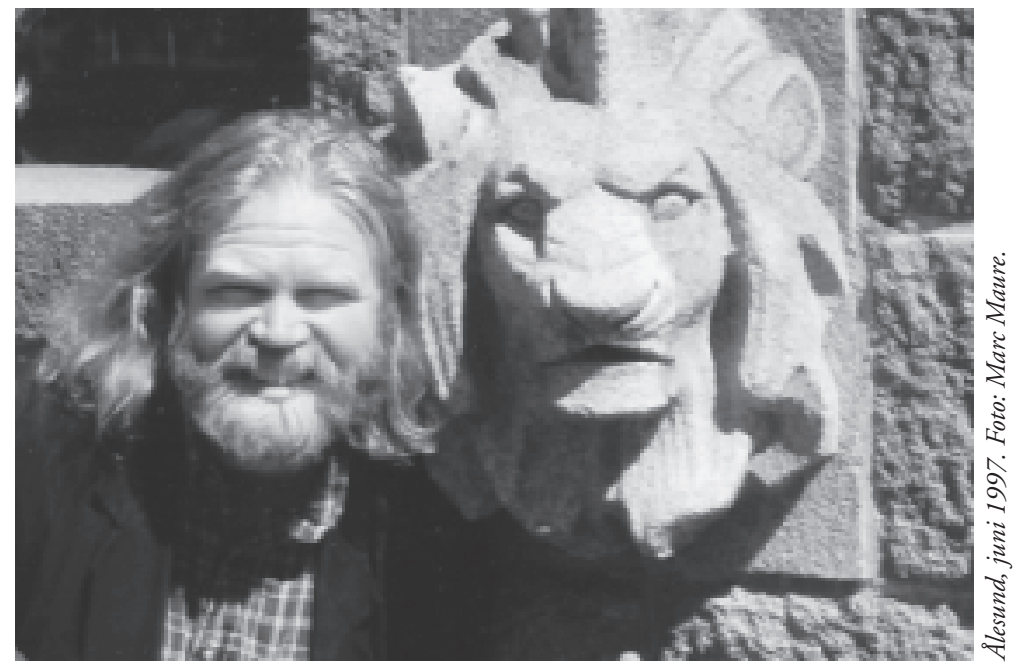

\section{John Aage Gjestrum in memoriam}

This issue of Nordisk Museologi is dedicated to the memory of one of its founding fathers - and undoubtedly the most important one. He died unexpectedly at the age of 48 a year ago on the 6th of April in Krasnoyark, Sibiria. In order to give a comprehensive idea of John Aage Gjestrums work and thinking, a selection of his writings is offered on pp. 397. A brief summary of the texts can be found on p. 101 and his bibliography ('tryckta skrifter') on p. 96-100. 
Nordisk Museologi 200I • I-2, S. 4-II

\title{
DA FYRSTIKKFABRIKKEN BLE BYGGET
}

\author{
John Aage Gjestrum
}

En liten sensasjon var det i sommer da Terje Vegar Larsen kom innom arkivet på Stenberg med en gammel regnskapsprotokoll funnet på loftet til kårbygningen på garden Elton. Protokollen var fort av Jens Bjerknes (1835-1901) som var gardbruker og "propiertar" på Elton ovenfor Raufoss.

Protokollen viser seg nemlig å inneholde "Fyrstik-Fabrikkens Regnskab" fra 27. juni 1873 til 15. september 1875. Dette dekker 38 sider. Lenger ut i protokollen er det ført regnskap for Elton for tidsrommet 1889-1900.

Jens Bjerknes var født i Fåberg, utdannet agronom, og kom til Vestre Toten i 1862 som bestyrer ved Lerudmyra interessentskap. Han kjøpte like etterpå garden Elton og var med i interessentskapet som i 1868 kjøpte Rødfossen gard. Dette selskapet bestod av forretningsfolk og bønder på Toten, Vardal og Gjøvik og drev særlig aktivt saga ved Rødfos Brug sammen med oppkjøp av skogeiendommer. I 1872 solgte interessentselskapet ved Jens Bjerknes Rødfossen til Martin Hveem på Smeby. Men allerede året etter selger Martin Hveem Rødfos gard til interessentselskapet Rødfos Fyrstikkfabrik ved Jens Bjerknes.

Ideen om å anlegge en fyrstikkfabrikk på Raufoss må altså ha kommet i 1873, og Jens Bjerknes som også var med i interessentselskapet fra 1868 er formann i styret for fyrstikkfabrikken og nokså sikkert en drivkraft bak prosjektet.
Mens interesssentselskapet fra 1868 hadde en forholdsvis liten aksjekapital fordelt på lokale hender, er aksjekapitalen i fyrstikkfabrikk-selskapet på hele 30.000 spesiedaler. En kapital som nok i hovedsak var hentet utenfor distriktet ettersom styremedlemmene utenom Bjerknes var hoffapoteker Hans S. Ditten, overrettssakfører Wilhelm Faye-Hansen, grosserer Gustav Christian Hellesen og hypotekbanksekretær Bernt Th. Paulsen.

Protokollen som har dukket opp følger aktiviteten med oppbyggingen av fabrikken fra høsten 1873 og fram til den var driftsklar to år etterpå.

Den første innførselen er fra 27. juni 1873: "Udlagt paa en Reise til Kristiania 5 Spd.", Jens Bjerknes hadde altså møtt styremedlemmene og investorene i Kristiania, der de sikkert hadde gjennomdrøftet hvordan oppbygningen av fabrikkanlegget skulle skje. Byggeprosessen startet nærmest umiddelbart, for den 17. juli utbetaler Bjerknes 6 spesidaler til Jens Knudsen "contant paa Gjøvik, paa Stenbrydningen". Den 22. august er Jens Knudsen igang "i Rødfossen" da han făr de neste 5 
spd., og fram til 7. mars 1874 fikk han totalt utbetalt 56 spd. Jens Knudsen brøt nokså sikkert gråsteinen til fabrikkmurene, og ut fra en omtrentlig beregning basert på lønnsnivået som er nevnt ellers i protokollen med 3 eller 4 ort pr. dag, kan vi regne med at Knudsen her fikk betalt for omlag 14 ukeverk. Det var $i$ et steinbrudd oppe ved Karsrudskogen steinen ble tatt, og sjøl om fyrstikkfabrikken er borte i dag, står de metertykke gråsteinsmurene ennå $\mathrm{i}$ en av fabrikkbygningene på Raufoss A/S. Ettersom det blir mye snakk om spesiedaler, ort og skilling i artikkelen, tar vi med at pengesystemet i Norge i 1816-1875 var bygd på at 1 spesiedaler rommet 5 ort, og at det i 1 ort var 24 skilling.

Det neste Jens Bjerknes gjør er å reise til Stavsmarken på Tretten i Gudbrandsdalen der han kjøper to hester. Han betaler dyrlege Plein 1 spd. "fordi han var behjelpelig ved Hestekjøbet", så han tok altså ingen sjanse på å få dårlige hester. Og hestekjøpet var heller ikke billig - den ene hesten ble kjøpt av J. Biessum fra Våga for 160 spd. og den andre fra Hans Stubberud i Fron for 135 spd. Jens Bjerknes kjøpte også med seletøy av A. Balling i Fåberg, og seinere kjøpte han en arbeidskjerre, en arbeidssele, en hjulslede og to "Træe Juel til en Vaagn" til hestene.

\section{Civilingeniør Adam Collin}

Ut fra regnskapsboka ser det ut til at Jens Bjerknes fikk assistanse fra og med l. september 1873 da navnet Collin dukker opp for første gang. Han ankommer til Raufoss fra Kristiania, ettersom det står i protokollen at han har "Medtaget fra Hansen" (fra overrettssakfører Faye-Hansen) et større pengebeløp. Samme dag fører Bjerknes 1 spd. til utgift "For denne Protokoll" og 8 skilling "For en Post- bog til Collin". Sivilingeniør Adam Collin var ansatt for å ha ledelsen av oppbygging og idriftssettelse av fabrikken og skulle vel bli bestyrer etter idriftssettelsen. Da firmaet meldte seg til handelsregisteret 25. januar 1875 er nemlig Collin kalt bestyrer. Regnskapsprotokollen viser at Collin ledet oppbygningen av fabrikken, og gjennom 1873, 1874 og våren 1875 er store og mindre beløp stadig utbetalt gjennom Collin. Den 14. april 1875 står imidlertid Collin nevnt for siste gang, og da har Bjerknes ikke bare skrevet "Collin" som oftest før, men "Udbetalt Hr. Ing. Collin contant 45 spd." Regnskapsboka tyder altså på at Collin og Bjerknes skilte lag her, og da flere måneder før fabrikken var ferdig. Collin ble forresten seinere statsingeniør i Kristiansand.

\section{BYggematerialeR}

Allerede 3. september 1873 leser vi "Udlagt paa en Reise til Teterud, Sund, Gamme og Østgaardshagen i Anledning forskjellige Indkjøb 1 ort 18 sk." Den 12. september reiser han med "egen Hest fra Elton til Qvernum," og den 16. sept. betaler han C. Blaavarp og A. Qvernum vel 163 spd. for "82 Tylter Topstammer" og for 26 bjelker.

Dette var materialer som sannsynligvis skulle brukes til bjelkelag og takkonstruksjon på fabrikkbygningen. Muligens kom tømmeret fra Teiterud eller Sund og med C. Blaavarp og A. Overnum som mellommenn. Dette fordi tømmeret tydeligvis ble fløytet på fjorden. Den 17. sept. 1873 skriver Bjerknes: "Emil Vadet for at ro en Tømmergrime 1 Spd." Det var også lønn til Anton Blaavarp, Nikolai Blåvarp, Tommas Blaavarpeie, Mathias Qvernum, O. C. Qvernum og P. Fiskevolden. P. Fiskevolden fikk dessuten 60 skil- 
ling for å frakte lensen tilbake. Bjerknes la også ut 1 spd. ved sin "Nærværelse i Brøtningen."

En fast regel ved tømmerfløtning i Hunnselva var at fløterne hadde med seg rikelig med brennevin. En måtte stadig vekk ut i det iskalde vannet, og brennevinet var det eneste som kunne gi varme i krøppen. Og i regnskapsboka her kan vi også avlese dette på neste dag:

18. For Expres til Gjøvik —-18

-»-10 Potter, Brendevin 2-20

-»- Expres til Fiskevolden -2-

I tillegg er det ført 12 skilling som ekstra utgift til P. Fiskevolden. Det var blitt bygd demning ved Fiskevollen i 1871, og fløytinga startet derfor derfra.

Ellers kjøpes det stadig trematerialer - sagbord, to toms planke og tømmer. Den 29. april 1874 får Kristian Blåvarp utbetalt 102 spd, 1 ort 18 skilling for 97 tømmer og 5 skippund ulesket kalk og 7 tønner og 7 skippund lesket kalk. Dette var nokså sikkert kalk til gråsteinsmuringen. Denne handelen må vel også sees i sammenheng med reisen: "I Anledning forskjellige Indkjøb" som Bjerknes gjorde 3. september 1873, og der han besøkte Gamme og Østgaardshagen. Der var det jo kalkovner. I april 1875 fikk Anton P. Hagesveen gjennom Hans H. Gamengen utbetalt vel 10 spd. som restbetaling for kalk.

Teglstein ble kjøpt av Jens Mengshol (Ringsaker), først 10.000 stein i juli 1874, så 5.660 stein i juli 1875. Denne steinen ble sikkert brukt til pipemuring, - i fabrikkbygningen 1874 og piper til arbeiderboligene i 1875.

Den nye hovedbygningen på Raufoss gård som skulle være bestyrerbolig og kontor, skal være bygget i 1874 . Det er vanskelig å presist identifisere den i regnskapsboka. Den 18. august i 1874 blir det imidlertid utbetalt nesten 400 spd. til J. Linnerud i Vardal for kjøpt tømmer. A. Prøven som er byggmester Andreas Prøven (1832-1905), fikk utbetalt 50 spd. 29. oktober. Noe av det siste som skjer i 1875 før hele anlegget skulle være ferdig er imidlertid kjøpet av 7 ruller tapet 25 . august 1875. Det er vanskelig å tenke seg at tapeten skulle brukes noe annet sted enn i hovedbygningen på Raufoss gård.

\section{Arbeiderboligene}

Regnskapsboka viser at fabrikkbygningen ble bygget først, og antakelig dernest den nye hovedbygningen på Raufoss gård. Men hvor skulle arbeiderne bo når fabrikken skulle starte opp?

Den 14. april 1875 har Jens Bjerknes imidlertid bokført en utgift på 160 spd: "Udbetalt Ole L. Undlien for den af ham kjøbte Stuebygning." Og samme dag: "Udbetalt Ole Undlien for kjørt 5 Las af Bygningen a 3 ort." To dager etterpå får Ole J. Fæstadsæter, Carl Buer, Nils Olsby, Peder A. Berjer, Johannes Vallesæter og Ole Alfstadsæter oppgjør "for, kjørt af den i Undlien kjøbte Bygning”.

I alt kjørte de 225 stokker og 4 lass med rajer. Byggmester Andreas Prøven fikk samme dag utbetalt 20 spd. Så han ledet nokså sikkert nedtakingen og gjenoppbyggingen av bygningen.

En måned senere, den 14. mai, utbetaler Bjerknes så 70 spd. til Ole J. Lae "paa den af ham kjøbte Bygning”. Ole J. Lae hadde garden Bjørnerud på Eina 1871-77, og den 19. juli får han $280 \mathrm{spd}$. "paa den kjøbte bygning”. Det første beløpet fikk han sikkert da avtalen om kjøp ble inngått, resten da bygningen ble levert.

Mens bygningen fra Undlien ble kjørt på 
et par dager av 6-7 av bøndene i Veståsen, finner en ingenting i regnskapsboka om kjøring av Bjørnerudbygningen. Derimot kan vi lese på den 23 . juli 1875 , altså 4 dager etter bygningen ble betalt: "Udbetalt Petter Olsen Elvepasser for Flødning 7 spd. 16 sk".

Her er det sjølsagt et viktig poeng at Undlienbygningen ble flyttet $\mathrm{i}$ april mens det var sledeføre, - Bjørnerudbygningen midt på sommeren. Sommerstid ville det vært en fryktelig jobb å kjøre alt bygningstømmeret på de elendige vegstubbene helt ute fra midt på Einafjorden og til Raufoss. Det er derfor neppe noen tvil om at bygningen ble fløytet, først på Einafjorden og så i Hunnselva.

Disse bygningene ble oppsatt slik de hadde vært, men påbygd svalgang i to etasjer etter ene langveggen. Bygningene stod så med svalgangen mot hverandre og gardsplassen imellom. Den ene bygningen hadde 6 leiligheter, de andre 8 , alle på ett rom og kjøkken. Hver leilighet hadde inngang fra svalgangen.

Noen år seinere ble det bygget en tredje arbeiderbolig vest for den nordre boligen. Alle ble revet omkring 1970 da det nye stålstøperiet ble bygd på Raufoss. Den søndre boligen ble imidlertid bevart og flyttet til friluftsmuseet på Stenberg. Det er den med 6 leiligheter og altså den minste av de to eldste. $\mathrm{Og}$ ettersom Undlienbygningen ble betalt med mindre enn halvparten av det Bjørnerudbygningen kostet, er det sannsynligvis Undlienbygningen som nå står på Stenberg.

\section{ArbeidsstokKen}

\section{VED BYGGEARBEIDENE}

Den 19. september 1873 utbetales lønningene for den første arbeidsuka i byggeanlegget. Da er hver enkelt nevnt, seinere vises det bare til lønningslister og samlet sum. Daglønna varierer mellom 3 og 4 ort, det vil si ei ukelønn på omkring $4 \mathrm{spd}$.

Det er 21 mann som får lønn: P. Mjøberg, Johan Tostenstuen, Andreas Bjørneløkken, Andreas Dragvold, Matias Farver, Peder Berger, Hans Nilsen, Løurits Pedersen, Ole Nilsen, Kristian Napstad, Martin Negaard, Hans C. Grøthaug, Hans Rogsvolden, Andreas Rødfosengen, Hans Rødfossen, Ole Rødfossen, Ole J. Pedersveen, Lars Madsen, Ole Murer, Hans Prøven og Andreas Prøven.

Fram til april 1875 utbetaler Collin lønningene over sin kasse der han får overført runde summer fra Bjerknes. Deretter er kostnadene pr. uke spesifisert. Alt tyder på at det i hele perioden arbeidet 20-30 mann i anlegget.

Fast lønningsdag er onsdager. Og det var bra å ha arbeid på anlegget. Lønningene lå godt over det dobbelte av hva en f.eks. tjente som arbeider i jordbruket.

Den eneste som er nevnt som murermester er "Murmester Skinstad" som i november 1874 får 42 spd. "paa Murarbeid contant." $\mathrm{Da}$ er imidlertid selve fabrikkbygningen antakelig allerede forlengst under tak. Etter det som har vært fortalt var det Lars Madsen (f. 1835) som var bas for gråsteinsmurerne. Ettersom han er med fra starten i bygget og også nevnes flere ganger underveis er antakelig det rett.

Alt tyder også på at Andreas Prøven ledet trearbeiderne, og han er også med gjennom hele byggeperioden. Blikkenslager er Martin Martinsen Grøthaugeie. A. Elstad og Anders Lisødegaard har tilsammen $15 \mathrm{spd}$. for "Tinarbeide". E. Narum gjør «Rørarbeide», mens "Bluncks Rørlæggere" blir skysset til Dal stasjon i Eidsvoll i august 1875 like før fabrikken var driftsklar. De hadde antakelig utført arbeid med klargjøring av maskinene, kanskje i forbindelse med rørføringer for damp. 
Den 18. november 1874 utbetales 50 spd. til "Architægt Aschenbach paa Gjøvik paa hans Tilkommende for Byggearbeide i Rødfossen." Tre uker seinere får han en "Rest" på 26 spd. J. C. C. Aschenbach var ikke arkitekt, men byggmester. Likevel er det grunn til å tro at når Jens Bjerknes kaller ham arkitekt så kan det skyldes at Aschenbach har gjort tegnings- og planleggingsarbeide i forbindelse med byggingen.

Johan Saugstad (f. 1826) var verksmester ved fyrstikkfabrikken etter idriftsettelsen. Han dukker opp i regnskapsboka første gang i oktober 1874. Da var muligens byggingen av fabrikkbygningen kommet så langt at maskiner og innredning stod for tur. Johan Saugstad var fra Fåberg og altså sambygding med Jens Bjerknes. Det er derfor nokså sikkert at han ble håndplukket til jobben av Bjerknes. Regnskapsboka viser at Saugstad har stor tillit, og etter at Collin blir borte våren 1875 er det Saugstad som tar over den praktiske administrering av arbeidene. 31. august 1875 får ”J. Saugstad udbetalt sin Maaneds Løn for August", og den var på 26 spd. I 1875 var det 26 hverdager i august, og han hadde derfor 1 spd om dagen, 25-50\% mer enn byggearbeiderne.

\section{SMEDSHAMMER}

Samtidig med at fyrstikkfabrikken var under oppføring gikk de "gamle" deler det som var Rødfos Værk sin gang. Det var mølla som Hans Møller drev samtidig som han hadde plassen Persvea. Og det var saga som Andreas Sagmester stod for. Hans Møller betalte 3 spd. $\mathrm{i}$ året for Persveen. Det var også to plasser Rødfossengen, - Kristian Engen betalte 8 spd. i avgift, Andreas Engen 2 spd. 2 ort og 12 skilling.
Men den største aktiviteten var knyttet til "Rødfos Liafabrik" på Smedshammer. Smedshammer var utskilt fra Raufoss gård i 1859 da svensken Ole Erikson anla ei stor ljåsmie. Et vasshjul drev tre vasshammere i smiebygningen.

I regnskapsboka finner vi Smedshammer nevnt første gang 14. oktober 1873: "Laant Smedshammer 1.500 spd." Det som skjedde her var at Rødfos Værk kjøpte tilbake Smedshammereiendommen fra Ole Erikson.

Jens Bjerknes har så den 14. november 3 skilling i utgift på ”Porto for et Brev til Ljåsmed P. A. Nordal.” Peder A. Nordal kom til Raufoss, han var fra Sverige i likhet med Ole Erikson. Det var plass til to familier i Smedshammer og Frantz C. Mjøberg, også svenske, ble den andre smeden.

Den 28. april 1874 ser vi at Jens Bjerknes skriver til August Lind et Co. i Stockholm og bestiller stål for $25 \mathrm{spd}$. Ellers er det vanskelig å få helt oversikt over omfanget av ljåproduksjonen ettersom en stor del av omsetningen ser ut til å ha foregått i et mellomregnskap med kjøpmann Skattum på Gjøvik. Den 3. juli 1874 er det bokført 4 spd. 2 ort 20 skilling for "1 Tylt Lier" med fradrag av 5\% som er solgt til J. Sørgendal. Dette gir 2 ort $(=2 / 5$ spd) pr. ljåblad.

1. juni 1875 reiser Jens Bjerknes til Kristiania og den 14 . juni har han notert i regnskapsboka: "Til Kjøbmand F. Lønseth Grendsen i Kristiania 40 a 50 Tylter Liaer hvoraf omtrent 1/3 Deel av 4 1/2 (kvart)Al. Resten 5 q og 1 a 2 Tylter 4 q. Liaerne leveres paa samme Betingelse til Lønseth som til Skattum med 5\%." Ljåene ble altså levert i tre ulike lengder regnet i kvarte alen. Bjerknes skriver videre at han direkte leverte 1 tylt, altså 12 stk. 5 kvart-alen ljåer. En bestilling på 600 ljåer var ikke dårlig! 
I juni 1875 ble det sendt ny bestilling til A. Lind i Stockholm på "2 Kasser Staal", igjen for $25 \mathrm{spd}$.

En annen viktig bestanddel i smievirksomheten var kull. Den 23. november 1874 kan vi lese: ”Kjøbt af J. Roset med flere 50 Lacter Kul leveret til Rødfos Liafabrik for 2 spd. 1 ort pr. Lact. Kullerne skal leveres inden 14de April 1875 saaledes: af J. Roset 17 Lacter, L. L. Roset 15 Lacter, Lars Chr. Roset 15 Lacter og af Johanes S. Roset 8 Lacter, tils. 50 Lacter." En lakt kull var et kubikkmål som tilsvarte omlag 3x3x1 alen, nokså akkurat 2 kubikkmeter. Om disse leveransene skjedde på denne måten ser vi ikke i regnskapsboka.

Lars L. Roseth får imidlertid påbetalt 20 spd. for kull den 17. april 1875. Den 28. april leverer han 12 1/2 lakt, Anton Andreassen Sørlien 3 1/2 lakt og den 5. mai leverer Lars L. Roseth ytterligere vel 17 lakter.

Den 30. juni 1875 får Ole Lerudeie ei daglønn for å ha skjeftet og dreiet "Slibestenene" ved Smedshammersmia. Samtidig har Johan Saugstad tatt imot 4 spd. 2 ort, 12 skilling for "Slibning af 750 Knivblader a 3 ort pr. 100”. Ljåproduksjonen krevde naturlig nok slipesteiner, som sannsynligvis også var drevet av vasshjulet. Og den store knivproduksjonen i V. Toten kunne dra nytte av dette anlegget. Ferdiggjøringen av knivbladene krevde også enda mer sliping enn ljåbladene. I juli som var neste måned kunne Saugstad ta inn nesten 8 spd. for "Knivbladslibning." Det vil si omkring 1.300 knivblader.

\section{AKSJOnÆREne}

Som nevnt foran var tyngdepunktet i eierinteressene utenfor distriktet. Mens Jens Bjerknes koordinerte aktiviteten på Raufoss og oppbyggingen av den nye fabrikken, er det overrettssakfører Wilhelm Faye-Hansen som

synes å koordinere interessene til investorene i Kristiania. Han oversender hver måned et større beløp til Bjerknes, og det er i hovedsak disponeringen av disse pengene regnskapsboka viser. I alt sender Faye-Hansen 22.143 spd. til Bjerknes i løpet av de to årene.

Men Bjerknes tok imot innbetalingen av aksjekapitalen fra de lokale aksjeeierne direkte. De ser ut til å ha innbetalt sine andeler i 5 terminer, totalt 1.600 spd. Kjøpmann Skattum på Gjøvik skjøt inn 100 spd, sivilingeniør Adam Collin 500 spd, David Øfstaas, bonde på Bøverbru, 200 spd, Martin Morterud som var landhandler, 200 spd., O. C. Præstesæter, bonde på Reinsvoll 20 spd., Johan Braastad, Vardal, 100 spd., Peder Adolf Lie, gardbruker på Lie, 100 spd. og til sist Jens Bjerknes sjøl som hadde aksjer for 200 spd. Dette var det som var innbetalt i 5 terminer. Hvis innbetaling skjedde også etter 1. sept. 1875, var den lokale kapital større.

Hadde Bjerknes for mange penger liggende, satte han de inn på Gjøvik, enten i Holmen Brenneri eller hos kjøpmann Skattum. Dette ga 4\% innskuddsrente. Var kassa helt tom, måtte Bjerknes låne. Den 13. mai 1875 "Modtaget et Laan af O. C. Præstesæter" på 800 spd., og den 7. juni låner han 200 spd. av Martin Indahl og samme beløp av Ole F. Flikkeshaug. For lånene er det 5\% rente. Først i 1876 innledet Rødfos Værk kontakt med Totens Sparebank, da ved å låne 700 spd. Da var imidlertid O. C. Præstesæter blitt bankkasserer, så det som skjedde var vel kanskje at restbeløpet på de 800 spd. han hadde lånt ut ble gjort om til lån i sparebanken.

For sitt arbeid med administreringen av oppbyggingen av fyrstikk-fabrikken mottok Bjerknes 300 spd. som "det Tilkommende Honorar". De siste 50 spd. tok han ut 31 . 
10 august 1875, dagen før han overlot fabrikken til den nye bestyreren.

\section{"Pigerne fra Jølsen"}

Sommeren 1875 begynte fabrikkanlegget å ta form. Men hvordan ville det være å starte opp en så spesiell industriproduksjon i et område der de færreste noensinne hadde sett en fabrikk?

Bjerknes sjøl måtte også lære om produksjonen og skaffe seg kontakter. Den 14. juni 1875 skriver han i regnskapsboka: "Udlagt paa en Reise til Kristiania om Nittedalen og Enebak for Diet i 7 Dage og Skyds." Utgiftene var på 12 spd. og 3 ort. Nitedals Tændstikfabrik som Bjerknes besøkte var en av landets største fyrstikkfabrikker. I Enebakk lå proprietær Holm Jølsens fyrstikkfabrikk.

En måned seinere er Bjerknes igjen på farten, og han bokfører 11 spd. 2 ort og 8 sk. den 19. juli som "Udlæg paa en Reise til Kristiania og 2 Reiser til Jølsens Fyrstikfabrik."

Resultatene fra denne reisevirksomheten viser seg 10 dager seinere da Bjerknes utbetalte 3 spd. til Amund Olsen og "Pigerne fra Jølsen paa Arbeide."

Først i august utbetales det så 21 spd. til H. Jølsen før "hans Udlæg til de hidsendte Arbeidere." Det blir også utbetalt nær 3 spd. i slutten av august til E. Forberg "for Nattelogi m.m." for arbeiderne fra Jølsen.

Hvorfor så stor vekt på å få tak i disse "Pigerne fra Jølsen"? Jo, størstedelen av de ansatte i en slik fyrstikkfabrikk var kvinner. Og det var på pakkeriet de var sysselsatt. $\AA$ få til en effektiv drift her var en absolutt nødvendighet. Antakelig kunne heller ikke noen av mennene som satte igang fabrikken å pakke fyrstikker!

Den 31. desember 1875 ble det holdt fol- ketelling. Og der ser vi da også hvem "Pigerne fra Jølsen" var. I ei av leilighetene i arbeiderboligene bodde nemlig de tre ugifte jentene Johanne Marie Johannessen, 19 år, Gunhild Amundsen, 24 år og Karen Bergithe Amundsen, 19 år. I tillegg var Olaus Edvartsen, 19 år, også kommet til Raufoss fra Enebakk. De andre arbeiderne var født på Toten, Hedemarken og i Valdres.

\section{OsPEKJØP}

Ved siden av tilgangen på arbeidskraft, og vannkraften i Raufossen, var ospevirke den viktigste lokale ressurs for fabrikkdriften. Allerede med en gang byggingen av fabrikken starter i 1873 er Jens Bjerknes igang med å sikre seg nok osp. Den 20. oktober 1873 leser vi: "Betalt Peder O. Steffensrud for den ifølge Kjøbekontragt af 15de Kjøbte Asp 63 spd."

Dagen etter fører Bjerknes 1 ort som "Udlagt paa en reise i Anledning Indkjøb af Asp i 2 Dage." Og samme dag påbetaler han $5 \mathrm{da}$ ler hver til Kristian Larsen Hexum og Peder C. Hexum for osp.

Utover i november og desember 1873 gjør Bjerknes flere slike avtaler med forskuddsbetaling. Likeens vinteren 1874, da for levering høsten 1874.

Ospa ble levert i 4 eller 5 aleners lengder, målt i favner. 17. april 1875 leverer Ole Amundsen Bjugstad "1/2 Favn 5 Al. Asp a 3 ort 12 sk." For dette fikk han 7 spd. Det viser at det ble betalt 84 skilling pr. kvart alen av favnen. Og en pris på 14 spd. for en favn var en god pris.

Ettersom ospevirket levert i 1874 bare ble liggende, og det ble gjort nye innkjøp i 1875 , må det ha vært en anselig mengde osp på lager da produksjonen startet høsten 1875. Men 
det skulle også til, - fra ospeveden ble det laget både stikker og fyrstikkesker.

\section{FABRIKKEN ER FERDIG}

I månedsskiftet juli-august 1875 begynner brikkene å falle på plass. Fabrikkbygningen er ferdig, råvarene ligger der, spesialarbeiderne er ankommet og arbeiderboligene er i ferd med å bli klare.

Den 29. juli er noe på gang, for da kjøper Bjerknes 100 frimerker, 2 ris med papir og betaler 2 spd. 3 ort til "Bogtrykker Christen for Trykning efter Regning". Boktrykkeren var Jens Chr. Christensen (f. 1827) som siden 1860 utga "Kristians Amtstidende" på Gjøvik. Hva Bjerknes sendte ut vet vi ikke, men det hadde nok sikkert noe å gjøre med den nær forestående oppstarten av fabrikken.

Den 4. august får lensmann Bratli betaling for to takstforretninger, - en over fabrikkbygningen med tilstøtende materialbod i bindingsverk, og en over maskinene. Dette var i Norges Brandkasse. De andre bygningene, altså arbeiderboligene og gardhusa, ble forsikret i Toten og Vardals Brandkasse ved takst samme dag.

Tre uker seinere betaler Bjerknes "for et Avertissement" i avisene Almuevennen, Verdens Gang og Morgenposten. Han betaler også 16 skilling til "Lensmand Bratli for en Bekjendtgjørelse fra Kirkebakken”. Dette siste var altså ved Aas kirke, og vi må regne med at det var samme kunngjøring i avisene som det lensmannen offentliggjorde fra kirkebakken. Kanskje var det meldingen om at fabrikken nå skulle starte opp. Det er jo mulig å finne ut dette ved å gå tilbake til avisårgangene fra 1875. At Bjerknes ikke averterte i lokalavisene i Oppland, men brukte lensmannen til å kunngjøre, knytter seg sjølsagt til det faktum at svært få den gang holdt disse avisene.

Den 20. august 1875 utbetaler Bjerknes 3 ort 16 skilling til "Madame Saugstad for Kost til en Mekkanikker i 1 1/2 dag og for inkjøbt Sæbe m.m." Nå ble antakelig dampmaskineriet igangkjørt, og den 31. august avslutter Berknes føringen av regnskapsboka.

Etter dette er det bare to posteringer; den 8. og den 15. september, begge lyder "Udbetalt Lange", og det var tilsammen ca. 260 spd. Lange det var Otto Wincent Lange (f. 1848) opprinnelig fra Tromsø, som nå vil vi tro med oppstart den 1. september 1875 var ansatt som bestyrer for fyrstikkfabrikken. To års byggevirksomhet og forberedelser var over, og styreformann Jens Bjerknes kunne overlate fabrikken med daglig drift og regnskapsføring til Otto W. Lange.

Note

- Texten hämtad ur: TOTN. Årbok 1988, s. 107117 (Gjøvik 1988). 
Nordisk Museologi 200I • I-2, S. I2-I8

\title{
INGEN LEK, MEN ARBEID OG SLIT!
}

\section{Industrielt barnearbeid på Raufoss 1875-1895}

\author{
John Aage Gjestrum
}

\begin{abstract}
"Barneåra husker jeg som arbeid og slit, men ingen lek". Slik mintes Karoline Løkken (f. 1879) sin oppvekst på Raufoss i 1880 åra. På Raufoss var "Rødfos Tandstikfabrik" blitt satt i drift i 1875 med 53 faste arbeidere og 50 barn sittende hjemme à lime fyrstikkesker. ${ }^{1}$
\end{abstract}

Av de faste arbeiderne var i 1875 også 7 under 15 år, slik at barna da utgjorde 55\% av fabrikkens samlede arbeidsstokk. ${ }^{2}$ Vi skal i denne artikkelen forsøke å gi et bilde av det industrielle barnearbeidet slik det artet seg på det nye industristedet Raufoss de siste 10-åra av 1800 -tallet. Innledningsvis skal vi igjen gi ordet til Karoline Løkken:

Vi barna ble satt til hjemmearbeide for fyrstikkfabrikken fra vi var 3-4 år. Vi laget "esker og trysker". Vi fikk utlevert spon, klister og etiketter fra fabrikken. Betalingen var 20 øre for 1.000 trysker og 25 øre for 1.000 esker. Å lave 1.000 var arbeide for 3 små i en hel uke. 6 år gammel begynte jeg på fabrikken, og hadde heldagsarbeide hver annen dag. Men ogsaå de andre dagene da vi hadde skolegang måtte vi møte opp på fabrikken etter at vi hadde spist middag. Det første året var jeg med og hjalp far, men fra jeg var 7 år begynte jeg $\mathrm{i}$ pakkeriet. På heldagsarbeide kunne jeg greie å pakke inntil 8 gross, på skoledager 3 gross. Betalingen var 6 øre pr. gross. Som 12-14 åring var jeg oppe i 10-12 gross, etter 16 års alderen kunne jeg greie 100 gross og mere. Til å begynne med betalte jeg kr. 1.50 for uken hjemme, senere 3 kroner. Det ble lagt tilside penger så jeg hadde til konfirmasjonsklær. ${ }^{3}$

Det er en hel rekke spørsmal vi gjerne vil finne svar på når vi tar opp det industrielle barnearbeidet. Noen har vi allerede berørt: Hva slags arbeid hadde barna? Når begynte de med fabrikkarbeidet? Var barnearbeidet skadelig? Hvor mye arbeidet barna? Hvem fikk lønna? Hvorfor fikk vi et så omfattende industrielt barnearbeid? Hvilke holdninger var det i samfunnet til dette barnearbeidet?

Nå, hundre år etterpå er det vanskelig å finne dokumentasjon som kan kaste fullt Iys over de spørsmål vi ville finne svar på. Ei hovedkilde er 5 beretninger samlet inn i den store arbeiderminneinnsamlingen Norsk Folkemuseum drev i 1950-åra. Ei anna viktig kilde er folketellingene i 1875 og 1891.

\section{HovedTREKK}

VED FYRSTIKKFABRIKASJONEN

For å forstå barnearbeidets plass i bildet, må 
vi kort ta for oss hovedtrekkene ved fyrstikkfabrikasjonen slik den var på Raufoss. Ospetømmer utgjorde hovedråstoffet. Det ble kappet i kubber på $40 \mathrm{~cm}$. lengde. Etter at de var dampet opp, ble de tatt inn i fabrikkens spondreieri hvor ei maskin dreide spon til stikker, og ei anna dreide eskespon. Ei karvemaskin karvet spona til stikker. Eskespona ble så sendt ut på bygda til hjemmearbeid. I midten av 1880-åra ble det maskiner som lagde skuffer og trysker, og hjemmearbeidet tok slutt. Stikkene ble tørket og lagt i ramleggermaskiner, som ordnet stikkene i rammer. Hver ramme ble sa dyppet i ei panne med flytende svovel og overstrøket med fosfor. Dette var den farligste del av produksjonen, og tok det fyr i ei ramme med fyrstikker, måtte en være snar å få kastet den ut av bygningen. Hele tre ganger brant Rødfos Fyrstikfabrik ned på de 20 åra den var i virksomhet.

Når fyrstikkene var tørket, gikk de til pakkeriet. Pakkeriet kunne beskjeftige opp til100 arbeidere, og det var her flesteparten av barna og kvinnene arbeidet. Eskene ble her fylt med stikker. De gikk så videre til sanderiet, der lim og sand ble paført riveflaten. Etterpå gikk eskene til grosseriet der de ble pakket dusinvis, for siden å bli pakket i hele eller halve gross. Til slutt ble pakkene lagt i trekasser med innvendig igjenloddet sinkkasse. ${ }^{4}$

\section{HVA SLAGS ARBEID HADDE BARNA? \\ NÅR BEGYNTE DE \\ MED FABRIKKARBEIDET?}

Foran har vi sitert fra hva Karoline Løkken kunne fortelle. Hun begynte allerede som 34-åring sammen med søsknene å lime esker og trysker, mens hun som 6-åring begynte på selve fabrikken, då sammen med faren. 7 år gammel arbeidet hun alene på pakkeriet. I
1875 bodde bare 9 av de 50 barna som laget esker på selve Raufoss. Den yngste av disse 9 var Mateas Andreassen som var 6 år gammel. De andre er fra 7-9 år, med unntak av ei jente på 13 år. ${ }^{5}$ Resten av barna som gjorde esker bodde så utover hele bygda, helt ut til ytterst i Kolbu og Eina. ${ }^{6}$ Anna Løvstad (f. 1873) var et av disse barna, og vi skal høre hvordan hun opplevde eskearbeidet:

Fra jeg var 8-9 år hadde vi hjemmearbeide fra Rødfos Fyrstikfabrik, som lå fra 6 til $7 \mathrm{~km}$. fra der vi bodde. Vi hentet spon, etiketter og klister (rugmel) på fabrikken. Mor fulgte meg de gangene hun kunne, men som oftest måtte jeg gå alene. Vinterstid hadde jeg kjelke og om sommeren en slags kjerre, men tungt var det for spona skulle være myk og var dampet, så den var rå. Betalingen var 25 øre for 1.000 esker og 20 øre for 1.000 trysker. Jeg kunne sammen med en yngre bror greie fra 1.000 til 1.500 stk. på en dag.

Men moren var enke, og hun livnærte seg derfor ved å gå rundt på gardene i slakting, flatbrødbaking, vasking o.l. Dette gjorde at det ble enda mer på vesle Anna:

Da mor stadig måtte være borte, var det jeg som hadde stellet hjemme ved siden av hjemmearbeidet for fyrstikkfabrikken. Jeg gikk på Sagvoll skole, i førstningen 2 , senere 3 dager i uken. På skoledagene ble det mer arbeide enn ellers, for da ventet alt «stellet» på meg når jeg kom hjem? .

Barna som kom i arbeid i selve fabrikkbygningen kom helst på pakkeriet. Folketellingen i 1875 bruker her bare benevnelsen "fabrikarbeider" (eller "fabrikarbeiderske") på barna i fabrikken. I 1891 står det derimot anført hva den enkelte gjør. Av 19 barn bosatt på selve Raufoss som da arbeidet på fabrikken, var 15 på pakkeriet. ${ }^{8}$ Vi har statistikk over hele arbeidsstokken i $1890^{\circ}$, og den så slik ut: 


\begin{tabular}{rr} 
Menn & Kvinner \\
36 & 47 \\
8 & 26 \\
3 & 14 \\
12 & $\underline{11}$ \\
\hline 59 & 98
\end{tabular}

Det var altsa i alt 157 arbeidere, og 40 av disse var under 15 år. Vi må derfor anta at flesteparten av disse 40 barna arbeidet på pakkeriet. Ei av de vi ser arbeidet på pakkeriet i 1891 var den da 10 år gamle Marie Pettersen. Hun forteller:

Jeg begynte i fyrstikkfabrikken da jeg var 9 år. Jeg pakket fyrstikker i esker. Under pakkingen av fosforstikker var det ikke til å unngå at noen ble forgiftet i tennene eller kjeven, og måtte da ha en operasjon. Etter den ble de ofte skjeve i munnpartiet. Vi hadde en lege og en tannlege til å se over tennene, det var dr. Markussen og tannlege Skrettingland, begge fra Gjøvik. ${ }^{10}$

Anna Løvstad, som vi møtte foran, begynte på pakkeriet i 14-års alderen:

Jeg arbeidet også en tid i pakkeriet. Det var et helsefarlig arbeide på grunn av fosforet, og jeg vet om en 4-5 av mine arbeidskamerater som ble forgiftet i tennene og måtte opereres. Alle fikk varige men, de ble skjeve i ansiktet. Når en slik måtte være borte fra arbeidet, fikk en ingen erstatning fra bedriften. ${ }^{11}$

Karoline Løkken husket også dette:

På fabrikken hendte det ofte at noen ble fosforforgiftet, oftest i tennene. Måtte så en tann trekkes, fikk vi beskjed om å holde oss hjemme i 6 uker uten noen betaling. ${ }^{12}$

Fosforforgiftningen var en kronisk forgiftning som opptrådte ved hull i tennene. Kjevebeinet hovnet opp, og avsondret materie måtte fjernes ved utstrakte operasjoner. Fosfordam- pen forårsaket altså dette, og vi kan neppe i dag forstå den frykt arbeiderne måtte ha for denne sjuken. Helene Karine Thomassen (f. 1870) forteller om dette:

Skeive og skakke av "fosforsjuken" ble de fleste, de trodde at dampen gikk opp gjennom hull i tennene, ja, tannlege visste vi jo ikke hva var. Far fikk sjuken da han røsket ut en tann, han reiste opp og ned til Rikshospitalet i fem år før han døde.

Faren, Torger Kyseth, var da også den i fabrikken som hadde ansvaret for å veie opp og male til svovel og fosfor til produksjonen. Han var derfor særlig utsatt. Helene Karine Thomassen som fra hun var liten arbeidet på pakkeriet, forteller videre:

Nå var far så redd for mor i fosfordampen, og så fikk han fridd henne fra det ved at hun tok folk i kosten.

Da jeg var 18 år så døde far, og jeg fikk sjuken også. Så begynte jeg å hjelpe i kokinga, for mor var trøtt nå, og ved siden sydde jeg busseruller, for det var det bruk for. ${ }^{13}$

\section{HVOR MYE ARBEIDET BARNA? \\ HVA FIKK DE I LØNN OG HVEM DISPONERTE LØNNA?}

Arbeidstida var 10 timer pr. dag med tre hvilepauser. Men ofte ble det 12 timer uten noe ekstra betaling. Vi arbeidet også til 17.00 og 18.00 lørdag. Mor disponerte fortjenesten vår, dog fikk vi 30 øre hver 14. dag til eget bruk. Selv var jeg da 8-9 år. Vi stod 2-3 stykker ved siden av mor i arbeidet. Hver 14. dags lønning dreide seg da om 17 til 18 kroner. Fra 15-års alderen begynte jeg å få egen lønning. I begynnelsen tjente jeg 6 til 7 kroner pr. 14. dag, som økte til kr. 1,25 pr. dag da jeg var 19 år. Lønna utbetaltes en tid kun på anvisning lydende på fabrikkens landhandleri, senere det halve i penger, resten på anvisning, men til slutt i ren kontantlønn. I lønna det ble trukket 10 øre pr. uke i 
sykekasse, som betalte legen. Men fikk du en uhelbredelig sykdom ble du strøket som medlem. ${ }^{14}$

Slik husket Ole Hamar (f. 1876) forholdene omkring lønn og arbeidstid. Marie Pettersen (f. 1879) forteller det slik:

Fra jeg var 9 år till2 år var arbeidstiden fra kl. 7.00 til19.00 med halv time frokost, en time middag og en halv time eftasværd. Men da loven om barnearbeid kom, ble det 6 timers dag. De første åra tjente jeg 3-4 kroner uka. Vi måtte også møte opp på fabrikken etter endt skoledag. Hele familien arbeidet ved fyrstikkfabrikken ettersom de vokste til. Ved loven om barnearbeide var det mange som fikk det vanskelig når barna ikke kunne hjelpe til med å tjene penger. ${ }^{15}$

"Mine foreldre fikk alltid min lønn", ${ }^{16}$ forteller Alfred Larsen (f. 1879), og han kunne som 9-åring tjene 40 øre dagen på pakkeriet, noe mer ved overtid. Han forteller også om de samme arbeidstidene som de to foregående, altså en arbeidsdag på 12 timer inkludert tilsammen to timers kvile. Alt tyder på at barna her hadde samme arbeidstid som de voksne. Da barna så måtte arbeide også om ettermiddagen på skoledagene, skjønner vi at skolegangen måtte bli så som så. ”Jeg gikk 5 år på folkeskole, en tid to, men meste tiden tre ganger i uken", forteller Marie Pettersen. ${ }^{17}$ Når de i tillegg til å møte opp på skolen hadde omlag 50 timers hard arbeidsuke i fabrikken, kunne det ikke bli noe tid til lekselesning.

Lønnsnivået for barna ser ut til å ha ligget på mellom ca. 1/3-1/2 parten av en voksen arbeiders lønn. Hadde da samme familie flere barn i arbeid, er det klart at barnas lønning betydde mye for familiens økonomi. En av fortellerne nevner også at innskrenkningene som kom i barnearbeidet brakte flere i økonomiske vansker. Det viser hvor avhengige arbeiderfamiliene var av barnearbeidet.
HVILKE BARN ARBEIDET,
HVILKE IKKE? HVORFOR ET SLIKT OMFATTENDE BARNEARBEID?

Da fyrstikkfabrikken ble reist, ble det samtidig flyttet dit to gardbygninger som ble gjenreist til arbeiderboliger. I 1875 var alt klart, og Helene Karine Thomassen var 5 år gammel med blant de første som flyttet inn: "Far hadde vært med her fra første øksehogget i skauen, og da "boligene" var reist, hentet han mor og meg fra bygda. Vi fikk stue og kjøkken, .... og alle som bodde i bedriftens hus måtte lage fyrstikker, alle koner, og alle barn over 8 år." 18

Vi har ikke bevart noen kontrakter eller andre skriftlige kilder som sikkert kan dokumentere hvorvidt det virkelig var arbeidsplikt for barna over 8 år. Folketellingene kan imidlertid her gi visse holdepunkter. I 1875 bodde det $\mathrm{i}$ alt 55 personer $\mathrm{i}$ de to nye arbeiderboligene. 28 av disse var ugifte, enslige personer. De øvrige fordelte seg på 6 familier. Av disse er det bare ei kvinne som arbeider, nemlig Thine Larssen som er ugift mor med ei datter på 5 år. De gifte konene er derimot ikke ført opp som fabrikkarbeidere. Tre av dem har spebarn å ta seg av. Det er heller ikke usannsynlig at konene ellers hadde mye arbeid med å ha de enslige arbeiderne i kosten. I 1891 er dette særskilt nevnt i folketellingen, og dette var selvsagt et viktig bidrag til fabrikkdriftens opprettholdelse.

Ser vi på barna i 1875, er det i disse 6 familiene 10 barn over 8 år. Alle disse arbeider for fabrikken. ${ }^{19}$

I 1891 er det i alt 145 personer i 4 arbeiderboliger. 40 personer er enslige/losjerende, og de øvrige fordeler seg på 21 familier. 6 familier har kvinnelig eneforsørger. De andre 15 har alle mann i arbeid på fabrikken. 12 
16 koner arbeider ikke på fabrikken. 3 av dem tituleres spisevertinner og 4 husholdersker. Dette peker mot at de er engasjert i husholdningsoppgaver ut over familiens eget behov. I 1891 er 30 barn over 8 år i disse familiene fabrikkarbeidere. 5 barn over 8 år arbeider ikke pa fabrikken. Av disse er tre 9 år. $^{20}$

Folketellingene kan peke mot at det virkelig var arbeidsplikt for alle barn over 8 år i familier som bodde i fabrikkens boliger. Konene synes derimot å ha statt noe friere, ihvertfall så lenge de ville husholde for ugifte arbeidere og de tok seg av små barn. At barnas arbeidsplikt ble følt som temmelig hard, kan Helene Karine Thomassen fortelle:

Da jeg skulle gå for presten var vi i følge tre stykker til Åskjørken, ja det var drug veg. Vi gikk att og fram en gang i vikua, og på slutten to. $\mathrm{Og}$ når vi kom hematt om kvelden så stod de og ventet og skulle ha oss i fabrikken etterpå, men det orket vi ikke! Så satt vi i grøfta oppmed lina og ventet til det ble for seint, og så hinket vi inn ved brua og skyldte på gnagsåra. ${ }^{21}$

Men det er klart at langt flere barn enn de som bodde i fabrikkens boliger arbeidet for fabrikken. Fabrikkens press kan derfor neppe sies å ha vært eneste årsak til barnearbeidet. Under Rødfos gard var det i 18754 husmannsplasser. På "Rødfosbakken" bodde Kristian Kristoffersen. Han var husmann med jord og blikkenslager. Han har 5 barn; 13,11,9,7 og 4 år, og ingen av dem arbeider pa fabrikken, men forsørges av foreldrene. I "Rødfosengen" er Andreas Olsen husmann med jord. Han er i tillegg sagmester. Han har 6 barn: To på 15 og 11 år er fabrikkarbeidere. To på 8 og 6 år er eskearbeidere, mens de to minste på henholdsvis 2 og 1/2 år forsørges hjemme. Hans kone er imidlertid delvis fattigunderstøttet, antakelig på grunn av sjukdom. ${ }^{22}$ Barna må derfor arbeide for sin eksistens, noe som var den harde realitet for den fattigste delen av befolkningen. Det er også tydelig at de barna som ikke måtte arbeide på fabrikken av økonomiske eller boligmessige årsaker, de gjorde det heller ikke.

Når en spør hvorfor vi her fikk et så omfattende barnearbeid, så henger svaret svært mye sammen med det vi allerede har sagt. Hovedårsakene ligger selvsagt i det faktum at fyrstikkfabrikken på Raufoss i likhet med de øvrige fyrstikkfabrikker, så seg tjent med å bruke barn som arbeidskraft. Det var altså penger å tjene på å bruke barn framfor voksen arbeidskraft til visse oppgaver. Hadde ikke dette vært tilfelle, ville ikke fabrikken vært så ivrig etter å få barna i arbeid. Fyrstikkfabrikken som ofte balanserte på grensa til lønnsomhet, ville heller ikke ha råd til å sysselsette en hel mengde barn fordi barnas familier trengte barnas arbeidsinntekter for å få økonomien til å henge i hop. I stedet ble barnearbeidet et middel for fabrikken til å presse lønnsnivået ned for de voksne arbeiderne. En familiefar som kun skulle forsørge seg selv og eventuelt de minste barna, trengte ei mindre inntekt enn en som f.eks. skulle forsørge en hel familie.

Men da fabrikken først hadde åpnet portene for barna, er det klart at fattigdom og trang økonomi i mange familier var en nødvendig forutsetning for barnearbeidet. I sterk grad var det dette som avgjorde hvem som kom til å arbeide for fabrikken.

HVILKE HOLDNINGER VAR DET TIL BARNEARBEIDET? DET INDUSTRIELlE BARNEARBEIDS OPPHØR PA RAUFOSS

Barna selv opplevde nok barnearbeidet som noe naturlig, noe selvsagt. De vokste opp i fabrikkmiljøet, og eldre søsken og andre barn 
arbeidet jo også på fabrikken. På samme måten oppfattet nok foreldrene det, og folk i fabrikkmiljøet ellers.

Vi har ingen kjennskap til at det var noen opposisjon mot barnearbeidet på Raufoss. I 1889 brant fabrikken, og en innsender i lokalavisa "Samhold" peker på at skulle det bygges ny fabrikk, burde den produsere sikkerhetsstikker, ikke svovelstikker, og han skrev videre:

Hvad som mest beveger innsenderen til at skrive dette er at barna ved Rødfos Fyrstikfabrik skal sitte sammen med bygdas øvrige barn på skolen. Ja, tenk det at barna skal sitte og suge i seg den forferdelige gift. Det går ikke an lenger. Hvis det kommer fyrstikkfabrikk pa Rødfos, samme slags som før, må fabrikken bli nødt til å holde skole for sig selv. Det kan ikke nytte at sette op mot det. $^{23}$

Avisinnsenderen var altså mer redd for bygdebarna enn for fabrikkbarna!

På landsbasis ble imidlertid det industrielle barnearbeidet tatt opp allerede i 1875 , da Kirkedepartementet ba sekretæren i Statistisk Sentralbyrå utarbeide et lovforslag om "Børns og unge Menneskers Anvendelse til fast Arbeide udenfor Hjemmet." ${ }^{24}$ Det skulle gå lenge för dette arbeidet resulterte i noe, og det barnearbeidet vi har behandlet i denne artikkelen, skjedde nettopp i denne perioden. I 1892 ble det så vedtatt en fabrikktilsynslov som trådte i kraft i 1893. Alt industriarbeid for barn under 12 år ble forbudt, og barn mellom 12 og 14 år kunne bare arbeide opp til 6 timer pr. dag. Som vi tidligere har vært inne på ble dette møtte med motstand av foreldrene, da familiene på denne måten mistet viktige inntekter.

Det var ingen arbeiderbevegelse på Raufoss da, og derfor ble det de snevre perspektiver som preget arbeidernes holdning.

Ved Bryn og Grøndvold fyrstikkfabrikker kom fyrstikkarbeiderskene ut i streik i 1889, og redaktør Jeppesen i Social-Demokraten rettet da følgende kraftskyts mot den bruk eierne av fyrstikkfabrikkene gjorde av barn:

Saa Samvittighedsløse er de Folk, at de nu tager ind paa sine Fabriker Smaapiger og Smaagutter i otte til ti Aars Alderen. 20 saadanne Smaabørn havde de i forrige Uge faaet sammen. De lærer at pakke Fyrstikker. Når de blir rigtig øvede, kan de tjene mellem 1 a 2 Kroner om Ugen, og naar de har holdt paa med dette, lad os sige i 4 Aar, saa er de ødelagte for hele Livet. Hvad kan Fabrikeierne tjene paa en saadan Unge? 2 Kroner ugen vel. Det er 400 Kroner paa 4 Aar. Med andre Ord: For hvert 400 Kroner, som Fabrikeierne paa denne Maade bliver rigere, ødelægges et Menneskes Liv og Sundhed. ${ }^{25}$

På Raufoss ble fyrstikkfabrikken kjøpt av staten i 1895 for anleggelse av patronfabrikk. 1 . mai 1895 stengte fyrstikkfabrikken for godt, og bedriften som vi i dag kjenner som A/S Raufoss Ammunisjonsfabrikker tok over. En ny epoke tok til.

Helene Karine Thomassen så slik på minnene fra fyrstikkfabrikktida: "Nei, vi var vist ikke så bitre, for vi var uopplyste og trudde det måtte væra sånn! Og så var vi unge - og for ungdommen går alt." 26

\section{Noter}

- Artikkelen er tidligere gjengitt i Ophedia 1982. Här återgiven efter TOTN. Årbok 1988, s.118-126. (Gjøvik 1988)

1. Amtmannens 5-årsberetning 1871-75. Kristians Amt, s. 6.

2. Statsarkivet i Hamar (SA) Folketellingen 1875.

3. Arbeiderminnesamlingen, Hist. Inst. Universitetet i Trondheim. Arbeiderminner innsamlet på Raufoss ca. 1953 av L. T. Aas. Gjengitt i TOTN 1979 s. 38. 
John Aage Gjestrum

18 4. Avsnittet bygger pa L. T. Aas og Sigmund Kildal: "Fra Røefossen til Raufoss". TOTN 1974 s. 3842.

5. SA. folketellingen 1875 .

6. Aas og Kildal1974 s. 38.

7. Arbeiderminnene TOTN 1979 s. 44.

8. Riksarkivet (RA). Folketellingen 1891.

9. RA. Statistisk Centralbyra. Pakkearkivet B. 99.

10. Arbeiderminnene TOTN 1979 s. 41.

11. Ibid. s. 45.

12. Ibid. s. 38 .

13. Intervju ved Ingrid Arnulf. Gjengitt i Alle Kvinner 1954.

14. Arbeiderminnene TOTN 1979 s. 43.

15. Ibid. s. 41.

16. Ibid. s. 39.

17. Ibid. s. 41

18. Ingrid Arnulf 1954.

19. SA. Folketellingen 1875.

20. RA. Folketellingen 1891.

21. Ingrid Arnulf 1954.

22. SA. Folketellingen 1875.

23. Gjengitt i Aas og Kildal1974 s. 45-46.

24. Ingeborg Fløystad: "Vi lærte tidlig å arbeide.

Barnearbeid i Norge i de siste 200 år". I Forskningsnytt nr. 4/1979 s. 26-27.

25. Gjengitt i Gunnar Ousland: Fagorganisasjonen i Norge, bd. I (1949) s. 178.

26. Ingrid Arnulf 1954. 


\section{Petra Jensen bodde ”i Bolin"}

John Aage Gjestrum

Gjennom et oppslag i Oppland Arbeiderblad den 24. September 1977 sokte Toten Museum a komme i kontakt med personer som kunne hjelpe museet med innredning av "Bolig 241". Den er gjenreist på museet, men vi hadde lite informasjon om hvordan folk egentlig hadde det $i$ arbeiderboligene på Raufoss.

Den første som kontaktet museet etter oppslaget $i$ avisa var da 83-årige Petra Jensen ( $\mathrm{f}$. 1894) på Raufoss. Hun og mannen, elektriker Andreas Jensen, kom til Raufoss fra Kapp i 1916. Förste året på Raufoss fikk de leid ei leilighet i Roset (fig.1):

Vi hadde ett rom, og det var så lite at da vi satt ved kjøkkenbordet, så rakk vi bort på komfyren. Det var så langt at vi hadde akkurat plass til ei seng og åsså et lite kjøkkenbord nedafor. Der måtte vi ha vassbytter. Vi måtte bæra vatn lange veger. Om vinteren måtte vi bre snø. Je fekk en liten en tel i februar, og je bar snø tel all klutevasken. Vi måtte gå over 500 meter etter reinvatn.

Utpå seinhøstn 1917, altså for nøyaktig 60 år siden, var det blitt ledig ei leilighet i 2. etasje i den øverste arbeiderboligen (fig.2). Der fekk Andreas, Petra og to barn flytte inn. Petra forteller:

Da je kom dit, så syns je reint je kom inn i himmeln. Da vi kom inn i kjøkkenet der, så tørte itte han som kjørte fløttinga våres å gå inn på kjøkkengolvet, for da var det hele nymåle kjøkken. Det var så speilblank atte.

Leiligheta var på to rom på tilsammen ca. 30 $\mathrm{kvm}$. Det var stor forskjell fra det eine rommet i Roset. Her var det også innlagt både vann og elektrisitet. I denne boligen var det 8 leiligheter. De andre to boligene hadde 6 hver. Men ved at Petras leilighet var midt inni huset, kom sola aldri inn. Vinduet i stua vendte mot nord, mens vinduet i kjøkkenet vendte ut i svalgången: "At vi itte såg sola tenkte vi itte over. Det var jo denne lange verandaen, så vi gikk utpå der. Der hadde vi det koselig."

På grunnrissset over leiligheta kan vi se hvordan møbleringa var. Petra fikk sitt tredje barn "i bolin", og da søskenbarnet til Andreas begynte som handelsbetjent i samvirkelaget, så fikk han plass i dobbeltsenga på kjøkkenet. Mens det var $5 \mathrm{kr}$. i måneden for rommet i Roset, var det $3 \mathrm{kr}$. i boligen. Men Petra forteller:

Jeg er itte god for å kåmmå hau anna enn at dei tre kronen slapp vi å betale. Tre kroner var jo fryktelig billig, men Andreas kom att med en 17-18-19 kroner uka, åsså var det 4 støkker ta øss som skulle ha. Men når-n gikk på butikken med en tikroning, så fekk en jo mat for hele uka.

I tillegg til sjølve leiligheta $\mathrm{i}$ bolin så var det bod i kjelleren og på loftet, vedskåle og do. Bryggerhus, steinrulle, badstu og tørkeloft var fælles. Alle 20 leilighetene var sammen om 
20 bryggerhuset, så det gikk over 14 dager mellom hver gang en hadde vaskedag:

Det var slik at når en vaske klær, da ropte og vinke dom: Nå er kaffen ferdig! Je gikk åt bryggerhuset klokka 9 om kvelden, for je skulle vara innatt til mannen min gikk på jobben klokka 6. Og da kom hu som bodde ved sida ta meg, hu Petra Moen, borti bryggerhuset åt meg klokka 4 om mårrån hu, og sier at nå er kaffen ferdig, Petra. Og når je kom opp så hadde hu kokt ertersuppe. Så spiste vi fysst ertersuppe, og så drakk vi kaffe.

Når Petra forteller om dette 60 år etterpå, er det gode naboskapet som var mellom alle $\mathrm{i}$ arbeiderboligene det hun husker best:

Alle sammen var akkurat soom en hel familie. - Åsså var det det som var så kjekt at det var ingen som klaga. Ingen bar seg ille for at dom hadde for lite rom. Ingen bar seg ille for at dom hadde for lite penger. Ingen bar seg ille for at dom itte hadde det fint nok.

Petra forteller at noe hun har tenkt på seinere er:

åssen ælle kunne ha det så gullane reint som dom hadde det der, da dom hadde så lite rom. Det var så fint, helt blankpusse alle stan. Vi pusse komfyrn hver lørdag så den var speilblank. Vi snakka om det, husser je, at vi itte visste å vi sku bruke julekvelden, for sjøl om vi brukte risengrynsgraut, så var vi redd for at det skvatt på omn så-n itte var blank te om juledagen.

Det som var negativt ved bolin var at "om vintern så frøys det is innover kjøkkengolvet, og da vi hadde små onger, måtte vi legge ulltepper på golvet”.

Nå er det miljøet disse arbeiderboligene dannet på Raufoss forlengst borte. På Toten Museum håper vi derimot å kunne føre noe av dette videre. Til dette trenger vi hjelp av alle som kan fortelle om dette miljøet. Vi vil selvsagt også svært gjerne ha gjenstander til møbleringen av leilighetene.
Petra Jensens 60-års minner fra boligen belyser et miljø og et område av vår kulturhistorie som de fleste idag ikke har kunnskap om, men som mange har sine røtter i.

\section{Note}

- Artikkelen er tidligere gjengitt i Oppland Arbeiderblad 1977. Här återgiven efter TOTN. Årbok 1988, s. 127-130. (Gjøvik 1988)

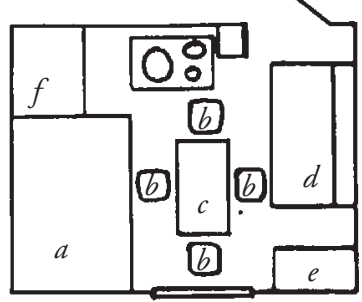

Fig. 1. Grunnriss over ettromsleiligheta i Roset: $a$ : dobbeltseng, b: pinnestoler, c: kjøkkenbord, d: buffet, $f:$ bord til matlaging/vaskestell, e: kommode.

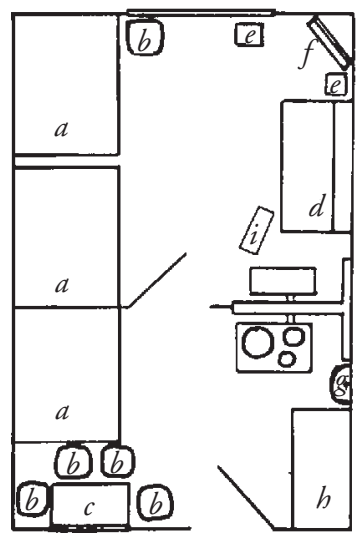

Fig.2. Grunnriss over Petras leilighet i boligen. Her bodde det 6 personer. a: dobbeltsenger, b: pinnestoler, $c$ : kjokkenbord, d: buffet, e: blomstersoyler, f: speil, g: vannkran og utslagsvask, h: kjøkkenbenk, i: kaminkrakk. På veggene var det familiebilder, og et par malerier. Gardinene var hengt opp på hjemmelagede gardinstenger, med kjøpte spyd $i$ endene. Kjøkkenet var blät med brun linoleum på golvet. Stua hadde lysegrønne vegger og morkegront golv. 


\title{
"MuSEUMSMÆND OG DERES SKIDNE TØI”
}

\author{
John Aage Gjestrum
}

Museumsforbundet ble til for å forsone «central- og lokalmuseer» Når vi nå 75 år etterpå skal forsøke å forstå hva det var som skedde, kan det vare riktig å se dannelsen av museumsforbundet som et kompromiss mellom til da sterkt motstridende og tydelig formulerte oppfatninger av hva et museum i Norge skulle vare. Samtidig var en museumsprofesjon under etablering og ville sikre sitt grep på museene.

I Norden har vi to linjer i museenes historie. Ei linje går tilbake til de kongelige samlinger av kunst og fornminner, etterhvert innordnet i museer på 1800-tallet, fulgt av etableringen av arkeologi og kunsthistorie som særskilte fagdisipliner. Museet som institusjonstype slik vi kjenner det, ble da til. Målsettingen mot midten av 1800-tallet var et bredt anlagt nasjonalmuseum i hvert land. I Danmark kunne Christian Jürgensen Thomsen (1788-1865) slå opp dørene til sitt nasjonalmuseum i 1855. Og dette har overlevd alle senere begivenheter i Danmark. I Sverige åpnet det tilsvarende Nationalmuseum i 1866. Det fikk imidlertid senere en mektig konkurrent i Nordiska Museet, og falt etterhvert gjennom 1900-tallet fra hverandre i flere institusjoner. I Norge ble det også på 1860-tallet planlagt et stort anlagt nasjonalmuseum, som imidlertid ikke ble realisert verken da eller senere. Museenes oppgave var å underbygge bevisstheten om nasjonens ære og storhet.
Mot slutten av 1800-tallet fikk vi så en ny museumsretning der en betonte det nasjonale også i folkelig kultur og formidling, og der friluftsmuseet ble utviklet som et av de fremste kjennetegn. Artur Hazelius (1833-1901) var her en fanebaerer, - i Danmark Bernhard Olsen (1836-1922) og i Norge Anders Sandvig (1862-1950).

Motsetninger som i samtida var svært kraftige, mellom det vi kan kalle et mer folkelig rettet museumsarbeid i kontrast til det akademiske, er i ettertid tonet ned. Ja, de er i mange tilfelle helt gått inn i glemmeboken. Dette har selvsagt skjedd fordi folkene i det akademisk-vitenskapelige miljø etterhvert tok over og "profesjonaliserte" de folkelig rettede museene, og da glemte de enkelt nok det" som ikke passet". I denne artikkelen om etableringen av det norske museumsforbundet NKKM, Norske Kunst- og Kulturhistoriske Museer (NML - Norske Museers Landsforbund til 1963), vil vi se at konfliktene mellom 
22 de to svært forskjellige museumssynene i vesentlig grad danner bakgrunn for hvordan museumsforbundet ble til.

\section{"Mere Skade enn Gavn"}

Mens han levde stod Artur Hazelius så sterkt i det offentlige bildet i Sverige, at ingen der i det tradisjonelle museumsvesen virkelig turde å angripe han. Det skjedde imidlertid i taushet umiddelbart etter hans $\mathrm{d} ø \mathrm{~d}$ ved at hans ideer ikke ble virkeliggjort. Historien om dette er synliggjort i Ernst-Folke Lindbergs arbeid om Nordiska museets "installationsfråga". Arkeologene med sine typologiske serier overtok, godt fulgt av kunsthistorikerne, og Hazelius' folkelige formidling med dioramaer gikk i glemmeboken (Lindberg 1957, Ågotnes 1993).

I Danmark var respekten for Hazelius imidlertid ikke så stor som i Sverige. Og da Bernhard Olsen begynte på sitt friluftsmuseum i 1897, gikk den ledende danske arkeolog og museumsmann Sophus Müller til et skarpt angrep der han slår fast "den systematiske Opstilling af originale Gjenstande som den eneste Museumsordning af videnskabelig Værd", mens han betraktet "maleriske og illuderende Interiører og Friluftsmuseer som en art Kunstanstalter, der gjorde mere Skade end Gavn m.H.t. arkæologisk-historisk Forstaaelse.

De måtte finne et annet navn på virksomheten enn museum, de kunne ikke bruke museets, hevdet Müller (Rasmussen 1979:179).

Arkeologiens vitenskapsmenn var altså ved århundreskiftet i stor grad uforstående til folkelige museer da de kom, altså museer som ikke bare først og fremst kommuniserte vitenskapens kunnskaper. Arkeologene hadde også et sterkt utbygd felles nordisk nettverk, og framstod som museenes fremste "profesjonelle" vitenskapsmenn.

I 1901 søkte De Sandvigske Samlinger på Lillehammer om statstilskudd for første gang. Arkeologiprofessoren Gabriel Gustafson (1853-1915) ved Universitetets Oldsaksamling i Oslo gikk i en avisartikkel sterkt imot dette: "Hva der først og fremst gjelder er Norges kulturhistorie, ikke Setesdalens eller Gudbrandsdalens". Han argumenterte sterkt for at alle må stötte opp under det nye Norsk Folkemuseum, så det" "snart og i stort kan vise oss det norske folk i bilder fra bygd og by. $\mathrm{Og}$ skulle det ikke lykkes å få alt samlet $\mathrm{i}$ ett museum, saa lad det blive i Östlandet og Vestlandet og Nordlandet hvert paa sit sted. Tre eller fire Landsmuséer kan endu lade sig høre, men hundrede - umuligt." (Gustafson 1901).

Professor Gustafson kom til å ta feil, - ja grundig feil i dette. Allerede før slutten av 1930-tallet var det i Norge kommet til over 100 museer av folkemuseumstypen. Og idag er det altså ikke bare blitt hundre, men kanskje 1.000 store og små samlinger og museer i Norge (Gjestrum 1993: 32).

De Sandvigske Samlinger fikk sitt statstilskudd i 1904, samtidig med museets åpning på Maihaugen. Det var riktignok bare beskjedne 2.000 kroner årlig, men prinsippet ble etablert, - og på tvers av mange sentrale fagfolks oppfatning.

\section{Stadig Flere LOKalmuseer}

Snart førte motsetningsforholdene mellom landets museumstyper til åpen strid, og det var forholdet til statstilskuddene som ble den utløsende faktor. Omkring 1911-12 ble det gitt statstilskudd til museene i de større byene Oslo, Bergen, Trondheim, Tromsø og Sta- 
vanger, - der de hadde museumsvirksomhet knyttet til anerkjent vitenskapelig virksomhet. Videre ble det gitt tilskudd, men bare omlag 1/10 av nivået til museene i de store byene, til eldre altomfattende museer i Arendal, Skien, Tønsberg og Kristiansund.

Ei gruppe folkemuseer fikk også statstilskudd: Norsk Folkemuseum, De Sandvigske Samlinger, Kristiansand folkemuseum, Hallingdal Folkemuseum, Oplandenes folkemuseum (Hamar), Sogns folkemuseum (Heibergske) og Dalenes folkemuseum. Norsk Folkemuseum fikk kr. 19.000, De Sandvigske Samlinger kr. 4.000, mens de andre fikk kr. 600, med unntak av Dalenes folkemuseum som bare fikk kr. 200. Dette museet var imidlertid nystartet (1910).

Det lå imidlertid utviklingstrekk i tida som pekte klart mot en sterk bevegelse i retning av utbygging av flere lokalmuseer. Glomdalsmuseet var åpnet 1911, - og i tiåret 1910-20 kunne en i ettertid notere en vekst på 22 museer, de fleste lokalmuseer med regional karakter som Hadeland Folkemuseum (1913), Valdres Folkemuseum (1901), Sunnfjord Folkemuseum (1910), Hardanger Folkemuseum (1911), Nordfjord Folkemuseum (1908), Larvik Museum (1916), Voss Folkemuseum (1917), Sunnhordaland Folkemuseum (1913), Folkemuseet for Trondheim og Trøndelag (1913), Rana Museum (1910), Vefsn Museum (1909).

Av bygdemuseer (og bygdetun/bymuseer) finner vi ellers før 1920: Gamle Hvam, Trysil, Bagn, Hol, Fyresdal, Kviteseid, Grimstad, Mandal, Søgne, Hjelmeland, Kvam, Osterøy, Ålesund, Volda, Frosta, Leirvika. Oplysningene her bygger på registreringen gjort av "Museumskomiteen 1967" (1970).

Det var derfor ikke uten grunn Staten gjennom Kirkedepartementet i 1911 var urolig for hva som ville bli utfallet av den sterke veksten av museer av folkemuseumstypen, samtidig som de merket problemene konkurranse og kiving museene imellom skapte.

\section{Museumsdirektør Aall SOM "INSPEKTØR"}

En avgjørende begivenhet var at direktør Hans Aall (1869-1946) på Norsk Folkemuseum sommeren 1911 foretok en inspeksjon, eller slik vi kan lese i statsbudsjettet "at folkemuseets direktør efter anmodning fra departementet velvillig paatok sig paa sine reiser $i$ sommer at gjøre sig nærmere bekjendt med museumsforholdene paa de kanter av landet hvor han reiste". Dette skjedde samtidig med at departementet også foreslo opprettet en riksantikvarstilling, der departementet også hadde "tænkt sig at der til denne stilling ogsaa kunde henlægges en pligt til at føre tilsyn m.v. med vore folkemuseer". (St.prp. nr. 1, 1911:19).

I sin rapport bruker Aall første side på museumssituasjonen i Trondheim, hvor han argumenterer mot et "Trøndelag Folkemuseum", - "et nyt tredie museum i denne by, hvor der paa forhaand er mere end trange vilkaar for to". Større betydning fikk imidlertid hans omtale av De Sandvigske Samlinger på Lillehammer. Han traff ikke Anders Sandvig, men fikk inntrykk av at "museet arbeidet økonomisk set overordentlig tungt". Og videre, skriver Aall i sin rapport, "At det indre arbeide, som katalogisering o.l. ligger nede, er derfor undskyldelig, saalenge der i et museum med saa store dimensjoner ikke kan skaffes midler til at lønne dette arbeide med (Aall 1911: 73).

På dette tidspunktet fikk Norsk Folkemuseum omlag tre ganger så stort statstilskudd alene som alle de andre folkemuseene tilsammen. For Anders Sandvig som på flere måter 
24 så sitt Maihaugen-museum som likeverdig med Norsk Folkemuseum, er det ingen tvil om at han her ble mektig forbannet på Aall. Både fordi Aall uttalte seg uten overhodet å ha snakket med Sandvig, og ikke minst fordi han gjennom sin formulering om at "katalogisering o.l. ligger nede" her stemplet Sandvigs museumsvirksomhet som useriøs. Sandvig skrev til departementet at han er forundret over at "direktøren" har uttalt seg slik til departementet, "da han dog ikke er ubekjendt med mit arbeide: De Sandvigske Samlinger $i$ tekst og billeder, Et bidrag til Gudbrandsdalens kulturhistorie med 616 billeder, udkommet allerede for 5 aar siden. Af denne bog fremgaar det tydelig, at den færdige del af Maihaugen, anlæg, huse, indbo, redskaber, stort som smaat, af enhver art altid har været omhyggelig nednoteret, beskrevet og bestemt."

\section{LOKALMUSEENE MOBILISERER}

Det var ikke vanskelig å se for seg en framtidig riksantikvar knyttet nært til landets sentrale museumsmiljø, her ville kunne fortsette i den stil Aall la opp til. Anders Sandvig tar kontakt med vennen og museumskollegaen, godseier Gert Falch Heiberg (1871-1944) i Sogn. Sammen bestemmer disse seg for å organisere et møte for lokalmuseene i 1912. De vil kreve opprettelse av en uavhengig, sakkyndig inspektørstilling og likestilling med de øvrige museer. Ellers, som Heiberg skriver til Sandvig, "... glider det mot at vi blir underbruk, som faar vore instrukser fra riksantikvaren, der blir et redskap i folkemuseets og bymuseernes hænder."

Lokalmuseenes "gerilja-møte" ble holdt i Kristiania den 3. mars 1912. Det ble formulert en uttalelse på 5 sider der departementet og ikke minst Hans Aall ved Norsk Folke- museum og Haakon Shetelig (1877-1955) ved Bergens Museum ble imøtegått. Uttalelsen ble etter møtet gitt store oppslag $\mathrm{i}$ avisene, og den ble trykket og delt ut til samtlige stortingsrepresentanter. De kunne bl.a. lese:

Men naar det gjentagne fremholdes, at de større museer er det eneste sted, hvor arbeidet kan drives videnskabelig, da forekommer det os, at denne opfatning er meget ensidig. De mindre museers (bygningsmuseernes) opgave er ikke væsentlig at faa istand en skjematisk samling. Hvad de vil, er fortrinsvis at søke gjenopført de gamle fædres boliger og anskueliggjort deres liv i arbeide og fest, fra husmanden til odelsbonden og embedsmanden, saa fyldig og historisk riktig og saavidt detaljeret som det er mulig. - Skal en forsker indgaaende studere sit lands gamle kultur, maa han selvfølgelig søke derhen, hvor det rikeste materiale findes. Vel har flere av de lokale museer endnu ikke noget fagbibliotek for studier, men det vil nok komme ialfald for manges vedkommende. Arbeidet er endnu i sin begyndelse.

Om inspeksjonen av de statsstøttede museer uttalte lokalmuseene:

Hvis imidlertid den inspektion, som hr. direktøren for Norsk Folkemuseum isommer foretok ved enkelte museer på anmodning av Departementet, skal være rettesnor for den fremtidige inspektion, da finder vi, at denne litet kommer til at stemme med den oprindelige hensigt. Skal en inspektion av museene samtidig bli en gjensidig veiledning til nytte for dem og Departementet, bør den vel ogsaa ske med museernes vidende. $\mathrm{Og}$ skal den bli retfærdig og formaalstjenlig, bør den utføres av en dertil skikket mand, som ikke selv er direkte interessert i de statsunderstøttede museer. Hensigten er vel, at inspektionen skulde være et sympativirkende bindeled mellem de forskellige museer og administrationen. Vedkommende inspektørs eller konsulents opgave bør ikke alene være den at inspisere. Han bør være en fast statskonsulent, til hvem de enkelte museer 
naarsomhelst og uten utgifter kan henvende sig for at faa veiledning og raad baade i spørsmaal av bygningsteknisk og bygnings-arkeologisk art samt i spørsmålet om nyanlæg, priser, ordning, museumstekniske raad og lignende.

Lokalmuseene ba også på møtet i 1912 om at de må få rett til å oppbevare oldsaker, da det "har vist seg, at mange forhistoriske gjenstande omkring i landdistrikterne forekommer eller ikke indsendes til de store museer, medens lokalmuseerne her kan gripe reddende ind og derved samtidig vække den historiske interesse og forstaaelse i sine distrikter."

Direktør Aall på Norsk Folkemuseum hadde skrevet til Sandvig og bedt han om å trekke tilbake kritikken. Dette var selvsagt nytteløst. Istedet framstod nå konflikten mellom lokalmuseene og "centralmuseerne" tydelig i offentligheten med store presseoppslag.

"Vi tror, der nu overalt, saavel ute i Folket som hos det Offentlige, er vaaknet en utbredt Forstaaelse og Erkjendelse av Lokalmuseernes betydningsfulde Opgave, omend denne Erkjendelse paa enkelte Hold ikke synes helt avklaret endnu", sier godseier G. F. Heiberg i lokalavisa Sogningen i august 1912.

\section{HistoriKERMøTET I9I2.}

\section{A.W. BrøgGer ENTRER SCENEN}

Så ble da også "kampen mellem museer" en av de heiteste sakene i 1912 under det forste norske historikermøtet. Det var den 28-årige unge konservatoren fra Stavanger Museum, Anton Wilhelm Brogger (1884-1951), som fikk i oppdrag å innlede diskusjonen om "forholdet mellem centralmuseer og lokalmuseer". I Aftenpostens referat fra møtet kan vi lese at spørsmålet først gjaldt "lokalmuseernes uvilje mot centralmuseernes 'lange fang- arme', dernest frygten for, at lokalmuseerne skulde blive rene raritetskabinetter". Brøgger fant det forståelig at "lokalmuseernes mænd nærer animositet mot centralmuseernes trang til at krafse til sig gjenstande”.

Brøgger fortsetter videre i talen å påpeke at lokalmuseene har en viktig oppgave i å vekke interesse for innsamling. En var kommet sent igang, så nå gjaldt det først og fremst å samle. Om noen år vil det så bli et sterkt krav på vitenskapelig bearbeidelse av det innsamlede materiale, "og da kan vi ikke undvære centralmuseerne, da vil det simpelthen være at spare paa kræfterne at lade disse løse de videnskabelige opgaver. Vi har tre naturlige sæder for centralmuseer, nemlig Kristiania, Bergen og Trondhjem, hvorhos Tromsø museum indtager en særstilling."

\section{EN "ORGANISASJON"?}

Likevel, sier Brøgger, hvis en innrømmer at lokalmuseene har en viktig oppgave ved siden av sentralmuseene, bør det være en museumsinspektør, en statens mann som har inspeksjon over alle museer i landet. Han legger også fram forslag om en organisasjon, et museumsråd eller representantskap som kan ivareta samarbeidet mellom museene, som "kunde fastsætte insamlingsomraadet for hvert enkelt museum, fatte beslutning om nye museer, kontrolere forholdet mellem centralmuseerne og lokalmuseerne, sørge for foredrag om museumsvirksomhed osv." Han foreslo så at det skulle nedsettes en komité for å utrede spørsmålet om en organisasjon.

Diskusjonen som fulgte etter Brøggers innledning ble svært livlig, ja så livlig at en av talerne, professor Gran, uttrykte virkelig engstelse for at også neste historikermøte "skulde udsættes for en lignende". 
Ikke overraskende var godseier G. F. Heiberg en av de som sterkt framholdt betydningen av å ha lokalmuseer til å samle i hvert sitt distrikt. Norsk Folkemuseum kan ikke og "maa ikke forsøge paa at blive hovedsædet for det hele land", sa Heiberg, og fortsatte: "Om man lægger nogle bygninger ude paa Bygdøsletten, saa giver jo ikke det noget billede af en bygd". Heiberg uttrykte seg "meget mod museumsraad etc. Møtet var heller ikke kompetent til å nedsette en slik komité som Brøgger hadde foreslått, hevdet Heiberg.

Det ble imidlertid en konklusjon i møtet som vel måtte være et kompromiss, nemlig at A. W. Brøgger og Anders Sandvig skulle arbeide videre med spørsmålene, og mot utarbeiding av et forslag til stiftelse av en forening. Som vi vet gikk det nesten 6 år för dette forslaget ble lagt fram, og Norske Museers Landsforbund kunne bli en realitet i 1918 .

\section{BRøgGER OG SANDVIG NÆRMER SEG HVERANDRE}

I mellomtida hadde Anders Sandvig, fortsatt ved siden av sin tannlegepraksis, fullt opp å gjøre på Maihaugen med ferdigstillelsen av Björnstadanlegget, som var det største prosjekt noe folkemuseum til da hadde kastet seg inn i. Dessuten var det store oppgaver i forbindelse med jubileumsfeiringen knyttet til grunnlovsjubileet i 1914 .

A.W. Brøgger flyttet fra Stavanger til Kristiania i 1913, der han ble underbestyrer ved Universitetets Oldsaksamling. I 1915 døde så professor G. Gustafson, og Brøgger ble professor og bestyrer for samlingene. Mens flere av hans arkeolog-kollegaer både i Norge og ellers i Norden hadde uttrykt stor skepsis til folkemuseumstanken og ikke minst til lokalmuseer, forsøkte Brøgger å sette nye perspek- tiver på det folkelige museumsarbeidet. I en artikkel i Aftenposten i 1914 om Fortidsvarn og folkemuseer, som han antakelig skrev etter han i juli besøkte Sandvig, pekte han på 1890tallet som den viktige brytningstid. "Alfor længe" hadde det gamle regimet i Foreningen til norske fortidsminnesmerkers bevaring sittet inntil "systemskiftet i 1899", og de ekspedisjoner arkitekt Hermann M. Schirmer (1845-1913) foretok inn i norske daler fra 1895 brakte fram en ny bevissthet om norsk folkekultur. Folkemuseene kommer nå, skriver Brøgger, inn som "klare udslag af vext $\mathrm{i}$ kulturbevidstheden. Nu og altid vil deres hovedopgave være den kulturelle og æsthetiske”. Han sier han vil vike unna for å bli for detaljert, og "Navne skal ikke her nævnes. Bare et, som staar for sig selv, Anders Sandvig".

Brøgger peker også på at folkemuseene "før eller senere maa tage hensyn til den store videnskabelige opgave, som venter. Endnu har ingen forsker dukket tilbunds i det store stof, som heder norsk folkekunst". Han viser til at det nå er blitt folkemuseer i de forskjelligste bygder, - de aller fleste "udsprunget af det umiddelbare instinkt, som alligevel skylder det nye syn og den nye tid sin gnist”. Nå er museene " $i$ det ydre bleven en faktor, de er bleven 'en post paa kulturbudgettet', der er m.a.o. reist en række spørgsmål om deres vext og fremtid, som de før eller senere helst saamlet maa løse", skriver Brøgger avslutningsvis i sin artikkel.

Vi finner imidlertid ingenting som tyder på at Brøgger og Sandvig på denne tida foretok seg noe sammen med tanke på organiseringen av museene. 
RiksantikVAR, MUSEUMSinSPEKTøR OG "KLIKKENS MEDLEMMER"

Anders Sandvig var etterhvert også mer usikker på hvordan en inspektørstilling for museene ville bli. Da Riksantikvarstillingen første gang ble besatt, var det med H. M. Schirmer, som Sandvig hadde samarbeidet lenge med. Men han døde få måneder etter utnevnelsen. I 1913 var stillingen utlyst på nytt. Kristofer Visted (1873-1949) ved Fylkesmuseet for Telemark og Grenland i Skien skriver til Sandvig om "inspektørposten" som de har arbeidet for. Han sier han har gitt opp troen på at det vil lykkes, for slik som "de departementale forhold fortiden er" måtte de være forberedt på at inspektørstillingen vil bli "bortsnappet av en af klikkens medlemmer; det vilde jo være at lage ris til sin egen bak", skriver Visted. Han forteller også til Sandvig at han har fătt rede på at det vil bli nedsatt en sakkyndig komité for vurderingen av søkerne av riksantikvarstillingen "som var saaledes sammensat, at H.F.s utnævnelse paa forhaand var sikret, og dermed er det givet, at der er sat en bom for vore planer. Saaledes opfatter altsaa jeg for nærværende situationen", skriver Kristofer Visted til Sandvig.

Det Visted da ikke kunne vite var at det faktisk var Anders Sandvig som ble oppnevnt til å være museenes representant i den sakkyndige komitéen. Mens kunsthistorikeren Harry Fett (1875-1962) ved forrige tilsetting ble vraket til fordel for Schirmer, var han nå etter komiteens mening den beste av de tre som søkte. Bare historieprofessoren Halvdan Koht gikk imot Fett. Kort tid etter at Fett ved årsskiftet 1913-14 var tilsatt som Riksantikvar, ble Sandvig sammen med andre invitert hjem til en selskapelig sammenkomst hos Fett. Noen dager etter skriver Sandvig til
Fett og ber om støtte til opprettholdelse og muligens styrking av statens tilskudd til Maihaugen. I sitt svar gir Fett det råd til Sandvig å "søke at frigjøre dit museum lidt fra de andre museerne og især hævde din særstilling ligeoverfor et par andre museer, som jo har varme talsmænd i regjering og paa tinget". Et par år senere arbeider Fett for å støtte Sandvig i å få lønn for sitt arbeid som direktør på Maihaugen. Men noe hjertelig forhold virker det likevel ikke å være mellom disse to. Noen studie av hva slags råd Fett som riksantikvar har gitt myndighetene i museumsspørsmålene har ikke vært gjort.

Mens riksantikvaren i departementets begrunnelse for stillingen i 1911-12 forutsettes å være øverste myndighet også for museene, ser dette ikke ut til å ha blitt gjort gjeldende. Det kan nettopp skyldes den sterke striden som oppstod imellom lokalmuseene og sentralmuseene om spørsmålet.

Riksantikvaren tok i 1917 igjen opp spørsmålet om sentralinstitusjon for museumsarbeidet. Nå er det departementet som ikke vil knytte riksantikvaren til dette, - istedet etablerer de i 1918 Kulturminneradet som en kontrollerende og rådgivende myndighet, også "til fyremål å arbeide for einskap og samarbeid millom dei som granskar og samlar alt av gamalt kulturhistorisk verde". Det er i denne situasjonen museumsfolkene da i 1918 etablerer Norske Museers Landsforbund (Shetelig 1944: 322-323).

Kulturminnerådets medlemmer ble oppnevnt for 3-årsperioder. Lederen for rådet ble også nettopp historieprofessor $\mathrm{H}$. Koht, som altså også hadde gått mot at Fett skulle bli riksantikvar. En kan ane at det ligger mer under her? Etter siste oppnevning i 1923 ser Kulturminnerådet imidlertid ut til å " avgå en stille død". I Riksarkivet, der rådets arkiv nå 
28 ligger, finner vi lista over hvem som skulle sitte til 1926, men i møteprotokollen er sidene blanke. Da hadde museene istedet lykkes med å skape "einskap og samarbeid" gjennom NML, og museumsforbundet ble en mye viktigere og mer hensiktsmessig samarbeidspart for departementet enn Kulturminnerådet. NML overtok derfor raskt også alle oppgavene, og fylte statens behov for ha grunnlag for å gjøre faglig funderte og legitime beslutninger vedrørende museene. Og aller viktigst: striden om hva som skulle gis prioritet ble avgjort i museumsforbundet, og departementet slapp unna skuddlinjen.

\section{De "FAgutdannede MUSEUMSMæND"}

Den 12. april 1918 møttes professor A. W. Brøgger og tannlege Anders Sandvig på Eidsvoll for å forberede et møte av "museumsfolk til dannelsen av en norsk museumsorganisasjon”. De viste til mandatet gitt på det norske historikermøtet i 1912. I tillegg supplerte de seg med konservator Anders Bugge (18891955). De utarbeidet et dokument i 30 punkter som ble distribuert til aktuelle museer sammen med et følgebrev som inviterte til konstituerende møte i Kristiania 6-7. juni 1918. Dokumentet inneholdt også ei liste over hvilke museer en mente var aktuelle medlemmer av en norsk museumsorganisasjon, i alt 49 museer. Disse skulle være "grundlag for medlemskapet", og "Medlem blir derved enhver fagutdannet museumsmand knyttet til de samme museer. De museer derimot som ikke har fagutdannede folk opnævner en repræsentant som enten må være den som daglig leder vedkommende museums arbeide eller en blandt de fagutdannede opnævnt stedfortræder".

En av de som hadde deltatt på historiker- møtet i 1912 var konservator Albert J. Lange (1856-1922) ved Eidsvollsminnet. Den 5. mai 1918 skriver han til Anders Sandvig og forteller at han dagen før hadde mottatt innbydelsen til å delta i konstitueringen av "Norske Museers Landsforbund", men "Saa gjerne jeg end skulde ville tiltræde dette forbund", tror han nok at han bør holde seg vekk. Han hadde nemlig fått "anmodning om at delta i det første norske historikermøte i Christiania", som han skriver i brevet til Sandvig, og fortsetter: "og var saa dum at melde mig, uaktet jeg burde vite, at i vort elskede frdreland anses kun den som historiker, der har absolvert examen artium. Jeg fik da ogsaa straks straf for min dristighed at følge anmodningen om at delta i møtet. Den unge hr. Skavlan, dengang medarbejder i 'Verdens Gang' eller 'Tidens Tegn', nu redaktør av 'Dagbladet', skrev en vistnok uhyre vittig artikel i sit blad om deltagerne i møtet og nævnte derunder 'vaktmestre med historisk lesning' selvfølgelig myntet på mig."

Da Lange i 1895 ble konservator og sekretær for "Selskabet til Eidsvolds-bygningens Udstyr", skjedde nemlig det at vaktmesterstillingen ble ledig året etter. Funksjonene ble så slått sammen, og Lange fikk utvidet sitt konservatorengasjement. Hans tidligere bakgrunn var imidlertid bokhandler. Det som i 1912 gjorde han bitter, var imidlertid ikke alene dette at han ble latterliggjort i pressen, men "at bestyrelsen for møtet ikke tok en av sine deltagere i forsvar. Det passer sig nemlig ikke for spurver at delta i tranernes dans!" skriver Lange i 1918.

Nå vil ikke Lange oppleve en slik behandling "for ikke at si mishandling" setter Lange i parentes, som det han opplevde i 1912. Frykten for at dette nemlig kan skje igjen finner han i dokumentet han har mottatt: 
Av indbydelsen ser jeg, at forutsætningen for at bli medlem er, at man er 'fagutdannet'. Jeg maa bekjende, at jeg ikke riktig forstaar betydningen av dette ord i denne forbindelse; thi saavidt mig bekjendt har vi ingen skole eller institut for musæumsfolk; vi har vistnok et kunstakademi, som jeg dog har troet var mest beregnet paa bildende kunstnere. Og jeg tror, at kun faa av vore musæumsfolk har frekventert dette. Der har vistnok ved flere av vore musæer været avholdt foredrag, saaledes ved Chria og Bergens kunstindustrimusæer, ved folkemusæet paa Bygdø o.a., men dette er veel ikke sket for i første række at 'fagutdanne' museumsfolk.

Det er interessant å se her at Albert J. Lange faktisk som sin første reaksjon på møtet med et dokument fra det som skal bli museumsforbundet, peker på et hovedspørsmål som siden aldri er lost: nemlig at museene har 'fagutdannede folk, de er bare fagutdannet $i$ noe annet enn hva museet som institusjon og medium er!

Mot slutten av brevet kommer så Lange til den egentlige årsak til at han skriver til Sandvig. Erfaringen fra 1912 synes han tilsier at han ikke nå gjentar eksperimentet fra den gang, men holder seg "beskedent tilbake... med mindre Du da skulde kunne garantere mig, at jeg vil bli antat som medlem, om jeg skulde besvare den mig oversendte indbydelse med ja. Og en saadan garanti maa i tilfælde være ubetinget, thi en halvvejs forsikring vil skræmme mig væk." (Langes uthevelser)

Lange håpet Sandvig kunne gi et raskt svar, ettersom svarfristen den 20. mai var like om hjørnet. Sandvig ga da også temmelig sikkert et svar med en slik forsikring som Lange ba $\mathrm{om}$, for når vi ser på deltakeroversikten i protokollen fra stiftelsesmøtet 6. juni 1918, finner vi "konservator Lange, Eidsvoldsmindet" som en av de 36 deltakerne som etablerte museumsforbundet.
"MAAL FOR FORBUNDETS VIRKSOMHET"

Målsettingene med etableringen av museumsforbundet som Brøgger, Sandvig og Bugge formulerte forut for det konstituerende møtet i juni 1918, var gruppert i fire hovedgrupper:

Først ble ønsket om å være rådgivende for departementet ved bevilgninger til museumsformål presentert, «bl.a. ved oprettelse av nye museer og bevilgninger til disse». En vil også oppnevne de fire museumsrepresentantene i det som en tror departementet vil opprette under betegnelsen "Den Antikvariske Kommisjon", men som vel i 1918 ble Kulturminnerådet.

Som mål for forbundets virksomhet ble det satt opp krav om regulering av "de fagutdannede museumsmands lonninger".

Det neste punkt tar vi inn i sin helhet: "Som næste og meget nærliggende maal bør opstilles kravet til norske museumsmands faglige utdannelse. Man gaar ut fra at dette maa løses i forbindelse med spørsmålet om obligatorisk undervisning i norsk kunsthistorie og arkeologi ved Universitetet saaledes at der for dem som vil gaa museumsveien maa bli adgang til at ta examen i faget ved Universitetet". Dette ble også realisert allerede etter et par år, med opprettelse av et professorat i norsk kunsthistorie. Men om det løste kravene til Museumsutdannelse i Norge, er vel i ettertid kanskje mer åpent?

I invitasjonen til å stifte museumsforbundet finner vi som fjerde og siste mål for forbundetsvirksomhet at de burde opstille løsningen av spørsmålet om sakkyndig veiledning og tilsyn med museerne. Komiteen er enig om at foreslaa som den bedste ordning, at Riksantikvaren overtar et saadant hverv. 
30 Den anden løsning med opprettelsen av en egen inspektørstilling vil man anse for mindre heldig. Som et tredje alternativ har komiteen drøftet muligheten av at bestyrerne for de større distriktsmuseer skulde overta tilsyn og veiledning av de mindre, men da man finder at en saadan ordning byr paa praktiske vanskeligheter, som for tiden ikke kan løses, vil man ikke kunne anbefale dette alternativ. Derimot bør det saavidt mulig sørges for at der for de mindre museers vedkommende, hvor der ikke findes fagmæssig utdannede folk, skaffes midlertidig hjælp til katalogisering, ordning, flytning og opførelse av gamle bygninger o.s.v. I denne sammenhæng mente man likeledes at burde foreslaa at forbundet skulde søke sat igang en registrering av norske gjenstande i utenlandske museer i forbindelse med den av Riksantikvaren foreslaatte inventarisering.

Nå ble det ikke Riksantikvaren, men Kulturminnerådet, som fikk denne overordnede oppgaven. Antakelig må både etableringen av museumsforbundet nettopp på dette tidspunktet, og ihvertfall uttalelsen i invitasjonsdokumentet om at de ville ha Riksantikvaren som faglig overordnet museene, sees som et innlegg imot departementets opplegg med Kulturminnerådet. Her ser vi også det at Sandvig har skiftet oppfatning ved å gi oppgaven til Riksantikvaren og ikke til en inspektørstilling. Det var dette siste som var et av hovedkrava han fikk de andre lokalmuseene med på i 1912. Forklaringen må da ligge nettopp i forholdet til det kommende Kulturminnerådet. Dessuten var nok Sandvig en god pragmatiker og strateg, - han gir noe og får noe. Og det han fikk, som nettopp på denne tida var et svært aktuelt spørsmål, var å kunne få godtgjøring for sitt museumsarbeid, slik at han i større grad kunne arbeide full tid med museet, og i mindre grad som praktiserende tannlege. Slik gikk det da også. Han ble i 1918 konservator, i 1921 direktør for samlingene (Buggeland/Ågotnes 1987:100-102).

\section{ET NYTT BALANSEPUNKT}

Det er ingen tvil om at dannelsen av museumsforbundet i vesentlig grad må sees nettopp som en løsning på de harde motsetningene mellom lokalmuseer og sentralmuseer gjennom de foregående nesten 20 år. Den som var arkitekten i å finne mellomveier og løsninger var den unge arkeologen A.W. Brøgger. Selv om han ikke lyktes i 1912, så innledet han et forhold til lokalmuseene, - etterhvert først og fremst gjennom deres mest markerte frontfigur Anders Sandvig.

Han trekker også Sandvig inn når Skandinavisk Museumsforbund etableres i $1915 . \mathrm{Og}$ ved planleggingen i 1916 av neste års møte i Norge i 1917, ber han Sandvig om å være vert for deler av møtet. Her ble det altså gradvis bygget opp et tillitsforhold, der andre fra sentralt faglig hold i stor grad hadde opptrådt langt mer konfronterende.

A.W. Brøgger kom så til å sitte som formann i Norske Museers Landsforbund fra 1918 til 1933, og med det opprinnelige styret fra 1918 nær uendret gjennom hele perioden. Gjennom alle disse 15 år hadde han med seg Anders Sandvig i styret. Men der var også den like temperamentsfulle godseier fra Sogn, C. F. Heiberg. Han satt i styret helt til 1940, mens Sandvig gikk ut i 1934. Også lokaliseringen av museumsforbundets landsmøter avspeilet denne holdningen hos Brøgger. I 1919 var det i Kristiania, i 1920 i Bergen, - men så følger Drammen, Lillehammer, Kristiania, Hadeland, Stavanger, Elverum, Bergen, Oslo, Skien og i 1930 i Trondheim. Vi må kunne si 
at Brøgger etablerte et helt nytt balansepunkt mellom ulike deler i det norske museumsmiljøet.

Det var på NML's landsmøte i Bergen i 1920 at Brøgger i sin årsmøtetale tok oppgjøret med historien bak dannelsen av museumsforbundet:

Da det for endel aar tilbake blev liv i rosenes leir gjennem det stadig stigende antal av nye smaa lokalmuseer i landet, reiste det sig snart en stor og ofte bitter strid om centralmuseer og lokalmuseer - hvor de store fra de smaas synspunkt syntes mægtige, griske, havesyke, haarde og uforstaaende, og hvor omvendt de smaa syntes de store at være overflødige, trangsynte, kjæmpende i Baglerbispens aand. Denne strid er og maa være forlængst skrinlagt som fuldkommen hensigtsløs og taapelig. Vi er nu allesammen paa det rene med nytten og betydningen av distriktsmuseer, og vi er igang med at etablere samarbeidet mellom museene overalt og til alle sider. - Decentralisationen av museumsvirksomheten har foresvævet enkelte som et program. Det er selvfølgelig i sig selv et helt ideløst program og har intet med museumsarbeidets indre at gjøre. - Det er overhodet kravet til arbeidets kvalitet son, maa og skal være det ledende. Ved at indrømme dette og ved at bruke det som rettesnor for vor avgjørelse av de saker vi maatte møte omkring dette spørsmål, finder vi overhodet en naturlig løsning paa alle de stridsspørsmål som engang plaget vor gjerning. - Der foregaar - uten at det synes paa overflaten - litt efter litt en omvurdering av vort arbeide ogsaa indenfra, hos os selv. Vi bygger de store museer og begynder at skjønne at de smaa kan løse opgaven sikrere, klarere, klokere. Vi vender tilbake til kvaliteten som det bestemmende, vi søker til kjernen av det at se og vite og kunne, og vi befrir os langsomt og sikkert fra fordomme, griskhet, samlergalskap, for at modellere ut tanken om et litet museum hvor sindet kan fyldes av noget av den oprindelighet, enkelthet og helhet som gav det bedste i det gamle liv. (Brøgger 1920: 251-252).
Et fullt så romantisk syn på lokalmuseene hadde ikke alle som holdt på med denne typen museum. Det kan derfor passe å avslutte artikkelen med hva Rikard Berge (18811969), som da ledet Fylkesmuseet for Telemark og Grenland, i 1919 formulerte i tidsskriftet Norsk Folkekultur som sitt syn, mens de ennå sloss for "decentralisasjon":

De er viktigare aa verja kulturminni paa heimstaden enn de er aa hope deim upp paa eit museum. De er viktigare for ei bygd aa sjaa sine gjæve kulturminne for augo kvar dag enn de er aa sjaa deim ein gong i livetidi paa eit museum langt undan. De er viktigare for vitskapen aa studere tingen i sitt miljø enn lausrivn fraa dette.

(Sitert fra Espeland 1974: 73). Mange vil kanskje finne at dette er et godt program også 75 år etterpå?

\section{ETTERSKRIFT}

Framstillingen i artikkelen følger først og fremst motsetningen mellom de ulike museumstypene som utgangspunkt for etableringen av museumsforbundet. Jeg skylder takk til førstekonservator Jakob Agotnes ved De Sandvigske Samlinger, som har pekt på aktuelt kildemateriale som nettopp viser denne sammenhengen.

En annen innfallsvinkel $i$ en mulig mer omfattende studie ville være å se mer utførlig på hvordan staten gjennom departement og storting i dette tidsrommet forholder seg, og hvordan deres inngrep med museumstilskudd, etableringen av rlksantikvarembetet og Kulturminnerådet virker inn.

Et tredje perspektiv ville være å utdype nærmere forholdet mellom profesjonalisering og organisasjon. Lignende museumsorganisasjo- 
32 ner var etblert $\mathrm{i}$ andre land, ikke minst for å sikre interessene til bestemte typer vitenskapelige tjenestemenn. At de ved etablering av museumsforbundet forsøker å monopolisere museumsarbeidet er tydelig nok. Og fra det som skjedde etterpå, vet vi også at de lyktes overmåte godt med det. At dette samtidig har betydd en innsnevring av museenes innhold og oppgaver har det derimot vært lite snakket om. Om den vellykkede profesjonaliseringen skriver imidlertid Aagot Noss i sin artikkel til NKKM's 60-årsjubileum (1978). For å bruke termen til den franske kultursosiologen Pierre Bourdieu om den kulturelle kapitalen: Det er ingen tvil om at museumsfolkene ved å investere $\mathrm{i}$ enhet og samling og å etablere sin egen organisasjon i 1918, skapte en allianse som både sikret deres kulturelle kapital, og antakelig også gjennom disse 75 år har forrentet den godt!

\section{Kilder og Referanser}

Viktig kildemateriale er hentet i arkivene til NKKM, De Sandvigske Samlinger og Kulturminnerådets arkiv i Riksarkivet. Videre er det referanser til:

Brøgger, A. W.: Fortidsværn og folkemuseer. Aftenposten 17. juli 1914

Brøgger, A.W.: Tale ved aarsmøtet i Bergen, sept. 1920. I Museumsarbeidet 1919-20, Foreningen til Norske Fortidsminnesmerkers Bevaring Arsberetning 1921, s. 250-253

Buggeland, Tord og Ågotnes, Jakob: Maihaugen, De Sandvigske Samlinger 100 år. Oslo 1987

Espeland, Velle: Desentraliseringsstriden. Tradisjon 4,1974, s. 71-76

Gjestrum, John Aage: Fra folkemuseum til økomuseum. Heimen $1 / 1993$ s. 30-45

Gustafson, Gabriel: Landsmuseer og Bygdemuseer. Verdens Gang 16. des. 1901

Innstilling om de halvoffentlige museers virksomhet og drift. Fra Museumskomitéen 1967. Bergen 1970 Lindberg, Ernst-Folke: Gunnar Hazelius och Nordis-

ka museets installationsfråga. Rig 1957, s. 65-115 Noss, Aagot: Norske Kunst- og Kulturhistoriske

Museer 60 år. Museumsnytt 2/1978, s. 51-67

Rasmussen, Holger: Bernhard Olsen. Virke og Verker.

Kjøbenhavn1979

Shetelig, Haakon: Norske museers historie. Oslo 1944

St. prp. nr. l, hovedpost V 1912, Om bevilgning til

forskjellige videnskabelige, literere og kunstneriske

formaal, Kra. 1911 s. 3-22

Ågotnes, Jakob: Maihaugen - i nordisk perspektiv.

Maihaugen Arbok 1993, s. 8-27

Aall, Hans: Beretning om en av ham efter Kirkede-

partementets anmodning foretagen undersøkelse

av forholdene ved enkelte museer sommeren

1911. I St.prp. nr. 1, 1912, Kra. 1911 s. 72-73

\section{Note}

- Texten publicerades ursprungligen i Museumsnytt 1993/2 med ingressen:

Vore museumsmand er et meget trattekjart-eller kanskje rettere - kampglad folkefard. Paa deres aarsmøter utkjampes der gjerne en rakke tvekampe saavel som storre bataljer, der mere end én gang har tjent til at forlyste offentligheten. Denne gang har de imidlertid foretrukket at vaske sit skidne tøi for lukkede døre.

Slik innleder hovedstadsavisa Tidens Tegn sin omtale av det aller første årsmøte i "Norske Museers landsforbund" i 1918. 


\section{FRA FOLKEMUSEUM TIL ØKOMUSEUM}

\section{Økomuseumsbegrepet - en fornyelse av museumsinstitusjonen og et viktig instrument for lokalsamfunnet ${ }^{1}$}

\section{John Aage Gjestrum}

Sett i forhold til det store tallet på museer i Norge, og deres viktige rolle $i$ et desentralisert kulturbilde, er museene i ubetydelig grad gjenstand for oppmerksombet, - hverken $i$ massemedia eller i kulturforskningen. Inad i museumsprofesjonen er det også i liten grad diskusjoner om museenes rolle. Denne situasjonen er heller ikke spesiell for Norge.

Gjennom 1970- og 80-tallet har økomuseene vært uttrykk for en fagkritikk, og for nye måter å se museumsinstitusjonen på. Dette museumsbegrepet ble lansert i Frankrike, og er idag virksomt over store deler av verden. Denne artikkelen vil gi en presentasjon av økomuseumsbegrepet og perspektiver knyttet til det. I den norske kultursituasjonen har $ø$ komuseumsbegrepet vært et viktig element $i$ en utvidelse av museenes rolle.

I et utdrag fra artikkelen "Letter from Gratangsbotn" av Kenneth Hudson i et engelsk museumstidsskrift (1991), kan vi lese:

For noen få år siden ble det bygd et museum for båter og kystkultur her, men navnet skjuler virkeligheten, for det en faktisk finner er en type norsk økomuseum. Det er en ny bygning med båter og utstillinger som illustrerer livet til det barske folkeferdet som fant sitt levebrød rundt fjorden og langs kysten. Under samme tak er lokalarkivet, med en fast historiker til å se etter det. [...] og en varm morsom kafé. Det er, kan en si, ikke så mye et museum som en klubb med historisk og kulturell tendens. Det så for meg ut til å passe perfekt til lokalsamfunnets behov. Eller nesten perfekt, for museet består av mer enn bygningen. Det er, for å yte det full rettferdighet, senteret i et nettverk av lokalhistoriske severdigheter, kraftsenteret i Gratangsbotns kampanje for å bevare og formidle de gjenværende bevis av sin historie, - båtbyggerier, båter, brygger, lagerbygninger, butikker og bolighus, spredt langs fjorden over en avstand på kanskje ti mil. Museet er selv formelt ansvarlig for å ta vare på disse severdighetene og for å presentere de for publikum. ${ }^{2}$

Når Hudson bruker betegnelsen økomuseum på Gratangen Båtsamling, er det nettopp fordi museet har brutt gjennom "veggene", og blitt et redskap for bevaring og stedsforståelse i hele lokalsamfunnet. Et år seinere skriver Hudson en kritisk artikkel. "Drømmen og virkeligheten", der han diskuterer 20 år med økomuse- 
34 er, og spesielt de franske økomuseene. Han forteller han har besøkt en lang rekke museer i Europa som har valgt å kalle seg økomuseer, "og jeg har svært blandede følelser for det jeg har hørt og sett. "Likevel”, sier Hudson, "har det vært oppmuntrende å komme over museer som får til mer enn de hadde gjort, hvis de var fornøyd med å kalle seg friluftsmuseer. Navnet 'økomuseum' har gitt de et mål å forsøke å leve opp til, sjøl om det målet bare delvis er realiserbart." ${ }^{3}$

\section{EN OKONTROLLERT FRAMVEKST AV MUSEER}

I Norge er vi i starten på 1990-tallet vitne til en "museumsboom" vi neppe tidligere har sett maken til. Dette gjør det aktuelt å rette søkelyset på museene nettopp nå. Mens vi tidligere i etterkrigstida kunne ha en økning på 5-10 nye museumstiltak pr. år, viser de siste år en eksplosjonsartet økning. I offisielle oversikter er økningen fra 1990 til 1992 på hele 230 museer og samlinger. Det betyr at det $i$ Norge idag etableres to nye museer pr. uke! ${ }^{4}$

Det er neppe å ta sterkt i å karakterisere dette som en "ukontrollert utvikling". Institusjonen "Norsk Museumsutvikling" ble etablert i 1992 som kulturdepartementets tiltak for å styrke en sentral og statlig innflytelse over museene. Men det gjenstår ennå å se om dette prosjektet vil lykkes. Tidligere har nemlig slike tiltak basert på mange av de samme målsettinger, vært prøvd adskillige ganger i Norge: etablering av en landsplan for museer i 1947 (aldri gjennomført), opprettelse av Statens Museumsdirektør 1953 (nedlagt 1961), statlig tilskuddsordning for halvoffentlige museer 1975 (delvis avviklet 1983), opprettelse av Statens museumsråd 1979 (nedlagt 1991).
Den ukontrollerte norske museumsutvikling er imidlertid ikke noe nytt. Da vi på slutten av 1800-tallet fikk de første folkemuseene, skrev i 1901 professor Gabriel Gustafson ved Universitetets Oldsaksamling i en avisartikkel at "Hva der først og fremst gjelder er Norges kulturhistorie, ikke Setesdalens eller Gudbrandsdalens". Han argumenterer sterkt for at alle må støtte opp under det nye Norsk Folkemuseum, så det "snart og i stort kan vise oss det norske folk i bilder fra bygd og by." Og skulle det ikke lykkes å få alt samlet i ett museum, "saa lad det blive Østlandet og Vestlandet og Nordlandet hvert paa sit Sted. Tre eller fire Landsmuseer kan endu lade sig høre, men hundrede - umuligt."5

Professor Gustafson kom altså til å ta feil, ja grundig feil i dette. Det er altså ikke bare blitt hundre, men ifølge Norsk Museumsutvikling nå i Norge totalt 777 store og små samlinger og museer. Stikkprøver viser også at oversikten på langt nær er komplett, slik at det virkelige tall muligens ligger et sted mellom 800 og 1.000. Det må imidlertid sies at Norsk Museumsutvikling her bruker en vid definisjon på hva "museer og samlinger" er.

Museer har i lang tid vært verdsatt på grunn av sin fortidighet. Det at de kan forevise antikvariske samlinger fra ei fortid som er forbi, som ikke lenger angår våre virkelige liv idag, men som kan være pittoreske påminnelser om hvilket fantastisk framskritt vi har vært med på gjennom modernismens tidsalder. Museumsboomen i Norge i dag synes mer å relatere seg til at museene også inngår i en nåtidig virkelighet, som kulturinstitusjoner i lokalsamfunnene. Faktisk er ca. 85\% (658) av museumstiltakene av lokal og regional karakter. ${ }^{6}$

Når vi vil sette søkelys på museene rolle idag, må vi imidlertid først se på trekk fra deres historiske utvikling. 
FRA NASJONENS "FOLK" TIL LOKALSAMFUNNETS "BEFOLKNING"

Ved museene i Norge og ellers i Norden er folkemuseenes framvekst og betydning et hovedtrekk. I Norge fikk de sin betydning da konstruksjonen av et nasjonalt innhold $\mathrm{i}$ 1800-tallets nye norske stat ble en hovedoppgave. Ja, disse museene ble på mange måter templer for nasjonalsymbolene.

"Har nasjon - trenger kultur!". Slik setter etnologen Brit Berggreen situasjonen på spissen, når hun viser hvordan romantikkens "folk"-begrep var synonymt med bonden, som i idealisert versjon ble nasjonalsymbolet. I de mest avskjermede dal- og fjellbygder fant altså bybefolkningen og øvrige kondisjonerte "de andre", folket. ${ }^{7}$

Fra midten av 1800-tallet kom "folke-livet", altså bondekulturen, i sentrum for billedkunstnere, forfattere og etterhvert forskeres oppmerksomhet. Museumsfolkene kom smått om senn også inn på banen og ble entreprenører for folkemuseene. At innlandets bondekultur egentlig ikke var så almengyldig, ble ikke oppfattet som problematisk. Dette på tross av at størstedelen av Norges befolkning levde ved kysten, der fiske, sjøfart og handel spilte en kanskje større rolle enn jordbruket Kystkulturen måtte på grunn av sin åpne kontakt med omverdenen pr. definisjon være mindre nasjonal enn bondekulturen i innlandet.

HelIer ikke kongen, Oscar II, stod tilbake for noen i å følge tidens nasjonale begeistring for bonden. Han etablerte med god hjelp av sentrale norske kulturminnevernere på 1800tallet, verdens første friluftsmuseum på Bygdø. Da hadde både Artur Hazelius i Stockholm og andre allerede startet å samle inn folkekunst-gjenstander fra norske bygder.
Med Oscar II.s bygningssamling som forbilde, startet Artur Hazelius innsamlingen av bygninger til sitt Skansen i Stockholm (1891) og Anders Sandvig sine bygningssamlinger ved den nyanlagte jernbanestasjonen på Lillehammer (1894). Få år seinere var Norsk Folkemuseum etablert pa Bygdøy som det museet som skulle vise hele den norske nasjonalkultur. ${ }^{8}$

Begrepene folkemuseum og friluftsmuseum er i stor grad blitt brukt om hverandre, og i stor grad forstått som det samme: en utvalgt samling av originale bygninger med tilknytning til folkelige samfunnsklasser, - som vil si bønder, - blir flyttet sammen i en park, og innredet med møbler og inventar fra samme miljø. I den første tida var museumsskaperne mest opptatt av å vise ulike bygningstypers evolusjon. Seinere ble et mer funksjonalistisk synsett vanlig, der bygninger fra samme sted ble gruppert sammen i tun. De eldste folkemuseene stolte i utstrakt grad på rekonstruksjonsarbeid for å restaurere bygningene til deres opprinnelige tilstand. Resultatet av dette, sier dansken Kaj Uldall, er "ofte at den rekonstruerte bygning er en modell i full størrelse, - et resultat av en tolking, og ikke et historisk monument av primær kildeverdi". ${ }^{9}$

Istedet for at Norsk Folkemuseum ble det ene store og viktige museet over norsk folkekultur, ble dette museet og ikke minst Maihaugen (De Sandvigske Samlinger) gjennom friluftsmuseumsmodellen forbilde for nasjonalbevisste entreprenører over store deler av landet. I tiårene som fulgte ble det etablert mer enn 100 museer i Norge, nær alle av folkemuseumstypen (1900-10: 16,1910-20: 22, 1920-30: 37, 1930-40: 36). ${ }^{10}$

Det nasjonale spørsmålet var et politisk radikalt tema fram til det nådde et klimaks med sjølstendigheten fra Sverige i 1905. Det nasjo- 
36 nale temaet forsvant imidlertid ikke. Og museumsveksten kom nå i det nye politiske klima der en radikal arbeiderbevegelse stod for en antinasjonal og internasjonalt orientert politikk. Det ble den politiske høyreside som ivaretok det nasjonale. Nå ble det et viktig element i den politiske kampen mot arbeiderbevegelsen. Dette var situasjonen gjennom 1920- og 30-tallet. De norske folkemuseene må derfor idag forstås nettopp ut fra at de ble oppbygd og formet i en helt bestemt kulturpolitisk situasjon. ${ }^{11}$

Etter andre verdenskrig fikk det nasjonale tema et nytt innhold, - nå kunne det binde nasjonen sammen. Det er imidlertid folkemuseene skapt før krigen som utgjør de store og etterhvert også profesjonelt bemannede museene. Av nye museer ble det nå først og fremst etablert små bygdetun, men også de symboler på bondekulturen som nasjonalt hovedtema.

Tallet på museer og samlingenes størrelse vokste, og på 1960-tallet var museene mer eller mindre havnet $\mathrm{i}$ en krisesituasjon. De gamle museumsgründerne var borte, men etterlot seg enorme samlinger av bygninger og gjenstander. Et fătallig kollegium av museumskonservatorer måtte nokså mistrøstig konstatere at de manglet ressurser til å ta vare på samlingene. Det ble nedsatt en statlig utredningskomité i 1967, og på bakgrunn av dens innstilling (Hovekomitéen) kom en stortingsmelding "Om museumssaken" i 1973. Den resulterte i en statlig tilskuddsordning for museer, som var effektiv fra 1. januar 1975. Hovekomitéens definering av norske museer omfattet 260 institusjoner, som kunne deles $\mathrm{i}$ to grupper: folkemuseer og spesialmuseer. Av i alt 203 folkemuseer var 191 lokale/regionale, av 57 spesialmuseer var 40 svært små. ${ }^{12}$

Tilskuddsordningen i 1975 kom samtidig med den generelle desentralisering av norsk kulturpolitikk. Fylkeskommunene ble tillagt oppgaven å sette øvre rammer på museumstilskuddene. I flere år framover (til 1983) ga dette museene en kraftig tilskuddsvekst. En lang rekke museer som tidligere ikke hadde hatt bemanning, fikk nå faste stillinger. Ettersom flesteparten av museene var av folkemuseumstypen, er det antakelig en riktig hypotese at museumsmønsteret fra mellomkrigstida nå ble ennå mer befestet enn det hadde vært. Det er derimot ikke gjort noe forskning omkring dette, - i likhet med de fleste andre viktige spørsmål om museenes utvikling $\mathrm{i}$ Norge.

Situasjonen hadde imidlertid to klare konsekvenser som er viktige i forhold til vårt tema: Først at de nye økonomiske betingelsene førte til at det på svært få år ble ansatt et stort antall fagkompetente konservatorer også på de mellomstore og mindre museer rundt omkring i landet, der det tidligere ikke hadde vært slike stillinger. Disse tilhørte en generasjon som ble utdannet i "den grønne bølgen” først på 1970-tallet, og var lite bundet til mange av det norske museumsvesenets nedarvede konvensjoner. Dernest tydeliggjorde den nye økonomiske satsingen på museene, som kom samtidig med den nye kulturpolitikkens vekt på desentralisering, egenaktivitet og kulturelt demokrati, - likevel uten at noen av disse målsettingene var innbakt i den offisielle museumspolitikken, - hvor smale og lite dekkende folkemuseene egentlig var i forhold til norsk kulturhistorie. Dette gjorde at mange så nødvendigheten av å sette igang innsamlings- og bevaringstiltak knyttet til andre typer kulturarv. Etterhvert kunne vi derfor se oppstarting av museumstiltak knyttet til kystkulturen, industriminner og arbeiderkultur, og etniske minoriteter som først og fremst i 
Norge i museumssammenheng har vært den samiske kultur.

Det er flere viktige innfallsvinkler når vi skal se nærmere på økomuseumsbegrepet. Disse knytter seg til ulike fagtradisjoner. Den største faglige utfordringen i økomuseumsarbeidet er å integrere disse i synteser knyttet til lokalsamfunnet. Vi skal her trekke fram to perspektiver der begge er grunnleggende for økomuseumstenkningen; - forståelsen av menneskets forhold til de nærmeste avgrensede geografiske rom og menneskets behov for historisitet.

\section{RoMdimensJon OG STEDSTAP}

Økomuseets idé er knyttet til menneskers behov for å kjenne og forstå det sted der de kanskje tilbringer mesteparten av sitt arbeidsog sosiale liv. Bare ved slik forståelse kan enkeltmennesket ta stilling vis-à-vis fortida og de prosesser som har påvirket stedet og menneskene der. Ved å ta posisjon utvikles grunnlag for fellesskap og samhandling, for at menneskene kan bli aktører i verden, ikke bare tilskuere.

Hjemstedet i det moderne industrisamfunnet har for mange først og fremst vært oppfattet som et sted stadig å reise fra, i tråd med målsettinger om optimal mobilitet. Det har derfor vært ønsket å knytte "irrasjonelle" følelser, nostalgi og romantikk til hjemstedet, mer enn empiri og faglige begrunnelser.

En forsker som har brutt med den overflatiske likegyldigheten omkring hjemstedets betydning og det å bo, er arkitekturprofessoren Christian Norberg-Schultz. Han vektlegger sammenhengen mellom det å kjenne et sted, hvordan denne tilhørigheten på samme tid er noe helt personlig knyttet til individet, samtidig som stedet oppleves som noe en har sammen med andre, og som derved blir grunnlag for felleskap eller samfunn. $\AA$ bo er derfor kvalitativt sett noe langt mer enn materielle og kvantitative spørsmal, slik vi kjenner det fra moderne planlegging og etterkrigstidas husbanknormer:

Det å bo i denne kvalitative forstand er et grunnleggende trekk ved det å være menneske. Det er først og fremst gjennom identifikasjon med et sted at vi vier vårt liv til en bestemt slags tilværelse. Derfor krever det å bo både noe av oss selv og av våre steder. Vi må ha et åpent sinn, og stedene må være slik at de byr på rike muligheter for identifikasjon. I dag er mange steder fattige og mange sinn lukket, og det er blitt vanlig å snakke om en omverdenskrise. ${ }^{13}$

Norberg-Schultz kaller dette stedstap. Tidligere hadde stedene en tetthet som skilte dem fra omgivende land. Det var lett å orientere seg omkring hvor en var. Opplevelsen av stedet er så knyttet til stedets romstruktur, til horisontale og vertikale retninger og begrensninger. "Horisontalen omfatter alle de 'rytmer' som utgjør dagliglivet på jorden, mens vertikalen representerer en 'spenning' som går ut over det jordiske", sier Norberg-Schultz. Stedets karakter er så helhetsopplevelsen av dette, måten elementene sammen danner et landskap. Når vi bor, må menneskene for å få fotfeste i tilværelsen nettopp åpne seg for omverdenens egenart, å respektere og bli venner med omgivelsene. ${ }^{14}$

Den kinesisk-amerikanske geografen $\mathrm{Yi}$-Fu Tuan la i 1974 fram sitt begrep topofili: av gresk topos - plass og filos - venn. Topofili berører derfor menneskets stedsbundethet, knyttet til følelsesmessige, viljemessige og fornuftsmessige bånd. ${ }^{15}$

I den følelsesmessige tilknytningen til et sted, som ofte kan være hjemstedet, ligger motiveringer for å ta vare på kultur og natur 
38 på dette stedet. Noe som ofte vil stå i kontrast til modernismens rasjonalitet, der naturen er råstoff for produksjonen og der evt. "verneverdige" deler av kultur og natur som kommer $\mathrm{i}$ veien, kan bringes til redning på egnede, nødvendige reservater.

Et annet begrep som kan brukes i denne sammenheng er territorialitet - som knytter seg til hvordan mennesket forstår rommet, det landskap det lever i. Mens territoriet er et nøytralt geografisk begrep, kan territorialiteten sees som de idéer, den mentale forståelse menneskene $\mathrm{i}$ et område har om forholdet mellom seg og sitt territorium. Denne territorialiteten vil idag være kvalitativ målt ut fra hvorvidt menneskenes og lokalsamfunnets forståelse vil føre til en ødeleggelse av det framtidige livsgrunnlag eller en bevaring av det.

Sagt på en annen måte: en følelsesmessig og kunnskapsmessig bevissthet og nærhet til et sted, den plass en bor på, vil antakelig være viktig for å etablere økologisk ansvarlige handlinger. Territorialiteten uttrykker noe om forholdet mellom menneskene og moder jord.

\section{Tidsdimensjon OG HISTORISITET}

Mens tredimensjonalitet er en måte den fysiske verden oppleves på i et bestemt tidsøyeblikk, er den fjerde dimensjonen tiden. Det er ved å se "firedimensjonalt" at en ser et sted slik at også endringsprosesser inngår i karakteristikken. Den engelske forskeren Kevin Walsh peker i ei nyutkommet bok om museenes presentasjon av fortida, på hvor viktig det er å slå fast at det ikke er noen ontologisk forskjell mellom fortida og nåtida. Om vi anser vår nåtid som kontinuerlig å bli konstruert i "fortida" eller alltid i "nåtida", er ikke det avgjørende. Det viktige er at vi innser at endringsprosessene gjennom tid og rom er kontinuerlige, og at studiet av og bevisstheten om ens eget nåtidige sted ikke er forskjellig fra studiet av dets fortid. ${ }^{16}$

Mens folkemuseet gjerne viser ei generalisert og "fjern" fortid, presentert som et statisk og konstruert kunstig bilde, vil økomuseene med bevaring av bygninger og anlegg $\mathrm{i}$ sitt opprinnelige miljø være pluralistiske og vise flere "ekte" situasjoner og fortider. Dette vil også gi historisk dybde til langt flere steder, ettersom de historiske minnesmerker også inngår i det nåtidige landskap, og ikke som ved folkemuseene der historien er reddet "ut av den nåtidige virkeligheten" og satt inn i det kunstige "reservatet" museet utgjør.

Det er ikke vanskelig å finne også andre bevis på det behov menneskene har for historisitet, og der dette er noe annet enn vitenskapsmenns behov for å "redde" kunnskapen om fortida.

Et viktig eksempel i Norge finner vi i de gards- og slektshistoriske bygdebøkene. Fra en forsiktig start først på 1900-tallet skrives det i Norge etterhvert mer enn 800 bind gards- og slektshistoriske bygdebøker. Dette er et gigantisk prosjekt der landet forstås i "genealogiske regioner" ofte definert i tråd med gamle sognegrenser, og hver eneste gard og slekt følges generasjon for generasjon gjennom århundreder. Det er utgitt omkr. 600.000 sider slik slektshistorie. Det "norske lokalsamfunnets røtter" er derfor solgt som litterær "bestselger" i et opplag pa nærmere 2 mill. bøker! I økonomisk satsing representerer dette "prosjektet" bare gjennom 1970- og 80-tallet en satsing på antakelig mer enn 600 millioner kroner. ${ }^{17}$

En forsiktig formulering er å si at det har vært en viss ambivalens overfor dette "prosjektet" på sentralt faglig hold. For sjøl om en stor del av bøkene er skrevet av faghistorike- 
re, må det virkelig kunne reises tvil om all denne oppsamlingen av genealogi kan tilføre noe historisk kunnskap. Som historikeren Steinar Imsen sier i anmeldelsen av ei gardsog slektshistorie i 1975, er dette å skrive historie på samme måte "som å beskrive en maurtue ved å ta for seg hver maur og hver barnål". ${ }^{18}$

Det viktige for historikeren er å finne ut ny kunnskap om historia, å se sammenhenger og oftest vektlegge det som er "rikshistorisk" interessant. Den samme historikeren vil imidlertid kunne ha liten evne til å forstå at for enkeltmennesket i si bygd, er det ikke akkumuleringen av ny historisk kunnskap som er verdifull, men etableringen av en historisitet, - av sjøl å være i historia, i en sammenheng mellom det som var, det som er og det som skal bli.

I studiet av kulturvern og museer i Norge er spenninger mellom ideologier knyttet til de nasjonale spørsmål og ideologier knyttet til lokalsamfunnene et viktig tema. I visse deler forenes disse ideologiene, i visse deler står de i motsetning til hverandre. Dette er et tema som burde invitere til en betydelig forskningsinnsats. Sosialantropologen Arne Martin Klausen går så langt som å si at i Norge synes vektleggingen av smådimensjonerte samfunn og regional identitet å stå sterkere enn nasjonalismen og dens politiske ideologi. ${ }^{19}$

\section{Tradisjonelle MUSEer I KRISE - ØKOMUSEET SOM ALTERNATIV}

Det er et dominerende inntrykk at museene har hatt store vansker med paradigmeskiftet $\mathrm{i}$ vår tid. På et visst tidspunkt ble det klart for svært mange at det rasjonelle og framskrittsrettede "modeme" industrivekst-samfunnets suksess hadde ei bakside i form av ensretting og ødeleggelse av menneskets miljø, med trussel om økologisk sammenbrudd. Konsekvensen av de nye helhetsperspektiver på vår sivilisasjon som dette frambringer, må vi kunne betegne som et paradigmeskifte.

I Norge fikk dette tidlig aktualitet, - først og fremst gjennom det markerte økofilosofiske miljøet, som fra omkr. 1970 fikk stor innflytelse. De første store miljøkonfrontasjonene og ikke minst politiseringen fram mot folkeavstemmingen om EF i 1972, plasserte økopolitiske og økofilosofiske spørsmål sentralt i norsk intellektuell og politisk debatt. ${ }^{20}$

Museene hadde imidlertid tjent modernismen, og, som vi allerede har sett, oppbygging og vedlikehold av 1800-tallets nasjonskonstruksjoner. Dette skjedde i hvert land gjennom bevegelser som trengte samlende nasjonale symboler, - og fikk det. I tillegg ble museene rask institusjonalisert og profesjonalisert, slik at sjølopprettholdelse snart tok mesteparten av ressursene. Museene ble gjenstandsrettet og ikke menneskerettet. Etterhvert som likeverdbevegelsen (sosialismen), antikrigsbevegelsen og den økologiske bevegelsen kom til, hadde derimot museenes innhold og ideologi allerede i sterk grad vært definert og "opptatt".

Mot slutten av 1960-tallet var det erkjent i mange land at museene hadde kommet i ei krise. Løsninger på dette ble prøvd ut gjennom satsing på å skaffe mer penger til museene, gjennom ny arkitektur og mer offensive formidlingsteknikker brukt på det "gamle" innholdet, - ny teknologi som audiovisuelle media, osv.

En annen innfallsvinkel var en omdefinering av museumsinstitusjonens karakter. Som direktør for ICOM (det intemasjonale museumsforbundet knyttet til Unesco) stod Hugues de Varine omkr.1970 for initiativet 


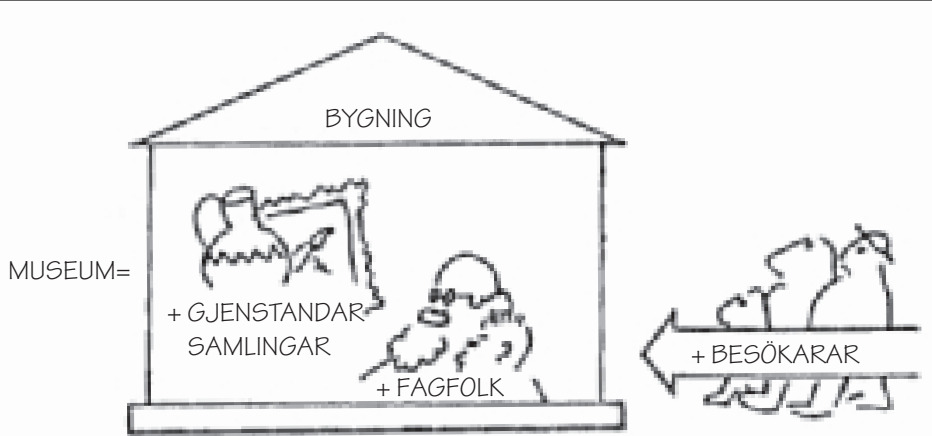

Fig. 1. Det tradisjonelle museet:: Et udefinert "publikum" besøker ei "passiv" samling med hus eller ting (René Rivard, 1984).

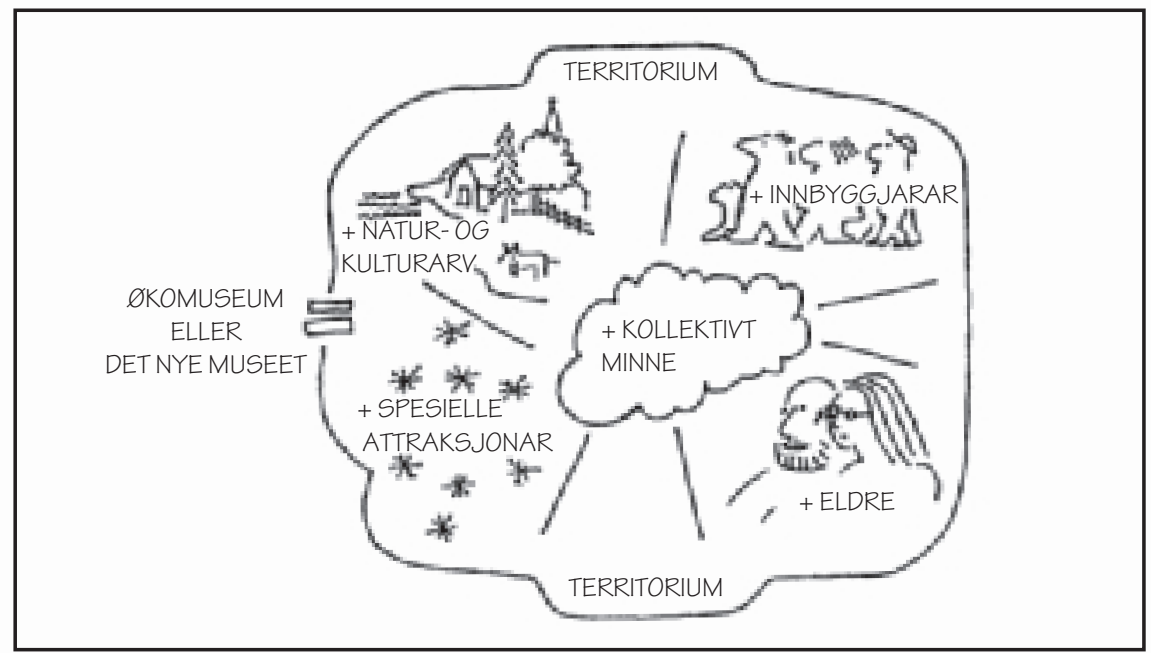

Fig. 2. Økomuseet: Hele området er en enhet av natur og kultur (Renè Rivard, 1984).

til flere av de viktigste tiltakene som søkte å fornye museene, og å gi de nye roller i den aktuelle samfunnssituasjon. Dette var f.eks. Santiago-konferansen i Chile 1972, der museets sosiale rolle i Latin-Amerika ble institusjonalisert i konseptet for det "integrerte museum”. I Latin-Amerika var kanskje kontrasten mellom den sosiale virkelighet og museenes rolle som underholdning for en liten, men mektig økonomisk og politisk elite, mer tydelig og brutal enn noe annet sted. Vi fikk altså her en fokusering på utfordringene 
overfor likeverds-prinsippet. Etableringen av "neighbourhood museums" i USA var også viktig i dette perspektivet.

Økomuseene i Frankrike skulle allikevel bli det som tydeligst fokuserte museenes inntreden i den nye miljøalderen. Ordet økomuseum ble formulert av Hugues de Varine i 1971 i forbindelse med den nye franske miljøvernministerens tale til ICOMs generalforsamling i Grenoble. Innholdet var imidlertid allerede gradvis utprøvd i George Henri Rivières eksperimenter i franske regionparker. I sin definisjon av økomuseet sier Rivière bl.a.:

Et økomuseum er et instrument etablert, formet og drevet i fellesskap av en offentlig myndighet og en lokalbefolkning. Den offentlige myndigheten er involvert gjennom å yde eksperter, anlegg og ressurser; lokalbefolkningens involvering bygger på dens målsettinger, kunnskaper og individuelle holdninger. ${ }^{21}$

I Frankrike ble økomuseumsbevegelsen på 1970-tallet et kraftig uttrykk for en museumskritikk, og en rekke økomuseer ble til. Lokalbefolkningen som aktør i nåtida innenfor et avgrenset territorium, stod i sterk kontrast til de "gamle" museenes generelle budskap til et ikke-definert og anonymt publikum. (Se fig. 1 og 2 ved René Rivard).

Økomuseene er ikke alene opptatt av økologiske vernespørsmål, sjøl om mange økomuseer er utviklet som et resultat av bevissthet om slike tema innenfor lokalsamfunnene. Det som er typisk er imidlertid integreringen av alle fag som bidrar til forstålse av mennesker og steder. Hugues de Varine oppsummerer funksjonene til dette lokalsamfunnsmuseet som firedelt: (1) å være databank både for de kunnskaper lokalsamfunnet trenger idag og de det vil trenge i framtida, (2) à tjene som observatorium, altså et vitne til endringer som stadig skjer, og som lokal- samfunnet kan gripe inn i hvis de får kunnskap om hva som skjer, (3) å være et laboratorium der en kan eksperimentere med mulige samfunnsløsninger, med positive endringer, og (4) å være et utstillingsvindu, der en kan "vise sine skatter fra fortida, sin bekymring om nåtida, sine planer og prosjekter for framtida". 22

Vi finner også mange lokalmuseer som ikke er økomuseer. Noen vil hevde at de fyller samme rolle. Det er imidlertid viktige forskjeller her. I de fleste tilfeller er lokalmuseet fylt med samlinger uten kontekst, og som ikke kan belyse historiske prosesser. De er ofte uten kontakt med lokalsamfunnets demokratiske fora, og representerer gjerne svært eksklusive grupper. ${ }^{23}$

Når økomuseumsidéene ble formulert, og raskt fikk stor oppslutning i Frankrike, skyldtes det ikke minst at Frankrike har hatt det mest sentraliserte av Vest-Europeiske forvaltningsstrukturer. På slutten av 1960-tallet med 1968-våren som klimaks, ble det tydelig at en desentralisering var nødvendig. Økomuseene bidro med kulturelle dimensjoner til denne prosessen, i sterk kontrast til de eksisterende elitepregede kunstmuseene som hadde fullstendig dominert det franske museumsbildet. Økomuseumstankene kom gradvis også inn i andre land, som f.eks. Québec (den fransktalende del av Canada), Portugal, Spania og etterhvert også i Skandinavia. Idag er det over hele verden ca. 90 museer med økomuseumsbetegnelsen i navnet, men et mangedobbelt tall av museer som arbeider i tråd med $ø$ komuseumskonseptet under navn som $m u$ seo communtaire, community museums, - lokale og regionale museer. Museenes karakter er imidlertid viktigere enn bruken av ordet økomuseum. ${ }^{24}$ 
Norske museumsfolk som deltok i arbeidet til den internasjonale og Unesco-tilknyttede museumsorganisasjonen ICOM, tok med seg $ø$ komuseumsbegrepet til Norge fra konferansene om "Museum and Environment" som ICOM arrangerte flere av først på 1970-tallet. $^{25}$

I 1976 holdt Hugues de Varine foredrag på en internasjonal museumskonferanse $\mathrm{i}$ Umeå/Skellefteå i Sverige, der han snakket om nødvendigheten av å fornye museumsinstitusjonen. Som konklusjon foreslo Hugues de Varine at det skulle opprettes en pilot-museumssektor i hvert land, som kan stå for forsøksvirksomhet og være et pedagogisk redskap for museumsmedarbeidere og for offentligheten. ${ }^{26}$

En av de få deltakerne fra Norge på CECAkonferansen i 1976 var Marc Maure. I Museumsnytt presenterte han erfaringene fra den eksperimentelle virksomheten ved Anacostia Neighborhood Museum (USA), økomuseet i Le Creusot (Frankrike), Skellefteå Museum (Sverige) og Riksutställningars regionala verksamhet (Sverige). Maure sorterer det originale og verdifulle med disse eksperimentene $\mathrm{i}$ tre hovedaspekter: (1) Kulturelt demokrati, (2) økologisk/tverrfaglig perspektiv, og (3) altemativ/"frigjørende" pedagogikk. Han peker på muligheten for å åpne en ny type dialog mellom fagmann og almenhet:

"Ekspertene" fungerer nærmest som en slags "katalysator"; deres rolle blir først og fremst å legge forholdene til rette, å gi befolkningen mulighet til å bli bevisst sin egen situasjon i forhold til utenverdenen, og videre til å uttrykke seg.

Alle de kunnskaper som lokalsamfunnet på denne

måten erverver seg, om sin kultur, sine omgivelser, sin historie osv., gjør at det får bedre kontroll over sin egen tilværelse og mulighet til å påvirke sin egen situasjon. ${ }^{27}$

Etterhvert ble flere norske museumsfolk nysgjerrige og fant veien til de franske økomuseene. Først og fremst ble det internasjonalt sterkt fokuserte "Museet om mennesket og industrien" i Le Creusot besøkt. Sammenhenger mellom det franske økomuseumsbegrepet og museumstanker i Norge ble etterhvert tydelige for flere. Norske museumsfolk deltok i samtalene omkring dannelsen av en ny internasjona1 bevegelse for "ny museologi" (1983), og seinere ble organisasjonen MINOM (International Movement for a New Museology) etablert. ${ }^{28}$

I mars 1984 arrangerte Norsk ICOM sammen med kulturseksjonen ved Telemark distriktshøgskole seminaret "Økologi og identitet; nye veier i museumsverdenen". Seminaret samlet mer enn 60 deltakere, som fikk møte to franske museumsfolk: Alain Joubert fra Ecomusée de la Basse Seine og André Desvallées fra Inspection Général des Musées de France. Samtidig ble 6 norske museer presentert i perspektiv av økomuseumsbegrepet. Nå skjedde det som ikke hadde skjedd i Norge på 1970-tallet, sjøl om altså økomuseumsbegrepet var kjent da: økomuseumsidéene ble knyttet til konkrete norske museumserfaringer. For mange av deltakerne på seminaret $\mathrm{i}$ 1984 ble dette en "aha-opplevelse"; - ut fra den lokale situasjon og "naturlige" arbeidsmåter var museumsarbeidet i mange norske lokalsamfunn de seinere åra utviklet helt annerledes enn de tradisjonelle folkemuseer. For første gang møttes museumsfolk fra hele landet som hadde prøvd å arbeide "annerledes". Som Steinar Wikan, en av deltakerne på seminaret skrev etterpå: 
Stikkord som helhet, deltakelse, desentralisering og variasjon har hele tiden vært sentrale begreper i utviklingen av vårt museum. Det ble bare slik fordi en ikke fikk til å sentralisere museumsengasjementet i kommunen.

Tidligere var det litt pinlig når folk som ikke kjente vår struktur, spurte hvor Sør-Varanger Museum egentlig ligger. (Man venter seg et konkret bygg). Nå kan man svare at Sør-Varanger Museum er et økomuseum, og det skal ha en desentralisert profil. ${ }^{29}$

Drøftinger under seminaret og etterpå gjorde det klart at det var stor interesse for å etablere et samarbeid mellom museer som oppfattet grunnidéene i økomuseumstanken som viktige i sin museumsvirksomhet, og ei norsk samarbeidsgruppe av økomuseer ble til.

Ved starten bestod "Gruppen av norske økomuseer" av 8 museer, fordelt på 7 fylker. En satte ei øvre grense på 12 medlemmer, dette "for å hindre at kommunikasjonen mellom medlemmene i gruppen blir for dårlig, og at den konsentrerte innsats vi bør stå for i etableringsfasen vil svekkes." 30

Gruppen ble etablert som en seksjon av NKKM, og fikk også etterhvert tilknytning til MINOM. På mange måter er det riktig å se etableringen av økomuseumsgruppa og arbeidet i gruppa de første åra, som knyttet nettopp til en slik pilot-prosjekt-preget forsøksvirksomhet som Hugues de Varine ønsket i 1976.

\section{FellestrekK \\ VED ØKOMUSEER I Norge}

De 12 museene som deltok i Gruppen av norske økomuseer fra 1984, var alle museer i en etablerings- eller sterk omdanningsfase. ${ }^{31}$ I dette lå naturlig nok en vesentlig del av motiveringen overfor det å ville prøve ut nye museumsidéer, og å gå inn i et faglig forum som økomuseumsgruppa. Det var også en nær sammenheng mellom disse museumstiltakene og det nye økonomiske grunnlaget for museumsdrift fra 1975 tilskuddsordningen for halvoffentlige museer ga. Et av de viktigste uttrykk for dette er at alle museene med unntak av ett ${ }^{32}$ fikk etablert faste fagstillinger etter $1975,-7$ av de 12 museene fikk sine fagstillinger først på 1980-tallet. Disse museene var likevel ikke etablert som økomuseer. Hver for seg var de etablert ut fra et eget grunnlag. Mange av tiltakene hadde vokst ut av lokalhistorie-prosjekter igangsatt i første del av 1970-tallet. ${ }^{33}$

Stikkordmessig har folgende trekk vart felles ved museene:

- en definerte museet som redskap i en identifikasjonsprosess, der en uttrykte en felles kulturpolitisk plattform i vektleggingen av forholdet mellom museum og befolkning

- museene arbeidet alle med å bygge opp integrert dokumentasjon: fotografier, lydopptak, arkivalia, gjenstander, bygninger

- et dokumentasjonssenter rommet "databanken" i hvert museum, gjerne kombinert med museets administrasjon og andre museumssenterfunksjoner. I dokumentasjonssenteret ble materiale befolkningen sjøl har registrert samlet, og det kan utforskes og brukes i undervisning eller lokalhistoriske publikasjoner. De fleste av museene publiserte årbøker

- et sterkt engasjement i vern av bygninger og anlegg i museets distrikt er knyttet til opprettelse av verneverdige anlegg som avdelinger (antenner). Gjennom drift av antikvarisk verksted bidro museene til bevaring av anlegg som ikke inngår direkte som avdeling i museet, men er en del av lokalsamfunnets kulturelle arv:

- de industrirelaterte museene var utviklet 
44 i forlengelsen av det arbeid som AOF (Arbeidemes Opplysningsforbund) og lokale fagforbund gjennomførte fra 1975 med arrangering av arbeiderkulturdager ulike steder i landet.

Da museumsorganisasjonene utga sin guide til norske museer i 1988, regnet de 20 museer i 10 fylker som økomuseer. ${ }^{34}$ Idag viser et forsøk på å gjøre en vurdering at omkring 40-50 museer og museumsprosjekter er knyttet til økomuseumsbegrepet. Riktignok uttrykkes dette ulikt i de ulike museer: Noen bruker ordet økomuseum i navnet på museet. Andre bruker det ikke i navnet, men i presentasjonen av museets karakter, - kanskje også i vedtektene, hvis museets faglige spesialisering er formulert. Andre igjen gjør mer uforpliktende bruk av økomuseumsbegrepet ved å si at museet drives etter økomuseumsmodellen, eller har hentet viktige impulser fra økomuseene. Spredt over hele Norge er nå økomuseumsprosjekter under utvikling. Museumstiltakene som de siste årene er vokst fram med tilknytning til arbeiderbevegelsen og arbeiderkulturen i industrimiljø, har alle tilknytningspunkter til økomuseumsidéene. ${ }^{35}$

En viktig observasjon er at økomuseumsmodellen synes å være et hovedkarakeristikum ved det regionale-lokale museumsarbeidet i hele Nord-Norge. Der var tradisjonelle folkemuseer ikke utbygd i samme omfang som i Sør-Norge. Mulighetene for museumsutbygging $\mathrm{i}$ og med med finansieringen fra slutten av 1970-tallet av, gjorde at en ønsket å finne nye veier. Vi kan egentlig kanskje si at økomuseene er blitt Nord-Norges folkemuseer. Dette inntrykket forsterkes ytterligere når en også ser på det samiske museumsarbeidet. Der finner vi kanskje den gruppe museer som er kommet lengst i retning av økomuseer i Nor- ge. Vi vil derfor se nærmere på det samiske eksempel.

\section{SAMISKe MUSEeR: OBJEKTS-MODEL- LEN OG PROSESS-MODELLEN}

De samiske museene definerer seg sjøl rett og slett som samiske museer, og bruker bare sjelden betegnelsen økomuseum. Museologisk sett må de på mange måter sees som økomuseer. Grunnen til at de har kommet så langt $\mathrm{i}$ å utvikle en ny museologi, ligger nødvendigvis i den avvisning de har måttet gjøre av de tradisjonelle museers arbeidsform, tydeliggjort slik de tradisjonelle museer har framstilt samekulturen. På MINOM’s 3. internasjonale arbeidskonferanse på Toten i Norge 1986, var det to temaer: "friluftsmuseet og økomuseet" og "minoritetene i de arktiske regionene". Mari Teigmo Eira kom fra Samiid Vuor'káDávvirat (De Samiske Samlinger) i Karasjok og holdt foredrag om det samiske museumsarbeidet. Da forelå alle 1980-tallets offisielle utredninger om den norske museumsstrukturen, og hun kunne fortelle at samtlige synspunkter samene hadde fremmet om sitt museumsarbeid og vern av kulturarv, hadde blitt ignorert. Og Teigmo Eira måtte si at det var dette som gjorde at hun tok den lange veien fra Karasjok til Toten, for å få støtte fra et internasjonalt museumsmiljø:

It is my wish that the Sami will be allowed to build up their own structures, and not weighed down by the lacks in the Norwegian structure. ${ }^{36}$

Mari Teigmo Eim representerer det nordsamiske språkområdet, og den største samiske befolkningsgruppa i Norge. Sørsamene er langt færre. For få år tilbake ble det reist alvorlige spørsmal om den sørsamiske kulturen i det hele tatt ville kunne overleve. Sig- 
bjørn Dunfjeld som leder det samiske kultursenteret i Hattfjelldal, sier at:

det en aller minst trengte var et museum. Å opprette et museum, ville være å stilltiende godta at sørsamisk kultur skulle bli en museumskultur.

En anså at museumsvesenet hadde funnet sin form tilpasset det norske samfunnet og dets behov, - en form som ikke passet i det sørsamiske samfunnet. Løsningen i Hattfjelldal ble da at de har etablert institusjonen Sijti Jarnge ikke "som et museum etter tradisjonelt mønster med konservering som en av basisoppgavene og en stor gjenstandssamling", derimot er andre museumsoppgaver definert som sentrale. "Vi ønsker å bidra til at vårt kulturlandskap med de merker det har etter årtuseners aktivitet i området skal pleies og bevares", sier Dunfjeld. ${ }^{37}$

Det de samiske miljøene gjør ved å erklære det tradisjonelle museumsbegrepet for å være for snevert, er imidlertid å utvikle nye modeller ut fra sin kultursituasjon og sine behov. I 1987 presenterte de samiske museer i Norge sin egen strukturutredning. Et av hovedspørsmålene for de samiske museene har vært å få aksept for en definisjon av hva et samisk museum er. Her har Nordisk samisk museumsutvalg satt opp ei liste på krav som må ivaretas; - det må være samisk styring både politisk og faglig, museet må være lokalisert i samisk strøk, i museets kulturhistoriske del må samekulturen være et hovedtema og belyst fra samisk synsvinkel..$^{38}$

Sørsamene er et lite folk, og spredt over et stort geografisk område. I Norge anslås det å være ca. 700-800 sørsamer, i Sverige et noe høyere antall. Saemien Sijte på Snåsa (NordTrøndelag) har hovedansvar for sørsamisk museumsvirksomhet. Museet kom i virksomhet i 1980 med to ansatte. I formålet for Sae- mien Sijte kan vi lese at en skal realisere planen om et sørsamisk kulturhus med samlinger av sørsamiske bruksting osv., men ved "siden av denne museale virksomhet skal Saemien Sijte arbeide med kulturspørsmål som er fremtidsrettet og som har som hovedhensikt å styrke sørsamisk identitet og fellesskapsfølelse" ${ }^{39}$ En naturlig konsekvens av dette har vært museets sterke engasjement i dokumentasjon og vern av samiske kulturminner i hele det sørsamiske området.

Det har vært gjort lite museumsteoretisk forskning i Norge med bakgrunn i erfaringene fra museumsarbeid etter nye idéer i 1980åra. Etter et års forskningsstipend har Sverre Fjellheim. som har vært konservator og leder for Saemien Sijte siden 1980, skrevet boka "Kulturell kompetanse og områdetilhørighet". Boka inneholder viktige oppsummeringer og analyser av 10 års erfaringer. Fjellheim viser dette ved å sette "objekts-modellen" og "prosess-modellen" opp mot hverandre som to helt ulike innfallsvinkler i samisk forskning og dokumentasjon.

Objekts-modellen (se fig. 3) er knyttet til den betydelige interesse "Skriftkultursamfunnet" (dvs. oftest det norske majoritetssamfunnet) har vist overfor samisk historie og kultur der det samiske samfunnet hele tiden har vært objekt og "råstoff-leverandør":

Når materialet er tatt inn i Skriftkultursamfunnet, går det gjerne inn i en bearbeidingsfase. Her kan materialet nærmest begynne å leve sitt eget liv gjennom analyse og fortolking av forskjellig art. Det samiske samfunn er nå helt uten innflytelse i prosessen, og uten muligheter til å f.eks. justere feiltolkinger.

Fjellheim viser hvordan materialet etter mer eller mindre omfattende bearbeiding så resulterer i produkter som forskningsresultat, undervisningsmateriell, politiske beslutninger, 


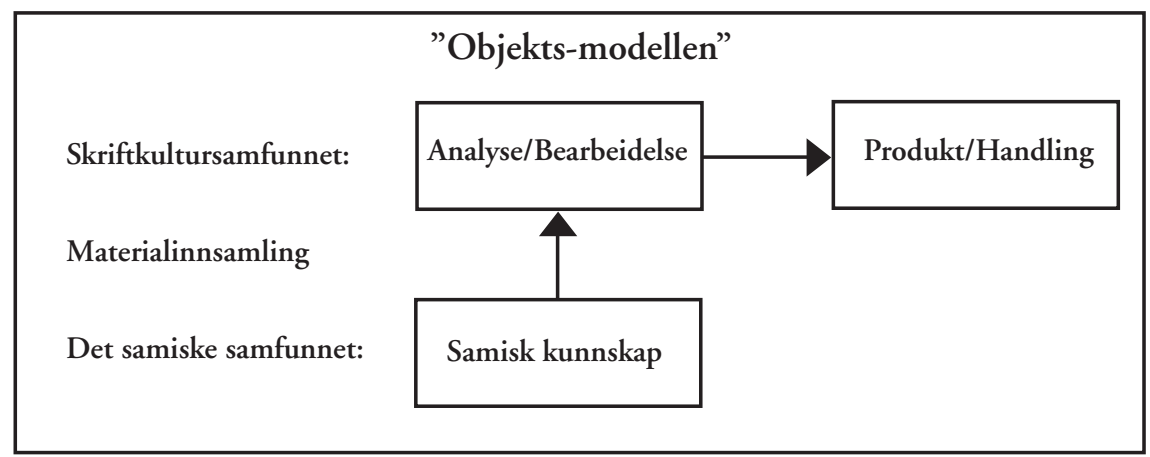

Fig.3. "Objekts-modellen" (Sverre Fjeldheim, 1991).

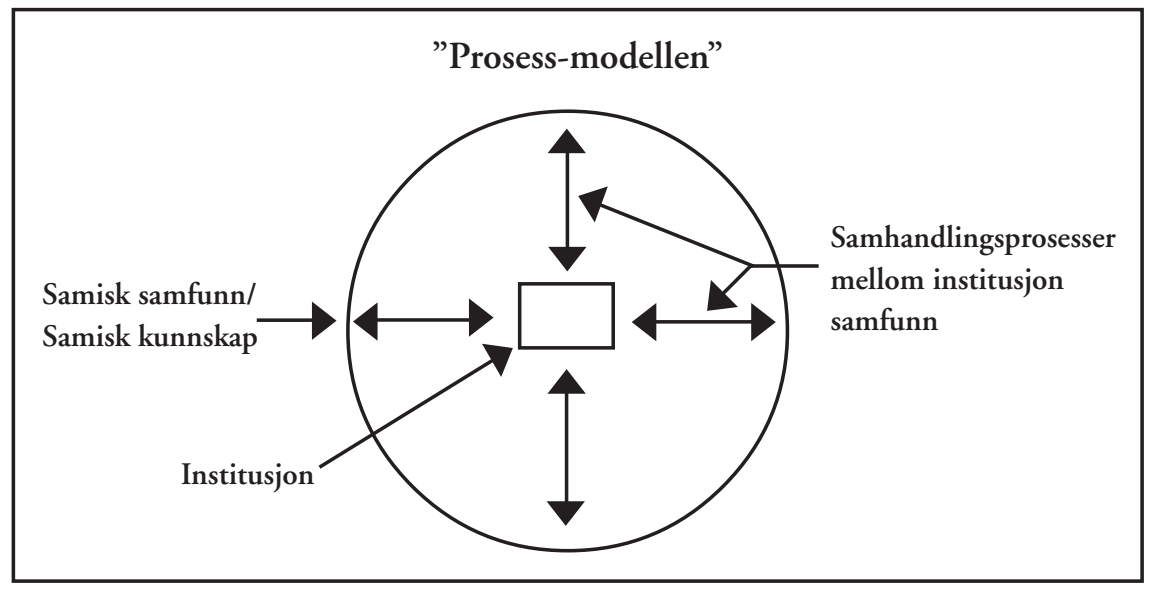

Fig. 4. "Prosess-modellen" (Sverre Fjeldheim, 1991).

lover osv. Og alt skjer her på Skriftkulturens premisser, og samene blir ennå mere spilt ut:

Som ett "biprodukt" av denne prosessen. kan vi få "sameeksperten" eller "same-eksperter" på ulike nivåer i Skriftkultursamfunnet. [-]

Disse "ekspertene" har dessuten ofte vært snarveien til informasjon og kunnskap om Det samiske samfunnet for det øvrige Skriftkultursamfunnet. De har ofte hatt lett spill, fordi det generelle kunnskapsnivået om Det samiske samfunnet generelt har vært svært dårlig.
Med bakgrunn i erfaringene bl.a. i faglig ledelse og koordinering av registreringen av 4.836 samiske kulturminner i alle de sørsamiske lokalsamfunn, utført av samene sjøl, legger Sverre Fjellheim fram det han kaller "prosess-modellen" (se fig. 4). Begrunnelsen bygger også på den nye "Sameloven" i grunnlovens paragraf 110 a: "Det paaligger Statens Myndigheder at lægge Forholdene til Rette for at den samiske Folkegruppe kan sikre og udvikle sit Sprog, sin Kultur og sit Samfundsliv": 
Dette kan vanskelig realiseres uten at samene sjøl deltar aktivt. Det kan heller ikke begrenses til at samer som enkeltindivider deltar i mer eller mindre tilfeldige sammenhenger. Samene er her naturligvis ment som folkegruppe. I praksis bør dette innebære at de engasjerer seg eller blir engasjert i praktisk kulturell aktivitet. Det skulle være innlysende at en slik målsetting vanskelig kan la seg realisere gjennom "Objekts-modellen”. [-]

Prosess-modellen [-] er et forsøk på å illustrere at dokumentasjon, forskning og annet kulturelt arbeid kan foregå i et samspill eller i en samhandling mellom institusjon og samfunn ved at arbeidet inngår i en prosess der både samfunn og institusjon opererer sammen. [-]

En slik arbeidsform satt i system vil kunne gi både et kvantitativt og kvalitativt rikere "produkt" pluss flere positive "biprodukter", der selve prosessen representerer både et mål og et middel. ${ }^{40}$

Fjellheim viser også hvordan kulturminnevernarbeidet på 1980-tallet ble en læreprosess både for registratorene og de samiske lokalsamfunnene. For 7 av 23 registratorer ble registreringarbeidet innfallsporten til å starte studier på høgskole/universitetsnivå i kulturminnevern-relaterte fag. Det som provoserte fram Fjellheims forskningsprosjekt, var "konsulentstriden" med Tromsø Museum i 1989. Fortsatt ble då det norske storsamfunnets akademiske formalisme-krav satt foran den samiske miljøets krav om at samene måtte få ansette samer til sine kulturvernoppgaver.

\section{KONKLUSIONER \\ OG PERSPEKTIVER VIDERE}

Folkemuseumsidéen førte til vern og presentasjon av bondekulturen i det norske museumsbildet. Økomuseumsbegrepet har så tydeliggjort en alternativ folkelig museumsmodell for nye grupper i Norge som ønsket å ivareta og bevisstgjøre seg sin kultur: - kystbefolkningen, industriarbeiderne, og samiske lokalsamfunn og folkegrupper.

Økomuseet har representert et kritisk utgangspunkt og et helhetssyn. Dette har gjort det mulig å knytte museumsaktiviteter til aktuelle nåtids- og framtidspørsmål, uten at en totalt måtte avvise museumsinstitusjonen som medium og arbeidsform. Dette har vært viktig, ikke minst fordi museene har hatt faste offentlige tilskuddsordninger.

Gjennom økomuseene er det reist helt nye utfordringer til arbeidsmåter, og et kritisk lys på rollen til den akademiske museumsprofesjonelle. Nye metoder er utviklet, og alternative rollemønstre utprøvd. "Gjenstandsmuseene" er nå bare en museumsform, "menneskemuseene" er like legitime.

Økomuseumsbegrepet samler en kritikk mot fagdisiplinenes oppsplitting av virkeligheten. I økomuseene bygger en på et vitenskapssyn som integrerer kultur-, samfunnsog naturfag. En legger et historiesyn til grunn som ikke primært verdsetter det antikvariske, altså fortidsverdiene, - men nåtidige og kritiske elementer ved historien. En vektlegger en pedagogikk og et syn på estetikk i omgivelsene som skal bevisstgjøre enkeltmennesket, $\mathrm{i}$ forhold til sin rolle som innbygger $\mathrm{i}$ et nærmiljø og lokalsamfunn.

Forståelsen av museenes rolle og situasjon i Norge idag er sterkt preget av mangel på forskning om museene. Dette gjør at vi i liten grad har innsikt og djupere forståelse av museenes etablering, virksomhet, endring og betydning. Det finnes heller ingen museumsutdanning pa høyere nivå. Mange i museene prøver seg fram i sitt arbeid med basis i et svakt teoretisk grunnlag. Vanskeligheter med å definere oppgaver og ikke minst å etablere økonomisk grunnlag for arbeidet, gjør det lett 
48 å bli fanget i de feller som kortsiktige økonomiske vinninger kan gi. Her ser vi nå et stort press fra turistnæringen, som gjerne vil høste kjappe fortjenester. De legger lett opp til situasjoner museene kanskje i liten grad forstår og kjenner de langsiktige effektene av. Erfaringene fra den såkalte "heritage-industrien" i England på 1980-tallet kan tjene som en klar advarsel. ${ }^{41}$

Fire utfordringer: Hvilken retning museumsutviklingen vil ta videre er et åpent spørsmål. I avslutningen av artikkelen presenterer vi likevel 4 teser som deler av et grunnlag for en videre refleksjon omkring økomuseet som en samfunnsrettet museumsform:

\section{1.}

Arne Martin Klausen forsøker i 1989 å gi svar på spørsmålet om museene kan være samfunnskritikere. Han finner museene stort sett som "templer for ting", og der vil deres budskap og funksjon være "å vise, vedlikeholde og formidle kulturelt fellesskap og det som måtte finnes av kulturelt minste felles multiplum". Museumsbesøket blir et rituelt tempelbesøk, en funksjon mennesket alltid har hatt behov for å dekke.

Likevel finner Klausen to museumstyper han mener kan fungere samfunnskritisk, etnografiske museer og økomuseer:

...om museene fungerer kritisk, er det i den grad de fortsatt fungerer som et massemedium og formidler kritiske budskap fra ulike fagmiljøer med alternative kultur- og samfunnskritiske forståelsesmåter. ${ }^{42}$

-Tese 1: En utfordring for økomuseene vil derfor vare à utvikle sitt kritiske potensiale, kanskje nettopp ved a utvikle og presentere alternative framtidsmodeller og konsekvenser av andre kulturelle prioriteringer enn de som gjøres idag, - vi kan kalle det synlige utopier.
2.

Økomuseene befinner seg i samfunn knyttet til avgrensede befolkninger, - enten det er rent geografiske avgrensninger, sosiale eller etniske avgrensninger. I alle slike samfunn dannes det ledere som i kraft av naturlig autoritet, ferdigheter eller av andre grunner får tillitt fra hele eller store deler av den befolkning de representerer. Samtidig er disse ledere opinionsdannere overfor gruppen. For den museumsprofesjonelle i økomuseet vil det ved siden av å ha almenn museologisk og museografisk innsikt, være viktig nettopp å kunne etablere en fruktbar toveis-kommunikasjon med disse ledere.

- Tese 2: En utfordring for økomuseene er å utvikle nye typer museumsprofesjonalitet, der toveiskommunikasjon etableres som en permanent prosess overfor museets målgruppe(r).

\section{3.}

Tradisjonelle museer lider sterkt av sin inadvendthet og mangel av evne til å samarbeide både med hverandre, men også med andre institusjoner og organisasjoner i samfunnet. Samtidig drukner disse museene i materiale med udefinert betydning. Eller for å si det med Neil Postman: "Ingenting er så tåpelig som en sannhet på feil tid." Han vil ikke ha museer som lovpriser idéer det ikke er bruk for, og han setter sitt poeng på spissen:

Året er 1933, og du har fătt frie hender til å bygge opp et museum i Berlin, og det har ikke gått opp for deg at du kan bli skutt eller straffet på annen måte for noe du kan komme til å gjøre. Hva slags museum vil du skape? Hvilke idéer vil du forfekte? Hvilken del av fortid, nåtid og tenkt fremtid vil du fremheve, og hvilken del vil du overse? Kort sagt, hva vil du vise dine tyske besøkende? ${ }^{43}$ 
-Tese 3: En utfordring for økomuseene er à etablere et etisk grunnlag for museet som er $i$ tråd med det virkelig nødvendige i var tidsalder. En del av en slik etikk vil vare à ta standpunkt for økofilosofenes dypøkologiske bevegelse i kontrast til den grunne økologiske bevegelse. A utdype et etisk fundament vil ogsa gjøre det lettere à velge nødvendige alliansepartnere.

\section{4.}

Den tid vi lever i er på mange måter uttrykk for modernitetens krise. Den bastante utviklingsoptimisme og framskrittstro som dominerte vår kulturform fram til omkr. 1970, har idag overlevd bare i spesielle industri-teknokratiske og andre fanatiske, skjermede miljøer. Samtidig opplever vi at mange vil flykte til fortida, - til en nostalgi, der en ønsker å gjemme seg bort istedet for å ta del i vår generasjons utfordringer. ${ }^{44}$ Alle tings tingliggjøring, - at all kultur skal gjøres til varer, innebærer også farer for at en lar seg presse til spekulativ kommersialisering, unyttiggjøring og ufarliggjøring.

-Tese 4: En utfordring for økomuseene er à skape berettigelse for sin eksistens og virksomhet ut fra et idé-og verdimessig grunnlag som ikke er knyttet til en bevisstlos og holdningsløs kommersiell markedstenkning.

Dette er 4 utfordringer til økomuseer for årene framover. Gjennom å formulere et slikt knippe utfordringer (egentlig ville det vært mulig å sette opp et større antall), understreker vi museumsinstitusjonens nåtidige karakter. Eller for å sette det på spissen slik historikeren og museumsmannen Anders Ole Hauglid gjør: "Historien er våre handlinger - nå!”45

Mange som ser økomuseene utenfra, kritiserer økomuseumsidéen for å være utopisk.
De har antakelig rett i det. Alle utfordringene her vil kanskje ikke være lette å løse. Men uten mål å rette seg mot, vil menneskene ikke nå videre. Det kan ikke være tvil om at økomuseene nå på 1990-tallet kan koble sammen museumsinstitusjonen og et økologisk helhetsperspektiv på en helt annen måte enn for 20 år siden. De franske økomuseene er derfor idag en museumshistorisk referanse, i likhet med det enkelte øvrige lands egen museumstradisjon. ldag er det økologiske helhetsperspektivet dypere festet i den generelle mentalitet, gir et annet utgangspunkt også for museene, for den museumsprofesjonelles rolle og for museenes forhold til samfunnet. Filosofinestoren Arne Næss får siste ord:

Idéhistorien viser at bak all nyskaping i historien, bak alle nye tidsepoker og revolusjoner har det alltid stått en filosofi. Dette er ikke bare en påstand, det er forhold som er undersøkt og påvist. Det som vi nå er på vei til å skape er en ny filosofi, en bevisstgjøring av idéene, og denne er nødvendig som en platttform for å fullføre de konkrete oppgaver. Gjennom samtaler, litteratur og massemedia synker idéene langsomt ned i oss alle. Det er en mental omstillingsprosess som foregår og det er nødvendig at alle er med på den for at vi skal lykkes i å beherske situasjonen. ${ }^{46}$

\section{Noter}

- Texten återgiven efter HEIMEN. Lokalhistorisk Tidsskrift $1 / 93$.

1. Artikkelen bygger delvis på foredrag på den nordiske konferansen om lokalkultur i Eidfjord 4/9 1992, og delvis på senere arbeid knyttet til artikkelforfatterens NAVF-prosjekt: "Museum, kulturarv og lokalsamfunn". Viktig bakgrunn finnes i John Aage Gjestrum og Marc Maure (red.), Økomuseumsboka - identitet, økologi, deltakelse. Norsk ICOM, Tromsø 1988, og 
temanummeret: "Images of the Ecomuseum", Museum, Unesco Paris 1985. nr. 148 vol. 37, nr.4. Om artikkelforfatterens egne erfaringer med økomuseum vises til: Dagfinn Slettan: Kulturvernet møter 90-åra. Toten Museum, økomuseum og lokalhistorisk senter. Heimen 2/ 1990, s. 66-78.

2. Kenneth Hudson: Letter from Gratangsbotn. I Museums Journal. London, april 1991, s. 20. (alle sitater på fremmedspråk oversatt av forf.) Kenneth Hudson er kjent som forfatter av flere viktige bøker om internasjonale museumspørsmål, bl.a. Museums for the 1980s (1977) og Museums of Influence (1987). Han er siden 1977 direktør for "The European Museum of the Year Award", som deles ut av Europarådet.

3. Kenneth Hudson: The dream and the reality. Museums Journal, London april1992, s. 27-31, sit. s. 31 .

4. Statens museumsråd utga i 1990 Adresseliste for norske museer og samlinger. Denne viste et totaltall på 547 museumstiltak. I 1992 utga Norsk Museumsutvikling Adressebok for norske museer og samlinger 1992/93, med et totaltall på 777 museumstiltak.

5. Gabriel Gustafson: Landsmuseer og Bygdemuseer. Verdens Gang 16/12 1901.

6. Anne-Lise Landmark: Adressebok for norske museer og samlinger 1992/93. Norsk Museumsutvikling. Oslo 1992.

7. Brit Berggreen: Da kulturen kom til Norge. Oslo 1989.

8. Om de første folkemuseene se Tonte Hegard: Romantikk og fortidsvern, historien om de første friluftsmuseene i Norge. Oslo 1984. Se også Reidar Kjellberg : Et halvt århundre. Norsk Folkemuseum 1894-1944, Oslo 1945, videre Tord Buggeland og Jakob Agotnes: Maihaugen, De Sandvigske Samlinger 100 år, Oslo 1987 og Arne Biörnstad (red.): Skansen under hundra år. Höganäs 1991 .
9. Kaj Uldall: Open Air Museums. Museum 10. Paris 1957, s. 74. Se også Elisabeth M. Adler: The Folk Museum, i Michael Steven Shapiro (red.): The Museum. A Reference Guide. New York og London 1990. s. 115-139.

10. Tallene bygger på Innstilling om de halvoffentlige museers virksomhet og drift. Museumskomitéen 1967. Bergen 1970. s. 9. Tolkningen støtter seg bl.a. til Hakon Shetelig: Norske museers historie. Oslo 1944.

11. John Aage Gjestrum: Museer for 2000-tallet. i Dokumentasjon av samtid og nær fortid. Rapport fra NKKM's fagseminar IV. Lillehammer 1986. s. 9-21.

12. Innstilling om de halvoffentlige museers virksomhet og drift. Fra Museumskomitéen 1967. Bergen 1970.

13. Christian Norberg-Schulz: Mellom jord og himmel. Oslo 1992. s. 14.

14. Ibid s. 25-26.

15. Referert her fra Johan Asplund: Tid, rum, individ och kollektiv. Stockholm 1983, s.169-170.

16. Kevin Walsh: The Representation of the Past. Museums and heritage in the postmodern world. London and New York 1992, s.148-159.

17. Harald Winge ved Norsk Lokalhistorisk Institutt opplyser (tlf. mai 1992) at det i tidsrommet 1969-1990 i Norge ble utgitt 537 bind gards- og slektshistoriske bygdebøker, og 351 bind generell bygdehistorie. I 1991 ble det utgitt 20 bind gards- og slektshistorie og 18 bind generell bygdehistorie. Før 1969 er det utgitt mer enn 200 bind gards- og slektshistorie. Se ogsa: John Aage Gjestrum, Gards- og slektshistoriske bygdebøker, Lena 1984.

18. Steinar Imsen i anmeldelse av Trygve Viks gardshistorie for Ås. I Heimen 1975, s. 597.

19. Arne Martin Klausen: Kultur- mønster og kaos. Oslo 1992.

20. Om Økopolitikk og økofilosofi, se. f.eks.: Sigmund Kvaløy Sætereng, Økokrisefilosofi - glimt 
fra det norske økofilosofiske forsøket. I Svein Gjerdaker, Lars Gule og Bernt Hagtvet (red.), Den uoverstigelige grense. Tanke og handling i miljøkampen, Oslo 1991, s. 102-116. Arne Næss: Den dypøkologiske bevegelse: aktivisme ut fra helhetssyn. I: Gjerdaker/Gule/Hagtvet (red. 1991) op.cit. s. 21-43. Ottar Brox, Hva skjer i Nord-Norge, Oslo 1966. Hartvig Sætra: Den økopolitiske sosialismen. Oslo 1973. Bokas første utgave kom i 1971 under tittelen "Populismen i norsk sosialisme". I Norge ble populismebegrepet fra slutten av 1960-tallet brukt om et felles grunnlag for en folkelig økopolitisk bevegelse som fanget langt videre enn de rene sosialistiske politiske grupperinger. Et viktig miljø var PAG - de populistiske arbeidsgrupper som hadde utspring i studentmiljøet ved Universitetet i Bergen. Viktige bøker er: Populistiske Arbeidsgrupper i Bergen. Norsk populisme. Oslo 1972. Sigmund Borgan m.fl., Økopolitikk og populisme. Oslo 1979. Hartvik Sætra har i ei ny bok: Jamvektssamfunnet - er ikkje noko urteteselskap, Oslo 1990, plassert 1970-tallsidéene inn i 1990tallet.

21. Georges Henri Rivière: The ecomuseum - an evolutive definition. Museum Unesco Paris 1985, op.cit. s. 182-3. Dette er den tredje og siste versjon av Rivières tekst, avsluttet i januar 1980. Georges Henri Rivière (1897-1985) stod fra 1920-tallet av sentralt i å etablere en interesse for fransk folkekultur. Han virket internasjonal som ICOM:s første direktør 1947-1964. I en alder av 72 år startet han museologiundervisning ved Sorbonne.

22. Hugues de Varine: Rethinking the museum concept, i Gjestrum/Maure (red. 1988) op.cit. s. $33-40$.

23. Se Walsh (1992) op.cit. s. 160-175. og Hugues de Varine: Om økomuseet, i Gjestrum/Maure (red.1988) op.cit. s. 104-122.

24. Se f.eks. Andrea Hauenschild: Neue Museologie.
Anspruch und Wirklichkeit anhand vergleichen-
Bremen 1988. Nancy J. Fuller: The Museum as a Vehicle for Community Empowerment: The AkChin Indian Community Ecomuseum Project. I Karp, Kreamer og Lavine (red.): Museums and Communities. Washington 1992, s. 327-365. I mai 1992 ble det arrangert et nordisk Økomuseumsseminar i Danmark. Rapport er under utgivelse ved Samsø Økomuseum i Danmark.

25. Øystein Frøiland: Økomuseet - tverrvitenskap i praksis. Museumsnytt 2/1975, s. 98. Se også Synnøve Vinsrygg: Det integrerte museum. Museumsnytt 4/1980, s. 187-193.

26. Hugues de Varine, The Museum in the fourth Dimension, Umeå 1976. Trykt i dansk oversettelse i Dansk tidsskrift for museumsformidling 4 (1979), s. 61-65.

27. Marc Maure, Kultur og nærmiljø - nye veier i museumsverdenen. Museumsnytt 4/1977, s. $147-151$.

28. Pierre Mayrand, The new museology proclaimed. Museum, Unesco Paris 1985, op.cit. s. 200-201.

29. Steinar Wikan: Sør-Varanger, i Gjestrum/Maure (red. 1988) op.cit. s. 163-166.

30. Sitert fra notatet "Invitasjon til medlemskap i Den norske gruppe av Økomuseer." Utarbeidet av Anders Ole Hauglid og John Aage Gjestrum. Storslett/Bøverbru 3. apriI1984. Se ogsa: John Aage Gjestrum, Seminaret: Økologi og identitet. Økomuseumstanken har slatt rot i Norge. Museumsnytt 2/1984, s. 9-14.

31. De 12 museene var: Rjukan (Telemark), Røros (Sør-Trøndelag), Klevfos industrimuseum, Trysil/ Engerdal og Nord-Østerdal (Hedmark), Toten (Oppland), Florø/Kystmuseet (Sogn og Fjordane), Woxengs samlinger (Nord- Trøndelag), Vefsn (Nordland), Senja og Nord-Troms (Troms), Sør-Varanger (Finmark). Gjennom de tre første årene samarbeidet museene nært, bl.a. ved gjennomføring av 6 større fagseminarer. I 
52 årene etterpå har kontakten foregått mindre organisert, men på basis av det oppbygde nettverket. Hovedvekten har vært lagt på å opprettholde kontakter med utviklingen i det internasjonale museumsmiljøet.

32. Det var Toten, som faktisk hadde landets første "distriktskonservatorstilling" fra 1953. Om ideologien knyttet til det lokale museumsarbeid på Toten, se Johannes Sivesind: Visjon og virke. (også TOTN Årbok) Lena 1991.

33. Se Einar Niemi: Norsk lokalhistorie på 1970- og 80-tallet - paradigmeskifte eller kontinuitet? Heimen 4/1989, s. 195-204. Om nord-norsk lokalhistorie skriver Niemi bl.a. (s. 200) om "den særlig sterke koblingen på 70- og 80-tallet mellom historie og politikk - politikk i videste forstand av begrepet - en kobling som i enkelte sammenhenger har antatt en nesten eksistensiell dimensjon. Dette er forøvrig et forhold som vekker assosiasjoner til den lignende kobling på riksplan mot slutten av 1800-tallet."

34. Else Espeland, Kare Sveen, Britta Tønseth (red.): Museer i Norge. Museumsnytt 1988 (Engelsk utgave ajourført og utgitt 1989).

35. John Aage Gjestrum og Marc Maure: Arbeidarkulturen på museum. Syn og Segn 2/1989, s. $157-164$.

36. Mari Teigmo Eira: Sami museum work and the Sami culture, i Traditions et perspectives nordiques. MINOM/ICOM 3. atelier intemational de nouvelle muséologie, Toten 1986, s. 38.

37. Sigbjørn Dunfjeld: I grenseland museum/kultursenter. I Museumsnytt 4/1988, s. 43-45.

38. Gjengitt fra Reidar Erke: Samisk museumsstruktur. I: Museumsnytt temanummer om Samiske museer - Samisk kulturvern 4/1988. s. 10.

39. Sitert etter Sverre Fjellheim: Saemien Sijte Museum, kultursentrum og samlingspunkt. Dugnad 11/1987, s. 33.

40. Sverre FjeIlheim: Kulturell kompetanse og områdetilhørighet. Metoder, prinsipper og prosesser i samisk kulturminnevernarbeid. Saemien Sijte, Snåsa 1991.

41. Se Robert Hewison: The Heritage Industry, Britain in a Climate of Decline. London 1987. Robert Hewison: The Heritage Industry revisited. Museums Journal, London april 1991, s. 23-26, og Walsh (1992) op.cit. s. 116-147.

42. Arne Martin Klausen, Museene som samfunnskritikere. I Museene i samfunnet. NKKM's fagseminar 1989, rapport s. 95-102.

43. Neil Postman: En utvidelse av museumsbegrepet: "Hva vil det si å være menneske?", foredrag på ICOM's generalkonferanse, Haag 1989. Gjengitt noe forkortet i norsk oversettelse i Museumsnytt 4/1989 s. 26-28, sitat s. 26.

44. Se David Lowenthal: The Past is a Foreign Country. Cambridge 1985, s. 3-35, og Anders Johansen: Ting, tid, identitet. Syn og Segn 3/ 1989, s. 226-240.

45. Anders Ole Hauglid: Nord-Troms Museum. Økomuseum i et fleretnisk område. Museumsnytt 3/4 1985, s. 73.

46. Arne Næss: Økologi, samfunn og livsstil. Oslo 1976, s. 114-115. 


\title{
EIT MUSEOLOGISK PERSPEKTIV
}

\author{
John Aage Gjestrum
}

Innanfor det som er mogleg på nokre ganske få sider, skal eg dra opp eit perspektiv på disiplinen museologi, eit fag som ennå ikkje har fätt fotfeste i norsk universitets- eller museumsroyndom. Dette trass $i$ at museumsorganisasjonar, statlege organ og alle universiteta $i$ landet gjennom dei tre siste tiåra har hatt store utreiingsarbeid på området, og gjort forsøk på å få aktivitetar igang. Eit spørsmål som kan reissast, er derfor kvifor dei faktiske resultata er så magre når kravet om utdanningstilbod på feltet har vore eintydig?

Internasjonalt representerer feltet eit sterkt veksande fagområde, og dei siste 6-7 åra har på mange måtar vist ei nyorientering i forskinga med ei aukande mengd av publisert arbeid. Samstundes synest museer og kulturarv å bli stadig viktigare som kulturelle markørar i vår tid. Ei utvida forståing av museumsfenomenet innebær og viktig auke i vår kunnskap om det moderne menneske og kultur i det heile.

I Norge har det gjennom dei siste 30 åra frå mange hald vore uttrykt ønske og gjort faktiske forsøk på å få etablert museologi som fagdisiplin. I ettertid kan resultata frå desse 30 åra oppsummerast som nærast eintydig negative.

På 1960-talet vart det tatt initiativ i museumsorganisasjonane. Innstillinga Et norsk museumsseminar låg føre i 1965. På 1970-talet kom universiteta til: I 1972 vart det reist forslag om å opprette museologi som fag i Bergen (Kloster 1972), - i 1973 vart det arrangert fagkurs i museologi ved Vitskapsmu- seet og Universitetet i Trondheim. Men etter tre år stoppa det opp. Dei regionale høgskulane i Stavanger og Bø i Telemark la frà siste halvdel på 1970-talet inn visse museumsretta deler i kulturarbeidarutdanninga. I 1985-86 var det framme forslag om å etablere grunnfag i museumskunnskap ved Universitetet i Tromsø. Frå 1987 blir det kvart år gitt tilbod om ei halvårseining i museumskunnskap ved Universitetet i Oslo.

Museumsorganisasjonane og etter kvart Statens Museumsråd (i funksjon 1979-1991) arbeidde med museumsutdanning gjennom nye utgreiingar, komitear og konferansar gjennom heile 1970- og 80-talet (Gjestrum 1988).

Dette står i skarp kontrast til det som skjedde da museumsforbundet vart oppretta i 1918. Da tok ein opp "Kravet til norske museumsmænds faglige utdannelse" som eit av fire hovudoppgåver i arbeidsprogrammet. Museumsforbundet hadde forslaget klart til løysing, - det var å få til obligatorisk undervising i norsk kunsthistorie og arkeologi ved 
54 universitetet (den gong berre universitet i Kristiania) "saaledes at der for dem som vil gaa museumsveien maa bli adgang til å ta examen i faget ved Universitetet" (Gjestrum 1993). Frå kravet vart reist og til det heile var i orden gjekk det tre år. Frå 1921 var det høve til å ta magistergraden i arkeologi og kunsthistorie. Seinare kom etnologi til i 1941.

På 1960-talet var det imedlertid klart at ein i museumsarbeid trong noko meir enn spesialiserte gjenstandsfag. Kloster-komitéen som i 1972 la fram forslag om etablering av museologi ved Universitetet i Bergen peika på at det er "meget betenkelig at det ved ansettelse i museumsstillinger ikke stilles formelle krav til innsikt i museumsarbeidets teoretiske og praktiske grunnlag" (s. 20).

Kloster-komitéen la vekt på studiar av kva som skjedde i flere andre land, både i forståinga av kva museologi kunne vere og korleis musea vart aktiviserte.

Museene spiller en rolle i samfunnet, de integreres i undervisning og i forskning, de har sosiale oppgaver og de nyttes som medier. Deres register er blitt større og dette har igjen ført til at deres prinsipper og teori, museologien, har etablert seg som en nødvendighet $\mathrm{i}$ det museale arbeidet.

Museologien er den teoretiske, filosofiske bakgrunn for museumsarbeidet. Den låner elementer fra en rekke eksisterende fag og anvender disse innen museernes spesielle situasjon.

Museet er den integrerende part i faget museologi. Det består av mange "museologiske fag" som hver har sin metodikk korresponderende til den metodikk faget ville hatt som selvstendig vitenskapsgren (s. 21).

Innstillinga frå Kloster-komitéen føyer seg inn i den lange rekka med dokument som ikkje gav resultat. Når ein i ettertid ser attende på desse 30 åra, er det verkeleg skremmande at så mange framståande fagfolk innan muse- um, universitet og kulturområda har lagt fram så mykje vilje og meiningar og oppnådd så lite. Utan tvil ligg det ei interessant og utfordrande oppgåve i å granske korleis dette i det heile har vore mogleg.

Sidan noko slikt forskingsprosjekt ennå ikkje er gjort, kan eg heller ikkje gje fullgode og uttømmande svar på kvifor det har gått så gale. Noko vil eg likevel trekke fram som moment i moglege hypotesar:

- Ein har i alle desse åra ikkje greidd å skilje kva som skulle vere del i ei akademisk basisutdanning for museumsfeltet, og kva som skulle vere museas ansvat for fagleg oppdatering av sine eigne tilsette.

- Samstundes som ein har argumentert for musea som vitskaplege institusjonar knytta til dei ulike gjenstandsbaserte kultur-, kunst- og naturhistoriske vitskapane, har det heilt mangla vilje til å sjå vitskapleg (må forståast som = kritisk/analytisk) på museet som kulturelt/sosialt fenomen.

- Når det vitskaplege i musea så åleine er knytt til dei ulike gjenstandsvitskapane, vil det ved dei større musea - t.d. universitetsmusea - vere større integrering mellom arbeidet til den einskilde vitenskaplege medarbeider ved museet og fagfeller utanfor museet innan same fagområde, enn det vil vere mellom forskarar innanfor same museumsinstitusjon. Museet har ikkje noka eigen vitskapleg plattform å legge til grunn for tverrfagleg integrering.

- Dei viktige og gjennomgripande omskifta innan vitskapsteoretiske paradigme som har skjedd dei siste vel 30 åra har berre i liten grad nådd musea. Gamle positivistiske tenkjemåtar om objektiv, akkumulerande kunnskapsproduksjon lever trygt vidare.

- Museologi som eit vitskapleg og kritisk perspektiv på museumsfenomenet - påa alt frå 
korleis kultur- og naturarven blir konstruert ved urvalsprosessane - musealisering-, til kva bodskap og ideologi ein lar samlingane formidle, - fins altså knapt i Norge i dag. Derfor finst det ikkje verken nokon konsensus mellom fagfolk, eller nokon reell diskurs omkring kva ein er fagleg sams om eller ikkje sams om.

- Når ein undrast over kvifor situasjonen viser seg å bli fastlåst over så lang tid, må dette og ha noko å gjere med korleis vitskapssamfunnet fungerer. Utanfor musea, som ved universiteta, er ein i stand til å gjere store omskifte på relativt kort tid, t.d. ved val av fagprofil gjennom tilsettingar i vitskaplege stillingar, undervisingsformer, utforming av fagplanar og val av pensumslitteratur. Ein har heile tida brukarane - det vil seie studentane - i institusjonen som ei aktiv, kritisk og påverkande - til og med inspirerande - kraft.

I musea kan fagleg profilering og linjeskifte vere mykje tyngre å påverke. Tradisjonen er ikkje slik at skifte i fagstillingar inneber at dei som blir tilsette ser det som si oppgåve å gjennomføre endringer. Samlingane som alt er der, får legge premissane. Større endringar i utstillingar kan ligge langt utanfor det økonomisk realiserbare. Frå brukarane - publikum, som gjerne er ganske anonyme - kjem det oftast høflege, men ikkje særleg konstruktive tilbakemeldingar.

\section{IKKJE SPØRSMÅL, MEN FERDIGE SVAR?}

I 1985-86 la ein ved Universitetet i Tromsø fram ein plan som omfatta grunnfag i "museumskunnskap (museologi)". Studieplanskissa er eit typisk eksempel på ein "teknisk" og forvaltingsorientert tenkjemåte omkring museumsfeltet. Studiet var bygd opp i fem deler:
1. Ideologi, organisasjon og administrasjon

2. Innsamling, dokumentasjon og forskning

3. Oppbevaring, konservering og restaurering av museumsmateriale

4. Formidling/udadrettet virksomhet

5. Forvaltningsvirksomhet

(Kunst- og kulturfag ved Universitetet i Tromsø. 1986)

Det kanskje mest karakteristiske ved dette opplegget er oppfatninga av museumskunnskap som eit ferdig utvikla kunnskapsområde som så berre skal innlærast av studentane. Museumskunnskap slik ein legg det fram her inneheld ikkje åpne spørsmål, men ferdige svar. Det er ei reiskapsfag som skal gjere studenten eigna til å nytte sit "egentlige fag" (Hohler 1993) - kunsthistorie, arkeologi, etnologi, zoologi osb. i museet, - dei faga musea etter mange si meining er til for.

Halvårseininga i museumskunnskap som omlag 12 studentar får høve til å ta ein gong i året ved Universitetet i Oslo sedan 1987 er bygd opp på same måten. Museologisk teori som kritisk vitskap har liten plass i desse samanhengane.

\section{MUseologien FÅR EIT INNHALD}

Sjølv om vi altså har peika på ei lang historie med lite resultat, er det slik at dette òg gir føremoner idag.

Hadde det vore satsa mykje ressursar på undervisning i museologi på 1970-talet eller tidlig på 1980-talet, er det ikkje sikkert ein hadde hatt så mykje fagleg spennande innhald å legge inn.

I dei nordiske landa har enno ingen doktorert i museologi. I England skjedde det første gong i 1983 (Teather). Arbeidet med museologi i ICOM tog først fart på 1980-talet. Den internasjonale komitéen for museologi 
56 ICOFOM, tok frå 1983 til å publisere Icofom Study Series, som til nå er utgitt i vel 20 band.

Frå slutten av 1980-talet og først på 1990talet er det òg blitt ein ganske annleis storleik på det internasjonale fagmiljøet - noko som igjen kan avlesast gjennom talet på nye bøker og andre publikasjonar innan emnet.

Frå 1960-talet hugsar vi Germain Bazins bok "The Museum Age" (1967), frå 1970-talet nokre fleire: Alma S. Wittlin: "Museums: In Search of a Usable Future" (1970) og Kenneth Hudsons to bøker: "A Social History of Museums"(1975) og "Museums for the 1980s" (1977).

Litteraturen som kjem frå omkring midten av 1980-talet og framover avspeglar først og fremst ei langt breiare akademisk interesse for museumsfeltet, og nye vitskapsteoretiske perspektiv kjem inn. $\AA$ fange inn omfanget av denne litteraturen vil føre for langt her. Noko kan likevel trekkast fram:

Viktige teoretiske bidrag finn vi t.d. i Hobsbawms "The Invention of Tradition"(1983), i Hewison (1987) som formar omgrepet heritage industry, og i Pomian (1990) si påpeiking av at museas viktigaste funksjon er $a ̊ g j e r e ~ d e t$ usynlige synleg.

Susan Pearce leiar avdelinga Department of Museum Studies ved Universitetet i Leicester, England. Ei av dei mest interessante karakteristika ved musea ho trakk fram i den viktige boka "Museums, Objects and Collections" (1992) var at store delar av museumssamlingane var etablert som samlingar alt før gjenstandane kom til museum.

Desse spørsmåla er viktige når ein skal skjøne kva musea og musealisering som fenomen er for noko.

\section{Kulturarv， naturarv， Miljøarv}

Per-Uno Ågren (1993) bruker nemninga miljöarven om den materielle kulturarven. Kulturarven inkluderer og naturarven ettersom seleksjon, klassifikasjon og forståing av naturen og skjer i kulturelle prosessar og institusjonar, mellom anna i museum.

Svante Beckman (1993) har vist korleis kulturarven kan forståast som ein infrastruktur i samfunnet, på line med andre infrastrukturar. Tilfeldig historisitet og konstruerte myter fungerer gjerne like godt som autentiske kulturarvelement. Ei spenning finst òg mellom ein holistisk kulturarv - slik som t.d. ulike sosiale og etniske grupper vil sjå på sin kulturarv - og på ein partikularisert kulturarv, - slik den finst i museumssamlinger og ofte blir forstått av profesjonelle aktørar i kulturvernområdet.

Einskilde kulturarvelement frå denne partikulariserte kulturarven vil så og kunne nyttest som sosiale markørar og til nostalgiproduksjon. Geir Vestheim (1994) viser korleis teoriane til den franske kultursosiologen Pierre Bourdieu om sosiale felt er fruktbare når ein analyserer museas funksjon.

Den kanadiske museumsmannen Duncan F. Cameron (1992) seier at skal vi forstå museumsinstitusjonane må vi forstå korleis dei har starta.

Too often we believe we know the origins of our institutions when what we have come to know are the myths and legends of convenience that masquerade as hallowed traditions.

Ut frå teoriane til Pearce og Cameron skal ein ikkje granske museas historie særleg lenge før det vert ganske klart at det ikkje er gjenstandsvitskapane som har skapt musea. I staden er det kan hende omvendt? 
Norske MUSEUM

\section{HAR OG EI HISTORIE}

Eit museumshistorisk riss viser at dei nåverande museumssamlingane i Norden vart etablert som kongelige samlinger på 1600-tallet; - for å kaste glans over kongehuset og gje det tilgang til datidas kunnskap utfrå gjeldande paradigmer. For Norge innebar dette at museumsaktiviteten skjedde utafor grensene, ved det danske kongehuset, hovudsakleg i København, der det kongelege kunstkabinettet frå ikring 1650 hadde ei fast organisering.

Opplysingstida og dei nye moderne perspektiva på vitskap og samfunn som følgde revolusjonstida frå slutten av 1700-tallet gjorde slutt på mykje av kongemaktas dominans og dermed også meininga med dei kongelege samlingane. Men gjenstandssamlingane levde vidare. I København fekk ein Nationalmuseet (namnet kom i 1855), grunnlagt i 1807 med ei lita oldsakssamling. Christian Jürgensen Thomsen (1788-1865) tok over leiinga frå 1817 og vart ein leiiande museumsmand i si tid for heile Norden.

Brotet mellom Danmark og Norge i 1814 kutta Norge av frå representasjonen av Norges historie som var bygd opp i Danmark gjennom 200 år.

Den nye unionsparten etter 1814, Sverige med Carl Johan i spissen, tok ikkje på seg oppgåva med ei kulturell integrering av Norge på samme måte som danskane hadde gjort. Dessutan innebar grunnlova frå 1814 som nordmennene hade fătt igjennom, føresetnader om sjølvstende og suverenitet gjennom demokratiske institusjonar på ein måte som hittil ikkje var kjend i Norden.

Nå kjem eg til eit viktig poeng i den historiske utgreiinga: Det er i spenninga som oppstod etter etableringa av grunnlova og dei fyrste 10 krevande åra i unionstida med Sverige, at vi i Bergen fekk Norges fyrste eigenlege museum, Bergens Museum, som då vart etablert nettopp av ein av 1814-heltane, W.C. Christie.

Christie stod på sjølstendelina i 1814, men ikkje sterkare enn at han kunne ta del i etableringa av dei pragmatiske løysingane som måtte til hausten 1814 for å få til ei ordning med Sverige og Carl Johan. Samstundes hadde han i tida etterpå vore aktiv i å sikre grunnloven i maktkampen som gjekk føre seg mellom det nye norske folkestyret og den store uviljen svenskekongen hadde mot dette. To gonger avslo Christie tilbod frå Carl Johan om å bli statsråd. I kraft av sin kompetanse som jurist var Christie leiar for eit arbeid som gjennom juridiske grep skulle gje ei avklaring av tilhøvet mellom Norge og svenskekongen. Dette lukkast ikkje, og utover på 1820-tallet var det fleire svært spente situasjoner mellom Carl Johan og Norge.

Sjukdom gjorde at Christie i 1824 valde å søkje avskjed som stiftsamtmann. Han var berre midt i 40-åra, og stod nå utan dei pliktane ei sentral embetsstilling innebar. Etter ei lengre kurbadreise og opphald i sentrale tyske byer og København, utforma han framlegget sitt til etablering av Bergens Museum.

Det er viktig å merke seg at dette ikkje skjer som ei terapeutisk hobbyverksemd for eit aktivt samfunnsmenneske som nå var sett ut av spel. Nei, Christies initiativ og oppbygging av Bergens Museum må sjåast som ei strategisk handling sentralt plassert i datidas hovedspørsmål. Med grunnloven i 1814 hadde Eidsvollsrepresentantane greidd å legge eit grunnlag for eit faktisk folkestyre. Like mirakuløst hadde ein dei neste 5-6 åra greidd å stable nasjonaløkonomin på beina. Der dei juridiska grepa ikkje greidde å sikre framtida til den 
58 nye fridomen, kunne altså kultur, historie og vitskap gjere det.

Christie fant det derfor "gavnligt at tænke paa en Forening imellem oplyste, for Videnskaberne og Konsterne i Almindelighed og for Historien i Særdeleshed nidkjære, samt for Norges Ære og Nationalitet omhyggelige Mænd" som skal skaffe fram ei offentleg samling i Bergen:

ei Museum for Oldsager og Konstsager, og et Naturaliekabinet af indenlandske Naturalier...Nytten av en saadan Samling lader sig ikke forud i det Hele beregne; men høist sandsynligt er det, at Samlingen vil kunne tjene til at utbrede Lys i den norske Historie, og at redde fra Undergang Minder om Fortiden; at lære nøiere at kjende en eller anden av de Skatte, som Klipperne, Jorden eller Havet indeslutte, og at give Anledning til, at Landets Indbyggere høste Fordele deraf.

(Frå opprop 1825)

Om planen til Christie var ambisiøs, og realiseringen kan hende vart meir krevande enn han fyrst hadde tenkt, fekk museumslaget stor oppslutning. Allereie i 1831 kunne Bergens Museum kjøpe sin eigen bygning til samlingane. Og i 1840 flytta dei inn i det fyrste museumsbygg nokon gong bygd i Norge.

Og like viktig: Bergens Museum vart snart ein modell for museum i så å seia alle viktige byar i landet: Kristiansand prøvde å etablere museum 1828, men lukkast ikkje. Vidare kom: Arendal 1832, Ålesund 1866, Tromsø 1872, Trondheim 1874, Stavanger 1877 , Skien 1891, Tønsberg 1894 og Kristiansund 1894.

På 50-årsdagen for grunnloven i 1814 vart grunnsteinen for det nåvarande museumsbygget til Bergens Museum lagt ned 17. mai 1864. I hovudstaden Kristiania var det fleire mindre samlinger av oldsaker, mynter og anna. Dei vart etterkvart knytta til universi- tetet som var etablert i 1811. Men det var fyrst i 1828-29 dei vart permanent offentleg tilgjengelege (Universitetets oldsakssamling). Nationalmuseet (frå 1851 med namnet Nasjonalgalleriet) vart åpna på slottet i 1842, men fekk ikkje noko eige hus før mot slutten av hundreåret.

På 1800-talet var museum eit byfenomen, knytta til vide altomfattande samlingar og eit opplyst borgerskap. Friluftsmuseum og oppfatninga av norske museum som knytta til bondekultur og nasjonal byggjeskikk er noko som stort sett høyrer 1900-talet til. Det ligg da og venter mange spennande forskingsoppgåver i museumshistoria frå 1800-talet.

\section{EPILOG}

Kva skjedde så med museet Christie etter 15 år med hardt arbeid greidde å få bygd i 1840, og som var det aller fyrste museum bygd $\mathrm{i}$ Norge? Etter det kom nytt museumsbygg i 1860-åra, var det mellom anna skole, og snart var det gløymt. Eg er faktisk ikkje sikker om nokon eigentleg var klar over kva slags monument dei reiv i Bergen omkr. 1970, da dei satte opp det nye rådhuset. Nabohuset til Christies museum, Manufakturhuset, vart redda frå riving, for det vart vurdert som antikvarisk verdfullt.

Kan det vere mogleg å tenkje seg at museologien kan gjere museumsfolk meir medvitne om at dei sjølve og musea faktisk på same vis som andre fenomen i samfunnet også eksisterer i ein historisk samanheng? At dei på same vis som forgjengarane står $\mathrm{i}$ ein nåtidig og aktuell samfunnssituasjon. Forståinga kvifor musea er blitt til og kva dei har vore, kan òg seie oss idag noko om kva museum kan vere for oss og for vår tid. 
Note

- Texten trycktes ursprungligen i Årbok for Bergens Museum 1995 (1996).

\section{LitTERATURLISTE}

Beckman, Svante (1993): Om kulturarvets väsen och värde. I: J. Anselm (red.) Modernisering och kulturarv. Stockholm/Stehag, s. 61-124.

Brunchorst, J. (1900): Bergens Museum 1825-1900. Bergen.

Cameron, Duncan Ferguson (1992): A Change of Heart. I: Museum, Management and Curatorship 11, s. 375-386.

Gjestrum, John Aage (1988): En norsk museumshøgskole. Utredning for NKKM 1988.

Gjestrum, John Aage (1994): Kommentar til Erla B. Hohler: Hva er Museologi? Myte eller Metode? I: Helliesen, Sidsel og Tønseth, Britta (red.): $M$ for Museum. Rapport fra jubileumsseminar. Oslo 3.6. juni 1993. Oslo, s. 43-49.

Gjestrum, John Aage (1993): "Museumsmænd og deres skidne tøi". Museumsnytt 1993:2, s. 4-15.

Gjestrum, John Aage (1995): Museology and research - in a Norwegian perspective. Nordisk Museologi 1995:2, s. 5-22.

Hewison, Ralph (1987): The Heritage Industry. London.

Hobsbawm, Eric and Ranger, Terence (1983): The Invention of Tradition.

Kloster, Robert (1972, formann): Instilling fra komitéen til utredning av museenes stilling innen universitetsstrukturen. Bergen.

Pearce, Susan M. (1992): Museums, Objects and Collections: A cultural Study. Leicester and London.

Pomian, Krzysztof (1990): Collectors and Curiosities. Cambridge.

Shapiro, Michael Stephen (1990 red.): The Museum: A Reference Guide. New York, London, Westport.
Shetelig, Haakon (1944): Norske museers historie.

Oslo.

Stansfield, Geoffrey og Woodhead, Peter (1994): Key-guide to Information Sources in Museum Studies. London og New York, 2. ed.

Teather, J. Lynne (1983): Museology and its Traditions. The British Experience 1845-1945. Upublisert doktoravhandling, Leicester.

Universitetet i Tromsø (1986): Kunst-og kulturfag ved Universitetet $i$ Tromsø.

Westheim, Geir (1994): Museum i eit tidsskifte. Oslo.

Walsh, Kevin (1992): The representation of the past. Museums and heritage in the postmodern world. London og New York.

Ågren, Per-Uno (1993): Museologi och kulturarv. Nordisk Museologi 1993:1, s. 61-65. 
Nordisk Museologi 200I • I-2, S. 60-70

\title{
UTSTILLING
}

\section{AV LEVENDE MENNESKER}

\section{En historie om samisk kultur og fremmede blikk}

\author{
John Aage Gjestrum
}

I Rørosregionen kjenner vi ei sørsamisk befolkningsgruppe langt bakover i tid. Samene har da også sammen med andre i Rorosregionen deltatt $i$ den lokale museumsvirksomhet, - samene markerte seg her spesielt aktivt i tida fra like for $1950 \mathrm{og}$ framover til ut på 1960-tallet. Min overraskelse var derfor stor då jeg fant Rørossamer som midtpunkt $i$ Londons museumsverden allerede for mer enn 190 år siden - for vi hadde museer $i$ Norge $i$ det hele tatt. Og det var ikke bare deres sarpregede kultur $i$ form av gjenstander og miljø som ble utstilt - nei en hel samefamilie var også satt $p a ̊$ utstilling. Hva var det som skjedde? Nysgjerrigheten bragte meg videre i a studere fenomenet med å sette levende mennesker på utstilling. Artikkelen handler om dette. Den sier også noe om datidas oppfatning av samene.

Temaet utstilling av levende mennesker kan følges langt tilbake, ikke minst møter vi det når erobrere skulle bevise sin erobring med å bringe hjem representanter for nye undersåtter. Fra renessansen av ble også datidas museumsformer, de kongelige kuriositets- og kunstkamre, fylt med gjenstander fra hele den kjente verden. Disse samlingene var uttrykk for datidas kunnskap og rasjonalitet. Men de ble til ikke minst også som uttrykk for herskerens makt og herrevelde.

Godt kjent er historien om de ekspedisjoner kong Christian IV sendte til Grønland 1605-1606, der han tok til fange 5 eskimoer med deres kajakker. I alt 9 eskimoer ble ført levende till København, beskrevet av datidas vitenskapsmenn og vist fram til folks forlystelse. I denne skrekkelige fortellingen vet vi at alle 9 døde nokså snart: Noen, sies det, av hjemlengsel, én da han forsøkte å nå tilbake til Grønland med kajakken sin, én under perlefiske og den siste "af gremmelse".

Forsøket ble senere gjentatt i 1654 da fire grønlendere, en mann og tre kvinner, ble tatt til fange i Godthåb-fjorden. De er i ettertid mest kjent fra maleriet av dem, som etter påskriften er malt i Bergen. På reisa derfra til København döde mannen, mens de tre 
kvinnene ble ført til kong Fredrik III og hans hoff. Tanken var at de så etter litt "opplysning" skulle sendes tilbake til Grønland. Desverre gikk det ikke flere skip til Grønland i kong Fredriks tid. ${ }^{1}$ Få år etter Hans Egede kom til Grønland først på 1700-tallet, var Fredriksholms Kanal i 1724 åsted for det som i ettertid kalles "Det grønlandske Optog". Denne begivenheten regnes for den første "koloniutstilling" i Danmark. ${ }^{2}$

Fra slutten av 1700-tallet uttrykker kongehusets store prosjekt med Nordmandsdalen ved Fredensborg slott på Nord-Sjælland noe av den samme interessen. Der finner vi statuer av 3 samer blant statuene fra Norge og Færøyene. ${ }^{3}$ Samtidig kjenner vi til at samer med rein ble brakt til kongens hoff for å vise sine ferdigheter, i likhet med grønlenderne tidligere. I Sverige foregikk det samme i Stockholm. ${ }^{4}$ Vi kan imidlertid her ikke snakke om utstilling, men om korte opptredener for kongene og deres gjester.

\section{"Mr Bullock's Exhibition OF LAPLANDERS"}

En av de første virkelig store begivenheter som plasserte mennesket som utstillingsobjekt, skjedde i London i 1822-1823. Museumsog showmannen William Bullock hentet et antall rein og Rørossamefamilien Jens Thomasen Holm (ca. 1794-1834), kona Karen Christiansdatter og deres vesle sønn på 3-4 år til London. Bullock hadde blitt overbevist om at den hvite mosen en fant i høylandet $\mathrm{i}$ store deler av England, også i områdene nær London, kunne egne seg for reinsdyr. Samefamilien ble med for å passe reinen, Bullock hadde også nokså sikkert andre planer for dem.

William Bullock (ca. 1773-1849) var "ei stor stjerne på det tidlige 1800-talls museumsscene, men er nærmest glemt idag", sier museumshistorikeren Edward P. Alexander. ${ }^{5}$ Bullock startet fra omkr. 1795 å bygge opp samlinger, og i april 1812 åpnet han sitt "London Museum of Natural History and Pantherion". Det store museums- og utstillingsbygget på Piccadilly kalte han Egyptian Temple. Det gikk snart under navnet Egyptian Hall, og var et viktig element $i$ Londons aktivitetstilbud inntil det ble revet i 1905 . Her stilte Bullock ut alt tenkelig innenfor kunst, antikviteter og naturhistorie. En av Bullocks største suksesser var utstillingen av Napoleons store vogn, som han sammen med flere gjenstander ellers hadde kjøpt etter slaget ved Waterloo. Hans talent vises ikke minst i det at han greidde å oppspore Napoleons hollanske vognmann, Jean Hornn, som hadde overlevd slaget med "bare" en knust arm, og fikk han med på utstillingsåpningen samtidig som han publiserte hans fortelling fra tiden med keiseren. Over 80.000 besøkende så Napoleonsutstillingen i London, og på en etterfølgende turné i de store byene i England, Skottland och Irland i 1817-1818 har 800.000 sett den. Bullock skal på denne utstillingen ha gjort et solid overskudd på $£ 26.000$. $^{6}$

Det var ingen tvil om at hans samiske prosjekt hadde samme intensjoner i både å nå et stort publikum og i å gi et godt økonomisk utbytte. Etter det vi skal tro kan Jens Thomasen ha vært ukjent med Bullocks egentlige planer da han ble med for å passe reinsdyrene. Vi vet Jens var opptatt av å undersøke om det var ulv i England, ettersom det ville være en fare for reinsdyrene. Og på Piccadilly var det neppe større ulvefare då enn nå.

I Egyptian Hall fikk Bullock kaptein Arthur de Capell Brooke, som hadde reist $\mathrm{i}$ 
62 Nord-Norge i 1820, til å rettlede oppbyggingen av et stort vinterlandskap med høye fjelltopper og teltlignende kojer. På veggene var det utstilt forskjellige typiske samiske gjenstander: klær, snøskor, ski, reinshorn m.m. ${ }^{7}$

Bullock gjorde et stort PR-arbeid, bl.a. med trykking av en 36 siders katalog, og med store presentasjoner i ulike magasiner og aviser. Vi kjenner også fire illustrasjoner som ble publisert, og som tydelig forteller hvilken begivenhet utstillingen var. I artikkelen gjengir vi det av disse fire som kanskje gir mest informasjon om selve utstillingen, Thomas Rowlandsons trykk fra $1822 .^{8}$

Samefamilien opptrådte i Egyptian Hall med åtte reinsdyr. Bullock hadde skaffet en oversetter så publikum kunne snakke med Jens og Karen, og stolte foreldre kunne la sine barn få sitte på reinsdyrene. Publikum var henrykt og utstillingen fikk 58.000 besøkende på de første seks uker. Dette var en kjempebegivenhet i London og London Times skrev:

Many a lady of rank and title might with great advantage take a lesson in manners from the unaffected and graceful self-possession of the Lapland female. ${ }^{9}$

Så långt var dette også en økonomisk suksess for Bullock som tjente $£ 100$ pr. dag. Men det skjedde ikke uten problemer. Allerede ved mottakelsen i England av de 12 reinsdyrene fikk de vanskeligheter, ettersom tollmyndigheten ikke hadde tariffer for rein i sine skjema. Dette gjorde at de ble holdt igjen i tollen, og 8 av dyrene døde allerede da. Seinere viste det seg at både klimaet og fôret ikke passet reinen, så etter hvert døde alle. Bullock erstattet dem med wapti, amerikanske hjortedyr.

Utstillingen ser ut til å ha pågått i to deler; første del i januar-april 1822, deretter har samefamilien vært tilbake i Norge - kanskje for å skaffe flere reinsdyr. I oktober var de i
London igjen. I likhet med Napoleonutstillingen dro også denne på vandring til de andre større byene. Presset ble imidlertid for stort på de to unge samene, og det ble problemer bl.a. med alkohol. Tragisk var det også at den vesle gutten deres døde. ${ }^{10}$

Tilbake i Rørosfjellene fikk imidlertid Jens og Karen to nye gutter, Johan Christian i 1824 og Niels i 1827. I arkivene finner vi fra 1827 sogneprest Aschenbergs omtale av dem:

Jens Thomasen og Hustrue Karen har her ladet døbe for et Par Aar siden et Barn, have ellers i mange Aar opholdet sig ved Stavanger, senere i Engelland hos Hr. Balloch i London, der har viist ham, Kone og Dyr om for Penge i London, øvrige Engelland, Irland og Dublin. Da Rhens Dyrene døde, entledigedes de. ${ }^{11}$

De hadde da virkelig også noe å fortelle på Rørosvidda fra si utenlandsreise. Men bare 40 år gammel døde Jens Thomasen i mai 1834 på ei reise til Strinda ved Trondheim. Hans opplevelser hadde likevel satt djupe spor, for mer enn 50 år etter (1889) ble han fortsatt blant samene husket som "Engelsk-Jens". ${ }^{12}$

\section{Carl Hagenbeck OG "LAPPELEIR" - TURNÉENE}

Dyrehandleren Carl Hagenbeck i Hamburg kom i en 50-årsperiode til å bli Europas fremste aktør i utstilling av mennesker. Han drev sin virksomhet rettet mot zoologiske hager, og i tråd med tidas ledende tankestrømninger var ikke spranget langt fra dyr til eksotiske folkeslag. Hagenbeck har selv beskrevet hvordan han kom igang med "folkeutstillingene", som han kalte dem:

Det var i Aaret 1874, at jeg i et Brev meddelte min gamle Ven, Dyremaleren Heinrich Leutemann - jeg husker ikke mere af hvilken Grund -, at jeg skulle indføre en Renhjord paa 30 Stykker for at kunne forsyne 
forskellige zoologiske Haver med disse Dyr. Kunstneren skrev saa til mig, at det sikkert vilde vække stor Interesse, hvis jeg vilde lade en Lappe-Familie følge med Rensdyrene, og saa naturligvis lade den medføre sine Telte, Vaaben, Slæder og hele sit Husudstyr. Hvad der foresvævede Kunstneren i hans Brev, var sikkert kun det maleriske, nordiske Billede, som han ikke formaaede at forestille sig i skarp Fuldkommenhed uden Mennesker og Dyr og om muligt en vinterlig Baggrund. Men i dette Forslag laa gemt den heldige Idé om Folkeudstillinger, der i de Aar hægtede sig sammen til en broget Kæde. ${ }^{13}$

I september 1874 fikk han så til Tyskland den første gruppa på 6 samer fra Karesuando i Sverige. De ble vist fram først i Hamburg, deretter i Berlin og Leipzig. Hagenbeck kalte arrangementet for "antropologisch-zoologische Ausstellung", og knyttet derved visningene til datidas vitenskapelige termer. Dette ble også fremhevet ved at han arrangerte utstillingene i zoologiske hager. Der det fantes vitenskapsmenn ser disse også ut til å ha stilt villig opp for å utføre sin "armchair"antropologi knyttet til visningene. Deres deltakelse forsterket intrykket av seriøsitet, og Hagenbeck kunne betone den viktige opplysningsverdien virksomheten hadde. Ettersom virksomheten pågikk i mer enn 50 år, ble det også store fortjenester å dele mellom dyrehandleren og Europas mange zoologiske hager. Ja, ifølge Hagenbeck, så "bragte dyrehandelen i disse Aar store Tab, og det var ene og alene Folkeudstillingerne, som dekket Deficit' et”. ${ }^{14}$ Hagenbeck gir også sin framstilling av samene han brakte på utstilling:

Gæsterne fra det høje Nord havde jo ikke Spor af Begreb om Forevisninger og hvad dertil hører, og der blev ikke givet nogen som helst "Forestilling". ... Skønne kunde man just ikke kalde vore Gæster. Deres Hudfarve er et smudsigt Gult, deres runde Hoved er bevokset med stride, sorte Haar, deres Øjne er lidt skraat stillede, Næsen lille og flad. Derimot er Benbygningen meget fin og zart, og mindre Hænder og Fødder end hos Lapperne har man kun Lejlighed til at beundre hos Eskimo-Skønheder. Det var en Fornøjelse at se, hvorledes de indfangede Rensdyrene ved Hjælp af en Kasteløkke, hvor behændigt de tumlede med Slæderne, og paa hvor hensigtsmæssig en Maade Opbygningen og Nedtagningen af Teltene gik for sig. Stor Interesse vakte hver Gang Renernes Malking, og den lille Lappekone gjorde ligefrem Furore, naar hun i sin Naivitet og uden at lade sig forstyrre af Publikums Tilstedeværelse gav sit Pattebarn Bryst. Vore Gæster var uforfalskede Naturmennesker, ... Lige fra den første Dag af var Publikum ligefrem entusiasmeret, hvad vel tildels maa tilskrives den absolute Nyhed ikke blot af denne Opvisning, men af saadane Fremstillinger i det hele. ${ }^{15}$

Hagenbecks suksess med samegruppa, det "første førsøg paa en antropologisk-zoologisk udstilling", som Hagenbeck sier, ga mersmak:

Isen var saa at sige brudt, og jeg var bleven overbevist om, at den Slags Fremstillinger vilde finde Anklang hos Publikum paa Grund af deres store instruktive Værdi. Jeg saa mig i Tankerne om efter andre Folkeslag, som det kunde være værd at udstille. ${ }^{16}$

Og han fant dem. I række og rad kom nå nubier, eskimoer, somaliere, kalmukker, indianere, singalesere og hottentotter. ${ }^{17}$ Ei gruppe patagoniere måtte imidlertid hjemsendes på grunn av hjemlengsel. Ei gruppe Labradoreskimoer ble sjuke av en slags infeksjon og alle døde. Det skapte et midlertidig avbrudd i virksomheten. ${ }^{18}$

\section{SAmefamilier fra Røros OG HELE Norden}

Gunnar Broberg har beskrevet mer enn 20 samegrupper på utstillingsreise i Europa. Allerede 1875-76 var neste gruppe på 8 samer 
64 fra Malå i Sverige på farten. I 1878 hadde Hagenbeck skaffet seg en egen norsk agent, Adrian Jakobsen, som fikk med seg ei samegruppe på 10 personer fra Kautokeino. I London finner vi i 1886 ei gruppe på 7 samer fra Karasjok. Om lag på samme tid er ei gruppe Jämtlandssamer i England. Det gikk imidlertid ikke bedre for disse enn att agent Nilsson fra Skåne stakk av med kassa, og forlot samene i London, der de så måtte livnære seg med bakerarbeid. Etter å ha fătt hjelp av det svenske konsulatet, kom de seg hjem. Men ved konsulatet tvilte de på deres herkomst, og først etter at en av samene leste høyt fra en samisk bibel ble de trodd. ${ }^{19}$

I 1888 var 7 samer fra Undersåker i Jämtland i Berlin sammen med 8 rein og lapphundene "Carmen og Plum". De viste seg fram i Zoologischer Garten i 5 timer om dagen, og på en søndag trengte 7.000 mennesker seg fram for å se.

Flere Rørossamer deltok både ved verdensutstillingen i Paris i 1889 og i Chicago 1893. En av samefamiliene i Chicago var familien til den da svenske samen Daniel Mortenson. Han ble senere en av de mest markante lederskikkelser i samenes politiske og kulturelle kamp i Norge, bl.a. som utgiver og redaktør av den sørsamiske avisa "Waren Sardne" fra $1910 .{ }^{20}$ Verdensutstillingen i Chicago rommet den til da største presentasjon av ulike etniske grupper, og universitetet i Chicago arrangerte en "Field school of anthropology" under utstillingen. Blant de som organiserte disse delene av utstillingene med "primitive" folkeslag finner vi også Franz Boas, som regnes som den egentlige grunnlegger av amerikansk kulturantropologi. I Chicago møter vi i 1893 også Hagenbecks agent, nordmannen Adrian Jakobsen. Han driver storhandel med samiske kulturgjenstander til de etnografiske museer som var under framvekst i de fleste europeiske land. ${ }^{21}$

Også i 1893 var rørossamer engasjert på "Europa-turné". Jon Mortenson og kona Louise var av de som var med i denne gruppa. På turen ble dattera Anna født i Hannover. En plakat fra denne turen er bevart på museet i Hamburg. ${ }^{22}$

Turnéene i Europa fortsatte også etter århundreskiftet. Vi kjenner til ei stor gruppe samer fra nord-Finland som reiste i 1909, og i 1911 er et 50-tall samer fra Kiruna i Tyskland. Spesiell oppsikt vakte det i 1913 da ei gruppe norske samer ble forlatt av sin impressario i Budapests zoologiske hage, og under nokså vanskelige forhold måtte gå til "streik" før de fikk hjelp av den norske konsulen til å ordne opp.

Likevel virker det som de fleste gruppene på reise har greidd seg bra. For Rørossamene ser vi ihvertfall at også nye generasjoner deltar. I 1926 reiste sønnen til Daniel Mortenson, Mathias Mortenson, med kone og fire barn for Hagenbeck i ei gruppe hvor det også var med svenske samer i 37 tyske byer gjennom 8-9 måneder. Igjen var det Adrian Jakobsen som organiserte det hele, i likhet med en lignende tur i $1930 .{ }^{23}$

I 1933 engasjerte en dansk sirkusdirektør to av Daniel Mortensons sønner på stor turné med "lappeleir" i Danmark, Sveits, Tyskland og Frankrike. "De fikk komme ut og se litt av verden, men de ble grundig lei av å bli glodd på nærmest som steinaldermennesker..." kan vi lese i beskrivelsene etterpå. ${ }^{24}$

Vi kan også komme datidas oppfatning nærmere ved å lese fra markedsføringen for dette prosjektet i 1933. I ei annonse het det: "Der er langt fra Lappernes primitive Samfund til vort eget civiliserede", og i brosjyra som ble laget: 


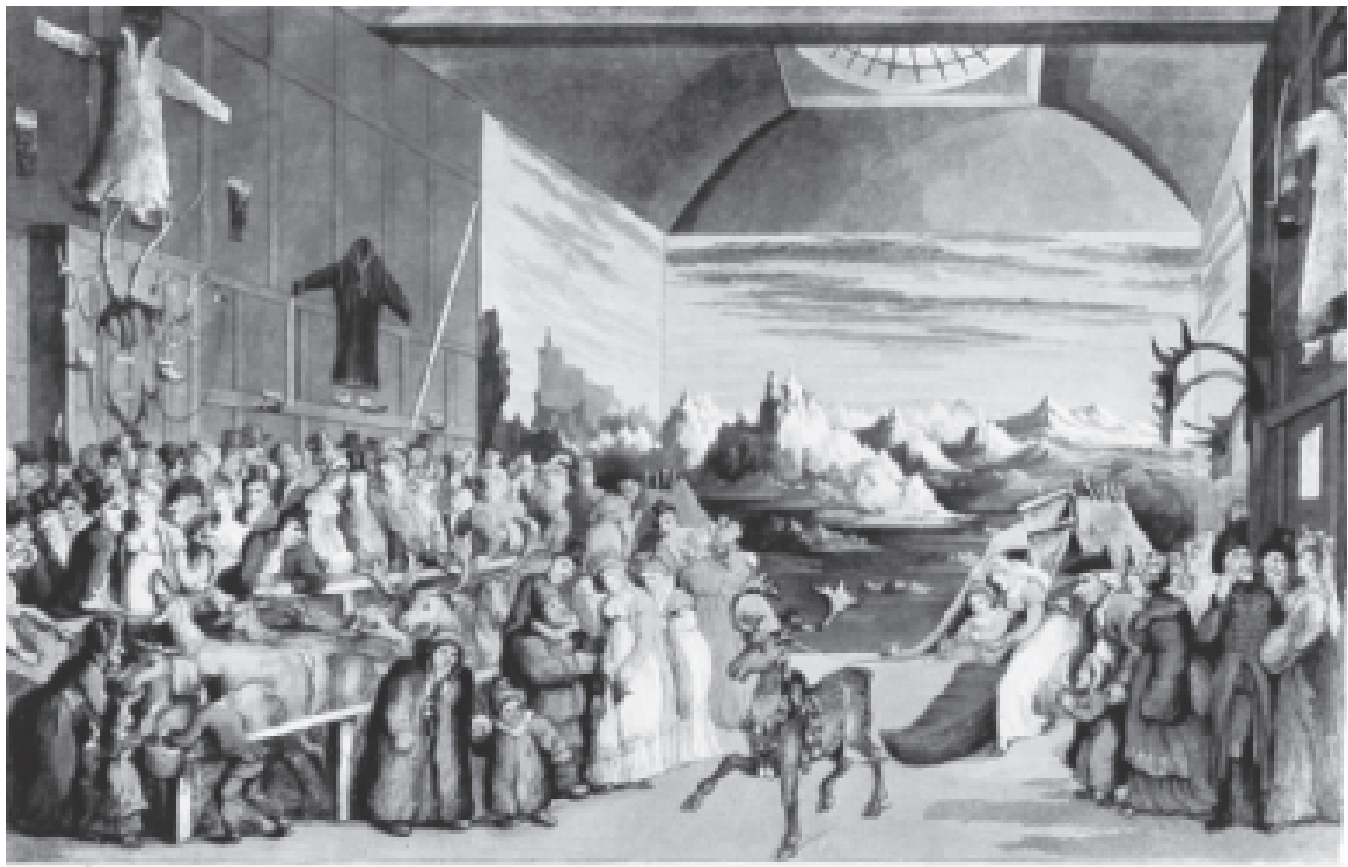

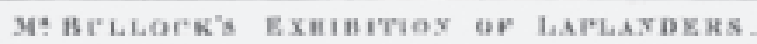

Mr Bullocks utställning av "lapplänningar". Tecknad och graverad av Thomas Rowlandson (1756-1827). Färglagd etsning utgiven 8 februari 1822 av R. Ackermann, London. Bildyta 30x45,2 cm. Foto: Museiverket, Helsingfors.

Lappen har ikke noget imod at man interesseret studerer hans Ejendommeligheder, naar vi blot ikke glemmer, at han er vort Medmenneske - ganske vist med en mere primitiv Kultur end vor. Han sætter stor Pris paa Penge og fryder sig hjerteligt over enhver Opmærksomhed, hvormed den Fremmede honorerer hans smaa Villigheder - f.Eks. at lade sig fotografere. Og et Billede af en Lappe-Familie i Naturtilstand kan før vi ved det blive et Billede fra en Tid der svandt. Jernbaner, Biler og Telefon har bragt Kulturen op til Vildmarken, hvor Lappen før herskede uindskrænket, og den Tid er maaske ikke fjern, da Nordens sidste Nomade har gjort sin sidste Rejse. ${ }^{25}$

\section{"LAPPELEIRER" \\ OG UTENLANDSTURISTER I NORGE}

På slutten av 1800-tallet hadde utenlandsturismen for alvor nådd Norge. Den var imidlertid i sterk grad konsentrert til kystområdene med størst vekt på vestlandsfjordene. En viss Nordkapp-turisme var igang, noe som for omkring 100 år siden årlig betød at ca. 1.600 utlendinger kom dit med turistskip. Disse turistskipene anløp Tromsø, der det var mulig å komme opp til samene i Tromsdalen. En konkurrerende "lappeleir" var også anlagt i 
66 Harstad, likeledes i Hammerfest, "som syntes at deres Lappeleir var mere berettiget til at faa Besøg af Turisterne, da den var i Finmarken, Lappernes naturlige Hjem" ${ }^{26}$

Men størstedelen av turistene kom aldri så langt nord. De siste par tiår av 1800-tallet lå tallet på utenlandsturister i Norge årlig på ca. 15-20.000. Etter århundreskiftet fordoblet det seg. ${ }^{27}$ I utlendingenes reisehåndböker var samene beskrevet, men de færreste hadde mulighet til å finne dem.

I 1896 ble det derfor blant andre under medvirkning av Cook's reisebyrå stiftet et aksjeselskap i Bergen som skulle anlegge en "Lappeleir for en lappefamilie med et par Telte, en Gamme og et Snes Rensdyr, samt en Pavillion, hvor Forfriskninger kunde serveres". ${ }^{28}$

Det var Ferdinand Bremer som fremmet ideen. Han drev skipsmeglerforretning i Levanger og Härnösand, med bigesjeft i å skaffe levende dyr til zoologiske hager og å engasjere samefamilier og reinsdyr til utstillinger $i$ utlandet. I tilleggg drev han også noe som reisefører for Cooks reisebyrå i Bergen. Bremer fortalte at han kjente "en Lappefamilie paa Meraker bestaaende af 4 Personer, Mand og Kone med to Døtre, som havde været paa Chicagoudstillingen". ${ }^{29}$

Anlegget for utstillingen ble bygd opp etter planene i Bjørndalen på ei halvøy i Tindebekkvannet omkr. 4 km. fra Bergen. Bergenserne kunne komme dit med ferge til Laksevåg, fra turistskipene ble det satt opp hestevogner. Samefamilien kom fra Storlien, og fikk reinlav sendt med tog fra Røros til fôr for reinsdyrene. Men på tross av 8.000 besøkende i første driftsår 1897 , dekket prosjektet ikke utgiftene. Det var derimot utsikter for at det skulle gå bedre i 1898, og kreditorene gikk med på et år til. For å spare penger bestemte ledelsen seg nå for å hente mose til reinen på Hardangervidda og ikke fra Røros. Dett skulle vise seg å bli et alvorlig mistak. Det ble ikke nok fôr, og halvparten av reinen måtte slaktes, etter masse avisskriverier. "Men Aktieselskapet var insolvent, og Spekulationen viste sig redningsløst forfeilet”, skrev Cook's Norgesrepresentant. Enden på det hele i 1898 var at investorene for å få igjen mest mulig av pengene sine, eksporterte hele "Lappeleiren" til Nederland: "Rensdyrene og Teltene samt Lappefamilien blev derfor afsendt med den hollandske Dampbaat 'Ingrid' til Rotterdam". ${ }^{30}$

\section{UTVIKLINGENS "FRAMSKRITT",} VITENSKAP, UTSTILLINGER, MUSEER

I Bullocks store utstilling i London er framstillingen av de "fremmede" flyttet ut av hoffene og de priviligerte kretser og til en åpen offentlighet. På 1800-tallet plasserer institusjoner som museer, zoologiske hager og store utstillinger seg nettopp som viktige elementer i konstruksjonen av en ny borgerlig offentlighetskultur. Særlig tydelig er dette i gjennomføringen av de store verdensutstillingene, der den framvoksende industrikulturen fra midten av 1800-tallet er en drivende kraft.

England var lengst framme, også i det å ha behov for å legitimere og spre populariserende holdninger knyttet til sin imperialistiske ideologi. De første store utstillingene arrangeres derfor i London 1851 og 1862. Deretter tar Frankrike over med verdensutstillinger i Paris 1867, 1878 og 1889. USA markerer seg også med utstillingene i Philadelphia 1876 og Chicago 1893. Som vi allerede har vist, ble "primitive" folkeslag framstilt ved alle disse utstillingene, som en kontrast til og bevis på 
framskrittets suksess og den vestlige sivilisasjons ledende rolle. ${ }^{31}$

I 1859 kom Charles Darwins "On the Origin of Species". Sammen med naturvitenskapenes generelle store betydning i samfunnet, ga dette et tilsynelatende vitenskapelig grunnlag for å plassere samene og andre "primitive" folk som biologisk laverestående. Hagenbecks utstillingsvirksomhet i zoologiske hager forsterket dette bildet.

Professorer og andre vitenskapsmenn var alltid tilgjengelige for å fortelle om samenes og andre folkeslags nær forestående undergang, slik som professor i medisin Alexander Ecker ved Freiburguniversitetet, som i 1875 ved ei samegruppes besøk kaller de "eine Art Völkerruine, ein Überbleibsel”, en rest av et stort folk som er trengt lengre og lengre mot nord, "und in eine wohl nicht allzuferne Zeit aufgehört haben wird zu existieren". ${ }^{32}$ Undergangen var nær forestående - og dette gjorde det enda mer nødvendig for publikum å passe på å få se dem. Ingen syntes å legge vekt på at argumentet ble brukt tiår etter tiår, og som vist foran, fortsatt i forbindelse med Rørossamene i 1933 - 50 år etter. Mange vil vel si at argumentasjonen etter denne tankegangen heller ikke stoppet opp da.

Den samme oppfatningen avspeiles i museenes forhold til samene, som ved opprettelsen i 1850-åra av Etnografisk Museum i Oslo. Museets samlinger ble til samtidig med at Britisk Museum etter 1851 skulle etablere etnografiske samlinger i "The People's Palace" i deler av Krystallpalasset fra verdensutstillingen samme år. Universitetet i Norge fikk da henvendelse om de ikke kunne skaffe samiske samlinger til London i bytte mot en samling etnografiske gjenstander fra Borneo og Sumatra. Tilbudet ble akseptert, og det ble samlet inn dobbelt sett samiske gjenstander, slik at et nyetablert etnografisk museum i Norge også fikk ett samisk materiale i sin gjenstandsstamme. I 1857 var de etnografiske samlingen tilgjengelige for publikum. Samlingen omfattet da ca. 240 gjenstander, og dette året regnes som museets grunnleggingsår. ${ }^{33}$ Etableringen av Etnografisk Museum illustrerer altså den tydelige sammenhengen mellom verdensutstillingene og museumsutviklingen gjennom andre halvdel av 1800-tallet.

I Sverige ble det ikke etablert noe eget etnografisk museum på denne tida, men de "primitive" folkeslag fikk sin plass i Naturhistoriska Riksmuseet. Og som Gunnar Broberg sier:

I en sådan inramning måste samen mer uppfattas som naturföreteelse än som kulturvarelse, mer som asiat än som skandinav. ${ }^{34}$

Professor Yngvar Nielsen (1843-1916) var leder for Etnografisk Museum 1877-1915. I forbindelse med 100-årsmarkeringen av Norges selvstændighet i 1914, ble det utgitt et praktverk i flere bind om land og folk. Her beskriver Yngvar Nielsen samene, eller med tidas språk "finnene", slik:

Racen har ikke hat let for at tilegne sig en høiere civilisation; den naar gjerne kun til et visst trin og stanser dermed, idet den i sit inderste føler en motsætning til denne kultur, som ikke kan overvindes.

Nielsen må imidlertid vedgå at det er samer som har blitt velutdannede som prester, forfattere og til og med som Isak Saba, stortingsrepresentant, men svaret på dette henter han fra sin skolelærdom om tysk grammatikk, ”om ikke tvertimot de faa undtagelser nærmest kun skulde tjene til at bestyrke regelen".

"Finnen ligger ikke for de høiere ting”, slår Nielsen fast, "Han har ingen musikalske in- 
68 strumenter, og den såkaldte juoiging svarer kun ufuldkomment til andre folkeslags digtekunst”.

Nielsen peker på at samene ikke har gamle tradisjoner, og at det er deres naboer som gjennom "videnskabelige undersøkelser" har belyst deres fortid, språk og situasjon i dag.

Deres syn gaar sjelden ut over øieblikkets behov, og de er lykkelige, naar de blot kan faa dette opfyldt. De synes heller ikke let at kunne bringes til at sætte sig høiere maal, og derfor maa dommen bli den, at de endnu ikke er naadd langt frem. ${ }^{35}$

Denne "dommen", som museumsmannen Yngvar Nielsen feller over samene, er en opptreden fra museets side som virker svært fremmed for oss i dag. Men i samtida var den neppe det. Slike "spøkelser i skapene" er derfor noe vi fort finner når vi studerer museene og hvordan deres samlinger er blitt til.

\section{ETTERORD}

Vi har i artikkelen møtt samene som levende utstillingsobjekter i forrige hundreår och langt inn i dette. En studie av samene i utstillinger og museer gjennom de siste 60 år ville fortelle ei noe annerledes historie. I 1949 ble det bestemt at de samiske samlingene i Oslo skulle overføres fra Etnografisk Museum til Norsk Folkemuseum. Samene fikk som norske borgere aksept for at deres kultur måtte utstilles sammen med norsk kultur fra andre deler av landet, og som det da ble uttrykt, ikke sammen med "kulturformer fra negrer, indianerer og andre 'primitive"”. ${ }^{36}$

Gradvis ble også troen på evolusjonismens og den avledede socialdarwinismens nødvendige utryddelse av samene og andre folkeslag, erstattet av større forståelse og respekt for urbefolkningenes rettigheter. Museenes og vi- tenskapens roller er i mange tilfeller blitt endret. Blant annet vil en studie av de siste 60 års historie også fortelle om at det samiske samfunnet startet ein egen kulturformidling og museumsvirksomhet. Etter å ha sett utviklingen med egne samiske museer omkr. 1970, var heller ikke lederen av Etnografisk Museum lenger sikker på at overflyttingen av de samiske samlinger til Norsk Folkemuseum omkr. 1950 hadde vært så riktig. "Hadde vi den gangen kunnet ane den utviklinga som har foregått mellom samene seinere, ville Etnografisk Museum kan hende ha disponert annleits", sa museets leder Gutorm Gjessing. ${ }^{37}$

Perspektivet på samekulturen og samenes plass i museumsbildet er i dag fullstendig annerledes enn det perspektivet på framtida en fant i de "antropologisk-zoologiske" utstillingers tid. I dag blir det også stadig tydeligere at historien om dette kanskje mer er historien om den vestlige sivilisasjonen, nemlig den moderne framskrittstenkningens vei mot sitt endedikt, enn det er historien om utstilte samer. Den vestlige sivilisasjon må altså nå flytte blikket mot det "fremmede" fra de "andre", og rette det mot seg selv.

\section{Noter}

- Artikkelen er blitt til takket være gode innspill fra Marc Maure, Inge Meldgaard og Anders Løøv. Den publicerades ursprungligen i "dugnad". Tidsskrift for etnologi 1995/1.

1. Dam-Mikkelsen/Lundbæk 1980:1-5.

2. Schou 1988:58.

3. Noss 1977:119-123.

4. Broberg 1981:28-29.

5. Alexander 1985:117.

6. Ibid: $125-126$.

7. Kaptein Arthur de Capell Brooke hadde reist gjennom hele Norge og til Nordkapp i 1820. 
Om reisen se Helberg 1944. Helberg skriver (s. 34) at Bullock reiste til Røros 1822 og fikk samefamilien med til London. Dette samsvarer ikke med andre framstillinger som sier Bullock traf samene i Stavanger, se Altick 1978:273.

8. (Etter original utlånt ved Cappelens Antikvariat, Oslo.) Annat original vid omtrycket.

9. Times, London 21. Januar 1822, sitert fra Altick 1978:274.

10. Altick 1978:273-275, Broberg 1981:29, Alexander 1985:130-131. Både Broberg og Alexander bygger i vesentlig grad på Altick.

11. Kvikne 1950:278.

12. Lappekommisjonen av 1889 samlet ærklæringer om sørsamiske bruksretter. I vitnemålene er Jens Thomasen omtalt på sidene 19, 65 og $104 \mathrm{i}$ kildeutgaven utarbeidet av Anders Løøv 1991.

13. Hagenbeck 1911:47.

14. Ibid: 53.

15. Ibid: $48-49$.

16. Ibid: 50 .

17. Zippelius 1986:420.

18. Broberg 1981:48.

19. Ibid: 33 .

20. Kvikne 1950:292-295.

21. Prisliste bevart i Museum für Völkerkunde i Hamburg, Broberg 1981:58.

22. Kvikne 1950:299.

23. Ibid: 299-300, Broberg1981:35-36.

24. Kvikne 1950:298-299.

25. Ibid: 291.

26. Scarlett 1922:96.

27. Ibid: 18.

28. Ibid: 97.

29. Ibid: 98 .

30. Ibid: $161-162$.

31. Ekström 1994:18-95.

32. Ecker, Alexander: Lappland und die Lappländer. Vortrag. Freiburg 1878. Gjengitt her etter Broberg 1981:49.

33. Nielsen 1907:6-14.
34. Broberg 1981:59. Det var først i 1935 at de samiske samlingene ble flyttet fra Naturhistoriska Riksmuseet til Nordiska Museet.

35. Nielsen 1914:113.

36. Gjessing 1973:142.

37. Ibid. Om samiske museer og samisk museumsarbeid, se bl.a. Museumsnytts temanummer om samiske museer 1988 og Fjellheim 1991.

\section{Summary}

This paper has grown out of the author's $\mathrm{PhD}$ dissertation in museology concerning the construction of the cultural heritage of Røros, a small mountain community in central Norway. The South-Sami people of that area have been involved in the museum's activities in this century, but when we look as far back as 1822-23 we see that a Sami family from Røros was the star attraction of a large museum exhibition in London. Using living human beings in exhibitions was to become an important feature of zoological gardens and the great world exhibitions of the late 19th and early 20th centuries. The German wild-animal dealer, Carl Hagenbeck, was a leading figure in this movement, featuring a group of Swedish Sami people in his first "antropologisch-zoologische Ausstellung" in 1874. Following this, Sami families were sent on tour throughout Europe virtually every summer. In Norway "Lapp tent camps" were also displayed for the special benefit of foreign tourists.

Hagenbeck's exhibitions helped to bring such shows of exotic peoples into the rapidly growing contemporary scientific milieu. In 1859 Charles Darwin had published his On the Origin of Species, and it was not uncommon for scientists to consider different groups of "primitive" peoples as being racially inferior. Exhibitions of human beings, such as the Sami and other "primitives", also helped to create and reinforce stereotypes which were founded on myth and misunderstandings. Moreover, the exhibitions served to underscore the supposed importance of promoting modern concepts of 
70 progress, with the underlying assumption that Western civilization had to play a leading role in this.

The author concludes by showing how such presentations in world exhibitions, combined with the scientific views of the time, were instrumental in the establishment of ethnographic museums. During the last fifty years, Sami museum collections in Norway have changed location at the same pace as the changing status of the Sami themselves. From about 1970 onwards, we find the establishment of purely Sami museums.

The history of living beings in "anthropological zoological" exhibitions must be considered more as an aspect of the history of Western civilization and its modern concept of progress, than as a history of "primitive" peoples. In our time the focal point has changed from the observed object to the observer.

\section{REFERERT LITTERATUR}

Alexander, Edward P. "William Bullock: Little-Remembered Museologist and Showman." Curator 28, 1985/2, s. 117-147.

Altick, Richard D.: The Shows of London. Massachusetts og London 1978.

Broberg, Gunnar: Lappkaravaner på villovägar. Lychnos $1981-82$, s. 27-86.

Dam-Mikkelsen, Bente og Lundbæk, Torben: Etnografiske genstande $i$ Det kongelige danske Kunstkammer 1650-1800. København 1980.

Ekström, Anders: Den utställda världen: Stockholmsutställningen 1897 och 1800-talets världsutställningar. Stockholm 1994.

Fjellheim, Sverre: Kulturell kompetanse og områdetilhørighet. Snåsa 1991.

Gjessing, Gutorm: Norge i Sameland. Oslo 1973.

Hagenbeck, Carl: Dyr og Mennesker. København og Kristiania 1999.

Helberg, Claus: De forste vandrere. Oslo 1994.

Kvikne, Olav: Samene og reindriften på Rørosvidda. I: Rørosboka bind 1, Røros (1941-) 1950,
s. $270-300$.

Løøv, Anders (red.): Lappekommisjonen av 1889. Del 1. DOVLETJE. Kildeskrifter til sørsamisk historie I. Snåsa 1991.

Museumsnytt, temanummer om samiske museer 1988/4

Nielsen, Yngvar: Finnene. I: Brøgger, W.C. et al. (red.) Norge 1814-1914. Kristiania 1914, s. 112-119.

Nielsen, Yngvar: Universitetets Etnografiske Samlinger 1857-1907. Christiania 1907.

Noss, Aagot: Statuene i Nordmandsdalen. Oslo 1977. Rydell, Robert W.: All the Worlds Fair. Chicago og London 1984.

Scarlett, Ferdinand: Turistlandet Norge II. Del, Kristiania 1922.

Schou, Jesper: Etnografiske karavaner. Stofskifte 16 1987/88. s. 55-87.

Zippelius, Adelhart: Der Mensch als lebendes Exponat. I: Jeggle et al. (red.): Volkskultur in der Moderne. Reinbek bei Hamburg 1986, s. 410-429. 


\section{KAN VI VERNE}

\section{ET TELEFONNUMMER?}

\section{Om å velge framtidas kulturarv}

\section{John Aage Gjestrum}

Jeg har ikke sett på meg sjøl som gammel, men må kanskje snart skifte meining. I mine aller forste leveår på 1950-tallet bodde vi i huset til ei tante av min far. Der hadde vi telefon, og telefonnummeret var lett a huske, tro det eller ei-det var telefonnummer 1 . Det må da vere så spesielt at vi må kunne snakke om verneverdi?

I Vestre Toten fikk vi telefon i 1889, direkte knyttet til Christiania Telefonselskab. Den første bygningen spesielt bygget for telefonselskapet var ferdig i 1890 , tvers over veien for lensmannen. En av de første abonnementene var på garden Øfstås i Kjørkjebygda. Der holdt kommunelegen, kommunekassereren og poståpneren til.

På midten av 1970-tallet gjorde jeg intervjuer på lydband med flere av de eldste innbyggerne $i$ bygda. Ei nesten 100 år gammel kvinne som hadde vokst opp litt lenger vest $\mathrm{i}$ bygda, fortalte fra 1890-åra at de hver dag kikket over på den andre sida av dalen for å se værmeldingen. Emil Pedersen, poståpneren på Øfstås, hadde ei høg stang på garden der han heiste opp en firkant eller en trekant, eller begge figurene - alt ettersom hvordan været skulle bli. Øfstås ligger høyt i bygda så svært mange kunne se dit.

Jeg syntes dette hørte merkelig ut, og dro til Øfstås-gardene for å spørre om noen der kunne fortelle mer om værvarslingen. Jo, på et stabbur hadde en nabo tatt vare på firkanten - trekanten var borte.

Det skulle gå noen år før jeg fikk satt sammen bitene i dette til en helhet. Systemet med trekanten og firkanten var faktisk et system bl.a. jernbanen brukte. Hver dag fra og med 1884 gikk det ut værvarsel fra hovedstaden til oppslag på stasjonene på Østlandet, og enkelte tog hadde systemet med firkant og trekant bak på siste vogn, slik at de som bodde etter linja ved å se på toget kunne se værvarslet. Firkanten alene betød tørt vær, trekant over firkant varslet om utrygt vær, firkant alene meldte om at det ble regn og firkant over trekant betød oppklarende vær.

Ettersom det ikke kom noe tog på Toten før i 1902, var det nok med telefonens hjelp Emil Pedersen skaffet sitt værvarsel, som han så formidlet videre til alle de andre i bygda. Emil pensjonerte seg som poståpner, og sikkert også som værvarsler da jernbanen kom i 
72 1902. Postkontoret ble flyttet til stasjonen, i bunnen av dalen. Emil solgte også garden, men holdt av noen dekar der han bygde sin pensjonistvilla, Kytdalen, der han i 30 år framover pleide hagen og sine lokalhistoriske skriverier.

På slutten av 1900-tallet er det jeg som bor i Kytdalen. Telefonlinjene fra 1890 er byttet ut med nye. Og med samme sans for mulighetene i tekniske innovasjoner koblet jeg for noen år tilbake mitt modem og datamaskin opp til Oslo-nett, der Emil for mer enn 100 år siden koblet sitt telefonapparat til Christiania Telefonselskab. Mens Emil kunne varsle de andre bøndene i bygda om det var sikkert tørkevær i sikte for høyet, kan jeg fra samme sted arbeide på Umeå Universitetets dataanlegg i Nord-Sverige. Og resultatene kan så nås over hele verden av alle med en datamaskin tilkoblet internett.

\section{Mulig Kulturarv?}

Historien jeg har fortalt fra mitt nærmiljø er ikke særlig spesiell, annet enn for meg - ettersom jeg har levd i en del av den, og fătt overlevert noe av det som skjedde før mi tid Samtidig er det klart at det fra denne hundreårige historien finnes objekter, bygninger og anlegg som kan bli del av en definert kulturarv.

$\AA$ bevare et telefonnummer som kulturarv er neppe mulig - dessuten er vel telefonnummer 1 mer en kuriositet for meg enn noe av egentlig betydning for andre?

Firkanten i Emil Pedersens værmeldingssystem - ei kube på ca. 60 × 60 × $60 \mathrm{~cm}$ med grått lærret strukket på et treskjellett - sørget jeg for ble museumsgjenstand på Toten økomuseum. Likeens lydbåndet med fortellingen om dette. Telefonselskapets nybygg fra 1890 kjører jeg forbi på vei til kontoret hver dag. Bygningen og et lite uthus er stort sett eksteriørmessig uendret, men brukes nå som bolig og så vidt jeg vet er ikke huset vernet ved spesielle tiltak.

Min internett-oppkobling til Oslonett er ihvertfall ikke vernet - faktisk tilhører også det historien, ettersom Schibsted-nett tok over, og etter det igjen Telenor online. Modemet, datamaskinen, de første internett-sidene som ble lagt ut, www-leseren Mosaic og e-post-programmet Eudora finnes imidlertid enda, og kan bevares for framtida.

\section{Profesjonell og IKKE-PROFESJO- NELL KULTURARVSETABLERING}

Konstruksjonen av kulturarv er en kontinuerlig prosess, der både profesjonelle og ikkeprofesjonelle aktører deltar. En forutsetning for at noe kan bli kulturarv synes å være en type intersubjektiv og samfunnsrelatert overenskommelse om at bestemte objekter representerer verdier som er så viktige at objektene derfor må bevares for all framtid.

De intersubjektive overenskomstene etableres i helt ulike sosiale kontekster, der de profesjonelle antikvarer, konservatorer og museumsfolk utgjør én slik kontekst. Gapet mellom den profesjonelt definerte og forståtte kulturarven og den ikke-profesjonelle er svært ofte stort, og kan forstås som en motsetning mellom en profesjonell, disiplinrettet, oppsplittet og kognitivt verdsatt kulturarv på den ene sida, og kulturarv for den ikkeprofesjonelle med en emotiv og nærmest eksistensiell dimensjon på den andre sida.

De profesjonelle aktørene synes alltid å ha ønsket seg kontroll over feltet, og har «fantasert» om mulighetene for å etablere gyldige kriterier for hva som er verneverdig og hva 
som ikke er det. I dag kan det være grunn til å stille spørsmålstegn ved om det er mulig å etablere slike kriterier.

Det blir i dag konstituert kulturarv innenfor langt flere sosiale kontekster enn tidligere. Vi ser imidlertid ofte at det er mer allmenne trivselsverdier og en nostalgisk lengsel tilbake til «gode gamle dager» som er drivkraften.

\section{Musealisering \\ ELLER MUSEFISERING?}

Kulturarvs- og museumsområdet er et av vår tids store vekstområder. Opptattheten av ei virkelig eller innbilt fortid synes å være et karakteristisk kulturtrekk i hele den vestlige verden. Samtidig med at statlige myndigheter i Norge hadde slått fast at en ikke ønsket etablering av nye museer, fikk vi i de første åra på 1990-tallet et nytt museum i Norge hver 72. time. Nå er farten blitt mer moderat med «bare» 6 nye museer i måneden. Likevel er tallet på museer nesten blitt fordoblet på mindre enn 10 år.

Musealisering - det å tilkjenne et objekt en verdi og rett til «evig liv» er kanskje det nærmeste mennesket kommer drømmen om udødelighet. Musealiseringen innebærer også en tillegging av helt nytt meningsinnhold $i$ tingen/objektet. Det forteller nå like mye om måten det blir brukt på i et sosialt/kulturelt spill i nåtida, som om den fortida det representerer. Dette «spillet» med bruk av objekter fra fortida er også et maktspill. Noen behersker spillereglene og har de riktige midlene til å drive et slikt spill (dvs. har og opprettholder en bestemt type makt), og noen gjør det ikke (dvs. har ikke slik makt).

Den franske filosof og sosiolog Jean Baudrillard snakker ikke om musealisering, men om musefisering. Det er imidlertid samme fenomen han tar opp. For Baudrillard er den såkalte musealiserings-prosessen besatt med noe entydig negativt. Han ser i musefisering et fonetisk slektskap med infisering, for å assosiere med en sjukdoms utbredelse. Sammenfatter en Baudrillards musefiseringsbilde, blir det slik:

- Musefisering betyr, å sette noe i en tilstand der det ikke mer kan forandres og der det ikke kan dø. (Holdbarhet - bevegelseshemming - forstening i levende tilstand og innelukkethet).

- Musefisering betyr udødeliggjøring og «historiske vitnesbyrd». Forgjengelighet må tydelig kunne bli gjemt. Et materiellt og ideelt tanke- og funksjonstap.

- Musefisering er en voldtekt: I arkeologiens utgravingstilfelle blir eksplisitt voldsomheten til musefiseringen uttalt: Subjektet (vitenskapen) utrydder sitt objekt.

- Musefisering betyr at noe som tas ut av konteksten og bringes i en ny sammenheng og derved bestemt forandrer realitetsgraden til et objekt.

- Musefisering er en kunstig handling, der ting, mennesker, skikker blir satt i en kunstig tilstand. Bare skinnet av den gamle virkeligheten eksisterer fortsatt (Sturm 1990).

Betydningen av Baudrillards refleksjon om musefisering ligger $i$ at han gjør oppmerksom på de flytende overgangene mellom musefisering og nykonstruksjon, $-i$ en gradvis mer uoversiktelig simulert virkelighet. Baudrillard peker på at en dag er originalens historiske vitneutsagn blitt glemt, og skillet mellom simulakrum og virkelighet er virkelig borte.

Baudrillard er skeptisk overfor musefiseringshandlingen. Når det fra vitenskap og sivilisasjon blir innsatt midler for å redde den egne virkeligheten, fører det til akkurat det motsatte. Økningen i musefiseringstendensen kan derfor sees som et bevis på økende virkelighetsfjernet. 


\section{$74 \quad$ EpIlog}

Det er vanlig å si at hva som blir bevart og hva som blir kastet eller ødelagt nærmest er helt tilfeldig. Men er dette rett? Er det ikke heller slik at helt bestemte aktører i helt bestemte sosiale/kulturelle situasjoner foretar handlinger som er avgjørende og representerer konstituering av kulturarv og musealisering? Ofte sier vi at når en hel rekke ting/objekter i en periode ikke er bevart, så er det umistelige tap. Men er det sikkert? Er det mulig for oss idag på et objektivt faglig grunnlag å sortere ut den kulturarv som våre etterkommere om 75 år vil se som de mest verdifulle kulturminner og museumsobjekter?

Studier av kulturvern- og museumshistorie $i$ et lengre tidsperspektiv bakover viser at den mer generelle oppfatningen i fagmiljøene av hva som er verneverdig og hva som ikke er det, er grunnleggende endret ca. hvert 20. år.

For vel 20 år siden var jeg ut fra min museumsfaglige vurdering sikker på at Emil Pedersens gamle værmeldingsfirkant var bevaringsverdig. Men da hadde folkene på nabogarden allerede tatt vare på denne spesielle gjenstanden i 75 år. Kanskje er det også det som skjer med min første internett-oppkobling? At jeg ut fra en følelse av at dette representerte noe spesielt for meg unnlater å kaste mitt gamle Mosaic-program, den gamle datamaskinen og kanskje de første sidene jeg la ut på internett. Så vil det for meg være en del av min subjektive hukommelse, sammen med mitt kuriøse telefonnummer $1 \mathrm{og}$ mange andre minner som samler seg gjennom et liv. På et tidspunkt oppstår kanskje en situasjon da det blir viktig for noen å sette søkelyset på hva som skjedde de første åra på 1990tallet då verden plutselig ble bundet sammen på en helt ny måte.
Jeg vil derfor formulere følgende tese: Det er i samspillet over tid mellom det subjektive og det intersubjektive at kulturarven utkrystalliseres, - ikke i mulig definerbare objektive egenskaper ved objektene/gjenstandene.

Kanskje det til og med for meg om 20-30 år vil være mulig å finne likesinnede og danne en forening av folk med telefonnummer fra før automatiseringen. På et tidspunkt bør det både bli sjeldent nok og kanskje gi de rette nostalgiske vibrasjoner vi då kan føle at vi trenger?

\section{Noter}

- Texten publicerades ursprungligen i tidskriften "Fortidsvern", 1997/4.

- Jean Baudrillards bok heter Agonie des Realen. (1978) og omtalen her er hentet fra Eva Sturm: Museifizierung und Realitätsverlust, i Zacharias, W. (1990): Zeitphänomen Musealisierung. Essen, s. 99-113. 


\title{
KuLTURARV SOM HANDLING
}

\author{
John Aage Gjestrum
}

En studie av musealiseringen av Røros viser til ei 100-ärig historie om etablering, omdanning og ny etablering av kulturarv $i$ et lite norsk lokalsamfunn. Det er ikke "objektive" og "autentiske" egenskaper ved kulturarvobjektene som har skapt kulturarven. I stedet er den blitt til (og endret) i et spill der ulike aktører har hatt helt påvisbare nåtidige interesser å ivareta på de aktuelle tidspunkt. Tidsperspektivet viser at det da er helt ulike aktører som på ulike tidspunkt har interesse av à skape kulturarv.

Den 9. august i år åpnes i Norge et gigantisk vernebygg i glass over ruinene etter Hamar domkirke. Bygget er 40 meter høyt, 67 meter langt og har kostet 75 millioner norske kroner. Siden arbeidet med kulturminner i Norge tok fart etter dannelsen i 1844 av Fortidsminneforeningen (Foreningen til Norske Fortidsminnesmerkers Bevaring), har domkirkeruinen på Hamar hatt status som kulturarv - et minne om høgmiddelalderens norske storhetstid. Som kjent tok denne storhetstida slutt, og et av de konkrete uttrykk for dette er nettopp kirkeruinen på Hamar. Under sjuårskrigen gjennomførte en svensk hæravdeling i året 1567 en fullstendig utradering av de norske posisjoner i området og satte domkirken i brann.

Det stolte byggverk fra tida omkring bispedømmets opprettelse i 1152 ble fullstendig ødelagt, og bøndene i området benyttet i et par hundre år framover stein fra kirkebygget til kalkbrenning og egne byggearbeider. Inntil midten av forrige århundre, da minnene fra den tidligere nasjonale storhet ble kul- turarv. Det som da var igjen, var søylerekka etter midtskipets sørvegg.

- Det er det glade vanvidd, sier dekanus og førsteamanuensis Elisabeth Elster $i$ et avisintervju. Hun er kanskje den fremste ekspert i Norge på slike middelalderruiner. Å bygge et slikt glasshus over ruinene er uten mening, det finnes ikke noen faglige grunner til å gjøre dette. Ruinene er gjennomdokumentert og utforsket. All dokumentasjon er sikret for ettertiden og vitenskapen. Så hvorfor bruke 75 millioner på et glasshus?

På tross av betydelig motstand innenfor fagmiljøene er glasshuset på Hamar blitt bygget. Hvis dette ikke skjer som en faglig begrunnet bevaring av kulturarven, hvorfor blir det da realisert?

Er det kulturarven som uttrykk for middelalderens storhetstid, evt. som uttrykk for 1500-tallets norske nederlag overfor svensk overmakt som skal formidles, - eller er arkitekt Kjell Lunds stål og glass-monument med en ruin inni en type nyskapt kulturarv som et (nødvendig?) uttrykk for det norske 1990- 
76 tallets ufattelige store oljerikdom?

Mens historievitenskapen preges av en kontinuerlig pågående kritisk diskurs der alle "sannheter" stadig omprøves og imøtegås av nytolking av autentisk kildemateriale, synes det å være slik at den fysiske kulturarven det vi også kan kalle "historien i landskapet" - innpasses i mytiske fortellinger der kritisk diskurs og autentisk kildeverdi i stor grad synes å forsvinne.

Det synes også å være et grunnleggende karakteristikum ved vår samtid at stadig større deler av det fysiske miljøet gjøres til kulturarv, - musealiseres. Vi ser samtidig et stadig større nostalgi-marked på frammarsj innenfor underholdning, folks fritid, hjeminnredning osv.

Hva er det kulturarven gjør i det nåtidige virkelighetsbilde? Er den under kontroll av et profesjonelt fagmiljø, eller er det slik som Hamar-eksemplet antyder, at kulturarven først og fremst er uttrykk for dominerende krefter i den nåtid som til enhver tid organiserer den?

$\AA$ svare på dette er ikke umiddelbart lett. En måte er å gjøre en konkret studie av hvordan kulturarv har oppstått og kanskje også blitt endret over tid. Den vitenskap som beskjeftiger seg med slike spørsmål er museologien - altså vitenskapen om musealiseringen, om hvordan objekter er tillagt så stor verdi at de skal bevares for all framtid. Dette er imidlertid til nå en vitenskap som befinner seg $\mathrm{i}$ fødestua.

Den kulturarv idag som rangerer med aller størst prestisje er innlemmet på UNESCOs World Heritage List. I alt omfatter den nå omkring 500 objekter spredt over hele verden og med "outstanding universal value", slik UNESCO-konvensjonen fra 1972 formulerer det. Av disse verdensarvobjektene er 18 fra de nordiske land. Fra Norge er det valgt ut fire objekter: Urnes stavkirke (verdensarv i 1979), Bryggen i Bergen (1979), Bergstaden Røros (1980) og helleristningene i Alta (1985). De øvrige nordiske land kom inn på verdensarvlisten gjennom 1990-tallet, - Sverige f.eks. i 1991 med Drottningholm som første kulturarv med status som verdensarv.

Bergstaden Røros er for mange kjent gjennom dikteren Johan Falkbergets skildringer. I sine romaner forteller han om menneskenes kamp med naturkreftene og hverandre i gruvebyen langt oppe på høyfjellet innenfor Trondheim, i grensetraktene mot Sverige. Idag feires Røros som kulturarv, ikke minst med grunnlag i den status det gir å stå på verdensarvlisten.

En studie av musealiseringen av Røros viser at vi gjennom 100 år kan følge en kulturarv under kontinuerlig omdanning. Det er på ingen måte slik at det å være kulturarv er noe som tilligger objekter med bestemte egenskaper, og som så er uendret fra det tidspunkt objektet så er "oppdaget".

Umiddelbart er det også tydelig at denne "omdanninga" skjer etter to helt ulike spor: ett om hvilke objekter som kan inngå i kulturarven, og ett om hva en så faktisk gjør med kulturarvobjektene.

Det første sporet handler altså om defineringen av hva som kan inngå i kulturarven på Røros. I utgangspunktet var det kirken og et av bolighusene i byen med mest særpreget arkitektur. Vi er nå ved forrige århundreskifte. Kunstmaleren Harald Sohlberg malte dengang flere motiver på Røros, malerier som allerede i 1909 fant veien til Nasjonalgalleriet i Oslo. I 1920 fikk Norge en lovgivning for bygningsfredning, og den daværende Riksantikvar satte opp lister over bygninger som skulle fredes. På Røros valgte Riksantikvaren 
ut 5 anlegg, temmelig tilfeldig, ettersom ingen av Riksantikvarens folk besøkte Røros. De hadde imidlertid vært i Nasjonalgalleriet, og husrekken på Sohlbergs bilder ble fredet. På Røros hadde en den gang vanskelig med å forstå begrunnelsene for Riksantikvarens utvalg. Eieren av et av husene fikk da også hevet fredningen av huset, og det ble revet for å flyttes til Norsk Folkemuseum i Oslo.

Omkring 1930 var gruvedriften på Røros nede på et minimum og etableringen av et museum ble lansert som en av lokalsamfunnets strategier for å tiltrekke seg oppmerksomhet. En av initiativtakerne her var nettopp forfatteren Johan Falkberget. Han hadde etter utgivelsen i 1923 av "Den fjerde nattevakt" gjennom 1920-tallet plassert seg tydelig i den norske offentligheten med sine historiske romaner. Rørosmuseet åpnet i 1930 i Åsengården, et av anleggene Riksantikvaren hadde fredet. Etter mye fram og tilbake de neste 4-5 år ble det valgt å bygge opp det permanente museet utenfor Bergstaden som et friluftsmuseum (av Skansen-type). Samtidig overtok museet enkelte små stuer i Bergstaden. Museet profilerte seg med Bergmannsdager der Falkbergets romanfigurer "gjenoppstod" og befolket byen.

Det er nå Riksantikvaren igjen vender seg mot Røros. Denne gang ikke som ledd i en stor og skjematisk massefredning slik det skjedde omkring 1920, men som et laboratorium for utprøving av en ny type miljøbevaring. Gamla Stan i Stockholm var ett av forbildene. Nå er det hele gatepartier som skal bevares, og ikke minst motivene som kan knyttes til Falkbergets dikting. I 1939 inviterer Riksantikvaren hele kulturarvsprofesjonen med Fortidsminneforeningen og museumsforbundet til felles årsmøte på Røros. Nå ble tanken fremmet om at turistnæringen skulle redde gruvebyen på fjellet. Så ble det lagt fram forslag om den mest massive bygningsfredning i Norge til da. Innen kort tid var mer enn 80 bygninger i det lille bysenteret fredet.

Det er nå vi kommer til det vi har kalt det andre sporet i omdanninga av kulturarven. En skulle tro at da Riksantikvaren i 1940 endelig fikk gjennomført den omfattende fredningen, så var det fordi disse bygningene skulle bevares for de egenskaper de hadde som kulturarv. Nei, sier Riksantikvarens medarbeider Halvor Vreim. For å vise det "sanne billede av Røros” må bygningene bygges om: paneling, lister og farger må skiftes ut. Startsignalet gikk for en fullstendig omdanning av bygningene.

Hus etter hus ble ombygget - faktisk eksisterer det idag fredede bygg på Røros der bygningen ble fullstendig revet for å bli erstattet av et helt nytt. Gjennom 25 år ble bygninger gitt nye estetiske uttrykk ut fra en innbilt og mytisk oppfatning av hva som var "ekte" Rørosbygninger. Riksantikvarens eget fotoarkiv viser hvordan de systematisk fjernet bygningenes historiske autentisitet, og gjorde så store inngrep at det etterpå ikke er mulig å se hva som er den gamle og fredede kulturarv, og hva som er tilpassede nybygg.

Vernearbeidet på Røros trengte selvsagt penger. Her fikk en ingen god start, ettersom det var ministerpresident Vidkun Quisling som i 1944 i forbindelse med Røros' 300-årsjubileum raust kunne proklamere det første store statstilskuddet på kr. 250.000. Røros hadde en retorisk kraft som allerede hadde vist seg egnet i Riksantikvarens propaganda i 1939. Quisling ville selvsagt også nyttiggjøre seg dette. Langt senere gjør nok de samme vurderinger om propagandaeffekt seg gjeldende, da Røros - på tross av at en da har erkjent 1940- og 50-tallets feilgrep - blir gjort til 
78 norsk pilotprosjekt innenfor det europeiske arkitekturvernåret i 1975. Herfra viste da også veien seg å være kort til en plass på UNESCOs World Heritage List i 1980.

$\mathrm{Vi}$ skal imidlertid vende tilbake til det vi har kalt det første sporet, - hva som er blitt definert som kulturarv. Røros er det sørligste senteret i Norge for den sørsamiske folkegruppa. I sin kamp for egne skoler og derigjennom en akseptering av sin kulturelle egenart, var det den sørsamiske befolkningen som gjennom 1950-tallet faktisk sterkest greide å prege Rørosmuseets utstillinger og aktivitet.

Det som mest særpreget Rørossamfunnet var naturligvis gruvedriften og bearbeidingen av kobbermalmen. De fysiske anleggene knyttet til dette lå imidlertid helt utenfor kulturarv- og bevaringstenkningen. Det passet rett og slett ikke inn i kulturvernprofesjonens estetiserende tenkesett og forestillingen om bonden som nasjonal kulturbærer. Faktisk var det først på 1970- og 80-tallet at det skjedde en omvurdering av dette synet. På Røros fikk det avgjørende betydning at gruvedriften faktisk ble nedlagt for godt i 1977 , etter 333 års drift. Nå kom den politiske og faglige arbeiderbevegelsen på banen og ville ha en framstilling også av gruvearbeideren. Dette skjedde ved bevaring av Olavsgruva som museumsgruve. Rørosmuseet som friluftsmuseum ble nå faktisk nedlagt og de fleste bygningene flyttet tilbake dit de kom fra. På Malmplassen i sentrum av Bergstaden ble det så bygd et nytt museum som en rekonstruksjon på brannruinene av den gamle smeltehytta. Museumsbygget ble åpnet i 1988 .

Røros-eksemplet viser altså ei 100-årig historie om etablering, omdanning og ny etablering av kulturarv i et lite norsk lokalsamfunn. Det er ikke "objektive" og "autentiske" egenskaper ved kulturarvobjektene som har skapt kulturarven. I stedet er den blitt til (og endret) $i$ et spill der ulike aktører har hatt helt påvisbare nåtidige interesser å ivareta på de aktuelle tidspunkt. Tidsperspektivet viser at det da er helt ulike aktører som på ulike tidspunkt har interesse av å skape kulturarv.

Kulturarven er etter dette først og fremst en sosial konstruksjon, en type handlingsrettet kommunikasjon i ei samtid, - ikke uforanderlige og evige kulturverdier. Røros er idag et pittoresk sted som gir assosiasjoner til århundreder med hard kamp for overlevelse. Som historisk dokument over denne tidsepoken er det imidlertid forfalsket. Derimot gir det en sann beretning om historiske, sosiale og kulturelle brytninger i 1900-tallets Norge, - om konstruksjonen av en kulturarv, - ei historie som kanskje kan være like spennende som den om gruvesamfunnet?

En passende epilog kan være fortellingen om huset som først ble fredet på Røros på 1920-tallet, for så å bli revet og sendt til Norsk Folkemuseum i Oslo. Bygningen går under navnet Per Amundsa-gården, og på tomta etter rivingen av huset på Røros kom det umiddelbart en bensinstasjon. Av det en må regne med er økonomiske årsaker, ble bygningen aldri satt opp igjen på folkemuseet, men ble liggende lagret. Men omkring 1970 var bensinstasjonen nedlagt, og Fortidsminneforeningen greidde å gjenreise Per Amundsa-gården på sin gamle plass i Bergstaden. Det er derfor idag et ganske stort paradoks for kulturarven på Røros som verdenskulturminne, at det anlegg som kanskje er best bevart av de gamle hus på Røros, faktisk er så godt bevart fordi det ble flyttet vekk fra byen før antikvarene begynte å omskape kulturarven!

Et annet og kanskje enda større paradoks er så den neste del av historien: på det stedet Per Amundsa-gården skulle vært gjenreist på 
Norsk Folkemuseum, har museet istedet nå

bygd opp en komplett bensinstasjon fra 1920tallet. Selvsagt sponset av et av de store norske oljeselskaper.

\section{Note}

- Texten skrevs för den svenska tidskriften "Tvärsnitt", där den publicerades i nr 1999/2, s. 42-47, i översättning av Martin Kylhammar. 
Nordisk MuseOlogi 200I • I-2, S. 80-92

\section{UR FYRA PLANDOKUMENT}

John Aage Gjestrums 1990-tal dominerades av en febril aktivitet knuten till en rad skilda àtaganden och initiativ. De avspeglas främst i det tiotal 'plandokument' som förtecknas $i$ hans bibliografi. Ur fyra av dem àterges utdrag som kan ge en uppfattning om spännvidden i hans intressen och engagemang. Det första är hämtat ur en studie 1993 på uppdrag av de svenska kommunala museernas samarbetskommitté som fäste uppmärksambet på de svenska lokala museernas undanskymda tillvaro i museilandskapet. John Aage hävdade - vilket onekligen väckte uppseende - dels att den officiellt tillämpade museidefinitionen i Sverige på centrala punkter avvek frän ICOMs, dels att vare sig dessa museers existens eller verksamhet därför överhuvudtaget räknades. Det andra är hämtat ur en förstudie till ett informationscentrum för jugendstaden Alesund, utförd 1995 tillsammans med Marc Maure. Ar 1998 arbetade John Aage med förprojektet till en Antikvarisk Bygningsbank för "Østlandets flatbygd", varur ingressen àterges. Slutligen fäste utredningen 1999 om Kapps mjölkfabrik uppmärksambeten på en föga känd fas av jordbruksnäringens industrialisering.

\section{OM LOKALE/KOMMUNALE MUSEER I DET SVENSKE MUSEUMSBILDET}

Det er pr. idag ganske klart at ingen har presentert noen egentlig oversikt over tallet på museer i Sverige. Ingen kan sees å ha forsøkt engang på å lage en oversikt. Det burde være en viktig utredningsoppgave å få dette gjort.

Det er likevel ikke første gang dette påpekes. I 1986 skriver Margareta Sigurdson om lokalmuseene som 'En träffpunkt i lokalsamhället' i sitt bidrag till antologien Museiperspektiv som Statens kulturråd ga ut:
Bristen på begreppsapparat och terminologi är slående såväl för de lokala museerna som för museer i allmänhet. Överblick över lokala museer saknas. Centrala register över alla dessa museer borde vara något självklart som källa till kunskap i många sammanhang.

Når en 7 år etterpå leser Sigurdsons artikkel er det ihvertfall klart at årsaken til at ingen endring har skjedd i det statlige og offisielle synet på musei-Sverige ikke skyldes at en ikke har kjent svakhetene. Sigurdsons artikkel er klar og tydelig, og et like viktig bidrag i dagens diskusjon som det var i 1986, - men altså bevisst oversett...

Ved å sette sammen tre lett tilgjengelige kilder kan vi imidlertid nærme oss et mer full- 
stendig bilde av musei-Sverige, og kanskje gjøre det vi kan kalle en kvalifisert gjetning i retning av en tallfesting av museene:

1. SCB-statisikken for 1991 omhandler 210 museer, fordelt på 196 institusjoner i 106 kommuner (37\% av svenske kommuner).

2. Boka Museer $i$ Sverige (Bengt Nyström 1990) som omhandler 399 museer i 132 kommuner (46\% av svenska kommuner).

3. Boka Arbetets historia i Sverige (Jan af Geijerstam 1990)som omhandler 385 museer, samlinger og miljöer i 155 kommuner (55\% av svenske kommuner).

Nio museer er nevnt bare i SCB-statistikken, 107 museer er nevnt både i Nyström og Geijerstam. Dette gir en samlet sum på 686 museumstiltak og viser at det $i 194$ svenske kommuner er museumsvirksombet $(68 \%$ av kommunene). Fordelingen på den alminnelig brukte kommuneinndelingen viser følgende. I parentes for sammenligning er tallene fra SCB-statistikken for 1991.

28 glesbygdskommuner:

14 har museer, 50\% (SCB: 7=24\%)

36 landsbygdskommuner

17 har museer, $47 \%$ (SCB: $8=22 \%$ )

16 bruksorter

9 har museer, 56\% (SCB: 1=6\%)

100 normalkommuner

69 har museer, 69\% (SCB: 25=25\%)

38 mellanstora städer

36 har museer, $95 \%$ (SCB: $26=68 \%$ )

26 större städer

26 har museer, $100 \%$ (SCB:26=100\%)

36 förortskommuner

20 har museer, $56 \%$ (SCB: $10=28 \%$ )

3 storstadskommuner

3 har museer, $100 \%$ (SCB: $3=100 \%)$

Et uklart moment i en definering av svenske museer er hembygdsgårdene. Sveriges Hem- bygdsförbund kan ikke gi noen oversikt over hvordan de fordeler seg. Og det dreier seg om mange hundre (800?). I boka Museer i Sverige er det tatt med 10. I 1970 ble 45 tatt med i den landsdekkende museumsbesöksstatistikken. Ved bruk av disse dataene, og enkelte andre kilder som er lett tilgjengelige uten at en her kan gjøre noen grundigere studie av lokalmuseer og hembygdsgårder i de ulike len, kan vi legge til ytterligere 50 museer og 31 kommuner til listen over kommuner med museum. Vi kan da antyde et samlet tall for museer i Sverige på 736.

I den offisielle defineringen av museum i Sverige (Museiföreningen/SCB) legges det inn som kriterium at et museum skal ha minst et årsverk ansatt faglig personale, at det skal være åpent hele året, og dessuten være offentlig. Hva som menes med offentlig går ikke klart fram: offentlig eid?, offentlig finansiert?, ha tilsyn fra offentlig myndighet?, tilgjengelig for offentligheten?. Etter ICOMs museumsdefinisjon er det bare det siste av disse alternativer som er krevet, og en stor gruppe arbeidslivsmuseer og hembygdsgårder vil uten tvil være museer, - hvis de (1) har samlinger, (2) er tilgjengelige for publikum og (3) har en organisasjonsform der formålet er å bevare disse for framtida.

Fordelingen av Geijerstams museer og samlinger på kommuner viste at mens kommunetypen 'bruksorter' bare var representert med ett museum i SCBs statistikk (11\% av kommunene), økte tallet til 9 (56\%) i Geijerstams oversikt. Mens kommuner i gruppene 'glesbygd' og 'landsbygd' nå viser seg å ha lavest museumsdekning (henholdsvis 50\% og 53\%) er det svært sannsynlig at et grundigere arbeid med denne problemstillingen og derigjennom en gjennomgang av hembygdsgårdenes lokalisering og hvilke av dem som kan 
82 regnes som museer, vil føre til at nettopp langt flere av disse kommunene vil vise seg å ha museumsaktivitet.

En konklusion som kan trekkes ut fra dette er at det idag kan sies at det er museumsaktivitet i de aller fleste av Sveriges 284 kommuner (anslagsvis $80 \%$ av kommunene, ca 227 kommuner), og at denne aktiviteten fordeler seg på kanskje mer enn 700 ulike organiserte museumstiltak. I dette ligger også at $90 \%$ av alle svenske medborgere vil finne museumsaktiviteter/tilbud $i$ egen kommune.

Vi har (i ett annat avsnitt) foretatt en vurdering av et sannsynlig samlet besøkstall ved svenske museer, som vi anslår til nesten 50\% høyere enn dagens offisielle, og der dette ikkeregistrerte besöket foregår utenfor storstadsregionene. Fordelingen av et langt større antall museumsinstitusjoner over landet innebærer også at bildet av storstadsdominansen bør tones ned. SCBs statistikk viser at 52 av 210 museer (25\%) ligger i Stockholm, Göteborg, Malmö. Boka Museer $i$ Sverige viser at 88 av 399 (22\%) museer er i disse 3 storstadskommunene. Ettersom museumstiltakene i disse 3 storstadskommunene er godt kjent, er det utover landet vi finner de aller fleste "nye" museene. En beregning gjort ut fra 736 museer viser at av disse er bare $12 \%$ i de 3 storstadskommunene, mens 648 (88\%) befinner seg utenfor. Setter vi dette oppmot SCB-statistikken, viser det at SCB har registrert nær $60 \%$ av museumstiltakene i storstäderna, men under 25\% i landet forøvrig. Museene i de tre storstadskommmunene har istedet for mer enn halvparten av det totale besøkstall (slik SCB-statistikken har registrert), bare ca 1/3 av museumsbesøket i landet.

Videre viser materialet at svært mange av de nye museumstiltakene, - bl.a. i form av arbeidslivsmuseer kommer i kommuner der det tidligere ikke var museer, f.eks. på bruksortene der informasjon om halvparten av museumstiltakene bare finnes i Geijerstams oversikt. For normalkommunene gjelder dette 22 kommuner og for førortskommunene 7 . Også når det gjelder gruppen mellomstore städer (38 kommuner) viser de "nye" tallene sterk økning. Det viktige ved dette er altså ikke bare det at vi viser at flere kommuner har museer, men at det over store deler av Sverige har vokst fram nye typer museer, som $i$ tema, sosial tilhørighet, formidlingsformer og vernefilosofi stair for en fornyelse og nyskapende virksombet innen det svenske museumsbildet.

Et utgangspunkt i dagens samfunnssituatsjon betyr at mange "gamle sannheter" har mistet sin gyldighet. De vekst- og utviklingsprognoser som har preget modernismen, og nådde sin høydepunkt på 1960- og 70-tallet, er nå på 1990-tallet avløst av det mange vil karakterisere som etterindustrielt samfunn, - den postmoderne tidsalder.

Etter en flere hundreårig tidsalder med framskrittsutvikling, er dette antakelig et langt mer dramatisk tidsskille enn vi umiddelbart kan oppfatte. Ikke minst ligger det større humanistiske utfordringer på menneskeheten, som skal å leve med etisk ansvar i ei tid da mennesket har alle muligheter til total ødeleggelse.

Noe av det mest spennende ved å være menneske, er nettopp dette å få være i nåtida, der det fortidige gjennom våre handlinger hele tida er under omskaping. Vi er i en livsform, en kultur, der også museer nå har inngått i flere generasjoner.

Sven B. Ek (i Idéforum museer, 1989) plasserer her lokalmuseene som en front $i$ verksambeten och att det är vid den fronten man arbetar med människorna. Det är där man tar 
tag i problemen och försöker behandla dem $p a$ ett vettigt sätt. Bak fronten, altså de som skal gjøre det virkelige arbeidet på feltet, ser Ek for seg visse støtteorgan, en omdannelse av det hierarkiske bildet som framkommer når det svenske museumsområdet beskrives.

En viktig museumsidé er knyttet til menneskers behov for å kjenne og forstå det sted der de kanskje tilbringer mesteparten av sitt arbeids- og sosiale liv. Bare ved slik forståelse kan enkeltmennesket ta stilling vis-à-vis fortida og de prosesser som har påvirket stedet og menneskene der. Ved å ta posisjon utvikles grunnlag for fellesskap og samhandling, for at menneskene kan bli aktører i verden, ikke bare tilskuere. I dette ligger viktige forutsetninger for våre demokratiske målsettinger.

Hjemstedet i det moderne industrisamfunnet har for mange først og fremst vært oppfattet som et sted stadig å reise fra. I tråd med målsettinger om optimal mobilitet. Det har derfor vært ønsket å knytte "irrasjonelle" følelser, nostalgi og romantikk til hjemstedet, mer enn empiri og faglige begrunnelser.

Det behov menneskene har for historisitet er noe annet enn vitenskapsmenns behov for å 'redde' kunnskapen om fortida. For forskeren er det viktige å finne ut ny kunnskap om historia, å se sammenhenger og oftest vektlegge det som er 'rikshistorisk' interessant. Den samme forskeren vil imidlertid kunne ha liten evne til å forstå at for enkeltmennesket, er det ikke akkumuleringen av ny historisk kunnskap som er verdifull, men etableringen av en historisitet, - av sjøl å være $i$ historia, i en sammenheng mellom det som var, det som er og det som skal bli.

Hvis vi i museene kan forholde oss til fortida som historikere, og være i nåtida som kulturarbeidere, hvilken rolle er vi i når og hvis vi forholder oss til framtida? Jean-Paul Sartre formulerer i sin eksistensialisme et perspektiv som er viktig for vår forståelse av museets og museumsarbeiderens rolle, når vi skal prove å svare på dette.

Menneskets eksistens er ikke statisk, - men blir hele tida til. Individet står i sammenheng med sin fortid, men er ikke absolut determinert av den. Dets tanker, valg og handlinger, - altså dets væren i nåtida, - bestemmes like mye av bevisstheten om framtidige muligheter. "Ifølge Sartre projekterer mennesket hele tiden sine framtidige eksistensmuligheter, ja $i$ en forstand 'er' mennesket disse mulighetene. ...Mennesket er nå ikke lenger det det har vært (i fortiden) og det er nå det det ennå ikke er (blitt i framtiden). Enklere: Mennesket er ikke sin fortid, det er sin mulige framtid" (Espen Schaanning, 1992).

Hva betyr dette for museet? Vi blir nødt til å akseptere museet som et humanistisk prosjekt. For humanisme innebærer vel nettopp denne muligheten, denne friheten til handling. Handlingene her kan være nettopp utvalget av hva fra fortiden som skal gjøres talende i museet, - det kan være å engasjere seg i viktige miljøspørsmål, - det kan være å velge å la alt være eksakt slik det har vært...

Uansett hvilket valg vi tar, så skjer det som et valg, der det eksisterer reelle friheter til å velge annerledes. I dette ligger en etisk utfordring for alle som arbeider med museer. Dette påvirker museets funksjon i nåtida, det påvirker framstillingen av fortida, og det er en del av samfunnets omforming. Kort sagt, museet kan ikke gjemme seg unna sin politiske funksjon.

- Ur en förstudie för Kommunala Museers Samarbetsråd 1993. 


\section{JUGENDSENTERET I Ålesund}

Alle norske byer ble utsatt for storbranner i løpet av siste halvdel av forrige århundre, og med tildels svært omfattende dimensjoner. Størst var bybrannene i Drammen (1870) og Kristiansand (1892). Bybrannen i Ålesund i 1904 ble den aller største i Norgeshistorien. Natt til 23. Januar 1904 ble sentrumsbebyggelsen så godt som totalt utslettet: ca. 800 bygninger brant ned og 12.000 mennesker ble husløse. Bare brannen i Bergen (1916) ble større, men det skyldtes omfanget av verdiene som gikk tapt, mer enn antall hus som brant. Hyppighet og omfang av storbranner avtok fra 1910-åra, noe som i hovedsak skyldtes innføringen av Murtvangloven (1904).

Ålesund kom tidlig inn i en industrialiseringsprosess med modernisering av næringslivet. Byen var preget av omfattende økonomisk ekspansjon basert på fiskeressursene, med stor befolkningsvekst fra slutten av 1860-åra. Byen hadde 1.300 innbyggere da den fikk bystatus i 1848, mens befolkningstallet hadde økt til 12.000 i 1900 . Bebyggelsens struktur ble fortettet og nye områder tatt i bruk. Den nye bebyggelsen som reiste seg på Aspøya var et godt eksempel på det med et mer rettlinjet gatenett enn i det eldre sentrum. En romantisk bypark ble anlagt etter engelsk mønster.

Framvekst av en dynamisk og foretakslystent borgerskap var knyttet til byens økonomiske ekspansjon i århundrets siste halvdel. De store kjøpmennene var mektige; de dominerte byens økonomiske, sosiale og kulturelle liv. De spilte en avgjørende rolle også under byens gjenreisning etter brannen, både økonomisk og organisatorisk, og ikke minst i spørsmålene knyttet til byens utforming.

Valget av jugendstilen som dominerende arkitektonisk formspråk er det nærliggende å se nettopp i sammenheng med denne gruppens smak og behov. Det er vanskelig å tro at bruken av jugendstilen hadde vært så dominerende i byen uten de mektige borgernes samtykke. De sto selv som byggeherrer og oppdragsgivere for arkitektene, for reising av de mest gjennomførte og oppsiktsvekkende jugendbyggene i byen - Rønnebergbua, Stafsethgården, Apotekergården o.a.

Dette er helt i tråd med det som i samme periode skjer i andre jugendbyer i Europa. Et felles kjennetegn ved Art Nouveau/jugendarkitektur internasjonalt er at stilen sjelden ble valgt til utforming av offentlige oppdrag, der i stedet historismen ble foretrukket som formspråk. Det var representanter fra det nye og mektige borgerskapet, vokst fram i kjølvannet av industrialismens ekspansjon, som svært ofte var oppdragsgivere og brukte den nye stilen for å uttrykke sin makt og modernitet. Det er en uløselig del av jugendstil/Art Nouveau som sosialt og kulturelt fenomen i europeisk sammenheng, og gjelder også fullt ut for Ålesund.

Ålesund ble gjenreist i en spesielt betydningsfull historisk periode, - samtidig som Norge oppnår sin nasjonale selvstendighet. Dette ga bybrannen og gjenreisningen en sterk nasjonal symbolsk betydning. Det som skjedde i Ålesund ble en metafor for det som samtidig skjedde med Norge. Det gamle Ålesund brant ned og det nye Ålesund gjenoppstod som fuglen Fønix fra askene, på samme måte som det gamle Norge døde og det nye ble født.

Slutten av det forrige århundret var sterkt preget av arbeidet med å utvikle en norsk nasjonal kultur innenfor alle områder. Det gjaldt bl.a. arkitekturen, der dragestilen var 
svaret for trearkitekturen på behovet for å skape en egen norsk byggeskikk. Det eksisterte også et sterkt ønske om å skape en tilsvarende egen nasjonal arkitektur i stein, med røtter i byggetradisjoner fra den stolte og England/ Normandie-orienterte norske middelalderen. Ålesunds gjenreisning skulle gi mulighetene til å realisere dette programmet i stor skala.

I perioden 1904-07 signerte omkring 50 ulike arkitekter tegninger i Ålesund for nye murhus. Geografisk sett representerte de en stor bredde. De kom fra forskjellige byer i landet. Mange hadde dessuten hatt oppdrag på flere steder i Norge og flere i utlandet. Det var ei gruppe av unge arkitekter; i 1904 var den eldste 55 år, den yngste 25 år og ca. halvparten var yngre enn 35 år. En hovedandel hadde fagutdanning på høyeste nivå med en kombinasjon av norsk basisutdanning og utenlandsk videreutdanning, særlig fra Tyskland.

Verdsettingen av jugendstilen de seinere år har nær sammenheng med det arbeid Unesco har stått i spissen for siden 1985-86, da de første ekspertmøtene i Unesco-regi omkring jugendarkitekturen fant sted. I Unesco-konteksten er så Art Nouveau/jugendstil etablert som et pilotprosjekt for vern av det 20. århundredets arkitektur. Ekspertkomitéen hade sitt første møte i 1987, og da lagt nettopp til Ålesund. Komitéen avslutter sit arbeid i 1994 med Torino-deklarasjonen, som definerer kriterier for hva Art Nouveau-arkitektur er og for vern av denne arkitekturen.

I etableringen av Jugendsenteret i Ålesund er det nødvendig å vektlegge at Ålesunds bygningsmiljø ikke bare representerer et viktig bevaringsprosjekt, men først og fremst er et uttrykk for en spesiell holdning til arkitektur og byforming. Den oppmerksomhet gjenreisningen av Ålesund fikk etter brannen, der en lang rekke av landets fremste arkitekter deltok i utformingen av den nye byen og med jugendstilen som uttrykk, skapte en bybebyggelse av helt unik karakter.

Særpreget for Jugendsenteret vil bli skapt ved det helt spesielle samspillet mellom senteret som et tungt faglig kompetanse- og informasjonssenter og jugendarkitekturens enkeltobjekter og miljøer i Ålesunds bysentrum. Ålesund rommer så mange estetisk spennende objekter, med et i sum så stort samlet volum, at det er dette som bærer prosjektet. Jugendsenteret har imidlertid en nødvendig oppgave i det å skape mening - i å tydeliggjøre og forklare - ikke minst vil institusjonen bli viktig i det å hjelpe den enkelte huseier til å se sin oppgave innenfor den større helhet.

Forståelse blir derfor et viktig stikkord for det som skal være Jugendsenterets endelige produkt. Uten at denne forståelsen blir etablert hos alle aktører $\mathrm{i}$ byen vil det på lang sikt neppe være mulig å bevare jugendarkitekturen i Ålesund. Å formidle en slik forståelse - tydeliggjøre mening - til byens besøkende vil være en annen hovedoppgave, og en virksomhet som vil gi de mange besøkende en større opplevelse. At dette i neste omgang vil virke som en svært positiv faktor på turisme og reiselivsnæring, og derved styrke næringsfunksjonene i bykjernen som helhet, bør det nesten være unødvendig å peke på.

Av de ca. 350 bygningene reist etter brannen innenfor murtvangområdet, er det pr. idag mer enn 300 igjen. Selv om det opprinnelige bybildet er blitt vesentlig endret, er samtidig et omfattende og helt miljø bevart. Jugend- 
86 bebyggelse er etterhvert blitt byens stolthet, statussymbol og et felleseie. Dette kom da også tydelig fram i 1997 da to bygninger tilslutt ble revet, etter en lang og opprivende debatt om saken både lokalt og nasjonalt. Selv om bevaringsinteressene her tapt mot et nybyggingsprosjekt til 60 mill. kr., ble dette også en seier, ettersom utgangspunktet for utbyggerne var at 5 gjenreisningsbygninger skulle rives. Situasjonen som oppstod fokuserte på Ålesunds spesielle kvaliteter, og bevisstheten om dette har fătt sterkt feste både lokalt og nasjonalt. Samtidig viste hendelsene i 1997 at det er et stort behov for informasjon og kunnskapsformidling nettopp av den type Jugendsenteret skal stå for.

Jugendbyens betydning er ikke bare av arkitekturhistorisk karakter. Spørsmålet om estetikkens betydning for en befolknings bo-, arbeids- og oppvekstmiljö, er idag et sentralt debattema. Ålesunds jugendbebyggelse representerer offentlige rom med kunstneriske kvaliteter som har potensiale også til å være en viktig inspirasjonskilde for aktørene i byformingsprosesser i vår egen tid. Det skyldes Ålesunds estetiske og miljømessige kvaliteter: - byen som et definert sted, samlet og tett (kontra byen som åpent og glissent sted) - små dimensjoner og menneskelig skala (kontra undertrykkende og fremmedgjørende arkitektur)

- det uregelmessige, uoversiktelige og derfor spennende (kontra det rettlinjede og monotone)

- formrikdom og variasjon, frodighet i dekor og ornamentik (kontra formspråk kjennetegnet ved asketisme, ensformighet, stimulusfattigdom, karakterløshet)

- håndverk (kontra maskinproduserte og prefabrikerte elementer)
- blandingsfunksjoner med mangfold av hendelser og variert sosial struktur (kontra sonedeling og ensidig funksjonsbruk)

Den faglige virksomheten til Jugendsenteret vil her bli beskrevet i fire hoveddeler:

A: Formidlingstilbud.

Jugendsenteret skal arbeide med informasjon, kunnskapsformidling og holdningsskapende virksomhet rettet mot et bredt publikum, sammensatt av ulike grupper med forskjellige behov og forventninger:

- den spesialiserte bruker som bevisst søker informasjon utfra spesifikt behov om fordypning og oppdatering av kunnskap.

- den interesserte bruker som oppsøker senteret utfra generell interesse for institusjonens arbeidsfelt $\mathrm{og}$ for å få bredere insikt.

- den allmenne bruker som besøker senteret i sin fritid, for å finne generell informasjon, avkobling og opplevelse.

B. Dokumentasjonsvirksomhet.

For Jugendsenteret som kunnskapsinstitusjon innenfor sitt felt vil det bli en viktig oppgave å organisere og studere ulike typer informasjonsmateriale om gjenreisningsbebyggelsen i Ålesund. Dette er en virksomhet som bør bygges på en systematisk, problem- og prosjektorientert strategi. Jugendsenterets dokumentasjonsvirksomhet knyttet til jugendarkitektur vil videre innebære følgende hoveddimensjoner:

- Først knyttet til Ålesund - det spesielle eksempel med den store konsentrasjon av jugendbebyggelse: Hvorfor fikk jugendstilen en slik dominerende plass i byen? Det må gradvis gjøres konkret dokumentasjon om hvert eneste objekt. Det innebærer også dokumentasjon av elementer utover det arkitektoniske 
ytre, som innredning, møblering og dekor.

- Deretter knyttet til det nasjonale nivå med oppbygging av kunnskap om jugendarkitektur $\mathrm{i}$ andre norske byer. Ved at en på et sted får en samlet dokumentasjon vil ny kunnskap kunne etableres, bl.a. i de ulike arkitekters produksjon.

- Den tredje, men ikke minst viktige dimensjon er knyttet til det internasjonale niva: Jugendsenteret vil som nasjonal institusjon presentere norsk jugendarkitektur internasjonalt - og samtidig bygge opp en så omfattende dokumentasjon som mulig om Art Nouveau/ jugendstil $\mathrm{i}$ andre land. Internett-samarbeid med sentrale europeiske jugendbyer skal utgjøre et viktig element i sammenstillingen og tilgjengliggøringen av denne dokumentasjon.

C. Kompetanseoppbygging murhåndverk. Det er idag et stort misforhold mellom den kunnskap som er utviklet i Norge omkring bygging i tre og bygging i mur. Dette henger sammen med hvordan norsk arkitektur tradisjonelt har vært dominert av tre som byggemateriale. I eldre tid ble stein og mur bare brukt i helt spesielle sammanhenger, og da først og fremst i kirker, militære anlegg og andre offentlige bygninger.

Opp mot et nytt århundreskifte er det imidlertid nå tydelig at en stadig større del av arkitekturen som inngår i verneplaner og skal sikres for framtida, er bygget i mur - bl.a. nettopp fordi bebyggelsen er i bymiljøer der Ålesund-brannen i 1904 ga mer restriktive påbud om bruk av mur.

For norsk trebebyggelse er det i lang tid arbeidet aktivt med forskning og kunnskapsformidling omkring alle sider ved både håndverksteknikker, materialbruk og konserveringsprinsipper. Det betyr at det finnes både godt utviklede vitenskapelige fagmiljøer, or- ganiserte opplæringstiltak og utøvere av praktiske håndverksferdigheter.

Ålesunds store kvaliteter som murhusbebyggelse gjør det attraktivt å legge aktiviteter på nasjonalt plan rettet mot kompetanseoppbygging innenfor murhåndverk hit.

D. Internasjonalt nettverk.

Art Nouveau/jugendstil-bevegelsen var i sin natur et europeiske fenomen. Et hovedkjennetegn var en aktiv og omfattende spredning av idéer og produkter på tvers av landegrensene, og av enkelte byers dominerende plass $\mathrm{i}$ bevegelsen.

Internasjonalt har stilen lenge vært glemt og misforstått, og byggene utsatt for forsømmelse og riving. Men nå er jugendstilen blitt objekt for en omfattende interesse som aktualiserer et behov for kontakt og samarbeid over landegrensene.

For Ålesund vil kontakt og samarbeid med fagmiljøer i andre land bety mulighet til økt forståelse av byens egenart som jugendby. Samtidig vil fokus på Ålesund-bebyggelsen representere et nytt perspektiv i Art Nouveau/ jugendstil-forskningen internasjonalt, - en forskning som hittil har lagt hovedvekt på unike og isolerte verk fra de mest kjente arkitektene.

Kontakt og samarbeid med de europeiske jugendbyene vil i tillegg ha konsekvenser på andre felt, f.eks. som virkemiddel for profilering av Ålesund i det internasjonale reiselivsmarkedet. Dette samarbeidet vil dessuten kunne foregå utfra bredere perspektiver, av både kulturell og økonomisk karakter, som ledd i de strategier som idag kjennetegner den europeiske integrasjonsprosessen.

- Ur Jugendsenteret - en nasjonal institusjon. Ved J.A.G. og Marc Maure. Ålesund 1997. 


\section{EN ANTIKVARISK}

\section{BYGNINGSBANK}

Hvis du idag anskaffer en bil fra 1951, vil du gjøre dette uten noe ubehag knyttet til mulighetene for å skaffe nødvendige deler til motor, dekk, bremser osv. Ubehaget er evt. at en slik bil er forholdsvis dyr å anskaffe, og kanskje heller ikke så komfortabel å kjøre. Men opp gjennom årene har det skjedd en tilpasning mellom et spesielt marked og dets behov for spesielle produkter. Derfor er det en ganske kurant sak å eie en veteranbil, - og dessuten ganske morsomt.

Av grunner som ikke kan forklares her, har det ikke skjedd den samme grad av tilpasning mellom tilbud og etterspørsel når det gjelder det behov eiere av eldre hus har for produkter til istandsetting, vedlikehold og restaurering. Mens ingen en gang ville tenke tanken på å sette en ny Toyota-skjerm på en 1930modell A-Ford, skjer dette hele tida på gamle ærverdige hus omkring oss. Originale, profilerte paneler blir erstattet av "brutal" tømmermannspanel med harde kanter, og fint inndelte og omrammede vinduer i sveitser- eller jugendstil blir erstattet med husmorsvinduenes gapende hull i fasaden.

Selv på biler som sannsynligvis skal skrotes om bare 7-8 år passer eierne karosseriets overflate mot enhver minste rip eller bulk. $\mathrm{Og}$ dette er en investering som innen kort tid skal nedskrives til 0. Et hus derimot representerer kanskje bortimot en million i verdi og skal stå i landskapet i generasjoner. Det ser ikke ut til å hindre eierne fra om og om igjen å velge de simpleste løsninger. Mens en ikke vil tenke tanken på å kjøre bil med en upassende skjerm, kanskje kr. 3000,- billigere enn "originalen", er en overlykkelig om en kan spare en tusenlapp på å sette et vindu inn i huset som "nesten" passer vegåpningen etter det gamle. En fyller bare i $20 \mathrm{~cm}$ under og tar ut $20 \mathrm{~cm}$ breiere åpning, og vips...(!)

Virkelighetsbeskrivelsen ovenfor kan sees som satt på spissen. Samtidig peker den mot noe av det som er hovedproblemstillingen for etableringen av en Antikvarisk bygningsbank for flatbygdsområdet på Østlandet: det er behov for en aktiv synliggjøring både av verdiene som ligger i riktig håndtering av den eldre bygningsmasse, og ikke minst er det behov for aktive tiltak som kan skape kontakt mellom et mulig tilbud og et mulig marked for produkter og tjenester.

Denne utredningen viser at det finnes et stort tilbud fra en lang rekke leverandører av tjenester. I regionen vi retter oss mot er det antakeligvis også mer enn 100.000 huseiere med bygninger som er eldre enn 100 år - og et langt større tall hvis vi også inkluderer en vesentlig del av bygningene bygd i tiårene oppover på 1900-tallet, bygninger som også er i stor fare for å bli maltraktert.

Bygningsmiljøet i landsbygd, tettesteder og byer skal i prinsippet ivaretas gjennom et godt utbygd regelverk i plan- og bygningslov, forvaltet av den enkelte kommunes bygningsetat. Praksis viser likevel at den formelle apparat synes å ha bare svært begrenset innflytelse over hva som skjer med den eksisterende bebyggelse. Den enkelte huseier synes å være fanget i de store byggevarehusenes standardiserte og storindustribaserte byggevareutvalg, tilpasset dagens moter innenfor nybygging. Dette fører til at mange føler seg maktesløse overfor oppgaven knyttet til å istandsette et eldre hus, og istedet river det for å bygge nytt. Eller at de forsøker å få det gamle huset til å "bli nytt" ved bruk av nye bygningsmaterialer. 
Mulighetene som ligger i gjenbruk av gamle bygningsmaterialer - som fortsatt vil være både funksjonsdyktige og estetisk overlegne - blir ikke synlige i dagens situasjon. Alle de mindre spesialleverandørene av produkter og tjenester er heller ikke synlige fordi de hver for seg er ganske små i markedet.

Agenda 21 er tittelen på sluttdokumentet fra FNs toppmøte om miljø og utvikling i Rio 1992. Dokumentet peker ut veier framover inn i det 21. århundre med løsningen på verdens miljøproblemer. Norge har undertegnet dokumentet. Et hovedperspektiv her er at det er behov for radikale endringer i de rike lands forbruksmønster dersom miljøproblemene skal kunne håndteres. I motsetning til de fleste slike avtaler med nasjonalstatene som aktører, vektlegger Agenda 21 betydningen av handling også på de lokale/kommunale nivåer i forvaltningen. Dokumentet peker faktisk på at det er på dette nivået en har kunne se konkrete resultater. Slagordet "tenke globalt, handle lokalt" poengteres, og: "Fordi de står menneskene nærmest, spiller lokale myndigheter en avgjørende rolle når det gjelder å opplyse, mobilisere og fange opp befolkningens ønsker $\mathrm{i}$ arbeidet med å fremme en bærekraftig utvikling", sies det i avsnitt 28 i Agenda 21. Og videre:

Alle lokale myndigheter bør gå inn i en dialog med innbyggerne, lokale organisasjoner og private bedrifter og vedta en "Lokal Agenda 21". Gjennom samråd med sikte på å skape konsensus, vil de lokale myndighetene lære av befolkningen og av de lokale frivillige organisasjoner, beboergrupper, bedrifter og fagforeninger og tillegne seg den kunnskapen som trengs for å utvikle best mulige strategier. Samrådsprosessen bør øke husholdningenes bevissthet om spørsmål som angår bærekraftig utvikling.
Mens mye av aktiviteten ikke minst på bygningsfeltet de siste to-tre tiår har vært preget av teknokratiske og kortsiktige perspektiv peker Lokal Agenda 21 på nødvendigheten av tidsperspektiver på 50-100 år - til nå nærmest ukjent i alminnelig lokal planlegging. En peker også på nødvendigheten av å knytte sammen miljøtenkningen med tenkning omkring livskvalitet. I dette perspektivet er den historiske bygningsarven nettopp én av faktorene som gjennom å gi historisk dybde i menneskenes daglige livsrom, nettopp vil kunne øke folks livskvalitet.

Et av de politiske konkretiseringer av målsettingene fra Rio-konferensen i Norge er St.meld. 58 Miljøvernpolitikk for en barekraftig utvikling (1996-97). Et av områdene som umiddelbart kommer i søkelyset når en skal nå lenger i utviklingen av et økologisk bærekraftig samfunn er bruk og ombruk av eldre bygninger, bygningsdeler og materialer.

Gjennom nye byggherreforskrifter er det kommet helt nye krav til byggeherrer og entreprenører som gjør oppføring, rehabilitering eller riving av bygninger. Byggherren er pålagt å utarbeide en plan for avfallshåndtering, og i miljøvernperspektiv er det en overordnet oppgave å minske avfallsmengden fra bygg/ anleggsvirksomhet. Faktisk representerer detta avfallet i Norge 1,2 mill. tonn pr. år, like mye som den samlede avfallsmengde fra norske husholdninger. Beregninger som er gjort viser at bare ca. $8 \%$ av bygningsavfallet går til ombruk og gjenvinning i en eller annan form.

- Ur forprosjekt 1998. 


\section{Fra "Syltet" MELK TIL VIKING-MELK}

Historien om Kapp Melkefabrikk fra de første spadestikk høsten 1889 og fram til idag 110 år etterpå, er selvsagt ei historie om produksjon av melkeprodukter, tekniske produksjonsmåter og framveksten av en industriog arbeiderkultur $\mathrm{i}$ en kommune som til da hadde vært preget av å være et bondesamfunn. Samtidig er historien om Kapp Melkefabrikk og dens Viking melk ei historie som inkluderer en lang rekke viktige begivenheter, personer og årstall. Og ikke minst er denne historien ei fortelling om samspillet mellom et lite samfunn på Toten och en stor verden utenfor.

Kondensert melk er et produkt som først så dagens lys i USA på 1850-tallet. Amerikaneren Gail Borden fann ut at han kunne dampe in melka til bare $25 \%$ av det opprinnelige volum. Ved å koke i en lufttom kjele, altså under vakum, kunne innkokingen skje ved bare 30 graders varme. Den innkokte melka ble så tappet på blikkbokser som ble loddet igjen. For at melka skulle holde seg ble den imidlertid tilsatt sukker. Melka ble altså syltet og hermetisert. Kondensert melk ble et populært produkt. Ikke minst fordi det i siste del av 1800-tallet kom en voldsom økning i trafikken med handelsskip og det tidligere ikke hadde vært mulig å oppbevare melk over lang tid. På samme tid er det i ferd med å vokse fram store markeder for næringsmidler i stadig voksende storbyer.

I 1867 ble den første europeiske "syltede" melk produsert i Sveits, og i 1874 etablerte dansken Jess Thomsen den første norske fabrikken for sukret kondensert melk på Ha- mar. Thomsen hadde vært i Sveits og lært metodene. Geografisk sett er vi nå altså i Mjøsbygdene, og i ferd med å nærme oss Kapp.

Fabrikken på Hamar kom i produksjon i 1875, og kunne etter få års drift ta imot to mill. kg melk. I 1879 ble fabrikken overtatt av ei britisk/svensk investorgruppe og produksjonen ble utvidet til 7-8 mill. kilo årlig. Snart trengtes mer melk enn Hedmarksbøndene kunne produsere, og fabrikken kastet sine øyne på Toten.

Historia om hva som skjedde da oppkjøperne fra den engelske melkefabrikken i 1888 kom till Toten, er godt kjent. Storbonden Johannes Sund hadde invitert bygdas fremste menn til å møte oppkjøperne, og det ble servert velsmakende melkepunsj. Overrettssakfører Ulrik Graff var tilstede og noterte seg avtalene de kom fram til. Og etterhvert som melkepunsjen virket, ble forhandlingsklimaet bedre og bedre. Neste dag da Graff presenterte avtalen for oppkjøperne, hadde melkepunsjens effekt gått over. Graff mente de hadde engasjert ham til å være deres agent, slik at han skulle ha 1 øre pr. liter av melken han skaffet fabrikken. Dette ble avvist, - nei fra Hamar ville de gjøre avtaler med hver bonde og ikke gjennom noen mellommann.

Dette gjorde Graff sint, - ville ikke fabrikken kjøpe av ham, skulle de ikke få kjøpt noen melk på Toten i det hele tatt. Graff satte seg umiddelbart i kontakt med meieribestyrerne og bøndene som dengang foredlet melka i 12 små bygdemeierier spredt over hele Toten. Han sikret seg kjøpsavtaler på all melk ett år framover. Han sikret seg også alle ledige strandtomter runt Smørvika på samme måten. De som ønsket å kjøpe melk på Toten og frakte den på Mjøsa fra Kapp, måtte gjøre avtale med Graff. Men det som var en strategi for å få oppkjøperne fra Hamar til å gjen- 
nomføre sin opprinnelige tanke og samtidig sikre Graff en god profitt som mellommann, viste seg å slå feil. Hamarsingene og engelskmennene sa rett og slett nei, og fant det mer interessant å satse på bøndene i Østfold ved å bygge en ny stor fabrikk i Sandesund ved Sarpsborg.

Graff som hadde forespeilet totenbøndene store salgsinntekter av melkeproduksjonen, havnet nå i ei knipe. Eneste mulige løsning måtte rett og slett bli å sjøl starte opp en egen fabrikk. Graff satte igang arbeidet med å skaffe kapital. Det som imidlertid reddet ham, var den unge legen og mykologiforskeren Olav Johan Olsen, forresten også han fra Hamar, som satt i Kristiania og forsket på gjærsopper i ost. Nærmest ved et uhell fant han metoden for hvordan det kunne være mulig å konservere melk uten å tilsette sukker. Metoden var klar i 1889, samtidig med att Graff hadde startet organiseringen av sitt forretningsprosjekt. I oktober 1889 ble de endelige avtaler gjort mellom Graff og Olsen, - kong Oscar II tegnet seg for 10.000 kroner i aksjekapital, - de rikeste forrettningsfolkene $i$ landet fulgte etter og byggingen av fabrikken på Kapp startet. Etter problemer i driftsstarten var produksjonen endelig igang 7. februar 1891. Forsinkelsene tæret imidlertid på aksjekapitalen og etter 2 års drift var fabrikken i konkurs.

Produktet, usukret kondensert melk, var imidlertid godt. Og da driften startet opp igjen med ny aksjekapital i mars 1894 , kunne Olav Johan Olsen presentere melkeboksen med ny etikett: "Viking Melk". Året før hadde nemlig Magnus Andersen gjenomført ei vågal sjøreise tvers over Atlanterhavet i en nybygget kopi av Gokstadskipet. I alt 12 mann seilte $\mathrm{i}$ vikingeskipet over til verdensutstillingen i Chicago, og ombord hadde de selvsagt usukret kondensert melk fra Kapp.
Den nye etiketten for Viking-melk var laget av datidas kjente illustratører Andreas Bloch og Olaf Krohn.

Et varemerke var født. Viking Melk hadde ikke bare ett godt navn i 1890-tallets nasjonale bølge, men var også et godt produkt. Dette går ikke minst fram av det faktum at Viking Melk fortsatt produseres i Norge, 108 år etter de første boksene ble tappet på Kapp. Dette gjør Viking Melk til det eldste serieproduserte næringsmiddelet i Norge. Idag produseres den i Levanger av en årlig melkemengde på omlag 250.000 kilo.

Det ble en hovedsak å knytte Viking-melken til århundreskiftets store nasjonale helter som Fritjof Nansen og Roald Amundsen og til deres oppdagelsesreiser. Det var markedsføring som også var effektiv i de internasjonale markeder. Samtidig ble også Viking-melken kjent hos konkurrentene. En av disse var Nestlé-selskapet i Sveits. Deres argeste konkurrent Anglo-Swiss hadde fabrikker i flere land, og hadde i 1896 kjøpt fabrikkene på Hamar og Sandesund. Nå ønsket Nestlé å få fotfeste utenfor Sveits og kastet sine øyne på fabrikken på vestsida av Mjøsa. Etter forhandlinger høsten 1897 kunne så Nestlé overta sin første fabrikk utenfor Sveits. De betalte 720.000 kroner for alle aksjer i Kapp-fabrikken. For retten til å utnytte hans metode fikk Olav Johan Jonsson stilling som direktør, og økonomiske vilkår ellers som sikret ham økonomisk i si levetid foruten full frihet til å fortsette sitt vitenskapelige arbeid. Ikke dårlig for en 37-åring!

Nestlé sendte sine folk oppover fra Sveits og startet en vesentlig utbygging av fabrikken. De bygde også produksjonslokaler for sukkertilsatt melk. Produksjonen fra sept. 1900-sept. 1901 var 1,6 mill. kilo sukret melk og $800.000 \mathrm{~kg}$ usukret melk. I 1905 gikk 
92 Anglo-Swiss og Nestlé sammen. Istedet for å konkurrere med hverandre om pris og markeder, kunne de nå nyde godt av økende etterspørsel og store markedsandeler over hele verden.

Dette betød økt satsing på Kapp. Fabrikken var den største fabrikken selskapet hadde i Norge. Det ble utvidelser, og i 1910-1912 ble det gjort en stor utbygging. Det ble bygd et stort verksted for boksproduksjon, også beregnet på leveringer til de andre fabrikkene. Det ble bygd nytt pakkeri og det ble bygd en stor kontorbygning for selskapets sentrale bokføring. Bygget inneholdt også laboratorium for dr Sopp, lenge kaldt Sopp-Olsen, og som nå siden 1907 etter Bjørnstjerne Bjørnsons råd rett og slett tok Sopp till familienavn.

Fabrikken var nå inne i si glanstid. Arbeidsstyrken nådde 280 på det meste. Fabrikken kunne ta imot 60.000 liter melk om dagen fra hele Toten, men ved båttransport også fra Ringsaker og bygdene nord for Gjøvik. I 1915 tok Kapp imot 13 mill. kilo melk som den største melkekondenseringsfabrikk i landet.

"Kokeriet" skapte gode salgsinntekter for leverandørene og ringvirkninger ellers i lokalsamfunnene. Ikke minst innen fjøsstell og renslighet satte melkefabrikken nye standarder. Og for $\varnothing$. Toten som vertskommune utgjorde skatteinntektene fra fabrikken og arbeiderne i flere år omlag 25\% av kommunens samlede skatteinntekt.

Men toppen var nådd. Først kom det vansker skapte av verdenskrigen, og deretter av den generelle nedgangstid som virket sterkt inn på både markedet og kostnadene. Nestlé fant ut at Kappfabrikken hadde de høyeste kostnadene, og brukte nå nedleggelse av Kappfabrikken som trussel og våpen overfor det de oppfattet som urimelig høye lønnskrav fra arbeidernes organisasjoner.
"Nedleggelsen av fabrikken på Kapp skal også tjene til å vise funksjonærene og arbeiderne ved våre øvrige fabrikker at vi mener alvor med kravet om reduksjon av det altfor høye lønnsnivået. Vårt forslag om et nedslag på 25\% skal opprettholdes..." skriver Gustave Huguenin, konsernsjefens høyre hånd $\mathrm{i}$ Vevey (Sveits) i juli 1927. Da hadde allerede bemanningen på Kapp blitt redusert fra 240 til 100 gjennom de to foregående år.

Arbeiderne på fabrikken hadde dannet fagorganisasjon i 1912, og markert Kapp som bygdas "røde sentrum". I oppgangstider var foreningen nyttig, nå hadde en ikke noe å stille opp. Varaordfører C:A. Madsen uttaler i Oppland Arbeiderblad: "At fabrikken blir nedlagt er en ulykke både for bygden og den gamle, solide arbeidstok på Kap”. Og ulykke ble det - etterhvert som skatteinntektene uteble, og kommunen også måtte svare for lånegarantier gitt til arbeidernes boligfinansiering, gikk $\varnothing$. Toten kommune rett og slett konkurs. Kommunen måtte under administrasjon som vedvarte helt til midten av 1930-tallet.

Produksjonen av Vikingmelk ble innstilt 1 . juli 1928. En del av arbeiderne fikk arbeid på Hamar-fabrikken. Noen få kunne fortsette på Kapp ved laboratoriet og med produksjon av emmenthalerost, tørrmelk og barnemelk. Melkerasjonaliseringen under krigen satte imidlertid en stopper også for dette, slik at høsten 1942 opphørte den siste produksjon i Nestlés regi.

- Ur Kapp Melkefabrikk Utviklingsplan 1999-2005. 


\section{Jeg Husker DEg, John Aage ...}

Siste gang jeg så deg, John Aage, var den 28. mars i fjor. Det var sent på kvelden og vi satt på kaféen til det tidligere Lenin Museum i byen Krasnojarsk i det indre av Sibir. Vår venn Vladimir, leder for organisasjonen Memorial, hadde lenge fortalt oss om Sibirs tragiske fortid, og om sitt trøstesløse arbeid med å redde minnene fra GULAG-øyriket fra glemselen, som hadde hatt så stor utstrekning her i regionen. Jeg så på deg, og jeg skjønte at du følte som meg, at meningen med det internasjonale samarbeidet nå hadde fătt en ny dimensjon, at det var en forpliktelse å engasjere seg og hjelpe til med dokumentasjonen av de mørke sidene ved det 20. århundrets historie.

Dagen etter tok jeg flyet tilbake til Oslo. Du skulle komme etter ett par uker senere. Den 6. april, kl. 6 om morgenen, ringte telefonen fra Krasnojarsk, og de sa at du var død, at det hadde skjedd brått, for bare en time siden ... Våre venner fra Krasnojarsk fortalte meg senere at du kvelden før hadde hatt en lang samtale med en mann derfra som under krigen, som barn, hadde levd sammen med sin mor i en tysk arbeidsleir ved Kirkenes. De sa at du hadde kommet fra dette møtet meget berørt, og at det kanskje var det som hadde "knust ditt hjerte" ...

Jeg husker godt første gang jeg så deg, John Aage. Det var under Museumsforbundets årsmøte på Røros i 1977. Som følge av innføring av tilskuddsordningen et stort vendepunkt for de norske museene - hadde en ny generasjon av konservatorer her gjort sin entré på museumsscenen. Du var da 24 år gammel og nylig ansatt som bestyrer av Toten Museum. Jeg kjente deg ikke, men jeg ble oppmerksom på deg. Du sto midt i en gruppe, og argumenterte intenst og gestikulerende, med et engasjement og en energi som du beholdt helt til slutt. Dette bildet er for meg blitt stående som symbol på fornyelsen som skulle prege det norske museumssystemet $\mathrm{i}$ de påfølgende årene. En fornyelse der du spilte en aktiv rolle, både som ideolog, praktiker og debattant.

Du hadde begynt å arbeide på Toten Museum lenge før du ble ansatt som bestyrer. Du var fra Toten og allerede i 1960-årene, hadde du som barn, skaffet deg variert praksis fra museumsarbeid. Fra begynnelsen av 1980-tallet omdannet du det 
94 gamle museet på Toten til en institusjon som etterhvert fikk internasjonalt ry for sitt banebrytende arbeid: Toten Økomuseum. Her var museumsarbeidet blitt et aktivt bindeledd mellom fortid, nåtid og framtid. Gjennom systematisk dokumentasjon og formidling ble lokalbefolkningen trukket inn som deltaker.

Jeg husker et seminar på Toten i 1987, da du med stolthet presenterte museet til Hugues de Varine, den store pionier av de franske "écomuseene". Jeg husker også den energi du la inn i opprettelse og drift av den Norske Gruppe av Økomuseer, som samlet kolleger som delte vårt syn, og som spilte en sentral rolle som forum og nettverk for utvikling av nye museumsmodeller.

Samtidig begynte du å engasjere deg i det internasjonale museumssamarbeidet. Jeg husker deg fra en mottakelse i en park i Greenwich ved London, under ICOMs Generalkonferanse i 1983, der du snakket med stor intensitet med tolken til den kinesiske delegasjonen. Det var første gang du deltok på en internasjonal konferanse, som nyvalgt medlem i Norsk-ICOMs styre. Dette var begynnelsen på et mangfoldig og fruktbart internasjonalt engasjement, der du spilte aktive roller somt blant annet styremedlem i ICOMs internasjonale komité, ICR Regional Museums i 1980årene og ICOFOM Museology i 1990-årene.

Jeg husker deg som skribent og redaktør, en aktivitet du hadde spesielt stort talent for, først foran en enorm datamaskin som fylte det meste av ditt arbeidsrom, og som etterhvert ble erstattet av et imponerende antall Mac'er av forskjellige modeller. Jeg husker ditt arbeid med Museumsnytt i 1980-årene, som ble omdannet til et innsiktsfylt informasjons- og debattorgan. I 1990-årene ble Nordisk Museologi ditt hjertebarn; du investerte på mange forskjellige måter mye engasjement og kreativitet i dette tidsskriftet, et verk som du med rette var spesielt stolt av.

I 1991 forlot du Toten Økomuseum for å arbeide med forskjellige prosjekter i Norge og i utlandet. Du begynte å studere museologi som doktorgradstudent ved universitetet i Umeå. Din doktoravhandling, som bygde på en original studie av utviklingen av kulturverntanken på Røros, ble dessverre aldrig ferdig; til det hadde du engasjert deg for sterkt i for mye.

Du ble samtidig spesialist i museumsplanlegging på frilansbasis. Det var ikke få prosjekter i Norge i 1990-årene, både store og små, som dro stor nytte av dine faglige og strategiske evner. Denne virksomheten kulminerte med åpning av Ivar Aasen-tunet/Nynorsk kultursentrum sommeren 2000, realisert i samarbeid med den store arkitekt Sverre Fehn. 
Jeg har mange minner, John Aage, fra vårt samarbeid over en lang periode. Det fineste er kanskje det jeg opplevde under herlige høst-dager i 2000, da vi var sammen med en gruppe kinesere som var på besøk i Norge. Det var dine samarbeidspartnere - både museumsfolk, politikere og vanlige bønder - fra Guizhou-provinsen i Kina der du hadde arbeidet med utvikling av økomuseer. Dette var et viktig øyeblikk for deg, en feiring av flere års arbeid med et prosjekt som kan betraktes som modell for spesielt vellykket utviklingsarbeid. Og det som gjorde dette prosjektet spesielt vellykket var at du hadde, noe som var så tydelig å se da du var sammen med dine kinesiske venner, satt menneskene i sentrum.

For deg, John Aage, var den menneskelige dimensjonen selve meningen med museumsarbeidet. Høyt profesjonelt nivå var alltid kombinert med stor generøsitet. Du ville gi en "gave" til levende mennesker, gi dem det beste du - som museumsmann - kunne, med den hensikt å få dem til å vokse.

Dette er et viktig budskap i en tid der vi - museumsfolk - blir stadig mer utsatt for en ideologi som vil få oss til å omdanne vår faglige innsikt til en "vare" som skal selges til kunder.

Marc Maure 


\section{John Aage Gjestrums TRYCKTA SKRIFTER}

Per-Uno Agren

Bibliografin är sammanställd på grundval av listor ställda till förfogande av John Aage Gjestrums hustru Elisabeth Nordengen samt en publikationslista som John Aage själv upprättat 1992. Titlarna är ordnade i huvudgrupperna Bøker, Artikler (med undergrupperna Arboka TOTN, Museumsnytt, Nordisk Museologi och Øvrige artikler), Plandokumenter och Foredrag. Inom varje grupp redovisas titlarna kronologiskt.

\section{BøKER}

1984

Gards-og slektshistorie. En studie av 170 bokmeldinger av gards-og slektshistoriske bygdebøker i tidsskriftet Heimen. Gjøvik. Totens Bokhandel.

\section{5}

Muntlig historie i det museale arbeidsfelt. Telemark distriktshøgskole, Kulturarbeiderstudiet. Ved katalog til Toten Museums lydbåndarkiv, båndsidene 1-100. $50 \mathrm{~s}$.

1987

Landskapet på vestsida av Mjosa. 1837-1987. Jubileumsbok utgitt av Gjensidige Vestoppland. Gjøvik.

Økomuseumsboka - identitet, økologi, deltakelse. Red. J.A.G. og Marc Maure, Norsk ICOM. Tromsø. 1991

Visjon og virke. Johannes Sivesind 70 år. Red. J.A.G. Utkom som Årboka TOTN 1991.

\section{Artikle R}

1. Årboka TOTN (redaktør 1978-1991) 1976

"Sæterhus på Toten", s. 186-200.

1977

"Ta vare på gamle fotografier", s. 296-300.

1978

"Hågår gård til Toten museum", s. 362-366.

1979

"Jernbanebebyggelse og stasjonsbyer. Søkelys på århundreskiftets arkitektur og lokalhistorie", s. 14-21.

"Et virkelig godt bilde skal tåle å henge opp ned", s. 22-29. Intervju med Ingvar Heggsum.

"Gjøa-bua". (Lokalt sagnstoff), s. 30-32.

"Ach, wie fluctig, ach, wie wichtig. Hofforglet på

Norsk Folkemuseum klinger igjen", s. 55-57.

"Det eldste Totenpostkort", s. 77.

1980

"Skoleminner fra 1880-åra: 100-årige Marie Stangjordet forteller", s. 30-33. 
"Søkelys på arbeiderkulturen. Arbeiderbilder fra Raufoss", s. 78-87.

"Verneprosjektet Ytre Amunddalen", s. 132-137.

\section{1}

"Kulturlandskap, museum og bygningsvern", s. 7-13.

"Stenberg - museum i 50 år", s. 38-49.

"Bygningen", s.118-132.

1982

"Gjenstandene i museumsarbeidet: Skal vi samle på kunst, antikviteter eller skrap?”, s. 48-55.

\section{3}

"Tolv totninger forteller", s. 6-7.

\section{4}

"Totenkniven - husflid, småindustri og kunsthåndverk", s. 6-46.

"Turist på Hadeland og Toten i 1784", s. 101-110.

"Hoff Arbeidersamfunn", s. 114-117.

\section{5}

"1900-tallet - snart forrige århundre. Økomuseet

- et bindeledd mellom fortid, nåtid og framtid", s. $6-15$.

"Fra 9. mai til 9. juni. Billedserie fra HS-gruppa på

Raufoss", s. 30-43.

\section{6}

"Skreia jernbanestasjon - en perle som jernbanehistorie og miljø”, s. 6-31.

"Taarene rand ved efter kindene paa hannem. Om husmann og bonde på Toten i 1712", s. 63-64.

"Tre husmannskontrakter fra 1800-tallet", s. 65-71.

1987

"Innledning til Jens Raabe: En storbygd", s. 6-11.

\section{8}

"Hovedbygningen fra Raufoss gård blir en del av økomuseet", s. 86-95.

"Ny kilde oppdaget: Da fyrstikkfabrikken ble bygget”, s. 107-117.

"Ingen lek, men arbeid og slit! Industrielt barnearbeid på Raufoss 1875-1895”, s. 118-126. Denne artikkelen er tidligere trykt i Ophedia 1982.
"Petra Jensen bodde "i bolin", s. 127-130.

1990

"Økomuseet - for lokalsamfunnet i verden", s. 6-15.

"Einar Hermanrud (1893-1981) forteller historie",

$$
\text { s. } 76-105 \text {. }
$$

1991

"Visjon og virke - Johannes Sivesind 70 år". (J.A.G. red.)

\section{Museumsnytt (redaktør 1989-1991)}

\section{2}

"Opplandsmuseene mot år 2000: om en start på arbeidet med 1900-tall og samtidsdokumentasjon i Oppland." Nr 3, s. 14-17.

1983

"Regionmuseet: Et bærende element i norsk museumsvesen?" $\mathrm{Nr} 3$, s. 11-14.

1984

"Seminaret: økologi og identitet - økomuseumstanken har slått rot i Norge”. Nr 2.

1985

"Fra vikingmelk til industrikultursenter". $\mathrm{Nr} 1$.

"Museene og industrisamfunnet", fra en rapport ved Roy Høibo, Jone Johnsen og Torleif Lindtveit. (Sammenfatning ved J.A.G.) Nr 2.

"Museer også for 2000-tallets mennesker". Nr 3-4.

1987

"Musea og opplysningsorganisasjonane: Samarbeid under utvikling." Nr 3-4, s. 30-31.

\section{8}

"Norske museer - problemer uten løsninger? En oppsummering av Trondheimskonferansen". Nr 1, s. 66-70.

1989

"Istedet for museumsbygg? Økomuseet - det åpne museet". Nr 1-2, s. 48-52.

"Fra 80-tall til 90-tall" (lederartikkel)". Nr 4, s. 3.

"Alle museer er historie om sosialhistorie" (Kenneth Hudson). Nr 3, s. 24-25. 
98 "ICOMs generalkonferanse i Haag ble en suksess".

Nr 3, s. 26-27.

"70-tall, 80-tall og 90-tall." Intervju med to formenn

(Per Hvamstad, Christian Andersen). Nr 4, s. 4.

"Fartøyvernet i Norge seiler i medvind". Nr 4, s. 8-11.

1990

"Terskler og visjoner" (lederartikkel). Nr 1, s. 3.

"Et nytt museum: $\AA$ i Lofoten". Nr 1, s. 4-11.

"Botanikk og politikk. Professor Olav Gjærevoll i intervju”. Nr 1, s. 20-25.

"Søkelys på Norsk Folkemuseum" (lederartikkel). $\mathrm{Nr} 2$, s. 2.

"Norsk Folkemuseum: 4 direktører 1994-1990 - ved to av dem". Nr 2, s. 4-12.

"Min interesse for museer er vekket gjennom kunsten. Kronprinsesse Sonja åpner MUSEUM 1990". Nr 2, s. 2-3.

"Jeg fant, jeg fant" (lederartikkel). Nr 3, s. 2-3.

"Støtt ICOM" (lederartikkel). Nr 4, s. 4.

"Fra Norge til Afrika og hjem". Nr 4, s. 4-9.

"Spredning av økologisk kunnskap" (intervju med

Bo Nilsson). Nr 4, s. 22-24.

\section{1}

"Om myter og virkelighet" (lederartikkel). Nr 1, s. 3.

"90-åra: Museene har fått en god start - intervju med fem museumsledere". Nr 1, s. 4-14.

"Norsk Fiskeindustrimuseum etableres på Melbu". Nr 1, s. 19-21.

"Museene og det nysgjerringe mennesket" (lederartikkel). Nr 2, s. 3.

"Museumspedagogikk på dagsorden i 15 år" (intervju med Svein Norheim). Nr 2, s. 23-25.

"Å kunne eller ikke kunne" (lederartikkel). Nr 3-4, s. 3.

"Et nytt nasjonalt kompetansesenter for museene kommer". Nr 3-4, s. 4-9.

"Ikke ødelegg båtene og båtbyggertradisjonen" (Gunnar Eldjarn i intervju). Nr 3-4.

"ICOM '95 - nå har vi $31 / 2$ år og gjøre det på" (Karin Hellandsjø i intervju). Nr 3-4, s. 33-35.
1992

"Cuzals - museet som leker med tiden og rommet".

(Ved J.A.G., Torbjørn Eggen og Marc Maure)

$\mathrm{Nr}$ 1, s. 18-23.

"Big Bang i museumsverdenen". Nr 4, s. 26-28.

1993

"Museums-mænd og deres skidne tøi: Museumsforbundet ble til for å forsone central- og lokalmuseer". Nr 2, s. 4-15.

3. Nordisk Museologi (redaktør 1993-2000)

1993

”Anmälan”. (J.A.G. Ole Strandgaard og P.-U. Ågren)

\section{4}

"Lokalmuseer og museumsprofesjonalitet". Nr 1, s. $75-82$.

1995

"A hundred texts on Nordic Museums in Museum".

$\mathrm{Nr} 2$, s. 203-208.

1996

"En bibliografi om økomuseer" Nr 2, s. 57-70.

1999

"The Ecomuseum in Theory and Practice. The first

Chinese Ecomuseum established". (Ved An

Laishun og J.A.G.) Nr 2, s. 65-86.

Notiser signerade J.A.G. i 1993/1, 1994/2, 1995/1, 1996/1, 2, 1997/1, 1999/1, 2.

\section{4. Øvrige artikler}

1980

"Arbeiderbolig åpnet på Toten Museum". Fakkelen, nr 7, s. 23-24.

1982

"Fotografiet som sosialhistorisk dokument. Bildene dokumenterer!" Norsk fotohistorisk årbok 1981/82.

\section{5}

"Totentreff - et samarbeidsprosjekt museum og voksenopplæring 1976-1985”. Studienytt 6-7.

1986

"Toten Museum; an open-air museum on devolution 
to an ecomuseum", report from MINOMs 3.

International Workshop at Toten, Norway 1986.

"The ecomuseums in Norway", report from

MINOMs 3. International Workshop at Toten,

Norway.

«Nouvelle muséologie, traditions et perspectives nordiques - du musée de plein-air à l'écomusée/ les minorités des régions arctiques. 3e Atelier international de nouvelle muséologie, Toten». (Ved J.A.G. og Marc Maure) MINOM. 66 p. "Ecomuseums in Norway". ICOM's 14th Gerneral Conference in Buenos Aires, Argentina. ICR International Committee for Regional Museums.

\section{8}

"Økomuseer i Norge" i: Økomuseumsboka - identitet, økologi, deltakelse, (ved J.A.G og Maure, Marc) 1988, s.138-146.

"Museene mot år 2000" i: Økomuseumsboka - identitet, økologi, deltakelse, (ved J.A.G og Maure, Marc) 1988, s. 12-15.

"Museums as an instrument of community development”. ICOM-ICR Working Conference in Vladimir-Suzdal, USSR.

\section{9}

"Arbeiderkulturen på museum”. (Ved J.A.G. og Marc

Maure). Syn og Segn, nr 2, s. 157-164.

\section{0}

Dagfinn Slettan (red) "Kulturvernet møter 90-åra:

Toten Museum - økomuseum og lokalhistorisk senter". Presentasjon av museet og intervju med John Aage Gjestrum. Heimen 1990/2 s. 66-78.

"The ecomuseum - good news in Africa?"

ICOFOM: Museum and heritage preservation,

Zambia, Zambia Heritage News Magazine, 1990.

1992

"Økomuseumsperspektivet - en viktig innfallsvinkel og utfordring i den norske museumssituasjonen." I: Nymark, Lis og John Reshaur: Rapport fra Nordisk Økomuseumsseminar Samsø, 1992, s. 47-61.
1993

"Fra folkemuseum til økomuseum. Økomuseumsbegrepet - en fornyelse av museumsinstitusjonen og et viktig instrument for lokalsamfunnet". Heimen 1993/1, s. 30-45.

"Momenter for en drøfting av lokalmuseer i 90-tallets svenske museumsbilde. Vil 2000-tallet bli lokalmuseets hundreår?" 1993. Artikkelen er skrevet for Kommunala museers samarbetsråd, og er merket med "ikke for offentliggjøring". 28 sider.

\section{5}

"Norwegian experiences in the field of ecomuseums and museum decentralisation." (Schärer, Martin R. ed.) Symposium Museum and Community II, Stavanger, Norway July 1995. ICOFOM Study Series Vol. 25, s. 201-212.

"Utstilling av levende mennesker. En historie om samisk kultur og fremmede blikk". DUGNAD, tidsskrift for Etnologi, 1995/1, s. 93-108.

"Eit museologisk perspektiv." Arbok for Bergen museum 1995. Bergen 1996.

1996

"Mangfald mellom realisme og utopi. En kommentar til NOU:7 Museum. Mangfald, minne, møtestad." (Kronikk) Konferanseavis, Norges museumsforbund, Stavanger. 1996.

1997

"Kan vi verne et telefonnummer, Om å velge framtidas kulturarv". Fortidsvern 1997/4, s. 26-27.

\section{Plandokumenter}

1988

Museumsutdanning i Norge: En norsk museumshøgskole. Utarbeidet for styret i NKKM (Norske Kunst- og Kulturhistoriske museer). $21 \mathrm{~s}$.

\section{2}

"Norsk fjellmuseum. Realisering og perspektiver." Arbeidsdokument. $47 \mathrm{~s}$. 
"Kommunala Museers Samarbetsråd. En förstudie om lokale/kommunale museer i det svenske museumsbildet." $54 \mathrm{~s}$.

1995

"Nasjonalt kulturbygg - Ivar Aasen-tunet". Revidert plandokument. $25 \mathrm{~s}$.

1996

"Dokumentasjonssenter - Ivar Aasen-tunet". Utgreiing. $27 \mathrm{~s}$.

1997

"Heilskap, historikk, bygningar og kulturlandskap". Utgreiing. Inneholder historikk omkring Ivar Aasen-tunet.

"Jugendsenteret - en nasjonal institusjon". (Ved J.A.G. og Marc Maure) Ålesund. Forprosjektdokument. 87 s. Del I: utgangspunkt for jugendsenter, - en ny type institusjon. - nasjonalt og internasjonalt perspektiv. Del II: Innhold.

Del III: Løsninger.

1998

"Rondane informasjonssenter". Forprosjektdokument. 49 s.

John Aage Gjestrums publikationslista 1992 upptar ytterligare ca 50 titlar från åren 19721992. Det är oklart om de finns publicerade. De avser bidrag till seminarier, möten framträdanden i skolor och föreningar, utredningar och notater för Toten museum. Många behandlar ekomuseifrågor, samtidsdokumentation, lokalmuseer, arkiv och publikationer. År 1983 talar han om "det integrerte museet, museet som nærsamfunnets historieverksted" under ett seminarium i Norsk Sjøfartsmuseum. Den mångårige medarbetaren Arne Julsrud Berg har framhållit John Aages betydelse
"Mjøssamlingene - struktur og utvikling 1993-98". $35 \mathrm{~s}$.

En utredning om videre utvikling og organisering av Mjøssamlingene.

"Antikvarisk bygningsbank. Forprosjekt." $42 \mathrm{~s}$. Planlegging av antikvarisk bygningsbank på Toten. Innledningskapitlet inneholder perspektiver som: - tenke globalt, handle lokalt, - fra avfall til kulturarv.

1999

"Industri- og arbeidermuseum. Gamle Holmen Brænderi, Gjøvik.” Forprosjekt. 53 s. Kapittel 1, Introduksjon og strategisk utgangspunkt, kan leses som en artikkel som tar opp betydningen av å ta vare på arbeiderkulturen. (Dette museumsprosjektet ble senere stoppet).

"Kapp Melkefabrikk: Utviklingsplan." 62 s. Viktig dokument. Kapittel 1 og 2 handler om perspektivene og historikken, og kan leses som artikler.

"Ivar Aasen-tunet. Utstillingsplan - basisutstilling." $35 \mathrm{~s}$.

även för publikationer som inte direkt bär hans namn. Totens Bygdebok, bind 4, av SveinErik Ødegaard (1984) "ble trendsetter for den nye genren av bygdebøker i Norge. ... John Aage laget modellen, layout, billedredaktør og hadde hele prosjektledelsen ned til minste detalj... Dette var uten tvil hans største bokprosjekt”. Motsvarande insats gjorde han för Berg-Nordsveens Damp-og motorbàter på Mjøsa (1996). Han var "redaktør for Mjøsa årbok (1982-83) og Mjøsa (1984-86) utgitt av museet Mjøssamlingene der han var styreformann." 


\section{John Aage Gjestrum}

\section{A brief summary of the texts on $p$. 4-92 with biographical notes.}

John Aage Gjestrum was born in the village of Bøverbru in Toten municipality, close to the lake Mjøsa in Southeast Norway. In his early teens he was deeply influenced by Johannes Sivesind, who was then director of Toten Museum and over the years came to serve as John Aage's inspiring mentor. Sivesind left Toten in 1967. Ten years later, after having completed his studies, John Aage returned to Toten to become museum director. He was only 24 years old, which was in those days sensational for a museum director in Norway. In the 1980s he continued and developed the variety of activities introduced by Sivesind aiming at the integration of collecting both of objects and oral tradition with local history research and publishing - all this in close collaboration with the local population. Doing so he soon discovered the startling affinity between the work

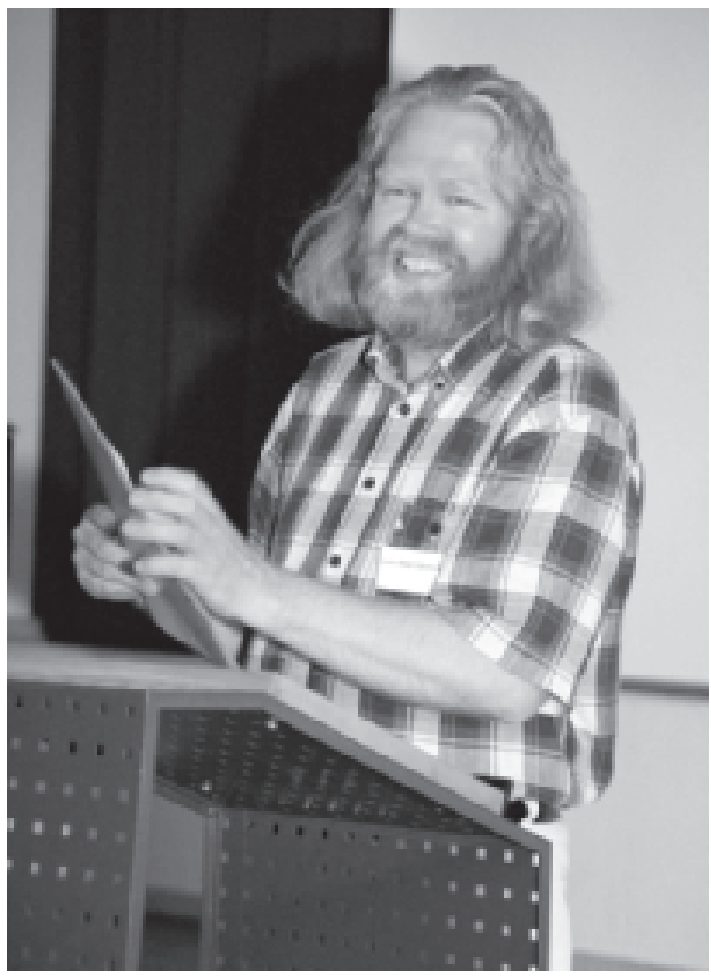

in Toten and the French ecomuseum ideas. This certainly inspired him in his efforts but also in his international outlook and engagement. Toten ecomuseum in short time became internationally known as an idea come true and referred to as a model to imitate.

From the Toten-period three texts from 1988 are reproduced (p. $4 \mathrm{ff}$ ) that mirror John Aage's commitment to local history, esp. the period when early industrialism began to affect an area of traditional agriculture. The texts were printed in the yearbook of the museum, which John Aage edited 1978-1991. They deal with the establishment of a factory for the production of matches which existed during some thirty years at the end of the 19th century. He has studied how it was financed, how technology was taken over, working force recruited, and pays attention to the problem of child 
102 labour and the living conditions of the workers.

In 1989 he became editor of the Norwegian museum journal, Museumsnytt, with which he stayed for three years and substantially contributed to its renewal. He engaged in national museum politics and began to be absorbed by the history of museums and their societal functions. He left Toten Museum and joined the Department of Museology at Umeå University to start his doctoral studies. At the same time he deeply engaged himself in international work and took on museum consultancies.

In a text (p. $21 \mathrm{ff}$ ) reprinted from Museumsnytt 1993 he examines the crucial founding years of the Norwegian Museum association when centralistic ideas confronted the visions and aspirations of the founders of local museums (folkemuseer). He explores the ensuing development in an essay from the same year, "From local museum (folkemusem) to ecomuseum" (p. $33 \mathrm{ff}$ ) where he sees the latter as a logical consequence of the former. Two years later he offers a museological perspective on the issue of museum studies in Norway (p. $53 \mathrm{ff}$ ) where he uses the history of the museum in Bergen as a starting point and the early attempts there to integrate the museum with the university.

In 1992 John Aage was already deeply engaged in the study of the small mining town Røros which was to become the subject of his doctoral thesis. One of the first fruits was the essay "Exhibitions of living people" (p. $60 \mathrm{ff}$ ) published in 1995 in the ethnologic journal Dugnad (with an English summary). And in 1999 he summarized the theme of the thesis in an article (p. $75 \mathrm{ff}$ ) reprinted from a Swedish journal for humanistic studies Tvärsnitt. He outlines the history of the small town founded in the 17 th century and put on the Unesco list of World Heritage in 1980. He shows that its antiquarian qualities were much at random selected as a national monument at the turn of the century and how the antiquarian motifs for evaluating the site as cultural property changed over the years, depending on the changing political conditions. It gives an important illustration of how cultural heritage is created and looked upon through a century. Unfortunately the thesis remains uncompleted. In a rather playful manner he discusses the problem of selecting cultural heritage in the article (p. $71 \mathrm{ff)} \mathrm{"Can} \mathrm{we} \mathrm{protect} \mathrm{a} \mathrm{telepho-}$ ne number?" (1997).

His frequent participation in several of ICOMs international committees resulted in a network which became an invaluable resource when in 1993 Nordisk Museologi came into being. He and his international friends are constantly present in the 16 issues he managed to conclude. However he was also busy contributing to the many reports and bulletins of the ICOM committees as can be seen from the bibliography.

Finally four extracts have been chosen from his work as museum consultant. The first one (p. $80 \mathrm{ff}$ ) was a study for the committee of Swedish local museums disclosing the amazing fact that there was a serious discrepancy between the official Swedish definition of a museum and the ICOM definition. This difference had as a consequence that the local museums were not included in official statistics! The second (p. $84 \mathrm{ff}$ ) is taken from a thorough study of the Norwegian Art Nouveau city of Ålesund which aims at the creation of a centre for the study of Art Nouveau architecture focussing on conservation, documentation and urbanistic ideas, The project includes an international database and network around this particular study and research. For this large study Marc Maure was his co-author. The third extract (p. $88 \mathrm{ff}$ ) proposes the establishment of a much needed resource centre and advisory service for the protection and restoration of traditional architecture in Southeast Norway. In the fourth extract (p. 90 ff) John Aage returns to the subject of early industrialisation. This time his report "From preserved milk to Viking Milk" deals with the reuse of a big factory, originally founded on the technology of 'condensed milk' and the immense produce of milk in the area.

The readers of Nordisk Museology can look forward to many reminiscences of John Aages ambition with the journal in future issues. 


\section{DESTRUCTION CAN HAPPEN ALMOST WITHOUT NOTICING}

\section{An essay in memory of John Aage Gjestrum}

\section{Maria do Céu Baptista}

A thin golden web connects me to Røros and to its industrial heritage. Knots here and there, sometimes unconscious - bits and pieces, ancestors' histories, fragments of knowledge about darkness and light, about creation and destruction. Part-time miners, part-time farmers, fireworks experts building caves for the sake of experimentation. Sometimes conscious - John Aage's curiosity about the Portuguese museum scene and his deep interest in Røros as a case study in the understanding of Norwegian museum practice and constructing a theoretical body of interpretations which might bring about a shift of paradigms in museum work.

Then there are the critical approaches of other Norwegian museum colleagues; and my own professional career: engaged first in museums and little by little in built and natural landscape as an important frame for validating (or not) museum practices. Hazardous travel through diverse but similar environments from 1995-2000: Astúrias/Northern Spain iron and charcoal mining and processing, $\mathrm{Gu}-$ anajuato/Mexico - silver mining, Krasnoyarsk, Siberia - heavy metal processing industries and of course Portugal - so many raw materials, from extraction to processing: charcoal, iron, copper, stone, sand - led me to an awareness of the difficulty of addressing a set of similar problems from within the Cultural Heritage discourse: open wounds in the land- scape which everyone neither wanted to see nor have anything to do with, a feeling of having contributed to the development of a country mixed with doubts about the real benefits of that development or about the long term costs; an epic of a life on the bread line together with an intuitive feeling for the exhaustion of the soil because of the demanding goals of the "owners".

From these travels I have realised that the extraordinary places and the ordinary (sites in the Unesco List as well as sites not listed) could start an extremely interesting dialogue. On the one hand they have a lot in common and on the other it might be illuminating to see how ideas promoted by the extraordinary sites tend to be regarded as exemplary by the 
104 ordinary sites even if the results of the actions have not yet been evaluated. There is a tendency to take what is done in the extraordinary site as authorized. Sites (listed or not) would gain more from a dialogue based on the complexity of industrial problems than from the actual situation in which the Listed Sites (of whatever type) tend to discuss their agenda in closed fora.

This is one of the reasons I have constructed this text as a dialogue between an extraordinary place (Røros) and an ordinary region (Asturias/Northern Spain). In both places there is a complex documentation (the latter containing contemporary sociological studies and research while the former is better in the field of cultural heritage). They are also connected by the extraordinary similarity in the techniques of timber construction (which was also detected in Mexico).

To the complex of industrial problems I have added tourism as a major issue for both. Frequently promoted as quality destinations the World Heritage Sites are appealing to the leisure industry of the 21 st century - but tourism is perceived as a potential take-over and resented as a solution representing short-term interests. Finally I could not help bringing in some reflections about nature and landscape: the beautification the industrial sites is a "two edged sword" Can the industrial site be preserved if the industrial landscape is destroyed?

"We could say it is black and very shiny, light, nothing lacking of its natural kind and with all the qualities required of the most precious coal".

The pits (creaderos) are described like this: "...they are the best in Spain, similar to if not better than all those celebrated abroad, easily exploitable, with a good angle of inclination, close to the surface, without obstacles to the extraction work ... they show the gifts they have received from nature and easily meet all the desires of the explorers." 1

In the words of the miners we can perceive a culture and its roots and why the crisis brings with it a special pain. Unpaid salaries, unemployment, immigration or psychological drama give rise to uncomfortable feelings of shame, of the loss of something one is entitled to, a lack of perspectives. The ghost of a glorified past, in which solidarity in the face of danger and for better pay produced images that differed according to the point of view: the miner himself ("good people") or a member of another group ("evil people"):

Nobody wanted to work in the mine, she is vicious When I start working here people use to say - watch yourself, boy, the mine is female..

J.: Nevertheless that culture which is now disappearing was the culture of the mine itself ...in our generation, and there was work, nobody wanted the mine.

R.: That's true .. nobody wanted it.

J.: I did, I was proud ...I had always been proud.

R.: The mine gave more solidarity.

J.: It was more tender, more like family.

R.: Worry about the problem of the others ...if they have a problem then you show solidarity. Now everyone looks after their own interests

J.: But still, the mines, still...

R.: Still it is about solidarity...

J.: Still is ....and that is a culture in itself ....it is still there ...the roots are still there.

3. Well when I started ...it was bad, relatively bad ...you have to assimilate, you and us we have to assimilate... The miner has to be very attentive, for security reasons, inside the mine... There is a big feeling of unity ...there is a feeling... I cannot express it really, yes...

3. A great strength ...that is pulling you. The mine demands a lot. ${ }^{2}$

4. It was the mine that changed not the miners. The miner - apart from the hardness of his work - has a 
nobility, has a great heart ....and shows solidarity ...we spend seven hours together, more than with the wife ...in that sense we are united.

Salvation through culture for a community that wants to resist oblivion, that wants to continue to live when the industry - the main raison d'etre - disappears, is not an easy road to tread.

Beyond the fact that I have no prospects for my future, you live an unreal life, because it is a lie. Well you live ... you don't have any financial problems because you live with your parents. But you are not living the life you should live... For instance I am 33 years old and I am living as if I was 17 . You depend on what you are given at home and you cannot see any other way of organising yourself. This does not help you to become an adult ...you cannot live a life that corresponds to your age... ${ }^{3}$

Disbelief is a common feeling mainly in connection with the community's economic and psychological revitalisation. If cultural tourism has to play a role - it is certainly not the non-controversial suggestion one might be led to believe.

It is not strange that many enthusiasts, researchers, associations and other entities, and professional bodies are starting to show their preoccupation and their interest in developing projects which might lead to the protection and reuse of this heritage. Examples such as ...cultural tourism or industrial tourism ...with the idea of promoting initiatives ...that might give the past of this region a future. ${ }^{4}$

Tourism will not bring extra value to the city... The problem with the tourist policy ...we are not against it ...but the only thing we did was to perform a cosmetic operation on the city...

Sometimes I have the impression that we are creating a giant with feet of clay...I think that the development of this city is based on a lie ...we work hard at the infra structures - which were necessary - at the beaches - it is true that tourism got a lot of help - but we are not looking at it from the perspective of a longterm future... ${ }^{5}$

It could be interesting to compare these feelings with expert opinions:

Culture and cultural heritage are crucial to people's identity, self-respect, and dignity. This applies both to affluent and poor societies ... Provided these basic facts are understood and serve as a guideline for presentation and communication between tourists and the local population, cultural tourism has a great potential for improving understanding and respect among different cultures, and from a long term perspective may be regarded as a tool for creating and preserving peace. ${ }^{6}$

A long stay in Røros/Norway - the first industrial world heritage site on the Unesco list - was to play an important role in my own understanding of the situation and led me to pose some questions which apply to the extraordinary case of Røros as well as to the impact of the Røros experience on an ordinary case such as that of Asturias. As the industries copied models and imported knowledge I hoped that some of the reasoning around extraordinary industrial sites might interest ordinary regions in establishing and planning their own future and the actions they might take. I asked questions like: What was the real effect of the special heritage activities on the daily life of a community? How does the extraordinary distinction act upon the place? Does it promote revitalisation? Is it helping in the construction of a new identity? Is it adding real value to the place or deleting it? Is there any specific purpose in placing an industrial site on Unesco's list?

Finally: Can achieving cultural understanding of a situation make a difference? 
AN EXTRAORDINARY SITE?

There is a set of natural and human opportunities often forgotten but always present: rivers of significance but also with easily harnessed waters, favourable landscapes inviting the design of means of communication or good natural harbours, forests, cheap labour and interesting political-economic frameworks: conflicts, extreme needs for raw materials, internal political changes leading to a change in social perspectives, progress.

Today when all industrial nations put great effort into searching for coal, it is the magic agent of production, the most powerful engine in all factories, the element necessary to reduce distances, travel the seas in safety and transform all nations in one, we couldn't possibly be more excited about the samples of this invaluable mineral. $^{7}$

Røros was before existing - Unesco's first industrial world heritage site was born to the map from a fruitful geology, rich in copper (exactly in 1644 when Norway was ruled by Christian IV of Denmark). Two years later the king gave the Mining Company - which had shown sufficient knowledge and competence - the privilege of using the local resources and human labour force. This extraordinary event almost transformed the dull border zone into a battlefield, in which Sweden became the enemy instead of the neighbour. ${ }^{8}$

The threatening situation that resulted came close to a declaration of war and led to the emerging town being completely burned down (1678-79). However Røros remained Norwegian after the conflict. Røros was to enjoy a favourable position, free of competitors, when European wars created a demand for its precious raw material for use in the casting of cannons for the army and navy. Historical change:
When the French destroyed the factories in Navarra new opportunities arose for those in Asturias, ... a new factory (was opened) removed from the French border but close to the point where the rivers Nalon and Trubia meet. They would produce ammunition. Again the coal mines in Asturias depended on the needs of the Army. ${ }^{9}$

These apparently simple but essential characteristics bestowed the place were to become an extraordinary birthmark (which can also be found in many other ordinary industrial sites) that seemed to forecast a specific outcome: note the relevant dialogue between the natural and the artificial, between nature and man's use of it.

A birth brings with it a movement towards the exterior, towards light. But Røros was born from a movement towards darkness, towards the womb. Røros as a visible physical reality corresponds to an empty invisible dark hole.

A hill named Carbayín caught fire .... and by chance it reached a certain area ... which was burned for 5 months... While my grandfather was hunting he noticed that the ground was soft beneath his feet .... and examining it more carefully he realised that it was on fire ...he suspected that he might be on top of a coal mine. He thought this because he had read some articles written by English writers. ${ }^{10}$

The expansion of the visible Røros in all directions (the famous circumference - a symbolic circle mainly used by the Company to exclude all possible intruders and to extend the powers granted to it by royal privilege) corresponds to an equal but invisible expansion of its pits.

The last annual report (1976) written just before it declared bankrupt is full of optimism and states that the copper found was sufficient to sustain the Company for more than 300 years. 
This constant need to expand, the anxious search for the future never ceased. But unexpected events played a trick on this expansionism. A problem with one mine was enough to bring drama to the small community and caught Røros unprepared. A leitmotif: the industry collapses almost without notice.

Q. - when did the crisis start here?

2. - what, that this was going to happen?

3. - In the 90 s?

2. - but no, my child, I think it was before that, around the $60 \mathrm{~s}$.

1. - the crisis in the mines started when the pits started to close... who could see it before that?

2. - Everyone, child. Since the first strike in ' 62 , one knew ...

1. - No! The miners didn't know. I remember saying when S. José was closed: They are closing St. José! And they replied: No, they will not close it. There is a lot of coal. And when they did close it, the majority did not know!

3. - So we are living above our means, I would not consider this a crisis. ${ }^{11}$

They had lived their adult lives without any crisis. There were no models for how they should act in times of change. The company management had been successful, but conventional, not to say conservative, and it was deeply involved in the organisation of the community. The model that the management left behind was adopted. Røros survived ${ }^{12}$, but this time on artificial respiration carried out by the owners of the, once again, less interesting border zone: the culture and tourist industries. Røros once again became an "extraordinary place", a World Heritage Site.

International tourism is essentially a phenomenon peculiar to industrialised countries...

Driven by a variety of needs to attempt to earn a living from tourism, communities sell not only their labour but themselves, offering themselves as merchandise; as a result, they are to some extent converted into a fetish, a spectacle, and reduced both to serving the function expected of them by tourists and to accepting what the tour operators offer them in exchange. In the arts, music, dance and crafts, the focus is on developing what can be sold. ${ }^{13}$

\section{WHAT IS IN PLACE DOES IT REALLY EXIST?}

1981. In this motionless/empty place a scenario quickly emerged: what exists is just a domain for action, an arena; what is absent, the raison d'être, the intangible, has been transformed by alchemy into a new resource: the certainty once again a reality - the unlimited expansion. Following what models? According to what beliefs?

Heritage professionals were already in place. Interested in the site they saw an opportunity, a bargain even - heritage also has sale prices! Part of the mines, tools and smelting hut were easily bought and listed. But with time knowledge increases and it became necessary to include more and more elements, a bigger area. And the promised expansion with the explosion of data, resulted in conflicting interpretations. Awareness, understanding and knowledge, not always well managed led to action. Did Røros miss the opportunity to have a break, an interval in the success story? A "no man's land moment" that could have allowed some creative considerations, like a certain awareness of the negative, of the option to step back, of the possibility of letting the disharmony show?

John Aage Gjestrum detected something singular about the Røros case. Røros was not a simple open-air museum. It had always provoked national debate. At that time he was 
108 following the development of the ecomuseum experiences and he had detected that in many cases the management of museums had not been able to incorporate the gains of the cultural experience they were both reflecting and promoting.

Røros had been fully documented for several reasons, including a military mapping of the region between 1807-1814. The Mining Company had also kept detailed records of exploitation, investments and gains as well as explorations, control of the human workforce, meetings, agreements and conflicts.

But Røros also had a century of documentation concerning the conservation of its constructed heritage, a history that had been under public scrutiny more than once: at the turn of the 20th century, simultaneously with the active construction of a new cultural identity in Norway. Røros played an important role in the national discussions about the cultural identity of a nation. At that time and influenced by the discussions surrounding the open air museum in Oslo, Røros adopted a similar type of management. Later on, during the 30s, it became clear that instead of one Røros had three archives: one covering the history of farms and farmers in the region, another kept by the mining company, and a third concerning the Church. In 1976 during the bankruptcy the labour union tried very hard to promote the miner's identity as the core of the Museum representation. This gave birth to a separate museum object Olav's gru$v e$, which was built without benefit of an industrial archaeology programme, perhaps due to the highly political goal that the project represented.

The discussions surrounding the Røros heritage and its role repeatedly arouse national interest - as if the birthmark keeps growing.
History has not yet come full circle, even if, in 1996, the museum was placed under the umbrella of a Foundation, Stiftelsen Rørosmuseet.

\section{THE MISSING LINK - OR THE OBLIGATION TOWARDS THE WORLD}

It is easier to raise this question when we are talking about an industrial community in a World Heritage Site, situated in a country with a well developed macroeconomy. But the issues around World Heritage Sites are relevant regardless of economy or geographical situation. They have the power to increase individual understanding of certain situations and point out how powerful a force for transformation can be if one is able to react as participant instead of an observer. We are often caught and trapped in certain roles. We have to be aware of the dissonant sound that strikes our ears so as not to miss the message. And when we are representing it both in words and images, let us make clear the standpoint from which we are making the representation. For some reason the industrial sites seem to be ideal places in which to address unique and very contemporary phenomena concerning the values of the World Heritage Sites.

In 2002 the discussion about intangible heritage will be the subject of the next ICOMOS general assembly in Zimbawe. Let us take advantage of this to introduce the issue. Otherwise many promising industrial heritage sites could easily be transformed into meaningless places of contradictory actions.

To deal today with the reality of Røros - as a meaningful example for other industrial heritage sites - means dealing with fundamental issues: learning how to cope with the industrial activities which, from the very start 
were generated and depended on global circumstances. One has to be fundamentally interested in the site's activity, reasoning and role. This has become an obligation arising from our daily confrontation with the debris caused by their activities which so often end up as the responsibility of the Ministry of Culture and the Environment. Once the resources or its needs are exhausted, the land returns to its owners. And the pollution which was the result of the industrial exploitation suddenly acquires a new owner with double and contradictory responsibilities: to keep and to clean. This clearly points to a need: give time to Time or in other words - use Time to address the new realities which were generated by long periods when there was an absence of harmony

...The prospects are very bad, but the situation in itself nowadays is not bad. We live well. We know that there is a crisis .... and as we see that there is no way out we see no way to improve our life. We do not try to create new things. Everybody knows and everybody accepts. ${ }^{14}$

The renewal of discussion surrounding the issues that result from the closing down of an industrial activity and its transformation into a Heritage Site has international relevance.

What does it mean to become a world industrial heritage community instead of being an industrial community?

What responsibilities does an extraordinary industrial community have towards other ordinary communities facing industrial decline?

What responsibilities does an industrial heritage community have towards regions that can become the targets of industrial development?

The greedy expansionist movement that is at the core of industrial activities must be 109 analysed. Issues such as pollution, health, heavy work as well as the feelings of shame and "heritage" among individuals must be set against real experience in a new and total account of gains and losses. The total effect on the landscape, on visual perception and people's subjective claims to a clean industrial heritage must become a priority for further evaluation and the basis for plan of action.

Ordinary industrial regions must be made aware by the extraordinary industrial sites that their solutions have not yet been fully investigated and that evaluation of the actions taken in the name of industrial heritage has not yet really begun. The ground is a minefield. To buy out, for cultural purposes, the ruins of industrial activities are not cheap and in many circumstances do not provide an adequate response to the feeling of despair that strike a community when decline suddenly closes the door on what were, until yesterday, optimistic enterprises.

There has to be awareness that the spending of time and money is only worthwhile if there is an aim, a strategy and a plan of action that can be tested and evaluated and changed without major dramas. Between heritage intentions and heritage actions there are gaps which consume finances and weaken our perceptions of what is to be protected and what can be erased by uncritical planning.

Finally it is important that one learns to foresee the future regarding heritage management, not through looking in a crystal ball, but understanding, testing and evaluating the actions we take in the name of heritage preservation.

These tasks cannot be reserved to the cultural actors or claimed by them: if the indu- 
110 strialists are not aware and responsible, interested and engaged, involved and truly sharing in these preoccupations, then the capacity to shape a future is not even a possibility. More than ever it is becoming clear that heritage for the sake of heritage is no longer interesting.

\section{FROM AN EXTRAORDINARY INTERNA-} TIONAL POSITION TO AN INSTRUMENT FOR LOCAL AND GLOBAL TRANSFORMATION

Røros is the unique child of a slow moving nature where forest does not grow fast and where farming is not important enough to promote competition for the use of the soil. Røros is a unique Norwegian settlement and has therefore every possibility - including the Unesco stamp - of becoming a cybernetic arena for relevant discussions and actions around at least the following issues:

With its 100 years of experience as a built heritage Røros is well positioned to ask what is building conservation in an industrial community. If the significance of the place is to be kept we have to learn to operate with more than one alternative answer to allow our minds to start a systematic approach, set in a framework of total perspective and understanding.

In 1919 the First World War began .... and the diamond mining fell into SA hands and with that expertise available, richer deposits were discovered along the Orange River which led to the establishment of a new town... Gradually Luederitzbucht collapsed, shedding its population and industries. The school closed, buildings became obsolete and urban decay set in. ${ }^{15}$

Universal values bring with them universal errors which can lead to complete loss of cha- racter in a site as well as a real devaluation of individually owned properties. Today's information society and the political need to advertise actions in heritage sites can play a big role in spreading less correct solutions. Joint ventures in training for new visions among industrial heritage specialists, house owners and craftsmen might find in Røros a rich soil in which to develop. We are a long way from the 60s when industrial archaeology first started to attract the attention of the heritage professionals. The scope of the discipline has expanded. We are no longer targeting a wider representation (or a representation of the different) in the heritage discourse. We are, or should be, heading towards the construction of a totality that might serve as a reference for world industrial life. If one could check authenticity against this frame we would quickly understand how the definition "authentic is something that has the authority of its original creator" could lead to a completely different understanding of the conservation process in Verdenskulturminnet Røros ${ }^{16}$.

The conservation and restoration of industrial landscapes - this means actions directed towards the preservation of a significant identity (after the disappearance of the industry) as a key tool in the development of a living community or in its transformation into a mummified shadow of its past. To act in this field we need a total understanding of the place - how it has absorbed and absorbs human actions (before and after the heritage designation).

Does this mean that we regard nature as a stable, balanced and beneficial aspect, giving us all we need or lack in order to build our environment? And is this a nature we understand as an unlimited source of goods that creates the place and absorbs human action? What 
then is the role of the quarries... Time and construction have changed... When we think about old quarries, their traces seem to be an inheritance from past civilisations improved by time. However in today's quarries we must find out why we only ask ourselves about these involuntary signs of an action always justified by growth... The quarries that we now see are interruptions in the landscape. They are parenthesis spaces that keep in suspense the continuity of a world made up of ... episodes of what we can call natural and artificial... They talk about strain and crisis, but we should give them a vote of confidence. ${ }^{17}$

An understanding of the transformation of a former natural landscape into an industrial and rural settlement and later into an urban landscape cannot be attained without an holistic understanding of the interaction between man and nature as well as those beliefs developed by man over time But Awareness of that interaction has to become an engine for change in terms that are relevant to contemporary life. This implies a subjective understanding of one's own position rather than of each one's individuality. In this sense the holistic interpretation of the transformation processes and its communication asks for surrender: industrial heritage sites are complex and difficult to address but their interpretation can no longer be left in the hands of a cultural elite. Industrial heritage sites demand to be liberated from that niche and Røros might be a key place in which to postulate an experiment: the Unesco stamp seen as a condition and not as a life status.

\section{ORDINARY VERSUS EXTRAORDINARY \\ - A CHANGE IN CONDITION,}

A CHANGE IN BELIEFS

Sites and towns known for the significance of their heritage have an opportunity and an 111 obligation to make visible their intangible values whenever they are acknowledged as parts of World Heritage. This acknowledgement forces a change in the condition of the site itself which can become an arena for experimentation and can pioneer dialogues.

The battle will always be between what is true but strange and what is appealing and popular. And one must constantly remind oneself that this battle is ongoing. ${ }^{18}$

Any ordinary reasoning can prove that the driving force of industry still lies in a belief in free market forces and in their expansionist potential. These beliefs are in complete contrast to the minimal principles that have to be adopted for a relevant preservation of an industrial heritage site. Any promotion of actions which eschews a shift in the condition of the site should not be given our support. The same applies to actions that promote simplistic changes. The present extraordinary speculation around World Heritage Sites, often developed and expressed at the highest levels without local involvement, has not yet proved beneficial for the specific communities. In the case of the industrial sites they endanger and make difficult the natural message to the industrialised world: destruction is still happening almost without being noticed.

I hope that one day the ordinary sites will be able to participate in a multi-voiced dialogue with the extraordinary sites - a dialogue with an echo (to put it in a way familiar to John Aage) - and prove that distinction is a condition to be achieved by the pure desire to defend fundamental values and by a plan of action that faces up to conflicts. 


\section{Notes}

1. Rafael Anes Álvarez, Asturias, fuente de energia El carbón asturiano en la economia española, Hunosa, 1997 (p. 54 - extracts from a Memory presented by the Ministry of Commerce in 1850 describing the qualities of Asturian coal).

2. AAVV, Asturias: el declive the una region industrial, Trea, 1996, Gijon, Asturias (chapt. VI La empresa minera HUNOSA, extracts from open interviews).

3. Ibid. (Chapt. VIII Gijón en el declive industrial de Asturias).

4. Asturias: patrimonio industrial y turismo cultural, nuevos recursos para viejas estructuras, in ABACO, n.19, 1998.

5. In Asturias: el declive de una region industrial (Chapt. VIII).

6. Sustainable tourism and Cultural Heritage, Nordic World Heritage Office, 1999

7. Asturias, fuente de energia, Hunosa, 1997 (p. 54, quotation from a presentation by the Ministry of Commerce in 1850).

8. Interesting enough today Røros is promoting a pioneer programme concerning configuration situations in world Heritage Sites. It is perhaps symbolic that local fiddlers seem to play a musical metadialogue with high tones during martnan (the winter market) while at the same time a theatre group puts on a successful play dealing with the battle against the Swedes. Pure anachronism? Personal/national empowerment in times of latent crisis? A search for ways out? Or is this an invitation to start imagining identity in new ways? If the answer to this last questions should prove to be yes perhaps we are witnessing a performative way out - a direct implication of the body in the representation of the wound.

9. Asturias, fuente de energia, Hunosa, 1997.

10. Ibid. p. 17/8. My summary of a report on mines in Asturias.
11. Asturias: el declive de una region industrial, Chapt. $\mathrm{XI}$, The discourse of the crisis in the region, $\mathrm{p}$. 428 extracts from open interviews.

12. Braathens $\mathrm{A} / \mathrm{S}$ closed the airport several times, a fact which clearly indicated to the community its economic fragility. Studies show that Roros does not have a sound development if compared with neighbouring communities which have not been recognized as having a special heritage and do not receive extra funds for their management.

13. François Ascher, Tourism, transnational corporations and cultural identity, Unesco, 1985. (p. 13 and 44)

14. Asturias, el declive de una region industrial, Trea, Chapt. VI.

15. Walter Peters, Luederitzbucht: Centre of Jugendstil in Namibia, paper given at the Celebration of Craft Conference in Riga, 1999 promoted by Kulturvernakademiet/Røros.

16. Preservation of Wooden Buildings in World Heritage Site Røros 1995 -1999: lessons learned.

17. In paisage de les pedreres de menorca, ed. Rosa Barba i Casanovas, Barcelona, 1999.

18. Ola Jonsmoen, Blood, sweat and tears - a meditation on aspects of cultural tourism, 1999 (paper presented to an ICOM meeting on The Charter of Cultural Tourism, at Røros).

Maria do Céu Baptista, freelancing art curator, Lisbon, Portugal.

Currently working at Santiago de Compostela, Spain. E-mail:mariabaptista.kva.lisboa@netc.pt 


\section{SKRIFTEN PÅ VEGGEN - OG I MONTRENE}

\section{Olav Aaraas}

Nä jeg har vandret $i$ utstillinger verden over, har jeg ofte kjedet meg. Det har vart litt flaut å innrømme det, jeg har slitt litt med selvbildet mitt, folt at jeg ikke var riktig akademisk nok, at jeg burde vare oppslukt av historien og av gjenstandene som var utstilt der. Jeg har folt meg mer som et litt forvirret, vanlig menneske (jeg har av og til litt folelsen av at vi museumsfolk ikke er det), jeg har ofte fätt mer utbytte av à lese Anders And enn mange av museumstekstene - og i tillegg hatt det mye hyggeligere. Jeg har med andre ord ikke vart noen eksemplarisk utstillingsgjenger, men har ofte folt meg rastlos, lengtet etter at noe skulle gripe meg, lofte meg inn i stoffet. Kanskje er det slik mange hevder, at det er de nye mediene, underholdningsindustriens inntog i våre liv, som gjor oss mindre mottagelige for museenes formidlingsspråk.

Etter hvert som jeg selv har arbeidet med å lage utstillinger, har det $i$ tillegg senket seg en slags hinne mellom meg og utstillingene, et filter som siler ut selve innholdet og legger det i en hjernehalvdel (den høyre, kanskje?), mens den venstre arbeider med selve mediet og forsøker å analysere hva det egentlig er som skjer i utstillingssalen. Hva som skjer med meg. Vi tenker jo alle først og fremst på oss selv.

Altså: Hva er det som skjer med oss når vi kommer inn i en utstillingssal? La oss tenke oss museumsstyrer Musum fra et større norsk friluftsmuseum på sitt første besøk i steinalderavdelingen i Historisk Museum en kald blåsende høstdag:

Den store glassdøren var tung å skyve opp, så tung at Musum måtte legge all sin tyngde til for å klare å åpne den. Da den først gav etter, skjedde det med slik hurtighet at han falt ukontrollert inn i rommet og måtte ta seg for med hendene for ikke å slå hodet i det harde marmorgulvet. Han krabbet seg opp på knærne og løftet blikket. Han befant seg $\mathrm{i}$ en stor, mørklagt sal med høy takhvelving. Så høy var den, at han knapt klarte å øyne taket oppe i det sorte. Langs veggene lyste det innbydende bak store glassruter, en varm verden av fortidsskatter trygt plassert bak alarmer og låser. Som et enormt akvarium, tenkte han og reiste seg opp. Det var omtrent som å vandre ute en kald vinternatt og se inn gjennom vinduene til fremmede mennesker. Av og til hadde han grepet seg selv i å ta på seg brillene når han gikk slik, så han kunne se 
114 detaljene inne i stuene til dem som ikke hadde trukket for gardinene. De svømte omkring som fisker der inne, mellom lamper og bokhyller, noen av dem satt i det flimrende blåaktige lyset fra TV-apparatet. Det rykket så nær at han følte seg som en kikker, selv om han bare vandret forbi ute på gaten. Her var det annerledes. Gjenstandene i de store montrene var satt der bare for hans skyld, de nesten smilte til ham i sin fiberoptiske stjernenatt. Han selv var alene i en kald nåtid, fortiden lå der og ventet som en trygg sikkerhet om at her hadde levd folk før ham og skulle fortsette å gjøre det lenge etter hans tid.

Oppe på den høye veggen hadde en projektor med lysskrift avsatt navnet på den tidsperioden han var kommet inn i. Eldre steinalder forkynte den med all mulig tydelighet. Eldre...tenkte han. Begynnelsen på historien, med andre ord. Han følte en varm forventning ved å skulle få ta del i denne beretningen. Hvilken vei skulle han begynne? Han bestemte seg for å gå med solen rundt rommet og starte til venstre for inngangsdøren som for lengst hadde slått igjen bak ham og antakelig ville være umulig å få opp igjen. Han var fanget i fortiden. Den første monteren han kom til hadde nummeret 28 og inneholdt en rekke stykker flint av ulike farver og størrelser. Selv om han altså tydeligvis hadde begynt i feil ende av lokalet, stirret han nærmere på de små steinflisene. Hva kunne dette være? Hver av dem hadde fått et nummer, trykket med hvitt på et mikroskopisk stykke gjennomsiktig plast, slik at den mørkeblå fløyelen ikke skulle forsvinne. Det hele var meget estetisk. Altså måtte det finnes en liste med nærmere forklaringer som numrene henviste til. Det tok litt tid før han fant den. Den viste seg nemlig å være satt i sorte bokstaver rett på glassruten, men på grunn av den mørke fløyelen inne i monteren, var den ikke leselig. Han kjente den dog med fingertuppene, nesten som blindeskrift. Han snudde seg og gikk forbi inngangsdøren igjen, til monteret på dens høyre side. I det dempede lyset ble han nå for første gang oppmerksom på en stor tekst som var satt med grå plastskrift på den like grå veggen. Også denne svært estetisk og lite prangende, nærmest usynlig. Den røpet seg ved at plasttypene var av et noe blankere materiale enn veggmalingen og at de derved reflekterte lyset på en annen måte. Han stilte seg opp og leste:

Mangeårige og inngående studier av avsmeltningsprosessen viser at den store smeltningen av isen må ha foregått relativt synkront på hele den skandinaviske peninsula. Vitenskapelige undersøkelser, ikke minst utført av dr.glaceol. Peter Eisberg, har nu med betydelig grad av sikkerhet kunnet konstatere at det store ismassiv frem til ca. år 12.000 f.Kr. hadde sin utstrekning helt sør til Sjælland og Skåne. Den bakre grense for den periode, da det med noen grad av sannsynlighet kan ha levet mennesker i Norge må derved, om ikke uten visse forbehold, sies å være determinert. Det postglaceale Norge hadde fătt sitt preg av istidens veldige naturkrefter. Ismassene hadde sprengt fjellet i fjorder og kløfter, landet var skurt og nakent, sten og fjell, morener av rullesten og grus, oppskrudd, steinet leire og sandbakker etter breelvene gav landskapet sin karakter.

Musum leste ferdig. Mens han leste, merket han at tankene hans øyeblikkelig gikk til en brevandring han nylig hadde hatt på Jostedalsbreen og derfra direkte videre til en pike han hadde truffet på Sotahytta, ved foten av breen, etter en betydelig dagsmars. Hun hadde vært vidunderlig vakker, det hadde vært kontakt ved første blikk, hun hadde smurt hans verkende føtter med velluktende salver, og de hadde delt både hans egen cognacrasjon og resten av hennes flaske med Gammel 
Dansk før de hadde gått til ro tett inntil hverandre alene oppe på hemsen, hete $\mathrm{i}$ hver sin sovepose, men med glidelåsene åpne, og da de våknet neste morgen, hadde de undret seg over at ikke breen for lengst var smeltet...

Da han kom til seg selv, oppdaget han at han hadde lest hele teksten uten å skjønne hva som sto der. Ordene hadde gått tvers gjennom hodet hans. Sammenliknet med hans kjærlighetsopplevelse der inne i Breheimen var teksten uten betydning. Og hvem i helvete var denne dr. Eisberg? Etter hans navn hadde han ikke fătt med seg mer.

Hans postglaceale bekjentskap med Bergfrid - ja, hun het faktisk det - hadde blitt kort. Hun viste seg neste morgen å arbeide $\mathrm{i}$ reklamebransjen, som tekstforfatter, og de hadde kommet opp i opprivende diskusjoner om hvorvidt man kunne tillate seg å manipulere folk med ord for å få dem til å kjøpe varer de egentlig ikke hadde bruk for. Som gammel sosialist hadde Musum tatt bestemt avstand fra en slik tanke. Bergfrid, derimot, hadde irritert seg over hans gammeldagse og museale holdninger til det frie initiativ og gitt både ham og museene det glatte lag. Hun hadde vært på Historisk Museum og ergret seg grønn over utstillingstekstene.

- Hvorfor er dere så forbasket snirklete og omstendelige? spurte hun, Hvis jeg vil selge en sjokolade, behøver jeg vel ikke fortelle dem om hvem som eier fabrikken og hvilket skonummer han bruker, om næringsinnholdet og kakaobønnens historie!

- Nei, men du må da fortelle folk hva det er du vil selge dem! hadde han innvendt.

- Hvorfor det? spurte Bergfrid, Det står jo på innpakningen! Hvis folk vil vite kakaobønnens historie, kjøper de seg en bok! Jeg skal selge, jeg, og da må jeg uttrykke meg slik at de gidder å lese det jeg skriver! Hvis du skal nå frem til folk, må du vise dem at du har 115 noe å si som betyr noe for dem. Noe om livene deres, for eksempel! Nå skjønner jeg hvorfor det er så mange kjedelige museer. Hvis alle museumsfolk tenker som deg, kommer de jo aldri til saken!

- Vi som forvalter kulturarven har en plikt til å formidle vår kunnskap videre til nye generasjoner, hadde Musum begynt og i det samme hørt hvor selvhøytidelig det hørtes ut.

- Er du sikker på at det er det du gjør? hadde Bergfrid avsluttet, og dagen etter hadde hun vandret videre vestover, mens han hadde tuslet seg den andre veien, tilbake til bilen nede i Skjåk.

Han hadde lovt at han skulle ringe henne, men det hadde aldri blitt noe av etter den samtalen om tekstene. Han hadde folt seg tråkket på, hånet og misforstått. Men etter som ukene gikk, hadde hans forurettethet fortatt seg, og han hadde bestemt seg for å ta en tur til museet selv. Den nye basisutstillingen på historisk museum, tegnet av den anerkjente arkitekten Arnulf Ben, hadde fătt mange lovord. Og nå, lørdag formiddag midt på gulvet i steinalderen, begynte han å forstå hva hun hadde ment. Han ruslet videre til neste tekst som var nesten like vakker og usynlig som den første og lød slik:

Jordbunnens karakter var for en stor del bestemt ved en senkning av landet etter istiden og følgende ny hevning. Planteliv og dyreliv fulgte de vekslende klimatiske forhold, som selvsagt også i høy grad var bestemmende for de eldste menneskers utbredelse og levevis i et land som Norge. Det er likevel hevet over enhver rimelig tvil at mattilgangen - særlig langs kysten - må ha vært god i forhold til folketallet. Zoologen prof. Elgbjørn Gaup har påvist at de tidligste samler- og jegerkulturer har kunnet tilfredsstille sine behov for næring i form av vilt og fisk uten overmenneskelige anstreng- 
116 elser (Gaup, 1957). De mest benyttede næringsemner kan synes å ha vært hjort og elg, mens man langs kysten også ser ut til å ha fortært betydelige mengder fisk og skjell. Det må dog understrekes at funnmaterialet fra denne perioden må ansees som svært bristfeldig og upålitelig, og fremtredende marinbiologer, først og fremst førsteamanuensis Selfinn Tangen, har vært blant dem som har stilt seg svært kritisk til Gaups konklusjoner (Tangen, 1963).

Også nå falt han ut. Han grep seg selv i å bli utålmodig, forsøke å lese hele teksten i ett øyekast, med den følge at han ikke fikk med seg setningene, de ble til usammenhengende rekker av ord som rullet om hverandre i hodet hans. Det kom plutselig for ham at den vakre utstillingen til Arnulf Ben var fullstendig utilgjengelig i sin skjønnhet. Han famlet i lommen etter mobiltelefonen. Det lysende tastaturet virket trygt og tydelig her inne $\mathrm{i}$ istiden, og displayet lyste som et grønt vindu i håndflaten hans. Med skjelvende hender tastet han ned sitt budskap. Det var ikke lett, for displayet tok bare 160 tegn og kun 16 på hver linje, altså ikke mer enn ti linjer:

$$
\begin{aligned}
& \text { Bergfrid, } \\
& \text { jenta mi! } \\
& \text { Er alene på } \\
& \text { Historisk Museum } \\
& \text { og her er kaldere } \\
& \text { enn på breen. } \\
& \text { Hvor er du? } \\
& \text { Jeg elsker deg. }
\end{aligned}
$$

Så la han seg på ryggen på den grå Erik Jensen-sofaen midt i rommet og stirret opp i taket. Glassmontrene rundt ham var forvandlet til en ugjennomtrengelig mur av uforståelig fortid. Han merket til sin forskrekkelse at han var i ferd med å fylles av et forferdelig og urettferdig hat mot arkitekt Arnulf Ben og førsteamanuensis Selfinn Tangen. Hvilken rett hadde de til å holde ham for narr på denne måten? Hvorfor lokket de ham inn i et rom som var umulig å finne frem i og lot ham famle rundt i mørket etter uleselige rebuser? Hodet hans svimlet, og han måtte ha vært borte noen sekunder. Da han våknet, søkte blikket hans opp i den nyklassisistiske takkuppelen, og ettersom øynene hans vendte seg til mørket, trådte det frem en setning høyt der oppe, skrevet med romerske bokstaver som sto i stil med arkitekturen for øvrig:

$$
\begin{aligned}
& \text { Kundskaben om } \\
& \text { Vore Forfædres Liv } \\
& \text { viser Vejen } \\
& \text { mod vaar Fremtid }
\end{aligned}
$$

Ikke mer enn det. Like kort som en tekstmelding og tydelig og klart for alle i hundre år, helt til arkitekt Arnulf Ben hadde skrudd av lyset. Han måtte ut av dette rommet. Han reiste seg resolutt og skrittet bort til den tunge glassdøren, tok i av all kraft og rev den opp. Denne gang gled den mye lettere, den svingte på hengslene og smalt i veggen med et brak som ga gjenlyd i hele det marmorbelagte vestibylearealet. En vakt kom umiddelbart løpende og spurte forskrekket hva som var i veien.

- Ingenting, svarte han kort og gikk på toalettet for å få litt vann i ansiktet.

Toalettet hadde ikke gjennomgått samme fornyelse som utstillingssalen. De hvite flisene var sprukne og misfarvede, kranene var fra århundreskiftet og hadde dryppet lange, rustbrune striper ned i servantene. På den ene vasken sto en flaske flytende Lano håndsepe. Han tappet i vann og grep den gule plastflasken for å pumpe ut en liten klatt av den velluktende kremen. Her var det enda en melding:

Flytende Lano håndsepe

...Like ren og mild

som Lano alltid har vært 
Bergfrid hadde rett! Det var ikke vanskeligere enn dette. Mer var det ikke nødvendig å si. Men hva med presisjonsnivået? Mobiltelefonen vibrerte iltert nede i lommen hans. Han rev den opp og leste meldingen.

Når vi er sammen
skal alle skjermer
svartne
all ringing
stilne
alle ord hviskes
lavmelt.

Herregud! Hvordan kunne han lese tekstene til Selfinn Tangen etter dette? Han satte seg på toalettskålen og skrev, med en inspirasjon han aldri tidligere hadde kjent. Det lille grønne displayet strålte grønt i halvmørket.

Finnes vinduer
til sjelen,
varmt grønne
i mørket.
Vet du er
der inne.
Lyset tent
gardinen fra
små glimt.
Ser du meg?

Så tok han trappen i fire steg, krysset vestibylen og dyttet opp døren til steinalderavdelingen med en kraft han ikke hadde ant at han hadde. Mens han satte seg ned i Jensensofaen og trakk frem en notisblokk fra vesken, durte det $\mathrm{i}$ lommen igjen. Hjertet hans hamret i brystet mens han leste:

Smiler du

når du skriver

at du elsker meg?

Trykker du

telefonen mot hjertet

på museet

så alle ser det?

Det måtte være dette som kaltes en poetisk raptus! Fingrene hans fløy over tastaturet, og han følte at han kunne ha skrevet i timevis uten å gå tom for ord.
Kjente ordene
før de kom:
Søt kiling
i magen
da de stupte
mot antennen
og slo gnister
på displayet
There aint no
cure for love.

Nå var det dr. Peter Eisbergs tur! Han kastet et hånlig blikk opp på veggen, der han visste at det håpløse evangeliet til professoren skulle befinne seg et eller annet sted. Så skrev han:
Isbreen
den kalde kjempen
var den første som pløyde landet.
Skrubbet og skurte
formet og flyttet
til solvarmen kom.
Da smeltet han
og veltet i fossen
som trollet i eventyret.
Og det nypløyde landet
løftet seg
trakk pusten
og fyltes av liv.
Nå kunne historien begynne...

Etter denne kraftanstrengelsen måtte han legge seg ned på ryggen igjen og tenke videre. Han tenkte på de første menneskene som hadde strevd seg fremover etter den smelten- 
118 de isen, på jakt etter et land de kunne kalle for sitt, et sted de kunne leve i fred og finne mat og ly for vinterstormene. Det førsteamanuensis Selfinn Tangen egentlig hadde ment å si, var at de hadde kommet til et land fullt av muligheter, selv om det var lenger nord enn noen hadde levd før dem, helt oppe under brekanten. Han hadde bare ikke klart å si det, men rotet seg inn i en lang, tullete regle med vitenskapelige forbehold og utenomsnakk om forskningshistorie som enhver besøkende ville glemme 30 sekunder etter at han hadde lest det, men som ville skremme $90 \%$ av publikum fra å lese noe i det hele tatt. Musum skrev:

De kom til et barskt land, men de sultet ikke.

I skogene sprang elg og hjort

i fjordene svømte sel og fisk.

Strender og svaberg

bugnet av skjell og snegler,

og menneskene var sterke

og kloke.

De kom til et barskt land, men de sultet ikke.

Mer var det vel ikke å si? De som ville vite mer, kunne lese en bok eller gå til undertekstene. Det svake dagslyset silte inn gjennom en liten sprekk øverst oppe i kuppelen, og røpet de vakre formene til verdenen bak utstillingselementene. En dag ville han lage en tekstutstilling, helt uten gjenstander. Telefonen vibrerte varmt mot låret hans.

Står stille her

utenfor døren

lengter.

åpner du?

Så gjorde han det.

\section{Summary}

In a playful short story the author confronts a curator and a copywriter on the ever recurring issue of the role of labels and texts in museum exhibitions. Education vs entertainment, dullness vs seduction, a conflict based on the legibility and quality of the wording. The confrontation ends in peace with the curator admitting that a lot can be learnt from the verbal economy and wit of the commercial copywriter, even from the limitations of SMS messages, in order to catch the attention and imagination of the casual visitor, thereby maybe enticing her/him to study more demanding information.

\section{Note}

- Denne novelle er skrevet som oplæg til et kursus i tekstning av utstillinger på Museumshøjskolen i Danmark, oktober 2001.

Museumsdirektør Olav Aaraas,

Adr: Norsk Folkemuseum,

Museumsvn 10

N-0287 Oslo

e-post: ola@norskfolke.museum.no 


\section{Post-Modernism and THE Three Generations of Museums}

\section{Esben Kjeldbaek}

Ten years ago visiting museums in Normandy I had an experience that keeps coming back. It was not just that the war museums in Calais and Caen were very different from each other. Rather, each seemed to represent an extreme version of how museums begin and eventually reach a sort of evolutionary peak. This difference comes to mind every time postmodern museum criticism tells me that old museums are keepers of (usually harmful) myth, and that new ones must therefore self-critically deconstruct nationalist beliefs and themselves promote humanitarian values and even repentance in general.

\section{Two War Museums}

The war museum in Calais was housed in a German communications bunker situated near the centre of the city. The bunker was partly over ground, but when you entered your first impression was the musty smell. Everywhere stood hand-painted exhibition cases teeming with objects. Second-hand mannequins wore uniforms and stared back at you with confident grins. I do not remember any stated purpose of the exhibition, but the general subject was the fate of Calais during WW II. This meant for instance also the engine of a German Messerschmitt that had happened to be shot down near the town. At the exit you could buy dud machinegun shells for five francs apiece. Coming from the un-reformed Resistance Museum in Copenhagen, I felt rather at home.
The objects in the exhibition had not yet become exclusive to the museum, but were still somehow in circulation as these machinegun shells that could be bought for the price of a postcard. You half expected an old resistance fighter to enter with a gun, place it in a show case, and perhaps paint this a better colour in the process. One had the feeling of being in a place with live roots, although, actually, I think it was the local tourist board that payed to keep the place open at all.

The new (1988) "Memorial pour la Paix" in Caen proved a strange contrast. Inside the white concrete structure of the Memorial you felt as if 50 years had passed in a flash. You were now in the huge space of an airport where ingeniously constructed exhibition cases and mock-ups stretched as far as the eye could see. At the back was an excellent café. 
120 Computer screens and film projectors showed grainy black-white film footage from the fighting in 1944, or old people recollecting. You were seing here a distant past.

Whereas the bunker exhibition in Calais seemed to be the kind of museum people make themselves to keep memorable events alive, Caen on the other hand was calling up a time already beyond living memory. And in doing so, the Memorial had another purpose than merely to document Normandy's fate during WW II. It also provided the visitors with a ready-made eyepiece through which to view the past. The "Memorial pour la Paix" officially subscribed to the ideals of The United Nations including, not least, the human rights.

It should be said that the Memorial was by far the more rewarding museum to visit. You could spend days there. Great pains had been taken to provide and present interesting objects, information in all forms was at your fingertips, the staff was helpful. And unless you were against human rights, visiting the Memorial you should feel to have carried out a sort of pilgrimage for peace and understanding.

But I still liked the bunker in Calais better.

\section{Post-Modern Criticism}

Writers in current museology would probably find that one ought to feel otherwise. Mainstream thought now holds that a Calais-type of museum is not only outdated in technical terms but even more so ideologically speaking. Many, if not all, of these "1. generation museums" can be condemned for being shaped by nationalism, imperialism, euro-centrism, blind evolutionarism, or the like.
This may be so. But, interestingly, these judgements are most often based on ideological analysis of the texts in the exhibition, the catalogue, or official statements-of-intent. Or analysis of the political, social and economic set-up behind the museum. Since very few museums actually state lies in their exhibitions, the postmodern critics focus their criticism on what is left out, or more virtuously: what is "suppressed". But language and power structure alone can hardly describe a medium which, at the core, consists of authentic three-dimensional objects placed in a space. There may be all sorts of intent (some of it unconscious) behind a given exhibition. But an important part of its effect is, what you, the visitor, actually feel and experience there. And this is what much ideological criticism, being preoccupied with the lacks, fails to explain or even note.

What then if you could show a typology of museums by viewing them from the bottomup, or, rather, from-the-entrance-in?

\section{Generations of Museums}

Trying to do this I shall return once more to Calais and Caen. If the bunker in Calais was "1. generation" then the Memorial in Caen might be called "3. generation", a grandchild rather than a child. Somewhere in between you might perhaps put the sensible and didactic type of museum - the ones so commonly shaped in the 1970 'ies - to fill out the role as an intermediary stage, a " 2 . generation".

Using this distinction as a frame for analysis, you might perhaps find that you - too have experienced some of the following differences when visiting museums: 
Type:

Arrangement

Light

Catalogue

Visible staff

Colours

Sound

Smell

Texts (form)

Texts (content)

Walking against

the direction?

Security

Fee

Setting of objects Object next to kind

Aims of arrangement Total representation, "everything important"

Perspective

Touch objects?

Rights of group

Some, some not

Sanctity of objects

Role of objects

School of literature

Way of collecting

Registration

Magazines

Initiator

Owner

Background group
Funding
Relation to History
Administration
Conservation

Proof/documentation

Positivist, traditionalist

Passive (gifts)

Donator and year

of acquisition

Stuffed

Pioneer/pioneer group

Private/Association

Friends

Money for things

Part of history

Wise person (lady)

One-type chemical,

keep the rain out

Compared to language The word

Compared to travel Your parents' grave

Employees' attitude We are a family

Reaction to criticism Silence (we know, we have enemies)

Reaction to threat

of being shut down Stupefication, determination

Enemy of concept Time

Imprint/function A monument
2. Generation museum

Planned course

Indicative

Points-to-take-home

Uniformed guards

Many, douce/dark

Surround

None, plastic paint

Print

Why (long)

You are told the right direction Guards walk rounds

Reasonable, reduction for schools

Object and text

Selective, "everything

important explained"

Rights of society

Special room

Basis for the texts

Information

Revisionist

Active collecting according to plan

Original function

Ordered, climate-control

Reformer

Public, Large corporation

Association of friends

Money for staff

Represents history

Skilled ladies, male boss

Skilled, planned, growing

Functions of words,

the clause

charter-trip

We are professionals

Refutation in report

Demand for job security

Obligations

Official opinion
3. Generation museum

Scenographic

Aesthetic

Essays and advertisements

Actors, focus-group solicitors

Few, stark

Videos

Coffee

IT-screen

Choose

No particular direction

High-tec

What the market will bear

Surprise

Details of episodes

and individuals

Rights of individual

Special room for children

Holy (until exhibition

is changed)

Fascination

Post-modern, de-constructive

Bought/hired/loaned

History of reception

Whole collection is on show Conceptualist, entrepreneur

Public Agency/Self-sustaining business

Sponsors

Money for events/projects

What it means to the curator

Equal and pursuing a carreer

Selected objects, TV-event

when it happens

The text: what could

it mean?

Survival tour with correct

implements

We're great

Media management

Develop new concept

Expectations

Current trend 
122 Now, viewing the properties of the generations from the top down it should be possible to get a little closer to the qualities of each one.

\section{The i. Generation Museum}

The 1. generation museum might have "personal" as its keyword. It is founded to celebrate a victory won or wealth acquired, by a person or by a class. Examples from Denmark might be the Rosenborg Castle (the Oldenborg kings from 17th to 19th Century), The Open Air Museum (Following the political breakthrough around 1900 of the farming class), The Museum of Danish Resistance 1940-1945 (Summer of 1945) or the Workers' Museum (Founded by the Danish Trade Union Movement in 1971), all in or near Copenhagen.

The outlook of the 1 . generation museum is of its nature partisan. It is tied to its founders almost to the point of being a part of them.

Most 1. generation museums eventually change into a 2. generation form (see below). But if the external and internal demands for modernization can be suppressed one of three things may happen. The museum may simply be closed down for lack of relevance, but this almost never happens. If it can refine its best "1. generation characteristics" (for instance the rarity of its objects) it may go on as before eventually reaching the position of being Heritage. This has happened to the Rosenborg Castle, which e.g. exhibits the Danish crown jewels. No one now seriously expects Rosenborg to mention the suppressed copyholders who payed for them.

The third (but very rare) possible role for an un-reformed 1 . generation museum is that of a Cult-museum, that is a museum so out- dated that it still faithfully reflects a now defunct culture or mind-set. Until its removal in 1967 the old Copenhagen Zoological Museum was such a museum. Crammed in everywhere you might find rows upon rows of specimens in glasses with alcohol, brought home from foreign countries at the cost of lives and meticulously marked with unreadable labels. Some still regret that it is no longer there.

But the Cult-status is not something that can be reached by design. It has to sincerely represent a genuine but now failed effort of understanding the world.

\section{The 2. Generation Museum}

The 2. generation museum may have "education" as its catch-phrase. They are developed from - and usually in opposition to - a 1 . generation form. Every 2. generation museum has somewhere in its history a fierce battle between the founders and the reformers, won by the latter, who (guiltily) take pleasure in finally doing away with the outdated or outrightly false statements in the 1 . generation exhibition. But they also represent the attractive belief that History can be learned, Man can be educated and that society can profit from it. They are therefore also the type of museum that most openly state a purpose. This, however, does not necessarily prevent them from being as one-eyed, or propagandistic as the 1. generation museums. The museums in the old East-Bloc usually had the properties listed above under 2 . generation.

In any case the assumption that people visit museums in order to be taught is probably wrong. Professionals and students may do, but the general public in a free society has a whole range of other reasons than education when 
they enter museums, curiosity perhaps being the most important one.

The 2. generation museum is an unstable type. Whereas the 1 . generation museum is basically satisfied with itself as it is, and is ready to live on a stone, the 2 . generation museum has a built-in propensity to expand. There is no real limit to the amount of objects it will collect or the costs it will claim to conserve them. The exhibition, which seldom recognizes the emotional needs of the guests, tends to be stale, because it has much fewer objects than a 1. generation museum. It uses them merely as a means that could ideally be replaced simply by a text. This disregard for the powers of the object will lead to the loss of visitors, a loss that can seldom be made up for by the forcibly enrolled school-pupils. It is probably no coincidence that the 2 . generation museum is usually to be found in states that are, or aspire to be welfare states. And like the welfare state the 2 . generation museum is threatened and in the end perhaps felled by the pressures on its economy. The state or large corporation that supports it demands a better return on its money in terms of visitors, exhibitions, arrangements and media exposure. It must change into a 3. generation museum.

\section{The 3. Generation Museum}

The 3. generation museum is post-modern. The properties, I have listed above are, of course, something of a caricature. In reality a 3 . generation museum might (like the Memorial in Caen) incorporate many of the qualities of the 2. generation museum. Actually there may not exist a "pure" 3. generation museum anywhere yet. But on the other hand one can see it developing in our present museums.
In theory a 3. generation museum may have 123 no roots in a former museum. But in that case, as a wholly new venture, it might prefer to take the shape of a "Theme Park", which is hardly a museum at all. Usually a 3 . generation museum will be a reformed 2. generation museum. It will have learned an important lesson from the failed parent: museums are about objects, not texts. The 3 . generation museum will take great pains to procure just the right objects. There are several reasons for this. The first is that modern media in its rapid expansion has failed to expand its credibility as well. Perhaps even the reverse has happened. News, History, the Internet all exist on just a screen, where they compete for attention.

Against this background objects of proven authenticity have now begun to carry more weight as elements in the communication of the past. A simple, functional cause for this is that the museum medium with its spatially placed objects can be accessed in much the same way you use a computer: from any side and instantaneously. You can look at an object, pass it by or return to it, the choice is "digital". In this sense the museum is different from the book, the film, the song or the tale who are all "analog" and must be digested from one end to the other. But the museum combines this zap-quality with a tactility, a feeling of direct access to the past, that the electronic screen simply lacks.

There is, however, another reason for the new role of the authentic object. Postmodernism sometimes claims that the means of communication - the "text" - itself constructs the reality it wants to convey. All the phenomena around us do not really exist until they have been formulated as a text ("text" being also other media than the written one). But 
124 any statement, any text, it is argued, is also always a statement from some position, a special interest, and thus a text can always be attacked - in fact: must be attacked - for its hidden agenda and the things it leaves unsaid. Taken in its literal meaning this puts the museum text writer in a difficult position. It seems she is suddenly burdened with actually creating the past, and, not being God, she prefers to step back and "let the object speak for itself". Therefore some museum exhibitions of the 90s have this anemic, almost barren look, where the curator seems to have simply vanished, and where it has been left to the architect or some invited artist to create a meaning. But this means also that the lasting impression of the museum visitor may end up being the fire-extinguisher on the wall because it had both an understandable purpose and an understandable text.

The 3. generation museum, being a business, is more dependent upon its visitors than the older forms. If the public in this last decade has been searching for fixed values to believe in, the 3 . generation museum must try to answer the need. It does so partly by the cult around its objects, partly by infusing its exhibition and arrangement with a moralistic angle. Anything that smacks of nationalism, racism, sexism etc. is avoided if not outright condemned. Equality and human rights are stressed. If asked, the 3. generation museum can also show that it has internal programs for equal rights, hiring of minorities and perhaps a policy dealing with the problems of the old or the drunk in its staff.

But this platform has a serious weakness. If the attitudes of the public and the economic climate changes, the 3 . generation museum must go along. It is for instance unlikely that nationalism will return in its old form.
But a museum that now promotes international values over national ones, may one day find itself forced to cater instead to regionalism, because its customers have begun to react in this way against "globalization". And so forth.

\section{WHAT IS WRONG WITH}

\section{the 3. Generation Museum?}

If at least some of what has been said above is correct, then I can also partly answer the question that puzzled me 10 years ago i Normandy.

Spending time in a 3. generation museum is not challenging, it is comfortable. But at the same time you are not quite certain that you are really in a museum. Much of what you see is the same as in the Mall you just left outside. The videos, the café, the museum shop, the service or the string-quartet. Even the objects - although coming from very interesting places - are in a sense matched by the Rolex'es and Ferraris in the Mall and protected by the same kind of security glass.

Why is it that you want to escape from all this and dive down in some old 1. generation museum in stead? Why are biased and outdated museums emotionally superior to the ones that belong to your own time and seems to reflect your life-style and values?

In the first place a good deal of our values, especially the ones that are promoted from above, are always partly false.

The central modern value is the right of the individual, and - with yesterday's heroes and ideologies gone - postmodernism has tended use the plight of the victim as the most telling contrast. The victim has become the protagonist in much historical research and international reporting. But after the fall of 
the Iron Curtain, an important component in human rights has disappeared from view: the fact that rights have not historically been bestowed from above. They have been fought for. And battles, being social and collective enterprises, demand discipline and subordination of the participants, or in a word: sacrifice. Official modern culture no longer seems to be aware of how human rights came to be a value at all. Therefore the museum of the future might be one that combines vague universalist ideals with a deconstruction of the past, and an added opportunity to be a consumer while taking this in.

The point is: would you visit such a museum yourself?

\section{How SHOULd A MUSEUM FUNCTION?}

To the modern museum an escape into tribalism or nostalgia is not desirable or even possible. But the new combination of aestheticism, moralism and the market is hardly more attractive. Perhaps as a beginning something is to be learnt from two of the qualities of the 1 . generation museum.

Here the object basically is a trophy from some great quest of which it is both a result and a proof. Later generations may prefer to use objects to inform the visitors or to fascinate them. But these functions, I suggest, are derived from the original use and cannot stand alone. What good is disinterested collection of information or uninformed fascination? And how could the museum media either inform or fascinate, if there were no real objects?

The authentic object should be respected for its infinite possibilities as an actual part of the past. This sets it apart from the model or the replica. Most people would instinctively 125 reject an exhibition consisting only of models or replicas, or wouldn't go there more than once.

\section{WHY?}

The model may be beautifully made up, exciting, and instructive. Being three-dimensional it is also tactile and can play the part of an object as opposed to the pictures got up on the electronic screen. The model contains a maximum of information - but as a material relic it only points back to the workshop of the model-wright, his dexterity, the types of glue he used, and the knowledge of the mind that planned the model. But then knowledge is important? Why not fill the museums with models?

The model is explanatory and in a wider sense the illustration of a world-view - but in it you can only find what the maker ("the teacher") put there. It constantly empties itself of the information it contains, but has little more to offer. Its limits are clear. And the same goes for the replica. It can never contain more than its maker at a given time saw, understood and was able to reproduce in his copy.

The model is authoritarian. Spritually you are standing down there, somehow looking up at the model and its maker.

But is the authentic object then in-finite and anti-authoritarian? I think so. As any museum-person knows, an object may always turn out to be something different from what we thought it was. Or circumstances may force us to interpret it in new ways. Or it may reveal information that no one "put there", but that we are happy to have suddenly discovered. So, as opposed to the model or the 
126 replica, the authentic object can itself grow in the process of giving off information. This means that we can never be entirely sure about the texts we pin to our objects. They may one day blow up in our faces. And this is what the public senses. Spritually the curators must accept to stand shoulder-to-shoulder with the public in front of the authentic object. Because in the end you never know the final interpretation of the past that it is a manifest part of.

The object, therefore, is potentially subversive.

And this connects to a second 1.-generation-quality. That of attitude. The founders of the 1 . generation museum will of course feel certain that their explanations and use of their objects are self-evidently right.

But basically the 1 . generation museum is a place where strangers from the past want to show you something important. To them. The purpose of the whole institution is to convince you of their importance and right to a place in the world. They are, as it were, showing you their wounds as well as their achievements. But in doing this, they treat you as an equal, because, after all, this is the only way of genuine persuasion.

And this makes you feel good.

Thus the qualities of our museum-grandfathers are that they chose to document their own past by unashamedly putting objects from it on view. And that in doing so they created a medium that can - potentially transcend some of the barriers that divide us from them and, perhaps, us from each other.

\section{Notes}

- A previous version of the text has been published in Danish: Esben Kjeldbæk: Ting fra besættelsen, s. 359-
93, in: Dethlefsen og Lundbak (red.): Fra mellemkrigstid til efterkrigstid. (1998)

1. In the following the Memorial in Caen is no longer the concrete model of "the 3. generation museum".

2. The director of Rosenborg Castle once said that of all the Copenhagen museums he felt the closest likeness to the Workers' Museum. And quite right: both basically communicate by showing authentic interiors of dwellings. Time will show, if the Workers' Museum can keep going as long as Rosenborg.

3. But if the economy calls for less spending, staff will get the axe, no questions asked. Conversely, the 1 . generation museum might fire persons who do not support its concept, but will try to keep on staff, that are endangered by mere economy.

Esben Kjaldbak is Curator of The Museum of Danish Resistance 1940-1945 (Fribedsmuseet).

Adr: Churchillparken, DK-1263 Koebenhavn K.

Fax: +45-33140314.

E-mail: esben.kjeldbak@natmus.dk 


\section{SAMTIDSDOKUMENTASJON: EN SPØKELSESHISTORIE}

\section{Odd Are Berkaak}

La meg begynne med a problematisere de to sentrale begrepene samtid og dokumentasjon. Som vi alle er enige om, kan disse kategoriene forstås eller anvendes på flere måter. Det knytter seg betydelige metodologiske og teoretiske konsekvenser til ulike måte å definere dem på. Jeg vil derfor forst se litt på hvilke betydninger som ligger skjult $i$ disse begrepene, som en ideologisk arv innenfor vair kunnskapstradisjon.

For å ta det siste først: Til begrepet dokumentasjon knytter det seg tre føringer som ofte styrer vår praksis på området. Det første av disse er uoppsettelighet - dokumentasjon er en hastesak. I mitt fag snakker vi om 'urgent anthropology' når det gjelder beskrivelsen av samfunns- og kulturformer som er i ferd med å forsvinne. De må dokumenteres før det er for sent. Det har ligget i sakens natur at de formene som oppfattes som mest alderdommelige må beskrives først, og så får vi ta de mer moderniserte etter hvert. De er jo her i alle fall, tenker vi. Vi har en forestilling om at noen kulturformer eller gjenstandsgrupper er på vei ut av historien, omtrent som truede arter, mens andre nærmest er å forstå som ugress. Denne redningstanken har begrunnet virksomheten ved de etnografiske og kulturhistoriske museene verden over i mer enn hundre år.

En slik konstruksjon av vår virksomhet henger sammen med et syn på tid som en elv hvor nye gjenstandstyper kommer flommen- de inn i historien for i neste øyeblikk å strømme ut igjen. 'Det nye' presser ut 'det gamle'. Dette er modernitetens og markedets tidsbegrep. Det er tiden delt i tre faser: forventningens horisont, det trivielle nået og den tapte fortid. I dette scenariet står antikvaren nede i elva med et garn hvor maskevidden er slik at alle verneverdige ting fanges opp (reddes) før de går i fossen.

Den andre forestillingen som hefter ved dokumentasjon er annerledeshet. Vi dokumenterer det som er relativt ukjent, unikt og ekstraordinært. Som alle gode samlere er vi mer interessert i det vi mangler $\mathrm{i}$ herbariet eller frimerkealbumet enn det vi allerede har sikret oss eksemplarer av. I dagens situasjon er det betydelig vanskeligere å skaffe midler til å dokumentere en 1996 modell Toyota Corolla $1300 \mathrm{ccm}$ stasjonsvogn enn en seilende råseiljekt (selv om det kan være vanskelig nok). Denne meningsdimensjonen ved begrepet dokumentasjon styrer vår oppmerksomhet bort fra det samtidige, det som er her. Vi fa- 
128 voriserer det ekstraordinære og alderdommelige.

Den tredje forestillingen som skjuler seg i begrepet er klassifikasjon. Opplysningstidens og Victoriatidens samlere var preget av Linnés ideal om at verden lot seg fange og beskrive som et logisk system av objektive forskjeller. De fleste museer i dag har fortsatt et skjema - elektronisk eller fysisk - som skal 'fylles ut' for hver gjenstand. Denne skjematiske representasjonen av gjenstanden føres deretter inn i en 'katalog' hvor de ordnes taksonomisk i forhold til region, bruk, form, materiale eller andre klassifikatoriske trekk. I dette rasjonalistiske scenariet ligger naturligvis også troen på det objektive. Dokumentasjon er for de fleste en faktisk beskrivelse som skiller seg fra 'analyse' og 'tolkning' på den måten at den bare 'sikrer' materialet uten å forandre det. Den så og si fryser objektene og konserverer dem slik at forskeren kan analysere og fortolke dem etterpå.

Til slutt ligger det i en slik klassifikatorisk praksis at tingene har en endelig og avsluttet form. Man kan ikke føre noe 'halvferdig' inn $i$ et herbarium ganske enkelt fordi embryoer ikke kan ordnes i en endelig klassifikasjon og klassifikasjon skal være endelig. En embryo vil fortsette å forandre seg og derfor skape rot i systemet. Som svar på dette sier vi ofte at samtiden ikke kan beskrives før i ettertid - når den har 'funnet sin form'. Hvis man dokumenterer noe som er i endring, innebærer det bare at man må gjenta dokumentasjonen og fortsette å reklassifisere fenomenet (helt til det ikke endrer seg lenger).

Når det gjelder det andre begrepet -samtid - er det betydelig mer komplisert å avklare. La meg likevel foreslå noen distinksjoner som kan skape litt mer orden i begrepsbruken.

For det første kan man si at samtid er et tidsutsnitt - en epoke. Man kan for eksempel bestemme seg for at samtidskulturen er 'det 20. århundre'. Et slikt grep er helt i tråd med den innarbeidede akademiske praksis som uttrykkes i slagordet 'Minervas ugle flyr om aftenen'. Flere forskere har pekt på det faktum at den kulturhistoriske forskning omkring et fenomen sjelden kommer i gang før forskningsobjektet er i ferd med å forsvinne. Ernst Gellner (Gellner 1983) viste for eksempel at den vitenskapelige interessen for nasjonalismen og nasjonalstaten oppsto først da epoken var på hell. Ikke før andre politiske institusjoner og identitetsformer for alvor begynte å utfordre nasjonen, våknet historikerne og sosiologene.

Det er først og fremst tre typer problemer forbundet med å tenke samtid som epoke. For det første er det alltid slik at en epoke inneholder et uendelig antall fenomener som ikke er typiske for epoken. Det dreier seg om gjenstandstyper, organisasjonsformer og kulturelementer i sin alminnelighet som eksisterte lenge før epoken tok form. Slik forekom det for eksempel under barokken en uendelig mengde ting som ikke var barokke, på samme måten som det i det moderne eksisterer en mengde 'umoderne' ting. Det er derfor nødvendig med tilleggskriterier for å skille ut hva som er samtidig i en slik epoke, det gir seg ikke selv.

Det andre problemet som hefter ved avgrensninger $\mathrm{i}$ epoker dreier seg om at det materialet avgrensningen resulterer i blir for upresist og uhåndterlig. 'Det 20. århundrets kultur' er for eksempel alt for omfattende til å la seg operasjonalisere innenfor de ressursrammene et forskningsprosjekt gir. Det blir derfor igjen nødvendig å koble inn sekundære avgrensningskriterier som blir viktigere og mer interessante å diskutere enn samtidskri- 
teriet i seg selv. Hvis vi for eksempel sier at de arkeologiske utgravningene som for tiden pågår i Kaupangen, og mobiltelefonbruken blant ungdom på Oslo indre øst er samtidige fenomener, så blir avgrensningsproblemet tydelig. Det er ikke naturlig å si at funnene i Kaupangen er samtidsdokumentasjon, mens undersøkelser om mobilbruk opplagt vil være det. Det er ikke desto mindre et like ubestridelig faktum at disse fenomenene eksisterer samtidig. Det er med andre ord igjen noen helt avgjørende tilleggskriterier som gjør at vi velger mobiltelefonien fremfor vikingbyen når vi snakker om samtid.

Dette eksemplet viser imidlertid også at samtidsdokumentasjon er en pågående og ikke avsluttet prosess. For selv om vikingbyen som graves frem er historisk, så er selve utgravningen og de verdier som ligger til grunn for den, samtidige. Man har i generasjoner vært klar over at det lå en tidlig middelalderby på stedet, men det er først på 1990tallet at begrunnelsene for å sette inn ressurser for å avdekke den har fått politisk gjennomslag. Selve utgravningsprosjektet er således samtidskultur selv om de fysiske funnene som gjøres er spor av forgangen virksomhet.

Det tredje problemet er at man lett kommer til å studere fortiden isteden for samtiden. Å avgrense en epoke vil si å sette et tidsutsnitt i parentes og behandle det som om det var et avsluttet hele. $\AA$ si at samtid er 'det 20. århundre' er et eksempel som viser dette med all tydelighet. Under en slik avgrensning vil man med den største selvfølgelighet kunne studere stumfilm, bygdefunkis og propelldrevne jagerfly. Alle sammen fenomener som det er viktig å utforske, men det er urimelig å kalle dem samtidskultur flere generasjoner etter at de gikk ut av bruk. Vi bør ha et samtidsbegrep som ikke inkluderer foreldede ting.
En helt annen måte å avgrense samtid på er å si at det er et gjenstandsområde. Da kan vi for det første si at det samtidige er det vi ser når vi ser $u t$ av vinduet. Det dreier seg rett og slett om den verden av gjenstander som omgir oss akkurat nå, altså både gammelt og nytt, likt og ulikt. Problemet med en slik avgrensning er naturligvis at det ikke er en avgrensning. Man kan kort og godt ikke dokumentere 'alt'. Selv ikke den franske litterære bevegelsen le noveau roman, med Robbes-Grillet, Butor og Simon i spissen, maktet det, selv om gudene skal vite at de forsøkte!

Man kan imidlertid innsnevre gjenstandsområdet ved å si at det samtidige kun omfatter de formene som er i ferd med å dannes her og nå, og som derfor (i ettertid) vil bli typiske for denne tiden. Det er det jeg andre steder har kalt 'det påbegynte' og som i engelskspråklige kulturstudier gjerne omtales som "emerging culture" (Berkaak og Ruud 1992). Dette er i tråd med modernitetstenkningen hos f.eks. Habermas, som sier at det moderne er perioden etter den kristne middelalder hvor samtiden viderefører bruddet med fortiden i form av en stadig pågående fornyelse. (Habermas 1987) Ernst Bloch formulerer begrepet "Das noch-nicht Seins" for den samme tanken. (Bloch 1986; se også Garnes 1995) 'Det ennå-ikke værende', som vi med et godt norsk uttrykk kan kalle 'det som er i kjømda', karakteriseres ved at det er i verden, men ikke i språket. Det eksisterer, men er uten referanse. Vi kan erfare det, men ikke benevne eller klassifisere det. Det er med andre ord litt skummell - eller spennende, alt etter som.

Disse filosofiske betraktningene peker rett mot de fenomenene vi er ute etter å fange. Det gjelder for eksempel motetrender som er så 'hotte' og så 'cutting edge' at selv om vi har tatt dem i bruk og praktiserer dem, ikke har 
130 oppnådd enighet om hvordan de skal vurderes og innpasses $\mathrm{i}$ forhold til resten av vårt kulturelle repertoar. Vi kan her også tenke på eksotiske menyer som er på rask innmarsj i den norske middelklassedietten, men som vi ikke helt har fătt opparbeidet rutiner i forhold til. Vi er ikke helt sikre på hvordan vi skal bruke pestoen og parmesanen og all den indiske guggemeien med flammekrydder. Vi vet ikke helt hva vi gjør, med andre ord, men med Bourdieu kan vi si at det er nettopp derfor det vi gjør blir så spennende. Vi prøver oss frem, kikker litt på hva venner og bekjente gjør og leser litt i blader og kokebøker. Men det blir nok ikke orden på tingene før om et tiår eller så. Slike ting kan vi med Bloch kalle mulige, men ikke faktiske praksiser.

Det man vinner ved å avgrense samtidsfenomener på denne måten, er at man blir sittende igjen med et metodisk håndterbart materialtilfang. Man vil i det minste vite hvor man skal lete og hvilke karakteristika man skal se etter. Samtidig (oops!) har det den styrken at det systematisk peker ut de fenomenene som er typiske for samtiden. Vi vil imidlertid stå overfor det problemet at de ikke uten videre lar seg bestemme med de tradisjonelle metodene vi anvender i dokumentasjon. De vil støte mot flere av de innarbeidede føringene som ligger i vår dokumentasjonspraksis slik jeg forsøkte å skissere det foran. Historisk nye ting vil for eksempel ikke oppfattes som hastesaker. Tvert imot vil man kunne innvende at vi må vente til de har funnet sin endelige form. Kan hende er de bare 'døgnfluer' og dermed kulturhistorisk uinteressante, vil noen hevde.

Det største problemet vil likevel oppstå i forhold til klassifikasjon. Nye ting er rett og slett ikke klassifiserbare før de har fătt entydige betegnelser, praksiser og forståelser knyt- tet til seg. Linné plukket ikke knopper. De vil heller ikke oppleves som objektivt gitt ennå. Mange vil være svært skeptiske til dem, mens andre kanskje vil anse dem som selve redningen for menneskeheten. Det vil på tidlige stadier stå strid om hva en gjenstandstype betyr, hva den skal brukes til og om den overhodet har noen funksjon. Er det bare et leketøy, eller kanskje er det til og med et onde? Hva skal dokumenteres? Hvilke praksiser skal for eksempel et redskap beskrives i forhold til hvis det ennå ikke har etablert seg en ensartet bruksmåte? Hvor er konteksten? Hvordan skal en stakkars innsamler klassifisere noe som ennå ikke er klassifisert blant brukerne?

Det vi snakker om her er det man i samfunnsfagene kaller institusjonalisering. Den korte eller lange prosessen som utspiller seg fra et nytt element introduseres til det er oppnådd enighet om hvordan det skal betegnes (klassifikasjon), hvordan man skal handle $\mathrm{i}$ forhold til det (konvensjon) og hvilken betydning eller moralsk verdi det har for fellesskapet. Vi kan for eksempel tenke oss innføringen av kaffen i Norge. I den helt tidlige perioden visste man ikke en gang hvordan den skulle fortæres - som suppe eller drikk. Noe liknende vet vi var tilfellet med poteten. Etter hvert vet vi alle sammen at de har inngått som de viktigste (og mest selvfølgelige) ingredienser i vår meny.

Med et begrep fra lingvistikken kan vi kalle det leksikalisering (meningsdanning). Man forestiller seg da en historisk ny erfaring eller et nytt fenomen som en befolkning på et gitt tidspunkt blir konfrontert med. Til å begynne med vil de være 'stumme', dvs. at man rett og slett ikke har noe ord for dem. De vil være uten referanse, som Bloch sier. På det tidspunktet kan vi sammenlikne slike fenomener med spøkelser eller zombier - levende 
døde. De er i blant oss, men har ingen identifiserbar form. De er født, men ikke døpt (og slett ikke konfirmert).

Snart vil det imidlertid komme forslag til betegnelser. I en overgangsperiode vil det eksistere flere konkurrerende betegnelser, men etterhvert vil én av dem bli oppfattet av flere og flere som mest dekkende. Til slutt vil det vokse frem en alminnelig konsensus omkring fenomenet, og betegnelsen vil føres inn i ordboka med en entydig mening. Den vil dermed ha fått en autorisert referanse og så og si bli 'satt ut i livet'. Alle de andre tolknings-og praksisforslagene som var en del av den samtidige diskursen, men som ikke ble representert, vil fortsette å 'spøke' i krokene som halvkvedete viser og ekko av navnløse minner. Her kan vi for eksempel tenke på et fenomen som 'samboerskap'. Det er i dag et godt innarbeidet og rimelig entydig begrep. Det er også en akseptert praksis med helt spesifikke juridiske bestemmelser knyttet til seg. Det er imidlertid ikke mer enn en generasjon siden at det var nesten helt ukjent og uhørt. Betegnelsene var da moralsk negative, slik som for eksempel 'å leve i synd'. Alle de forskjellige måtene å bo sammen på som ble praktisert og forsøkt fra midten av 1960-tallet frem til årtusenskiftet, men ikke institusjonalisert, vil en tid klinge med som et ekko i form av private minner, bitre hint og halvkvedete viser. Snart vil de gå i glemmeboka eller havne som kuriosa på roteloftet. De er en viktig del av det forgangne, men ikke av historien - levende døde.

Vi kan tenke oss utallige andre eksempler på tilsvarende forhold i det senmoderne samfunnet. I Norge er et opplagt eksempel hele den samfunnsendringen som har fulgt i kjølvannet av oljeindustrien. Her er alle de løsningene som $i k k e$ ble valgt like viktig å doku- mentere som de vellykkede, fordi de danner en kontekst og tolkningsramme for å forstå de beslutningene som faktisk ble tatt. Her har konservatoren ennå tid til å agere som 'ghost buster' - få dem ut av skapet, som det heter. Andre gode eksempler er innføringen av ITteknologien, eller utviklingen av nye carbonmaterialer. Bruken av disse materialene medfører en revolusjon innen byggebransjen. Det samme skjer hver dag på motemarkedet hvor nye stilformer kommer og går i rask rekkefølge. Mange er kallet, men få er utvalgt. Hele fritidsmarkedet er et annet område som viser de samme trekkene. Tenk bare på innføringen av 'snowboard', 'bigfoot' og 'snowblades' o.l., og hvordan dette har ført til endringer og strid om hva som er 'riktig' form for skiløping. I løpet av neste generasjon er dette trolig også innarbeidede og selvfølgelige ting med konvensjonelle praksiser knyttet til seg. Alle de 'mislykkede' prosjektene, de som ikke slapp inn i varmen (dvs. markedet), vil fortsette å flakke referanseløst omkring på mørkeloftet som urealiserte muligheter. Uha!

Så kan det innvendes at det nettopp er på grunn av slike forhold at dokumentasjon, klassifikasjon og museal innsamling bør vente til disse fenomenene har 'funnet sin form', som det heter. Mitt argument er imidlertid at hvis man følger slike prosesser mens de er i kjøm$\mathrm{da}$, vil dokumentasjonen ikke bare bli mye rikere, men dessuten kunne fange opp ting som ikke lar seg rekonstruere i ettertid. Hvis man dokumenterer de urealiserte mulighetene, mens de fortsatt er realiserbare, vil de jo nettopp $f a ̊$ en referanse og dermed slutte å 'spøke'. Dokumentasjonen vil være selve denne referansen som forskeren vil gi dem slik at de kan pekes på, omtales og refereres til og dermed inngå i den videre diskursen.

Det jeg her sikter mot har sikkert mange 
132 allerede gjenkjent som en diskursanalytisk tilnærming, og det er helt riktig. Det vil si at man følger - og dokumenterer - hele Den store samtalen som utspiller seg omkring en endringsprosess mens den er i ferd med å skje. Min påstand er at mange av disse 'stemmene' ikke ytrer seg i dokumentform. De ytrer seg i muntlig form i private eller lokale rom. For eksempel var det de færreste mennesker i Norge som ytret seg offentlig i aviser eller andre 'dokumenterbare' formater om papirløse ekteskap og samboerskap, men de aller fleste hadde meninger om det. Her kommer vi derfor til et kjernepunkt: den tolkningsvariasjonen som eksisterer i utgangspunktet, vil etterhvert som leksikaliseringsprosessen skrider frem bli redusert til et minimum. Til slutt er det i prinsippet bare én autorisert tolkning igjen. I ordinær historieskriving er det denne som dokumenteres og, som vi sier, 'går over i historien'. Det har på samme måte vært en tendens i norsk kulturminnevern til at det er denne 'autoriserte' varianten antikvaren fanger i sitt garn.

Grafisk kan vi fremstille slike prosesser på denne måten.

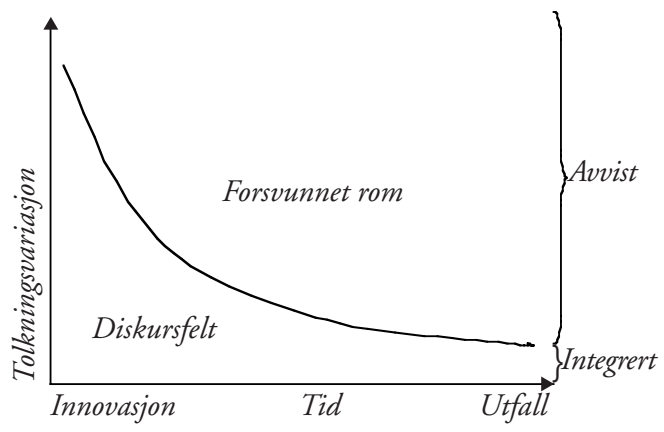

Fig.1 Leksikaliseringsprosessen
Som figuren forsøker å antyde er tolkningsvariasjonen svært rik og mangfoldig på inngangstidspunktet, i det øyeblikket fenomenet dukker opp over horisonten, symbolisert ved den loddrette linjen til venstre. Ettersom leksikaliseringen løper over tid, reduseres denne variasjonen i prinsippet til én variant. Dette kommer til syne i utfallsrommet (som det heter på statistisk), symbolisert ved den stiplede linjen til høyre. Hvis historien bare skal avleses i dette utfallsrommet, vil man med andre ord kunne komme til å se bort fra hele den diskursen som ledet frem til nettopp dette utfallet. Da ser man samtidig bort fra alt det materialet som kan sette oss på sporet av arrakene til at bestemte former etablerer seg på bekostning av andre. Man vil da også frata seg selv muligheten til å kunne forklare det samme utfallet. Ikke minst går man da glipp av den konteksten som er nødvendig for å fortolke den endelige formen. De maktforholdene, de ulike interesser og alternative argumenter og begrunnelser som gjorde seg gjeldende i leksikaliseringsprosessen, vil forsvinne ut av syne og bare den endelige formen bli igjen. For å gjøre dette kjernepunktet helt tydelig: Det er de løsningene som velges bort som i ettertid kan forklare de løsningene som velges inn. Vi kan ikke forklare historiske forløp og utviklingslinjer hvis vi ikke kjenner de alternative løpene og mislykkede formvariasjonene. De blir i så fall historieløse, og det er vel neppe målet med dokumentasjonsarbeidet.

Men dette materialet er flyktig. Det må fanges i flukten. Slik som jeg forsøker å indikere med det feltet i figuren som jeg kaller det stumme rommet. De erfaringene og ytringene og objektene som utspiller seg her 'forstummer' idet de skyves ut av leksikaliseringsprosessen. De vil forbli uten representasjon i 
tradisjonen. Det er dette jeg kaller kulturhistoriske spøkelser fordi de billedlig talt er levende døde, som zombier eller som Ernst Bloch sier: 'ikke værende'. Fordi de er uten representasjon vil sporene etter dem forsvinne og gjøre dem usynlige. Det som gjør dokumentasjon prekær i denne sammenheng er derfor ikke at de er på vei ut av historien, men tvert imot at de på en måte ikke har kommet inn $i$ historien. Redningsarbeidet i forhold til slike spøkelser er derfor like uoppsettelig, men må begrunnes på helt annet vis. Dokumentasjon av slikt materiale vil innebære at man løfter det frem fra skyggene, synliggjør det og setter navn på det, i steden for bare passivt å registrere allerede klassifisert materiale. Det vil således være en aktiv og ikke en reaktiv dokumentasjon.

Derfor berører denne diskusjonen også forskerens og forskningens rolle i samfunnet. Det er opplagt at det kulturpolitisk sett er en helt annen type handling å dokumentere objekter som allerede er en del av en kanon (ikke lenger kontroversielle), enn å bruke ressurser på 'nymotens fjas'. Sånt noe blir ofte sett på med den største mistro og til og med fordømmelse, spesielt fra elfensbenstårnet. Man kan for eksempel ofte høre at det nye er kommersielt, populistisk, vulgært osv. For tretti år siden var for eksempel ikke fotball en naturlig del av kulturforskningens ansvarsfelt, for tyve år siden var rock 'n' roll nærmest utenkelig som tema, for ti år siden var en interesse for computerspill en belastning for karrieren og $\mathrm{i}$ dag er reality-TV ytterst mistenkelig. En så høyverdig aktivitet som forskning bør befatte seg med edlere ting. Jeg kan imidlertid vanskelig se en mer verdig oppgave for kulturforskningen enn å bidra til de meningsdannende debattene omkring historisk nye teknologier, ideologier og praksiser som stadig griper inn og omformer vår hverdag. Slik dokumenta133 sjon vil være med å sette navn på nye virkeligheter og dermed også utforme dem. Det vil innebære å tilegne seg det nye, og gjøre det til sitt, isteden for å bidra til økt fremmedgjøring og nostalgi.

På denne bakgrunn er det etter min mening flere gode argumenter for å dokumentere noe som er på vei inn i historien enn det som er på vei ut. Hvis vi kan presse sammenlikningen med historiens elv og antikvaren som garnfisker enda litt videre, kan vi si at vi heller bør 'beite på oppstrøm' isteden for å forsøke å hale i land restene nedstrøms. Hastverket gjelder altså ikke det gamle, men det nye, det som ennå ikke er og som vil forbli referanseløst hvis vi ikke belyser det og setter navn på det. Spørsmålet er om dokumentasjon skal fungere som fødselshjelp eller begravelsesbyrå. Som sagt utfolder det meste av den kulturhistoriske diskursen seg utenfor dokumenterbare rom og medier, og vil derfor forstumme når diskursen er avsluttet og synspunktene (interessene) ikke lenger hevdes. Av samme grunn er det meste av dette materialet ikke rekonstruerbart. I mine fiskerimetaforer vil det rett og slett være vann. Man vil med andre ord ikke kunne fange det opp med garnet nede i elva selv om man bruker aldri så fin maskevidde. Det bør derfor være en viktigere oppgave for samtidsdokumentasjonen å bringe slike kulturhistoriske zombier tilbake til livet (historien), enn å reise stadig nye gravmæler over fenomener som allerede har fått sine monumenter.

\section{SUMMARY}

The author first makes an attempt to deconstruct the notion of 'samtidsdokumentasjon' (documentation of contemporary culture). He shows how the different 
134 ideological layers in the theory and practice of museal

Odd Are Berkaak

and archival 'documentation' tend to disregard those Adr: Institutt for sosialantropologi elements of contemporary culture that are new and Universitetet i Oslo emerging. Ernst Bloch's concept of 'Das noch-nicht e-post: oddare@uio-pop.uio.no Seins' ('the not-yet in being') is used to argue for a new focus in contemporary documentation. Those elements of our current environment which are coming into being and taking shape right before our eyes deserve our attention because the ephemeral discourse that surrounds them will not be retrievable in the future. Thus, essential material for the understanding of our own time will be lost. The conclusion is that it is urgent to document novelties, not monuments, because if they are not documented in the making, they will be lost to history for ever.

\section{Note}

- Dette innlegget ble holdt under et seminar om mål og problemstillinger ved samtidsdokumentasjon, 16. oktober 2001. Seminaret ble arrangert av Sekretariatet for samtidsdokumentasjon og -forskning, Maihaugen.

\section{REFERANSER}

Bloch, E. (1986) The Principle of Hope. Oxford: Blackwell.

Habermas, J. (1987) The Philosophical Discourse of Modernity: Twelve Lectures. Cambridge: Polity Press.

Gellner, E. (1983) Nations and Nationalism. Oxford: Basil Blackwell.

Berkaak, O.A., E. Ruud (1992) Den påbegynte virkelighet. Studier i samtidskultur. Oslo: Universitetsforlaget.

Garnes, S. E. (1995) Ernst Blochs "Det ennå-ikke varendes Ontologi", og dets Genealogi. Oslo: Filosofisk institutt. Hovedoppgave. 


\section{TIL MINDE OM BYEN}

\section{Den refleksive udstillingstypologi i Memento Metropolis - en udstilling om længslen efter det $\mathrm{Ny}$}

\section{Line Hjorth}

Som princip er det museumsgenstande forundt at have en meget lang levetid. Det gelder hvad enten de eksisterer som eksponerede, skattede objekter i museets offentligt tilgangelige udstillingsrum eller om de lever en mere tilbagetrukket tilvarelse på hylderne i magasinet. I kraft af deres ofte hoje alder formair de at fortelle om andre tider og livsmåder og gøre sammenhange anskuelige, som ellers ville vare skjulte for et nutidigt blik. Anderledes forholder det sig med de udstillinger, som på en gang udgør rammerne for museumsgenstandene og gestaltes af disse. Udstillinger eksisterer over kortere eller langere tidsperioder, andres måske i form eller viger helt til fordel for andre udstillinger, tilrettelagt efter andre videnskabelige eller nyere estetiske principper. De lader sig dokumentere og arkivere som billede, tekst eller model og transformeres på denne måde over $i$ andre medier, men som fysisk sanselig konstruktion og som et medium med saregne karakteristika, gär de tabt. Set ud fra et museologisk astetisk synspunkt er der imidlertid gode grunde til at prove at forstå udstillingerne som en slags 'objekter', der i lighed med andre museumsgenstande, kan trakkes ud af udstillingshistoriens magasin med det mål for øje at frembringe ny erkendelse om museets idé og vasen.

Gennem de sidste 10-15 år er flere udstillinger begyndt at reflektere over disse forhold, og der er efterhånden dannet et empirisk grundlag for at definere, hvad man kan kalde en "refleksiv udstillingstypologi". I 1993 viste Nationalmuseet i København Museum Europa, en udstilling om det europæiske muse- umsvæsen gennem 600 år. Museumstemaet blev indgående belyst ved hjælp af mere end 1300 genstande lånt fra kunstmuseer, $\mathrm{Na}$ tionalmuseets egne samlinger og fra andre kulturhistoriske, medicinhistoriske, etnografiske og zoologiske museer. Desuden indgik en række samtidskunstneres værker, der reflek- 
136 terede over museets væsen. I dette museum i museet og i en form, der ligestillede kunstnerisk tolkning med tingenes egne fortællinger, skildrede udstillingens kuratorer Annesofie Becker og Willie Flindt, hvordan hver tidsepoke har set på verden og videnskaben med forskellige øjne, og at de stadigt skiftende blik, som har formet tidens museer, også afspejler, hvordan vi har indrettet verden ${ }^{1}$.

Museum Europa eksemplificerede "den refleksive typologi" i sin idealform. Betegnelsen har jeg fundet dækkende for en tendens, der i sin form reflekterer over udstillingens egne kommunikative og æstetiske potentialer og peger på museets idé, oprindelse og historie som et autonomt felt $\mathrm{i}$ den moderne kultur. Refleksive udstillinger iscenesætter museets eget arkiv af måder at ordne og præsentere ting på. De er markant bevidste om mediets egenart og afviger fra idéen om at være anonymt, objektivt vedhæng til et forudgående stykke forskningsarbejde. Derimod er de æstetisk funderet formidling, som bringer udstillingsmediet på linie med film, fotografi, teater og litteratur. I stil med disse medier benytter de et varieret register af former, som også giver plads for, at udstillinger kan være polemiske, kritiske og gøre op med stereotype virkelighedsrepræsentationer.

Kriterierne for typologien er opstillet på baggrund af iagttagelser af udstillinger foretaget herhjemme og i udlandet i 1990'erne i forbindelse med udarbejdelse af min kandidatafhandling ved Moderne kultur og kulturformidling på Københavns Universitet. Endvidere gav en stilling som informations- og udstillingsmedarbejder ved Memento Metropolis - en udstilling om langslen efter det $N y$, et nært kendskab til de arbejdsprocesser og overvejelser, der lå forud for den færdige udstilling. Udstillingen blev skabt af Museum Eu- ropas kuratorer som del af Kulturby 96, og var et af det københavnske kulturbyårs flagskibe.

\section{I 'Elektrisk Station'}

I storbymiljøerne i sidste halvdel af 1800-tallet, frem imod år 1900, genereredes nye tankemåder og kunstneriske retninger, som skulle komme til at præge resten af århundredet helt op til vor tid. Storbyerne var centrer for kulturel og intellektuel udveksling, fortættede knudepunkter for tradition og fornyelse, ekstremernes mødested, som for eftertiden har knyttet storby og modernisme sammen i et uadskilleligt greb. Det var denne moderne storby, Memento Metropolis - en udstilling om langslen efter det $N y$ ville erindre. Ved hjælp af kulturhistoriske tableauer over storbylivet, patenterede videnskabelige opfindelser, gamle evighedsmaskiner og 21 samtidskunstneres værker, ville den genkalde erindringer om det urbane rum, der skabte forudsætningerne for den moderne tids forandringer i kunst, teknologi, videnskab og hverdagsliv. Byen var derfor ikke en hel, genkendelig eller faktisk geografisk by, men byen i fragment, spor og antydning.

Ifølge kuratorerne, der også var ophavsmænd til selve udstillingsidéen, ville Memento Metropolis fortælle om: "... to idéer, der har præget kunsten, filosofien og videnskaben i den samme periode, som værket var i drift, nemlig idéen om det Nye og idéen om Afslutningen. Udstillingen stiller det følgende spørgsmål: Hvordan husker vi livet i de store europæiske byer, som er rundet af det 19 . århundrede, her ved overgangen til det 21 . århundrede? Hvordan var det at leve i en tid, som på den ene side var lidenskabeligt besat af idéen om det $\mathrm{Ny}$, der skulle gøre verden 


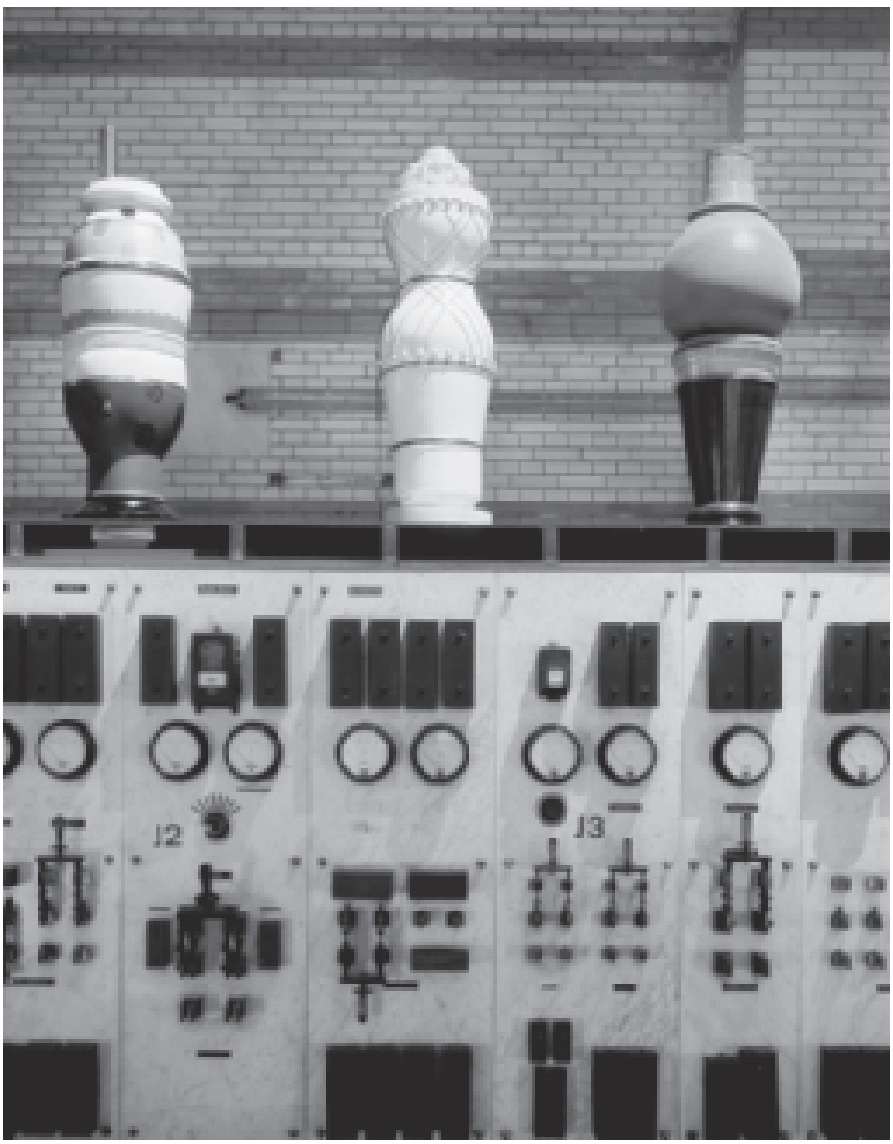

bedre og skønnere, og på den anden side var præget af en rodfæstet nihilisme blottet for fremskridtsforventning, men til gengæld opfyldt af undergangsvisioner?" (udstillingsprospekt, indledning).

I regi af Kulturby 96, blev Memento Metropolis vist i Turbinehallerne i det indre København. Fra 1892 sikrede elværket, der oprindeligt hed 'Elektrisk Station', den nye storby en central elforsyning. I hele sin gedigne og smukt udførte konstruktion udstrålede bygningen, at den havde rødder i en peri- ode, som troede på fremskridtet og havde en optimisme i fuldt behold. Bårer i jern, som stod tilbage fra dengang værket var i brug, mindede dog også publikum om, at udviklingen og fremskridtet havde en pris, og at de kræfter, der lå til grund for det ny, ikke altid lod sig kontrollere. Det nedlagte elværk, der i midten af 1990'erne fik navnet Turbinehallerne, dannede således en relevant ramme omkring en udstilling, der ville gestalte erindringen om det 20. århundredes storby og de både positive og negative værdier, der skab- 
138 te den. Med sine enorme sale og mindre rum forbundet af trapper, nicher og kældergange og med en tredive tons tung rullekran, som svævede højt oppe under loftet, samt ure, kontakter og elektriske kontrolpaneler, fremstod hele værket med en stærk historisk aura. På mange niveauer var mødet med bygningen $\mathrm{i}$ sig selv en storslået fortælling i sten, kakler og jern om den moderne tid, der længtes efter det ny og en stor udfordring for kuratorer, billedkunstnere og publikum. Forløbet blev hverken kronologisk eller historisk enstrenget, men kom snarere til at følge elværkets labyrintiske arkitektur, som bandt de mange kunstværker og tableauer sammen til et autonomt udstillingsværk.

I rammen af elværket forenedes kunstneriske udtryksformer med et kulturhistorisk funderet emne og med genstande af både historisk, kulturhistorisk og naturvidenskabelig karakter, som lagde forskellige vinkler på temaet. At gå igennem udstillingen var samtidigt en vandring gennem forskellige udstillingsmåder fra barok encyklopædisk ophobning til panorama, diorama, taksonomi og moderne galleriagtige ophængninger af kunstværker. I en markant kurateret og lysdesignet mise-en-scène fremstod billeder og genstande med stærk visuel effekt. Tingene blev fremhævet som usædvanlige, smukke, uhyggelige eller på anden vis iøjefaldende, og som et gennemgående træk måtte beskueren selv afsøge dem mening og sammenhæng.

\section{Memento Metropolis}

\section{- EN REFLEKSIV UDSTILLING}

Følgende belyses Memento Metropolis ud fra de kriterier, der tilsammen udgør den refleksive udstillingstypologi. Med accenten lagt på udstillingsformen bliver Memento Metropo- lis dermed selv gjort til genstand for erindring. Temaet om storbyen som dynamo for moderniteten og som vogter af civilisatoriske værdier træder i baggrunden, selv om de hver især var aspekter af den komplekse udstilling. ${ }^{2}$ "Form" skal i denne sammenhæng ikke opfattes som en tilfældig indpakning af udstillingens "indhold", men derimod som det særlige sprog, der åbnede for nye måder at anskue byen på. Selv om form og indhold betinger hinanden og ikke kan skilles, er en opdeling i talen om udstillingen nødvendig, og det er formålet at vise, hvordan Memento Metropolis formidlede idéen om den moderne storby. Udstillingen var en udstillingssproglig fornyer, der udfordrede museets traditionelle objektive formidlerrolle og vores forestilling om, hvad en udstilling kan eller bør kunne. I sin form pegede den fremad mod en tendens, der bliver stadigt mere synlig internationalt såvel som i nordisk museumssammenhæng. Da de mange værker og tableauer netop skulle ses som erindringer, udgjorde den et moderne memorieteater om storbyen som bevægelse, idé og tilstand og fremhævede museologisk refleksivt, hvad der fra de helt tidlige museer har været en af museets fundamentale idéer: at bringe i erindring, at minde om.

Den refleksive typologi er at se som et system af forskellige kriterier, der hver især kan varieres i et utal af former. Hvis variation er den ene elementære forudsætning for typologien, er den åbne position, som tingene indtager i udstillingen, en anden. Med et begreb fra museologen Krzysztof Pomian optræder disse som semioforer, ting, der forbinder adskilte sfærer, synligt og usynligt, nært og fjernt, konkret og imaginært. De er åbne tegn, der henviser til noget andet end sig selv og kalder på fortolkning. Når en ting mister sin nytteværdi og bliver til museumsgenstand, får den 


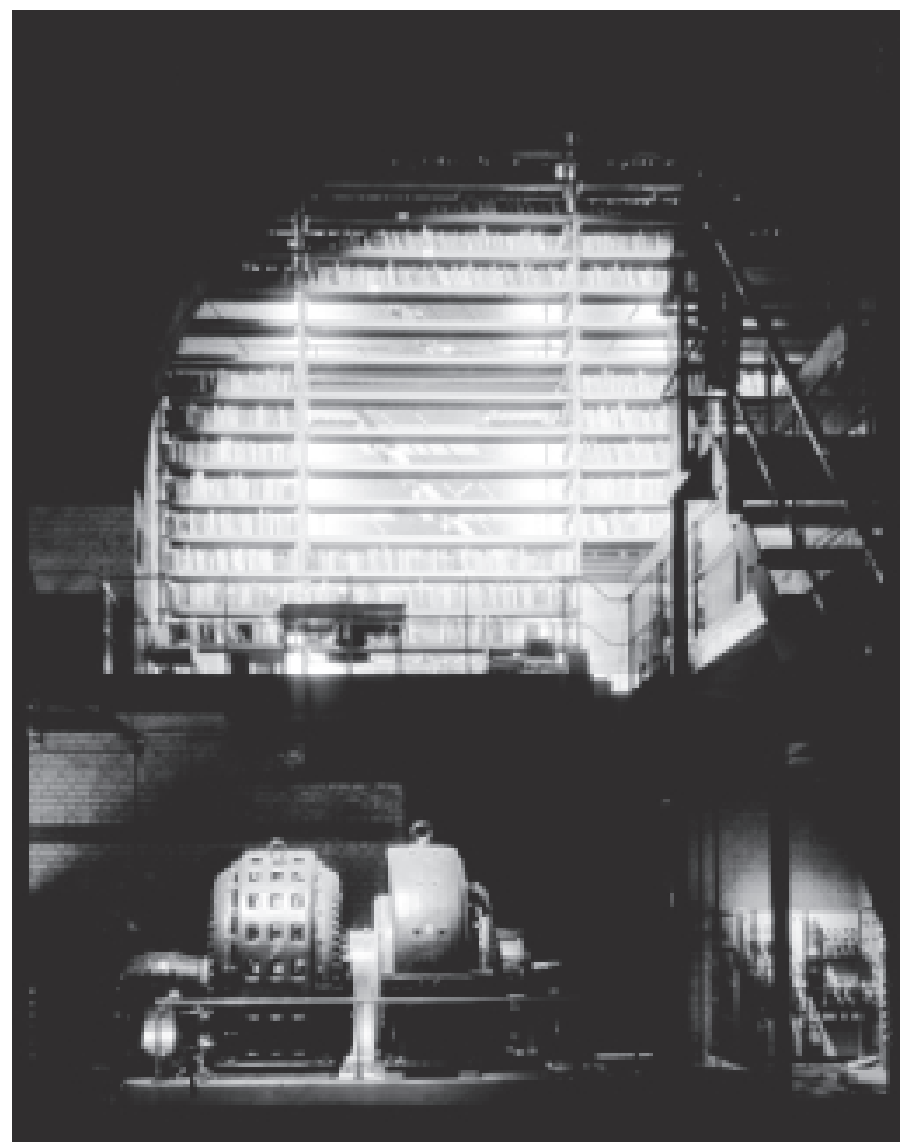

I et Antikvariatbibliotek kunne man bytte en medbragt bog til en af bibliotekets 50.000 boger. Bogbytningen foregik efter vagt og kondenserede udvekslingen, modet og vilkairligheden som grundlaggende urbane vardier og fungerede på denne måde som udstillingstematisk koncentrat. Bogsamlingen var udvalgt af antikvarboghandleren $i$ Politikens Antikvariat i Kobenhavn, der gennem sit valg kom til at stå som grundlagger af et bibliotek indeholdende de boger han mente burde inga $i$ metropolens 'verdensbibliotek'.

i kraft af sin evne til at kommunikere noget for nogen, en ny værdi. Frem for at ting fremstår belærende eller som entydigt bevismateriale, er det denne åbne tegnstatus, der karakteriserer den refleksive udstillings objekter. Som bindeled mellem beskueren og det imaginære fremstår de flertydige og lader sig altså ikke reducere til didaktisk, historisk bevismateriale. De enkelte kriteriers variationspotentiale og genstandens åbenhed grunder i en accept af tingens egetliv, og de udgør grundlæggende forudsætninger, som den re- fleksive udstilling gør til sin strategi. Men uanset hvor åben og anti-autoritativ en genre end forekommer at være, rummer den teoretiske typologisering altid en risiko for at forsimple. Risikoen må imidlertid betragtes som genreteoriens vilkår. Til gengæld kan kriterierne bruges som orienteringspunkter i et ujævnt terræn af udstillingsformer med de fem kriterier som analytiske redskaber til at pejle sig ind på typologien; de angiver gradforskelle og danner tilsammen en idealmodel af den refleksive typologi. 


\section{FEM KRITERIER FOR EN TYPOLOGI}

Første kriterium vedgår udstillingens estetik. Refleksive udstillinger iscenesætter ofte genstande og værker på en måde, som overrasker, forundrer eller på anden vis vækker til eftertanke eller beundring. Derved adskiller de sig fra repræsentative udstillinger, der stræber efter at fremstille det typiske. I overensstemmelse med et moderne kunstværks autonomi, dets væren i sig selv, frem for dets henvisende, implicerende karakter, er værkbegrebet i refleksiv sammenhæng kendetegnet ved en autonomi, der adskiller det fra hævdvundne ordenssystemer, f.eks. kronologi og historie, taksonomi eller evolutionært hierarki. Den overraskende form lægger op til, at man som museumsgxst selv skaber forbindelser mellem de udstillede genstande ved hjælp af en associativ tankegang, der i senrenæssancens wunderkamre var en almindelig accepteret metode til at erkende samlingens idé. At så meget er op til beskueren gør, at refleksive udstillinger ofte beskyldes for at være elitære. Spørgsmålet er dog, om ikke det modsiges af udstillingens åbenhed og eksponering af genstande, fordi disse også kan ses uden tanke på bagvedliggende udstillingsprincipper. Formen er ofte skabt i en mise-en-scène, et udtryk fra filmterminologien, der inkluderer sider af mediet, som overlapper med teatret: lysdekoration, kostumer og figurernes fremtræden, samt den enkelte kameraindstillings dekorationer, skuespil, billedkomposition etc., der udgør billedudtrykkets helhed. Også refleksive udstillinger er sat i scene, ofte ved hjælp af lys- og lyddesign og med en nøje sans for den samlede visuelle effekt.

I filmisk mise-en-scène kræves instruktørens overblik og kontrol over alle aspekter inden for billedets ramme. På grund af sine flek- sible grundelementer lægger den refleksive udstilling ligeledes op til et markant, styrende greb, som gerne foretages af en kurator, hvis personlige stil og præferencer bliver gennemtrængende for hele udstillingens fremtræden. Kuratorbegrebet henviser i sin etymologiske betydning til forvalterrollen (lat. cura, omsorg, omhu), en opgave, der traditionelt set var museumsinspektørens. I en museologisk refleksiv kontekst indebærer kuratorbegrebet derimod en subjektivt iscenesættende funktion, der kan sammenlignes med forfatterens. Typologiens andet kriterium er således, at kuratoren optreder som auteur. ${ }^{3}$

Tredje kriterium er museologisk refleksion, som henviser til, at udstillingerne på en citerende måde låner fra museumshistoriens reservoir af udstillingsmåder. Det inkluderer for det første det moderne offentlige museums mange iscenesættende former, fra en tidlig konservatorkunst og zoologiske habitatdioramaer til frilandsmuseer, øko-museologi og etnografiske opstillinger af fremmede kulturer $i$ en naturalistisk setting eller pædagogiske "moser", som de er kendt fra det danske Nationalmuseums populære Brede-udstillinger. ${ }^{4}$ Senrenæssancens wunderkamre, studioloer og raritetskabinetter giver i kraft af deres forkærlighed for det kuriøse eller gådefulde tillige næring til typologiens museologiske appropriationer, der iscenesættes som udstillingsobjekter i sig selv.

Fjerde kriterium, det dioramiske perspektiv, beskriver udstillingens kontekstuelt orienterede form. Begrebet refererer til, at ting iscenesættes i en naturalistisk opstilling, som også kendes fra det zoologiske diorama, hvor udstoppede dyr vises i et naturligt habitat. Den kontekstuelle form er en videnskabelig tilgang, men adskiller sig eksempelvis fra taksonomien ved at indfange forskellige aspekter 
af en kompleks situation. Den svenske kulturgeograf Torsten Hägerstrand beskriver det dioramiske perspektiv som et, der "viser hen imod kæder af overlappende eller beslægtede områder, hvor fænomener af forskellig art eksisterer samtidigt". Det zoologiske diorama, som blev introduceret af den svenske jæger, konservator og forfatter Gustav Kolthoff i slutningen af 1800-tallet, bestod tilsvarende af dyr, planter og insekter, som lever inden for samme område. Kolthoffs idé reflekteres således i Hägerstrands tværvidenskabelige tankemåde, der også anvendes på forhold uden for museet. ${ }^{5}$ Styrken er, at alt som findes inden for et afgrænset udsnit af verden, opfattes som noget, der har en rolle at spille, og at det finkornede dioramiske blik fokuserer på mødesteder, processer og helheder frem for systemer af f.eks. adskilte regioner eller sammenhobede, taksonomiske størrelser.

Refleksive udstillinger appellerer gerne til flere sanser samtidigt, men da blikket styrer oplevelsen, tager det femte kriterium, optisk pluralisme, navn herefter. Pluralismen vedgår både brugen af forskellige medieformer, tableau, film, dias, musik, lys osv. og refererer samtidigt til, at temaet indkredses ved hjælp af forskellige disciplinære tilgange, kunst, kulturhistorie og naturvidenskab. For hver af disse tilgange kan benyttes flere medier, fotografi, tableau, computerteknologi, musik etc., der igen lader sig beskrive ud fra forskellige genrer. Sammenstillingen af tider, medier, kunstneriske udtryk og genrer skaber frem for enkle definitive udsagn, serier af oplysninger og et sæt af optikker, hvorigennem et tema lader sig betragte.

\section{Mosaik AF TING OG BILLEDER}

Litteraturforskeren Malcolm Bradbury har med tanke på byen i megen moderne litteratur fremhrvet (1976), at the city has not remained one thing; and the forms have not either. I lighed med de moderne forfattere, der i deres værker opløser byen som fysisk størrelse og transformerer den til nye mønstre via det enkelte menneskes sanser og erindring, kan Memento Metropolis anskues som en udstilling, der sprænger idéen om storbyen som et fysisk, håndgribeligt fænomen. Det sker i kraft af udstillingens form, som udfordrer den norm, at kulturhistoriske museumsudstillinger skal være overskuelig, pædagogisk formidling videregivet i et objektivt, entydigt formsprog. Med en heterogen struktur blev byen således metafor og form mere end afgrænset tid og faktisk geografisk sted, som også byen i megen moderne litteratur nærmest er blevet analog med form.

Ingen vejviser førte publikum gennem elværket, hvor også ting og billeder overvejende talte deres eget sprog, og den åbne, labyrintiske struktur, der overlod meget til beskueren, giver anledning til at se Memento Metropolis som en inspiration fra senrenæssancens eller barokkens wunderkamre. Disse var ofte iscenesat som et symbolsk mikrokosmos, der afspejlede et makrokosmos opbygget efter planetguderne og de fire elementer. I en noget løsere version refererede udstillingens mikrokosmos af ting og billeder til storbyens overordnede makrounivers. De gamle kunstkamre bestod især af unikke, kuriøse genstande, der krævede, at beskueren associerede relationer frem mellem tingene, og ofte var det kun samlingens ejer, som kendte til genstandenes indre forbindelser og idé. Samlingerne var "tings-mosaikker", som kunstkammerforvalteren eller naturforskeren havde sammenstillet, og mønstrene af ting var skabt med den hensigt at bringe ny erkendelse om 
142 virkeligheden til verden. På denne måde afspejlede samlingen den fortolkningsproces, der var en forudsætning for at opnå en større forståelse af verden.

De sparsomme udstillingstekster, den teatralske scenografi og lyssætningen, som fremhævede ting og arkitektur, gav Memento Metropolis et tilsvarende gådefuldt præg, som kaldte på beskuerens fortolkning. En farvestrålende balkon med plasticstole placeret nedenfor, et par barnesko med bykort i sålerne, store glaskasser med udtørrede måger opsat i kalligrafiske mønstre i en tom trappeopgang eller en hal med slidte møbler var en del af det kodede sprog. ${ }^{6}$ Den erkendelsesfunderede interesse, idéen om udstillingen som et mønster, der åbner til virkeligheden, samt et polyhistorisk blik, er på denne måde fælles for de tidlige museer og de nye refleksive udstillinger. Kunstværker og tableauer lod sig dog også blot betragte for deres egenartede skønhed, gru eller mærkværdighed, lige som man flere gange fik fornemmelsen af, at rummets grænser blev sprængt. F.eks. når et stort bibliotek rejste sig på et jernstillads under en loftshvælving, krukker med figur som gigantiske porcelænsfatninger dukkede frem på et panel med ure, håndtag og måleapparater eller når man i en halvmørk kældergang stødte på bybilleder fra Berlin i lysende transparens, opsat så de lignede butiksvinduer. ${ }^{7}$

\section{INSPIRATIONEN}

\section{FRA DEN TIDLIGE MASSEKULTUR}

Disse barokke præg i Memento Metropolis var et dominerende træk, men langt fra det eneste stilfragment, som prægede udstillingen. En anden museologisk grundform, det moderne panorama, som det blev kendt på offentlige pladser og markeder fra midten af 1800-tallet, prægede hele det første udstillingsrum, selve Turbinehallen. Panoramaerne er eksempler på noget af den tidligste moderne massekultur, tidens ultimative visuelle illusion skabt som en kombination af rum, lys, malerteknik og virkelighedstro sætstykker. De kostbare lærreder og scenografier var offentlige etablissementer for underholdning. De var store kulisseagtige billeder i et 360 graders vue, som f.eks. viste spektakulære udsigter over berømte byer eller gav publikum et på alle måder bjergtagende vue ud over smukke landskaber, dramatiske krigsscener eller viste andre aktuelle emner, gerne af nationalromantisk karakter. Samtidigt gav rundbillederne et bredt publikum indsigt i motiver og verdener, der før havde været utilgængelige, uden at de af den grund var ment som nøgtern folkeoplysning.

Turbinehallen udfoldede et helt panorama, der i et rundskuende vue blotlagde sin rustikke storladne arkitektur og en del af udstillingens urbane erindringsbilleder. Men modsat de gamle panoramaer, hvor man fra en midterplatform orienterede sig ved hjælp af synet, inviterede elværket den besøgende til aktivt at bevæge sig og indtage hallerne på egne præmisser. Og hvor man i 1800-talspanoramaerne benyttede kunstige sætstykker og modeller for at skabe den fuldendte illusion, var elværkets rum og industrielle levn autentiske: løftekran, generator, kontrolbord, måleinstrumenter og et stort håndtag, hvorfra man engang kunne tænde og slukke for byens lys.

Panoramaformen var også repræsenteret i en anden version. Indgangsbilledet var en 35 $\mathrm{m}^{2}$ stor kopi efter den franske maler Théodore Géricaults Medusas Flåde, udført af malerne Guillemet og Ronjat. Billedet forestiller ofrene på en nødstedt tømmerflåde og blev oprindeligt malet som en anklage mod den 


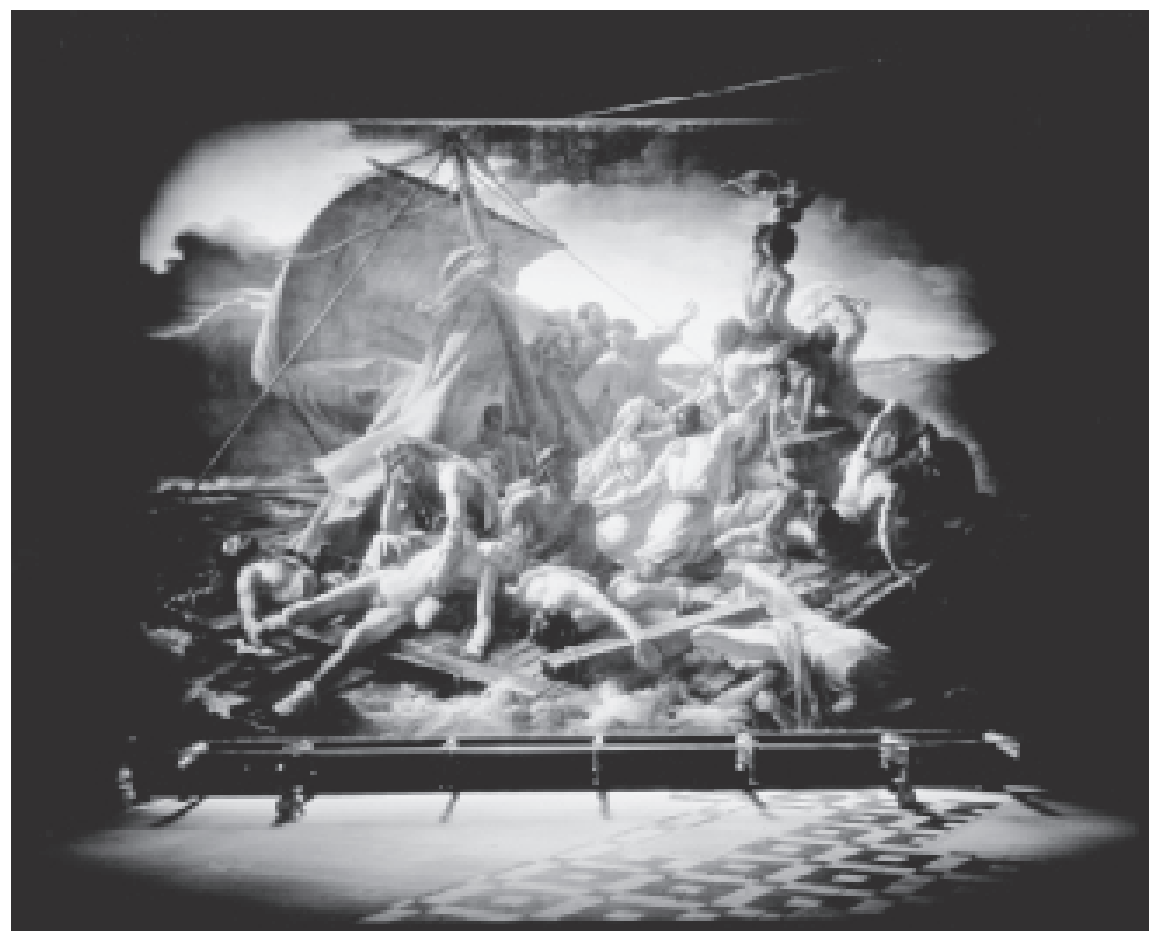

Jean-Baptiste-Antoine Guillemet og Etienne-Antoine Eugène Ronjats Le Radeau de la Méduse (1860), kopi efter Théodore Géricault (original 1819). Musée de Picardie, Amiens.

franske stat, da den i 1816 forbrød sig imod det ny demokratis løfte om lige ret for alle. En fransk fregat forliste på en rejse til koloniområder i Senegal, og de af lavest sociale rang blev sat over på en tømmerflåde, der i dagevis drev omkring på havet med død, sindssyge og kannibalisme til følge. Skibskatastrofen blev sin tids mediesensation, og Géricaults billede blev første gang udstillet $\mathrm{i}$ 1819 på salonen i Paris, hvor det vakte kritikernes foragt og publikums begejstring. Endvidere blev det vist frem i showkongen William Bullocks kombinerede udstillingslokaler, voksmuseum og moderne kuriositetskabinet i London fra juni til december 1820, hvor 40000 mennesker så det. ${ }^{8}$ Maleriet var ikke noget almindeligt rundt panorama, men Bullock udnyttede publikums panoramavante blik og lancerede det på samme storstilede måde som panoramamotiverne af kendte slag og landskaber.

Denne oplysning blev ikke givet i udstillingen, men anskuet i relation til den refleksive typologis brug af museologiske formfragmenter kunne billedet opfattes også som en kommentar til udstillingsmediets generelle underholdningsværdi og relation til gøglet. Det fremhævede den forbindelse og indbyr- 
144 des påvirkning, der har været mellem moderne massekulturelle fænomener, verdensudstillinger, panoramaer, varemagasiner, butikspassager, forlystelsesparker og museum fra midten af 1800-tallet; forbindelser, der også eksisterer i en nutidig museums- og massekultur. I kraft af sit motiv og den stærke naturtro portrættering af ofrene på tømmerflåden, farvet af kunstnerens egne personlige idéer og generøse malerstil, forstærkede Medusas Fläde det i forvejen imposante indtryk man fik afTurbinehallens enorme rumfang og særlige atmosfære. Det havde den meget praktiske effekt, at beskueren helt spontant slog øjnene op og måske beredte sig på en udstilling, der vitterligt krævede åbenhed fra først til sidst.

Forbindelsen mellem billedet og storbytemaet var imidlertid mindre indlysende. Selv hvis man oplevede Medusas Flåde som symbol eller varsel om den gru, der skulle komme til at præge det 20. århundrede (en pointe, der blev antydet i billedets genstandstekst), krævede det flere filosofiske og historiske mellemregninger at nå fra Géricaults politiske dokumentarisme til metropolen og længslen efter det Ny. Som en slags billedsprogligt udråbstegn henledte maleriet derfor især opmærksomheden på udstillingens form og karakter af uforudsigelighed. ${ }^{9}$

Elværkets labyrint og mange overraskelser, autentiske levn fra fortiden, kunst og tableauer, giver yderligere belæg for at betragte dele af Memento Metropolis i forhold til de tidlige massemedier og til gøglet. I de underjordiske gange, hvoraf nogle strakte sig helt ud under gaderne, stødte man f.eks. på en bestialsk lydmaskine, som gav elektroniske skrig fra sig, hvis man gik den for nær. "The Marshall Installation" var skabt af kunstnerne Morten Skriver og Christian Skeel i samarbejde med Danmarks Tekniske Universitet og bestod af lydforstærkere af mærket Marshall, som først fungerede i det øjeblik, beskueren trådte ind i rummet mellem disse. Det startede med en dyb knurrende lyd, der varslede et øredøvende skrig, hvis lyden nåede sit maksimale niveau. Værkets idé var inspireret af en indsigt fra moderne teoretisk fysik om, hvordan vi bevidst eller ubevidst påvirker et rum ved vor blotte tilstedeværelse. Skrigene, der gav genklang i de halvmørke gange, gav dog også fornemmelse af at være havnet $i$ et mystisk hus, understøttet af stærke lysglimt, som brød ud igennem mellemrum, nicher og sprækker. En serie omvisninger var i lighed med almindelige turistprægede byvandringer tilrettelagt ud fra forskellige temaer med inciterende titler som "Musikken støjen vanviddet - storbyen”, "Tegn på Liv - Tingenes Fortællinger", "Det chokerende nye - om det moderne i kunsten og på gaden” m.fl. Dette tivoliserende aspekt er imidlertid kun et af mange. Grundlæggende udstrålede Memento Metropolis en alvor og stramhed, udtrykt i værker eller tableauer eller i de tekster, der ledsagede disse.

\section{VERDENSUDSTILLINGEN \\ OG SAMLINGEN SOM INSPIRATION}

Som en sidste inspiration, der her skal nævnes i relation til Memento Metropolis' spil med et museologisk arkiv af udstillingsmåder, er verdensudstillingen. De store udstillinger var i sig selv scener for det nyeste ny inden for industri, handel, kunst, medier og teknologi, men var samtidigt steder, hvor nye udstillingsformer blev afprøvet og etableret. De var skabt ud fra en idé om at samle hele verden under et fælles tag og rummede enorme ophobninger af både smukke og praktisk tekniske ting og opfindelser, samt staffage og 
dekorationer, iscenesættelser af eksotiske brokker fra alverdens kulturer, historiske epoker og stilarter. Udstillingerne trak opmærksomhed til byen og promoverede den både som værtsby og verdensby. At Memento Metropolis var del af et europæisk kulturbyår, der gjorde kunst og kultur til redskab for et politisk projekt, gør det relevant også at se udstillingen $i$ lyset af verdensudstillingernes lignende overordnede politiske og økonomiske formål. Udstillingen i Turbinehallerne blev til uden for museernes institutionelle rammer, men var til gengæld underlagt et politisk megaprojekts formål, normer og organisation. ${ }^{10}$

Memento Metropolis genskabte ikke wunderkammeret, panoramaet og dioramaet i oprindelig form, men lod dem indgå som museologiske klangbunde. Udstillingen var heller ikke verdensudstilling i miniature, men nævnes i denne forbindelse, fordi de store udstillinger omkring år 1900 materialiserede en længsel efter det Ny. "Længslen efter det Ny", udstillingens undertitel, kan således forstås som en længsel efter en historisk tid, hvor kunst, videnskab og samfundsliv ændrede sig på mange niveauer. Endvidere manifesterede længslen sig i udstillingen som en refleksion over modernitetens fremaddrift. I Turbinehallerne kom det, der er nyt i vor tid, bl.a. til syne i udstillingsdelen 'Opfindelsernes Katedral'. Katedralen var tænkt som et tematisk kondensat af længslen efter det ny og var måske det udstillingsafsnit, der tydeligst inkarnerede undertitlen. Her undersøgtes idéen om det absolut ny i form af skelsættende teknisk-videnskabelige opfindelser (bl.a. en model af Ørstedsattelitten, energibesparende Grundfosspumper og komponenter af nanoteknologi) vist i kombination med gamle evighedsmaskiner og nye kunstværker. Det nye i Memento Metropolis var dog især af udstillingsmæssig art, udtrykt i variationer 145 over kriterierne for den refleksive typologi.

\section{DIORAMISK PERSPEKTIV}

Selv om udstillingen var fragmentarisk opbygget, tilstræbte den ikke desto mindre i et dioramisk perspektiv at indlemme mange synsvinkler på bytemaet. Den viste, hvordan vidt forskellige fænomener eksisterer og påvirker hinanden og afspejlede urbanitetens kompleksitet inden for et begrænset område. Dette dioramiske perspektiv, (jf. Torsten Hägerstrand, se side 141), kom f.eks. til syne som nedslag eller snit gennem byens mange lag af levet liv. Memento Metropolis' refleksive storbyportræt lagde flere steder vægt på de sider af bylivet, man ofte overser. F.eks. viste tableauet Samleren dele af et faktisk eksisterende museum, privatmanden Johannes Peter Kattrups "Museum for Fundne Ting". ${ }^{11} \mathrm{Mu}-$ seets samlinger består af tabte ting, som Kattrup har samlet op i byens gader og minutiøst systematiseret efter arkæologiske forskrifter, datomærkning, registrering og sortering efter linier, former, farver og bevægelser. I nærheden var filmværket 'Terrain Vague' projekteret op på en femten meter høj endevæg. ${ }^{12}$ Frem for Samlerens gadeniveau bestod værket, der kørte nonstop, af optagelser fra storbyens udkanter. I dette ubestemmelige terræn af motorvejsudfletninger, klondykeagtige havnekvarterer og udefinerbare områder præget af opbrud og forfald, vandrede et bymenneske i skikkelse af den danske digter Henrik Nordbrandt. Værket viste de sider frem af en by, som hverken er traditionelle by- eller landzoner, men øde pletter, der ikke er indtegnet på noget bykort. Andre steder blev byen meget klart gestaltet som et centrum, enten for nye idéer i videnskaben og kunsten som i Opfin- 
146 delsernes Katedral, andre steder som magtens, krigens og katastrofens rum, eller byen blev skildret som naturlig organisme eller sted for babylonsk virvar.

Det dioramiske perspektiv fandtes endvidere i en udgave, der lå nærmere det oprindelige dioramas form. Således varierede flere værker habitatdioramaets hybrid af realisme og fiktion, fratrukket det traditionelle dioramas naturalisme og staffage. De udforskede dioramaet som en museal grundform med genremæssige variationer fra moderne kunstværk, dokumentar og traditionelt interiør til kuriøst privatmuseum. Tre tableauer indrettet under elværkets gulv viste scener af bylivets bevægelser og strømme. Bynomadens bolig var en minimalistisk indrettet lejlighed, som i størrelsesforholdet 1:1 var flyttet ind fra Nørrebro i København og genopbygget i Turbinehallen af museumskonservatorer. I 10 år dannede lejligheden base for en virkelig bynomade. Boligen stod i udstillingen som et spor af det liv, der leves i det offentlige rum og minimerer privaten til transit for tøjskifte, søvn og notatskrivning. Tableauet lånte træk fra Artur Hazelius' "stuga"/interiør-princip, og på grund af sin intime sfære fremkaldte det, ligesom oplevelsen af de gamle tableauer, en fornemmelse af at være trådt lidt for nær ukendte privatpersoners liv. Endvidere repræsenterede blotlæggelsen af lejligheden under elværkets gulv en museologisk metode i form af et stykke arkæologisk udgravningsarbejde i storbyens undergrund.

\section{Kunsten OG KROPPEN ISCEnESAT}

Auteur-kuraterede udstillinger beskyldes ofte for at påtvinge kunsten bestemte betydninger eller for at sætte for snævre tematiske rammer, som ændrer eller fastlåser kunstens åben- hed. Undertemaet "længslen efter det Ny" er imidlertid så bredt, at den meste moderne kunst ville finde plads under den hat. Titlen Memento Metropolis, et mix af latin og græsk, som betyder noget nær "husk/i erindring om storbyen", giver ligeledes plads for en i teorien uendelig repræsentation af erindringens associative, imaginære art. Værkerne var valgt af kuratorerne med den subjektivitet, der heller ikke er den gængse censurerede kunstudstilling fremmed, og som også sætter præg på kunstmuseers samlinger. Videoptagelser fra mavesækken, hår vundet omkring en syrulle eller en fitnessmaskine ledte måske ikke, som flere andre værker, umiddelbart tanken på by. ${ }^{13}$ Som objekter, alle bundet til menneskekroppen, der i almindelig forstand stort set ellers var fraværende i udstillingen, mindede de imidlertid om, hvordan kroppen i byen hele tiden sættes i situationer, der er unikke for netop dette rum: tætheden med andre kroppe, bevægelsen, tempoet, iscenesættelsen, beskuelsen fra og af andre kroppe etc.

Ifølge udstillingsprospektet ville man "holde blikket rettet imod de elementer, der ikke regnes for at have nogen historie - følelserne, samvittigheden, drifterne”. Men også mod kroppen som rum for en længsel, blev knyttet til storbyen og det moderne. Lå den pointe ikke lige for, så var oplevelsen af fysisk at bevæge sig gennem bygningen en kontinuerlig konfrontation med indretninger, der hele tiden kaldte kroppen frem ved at udelade den: En kunstner, der havde forladt sit atelier et sted i Sarajevo, bynomaden, der havde forladt sin bolig, samt et gigantisk kunstværk af den nu afdøde tyske kunstner Martin Kippenberger. Værket, The Happy End of Franz Kafkas 'America' (1994), var opstillet i den tidligere omformerhal og var Kippenbergers visuelle afslutning på Franz Kafkas ufuldendte 


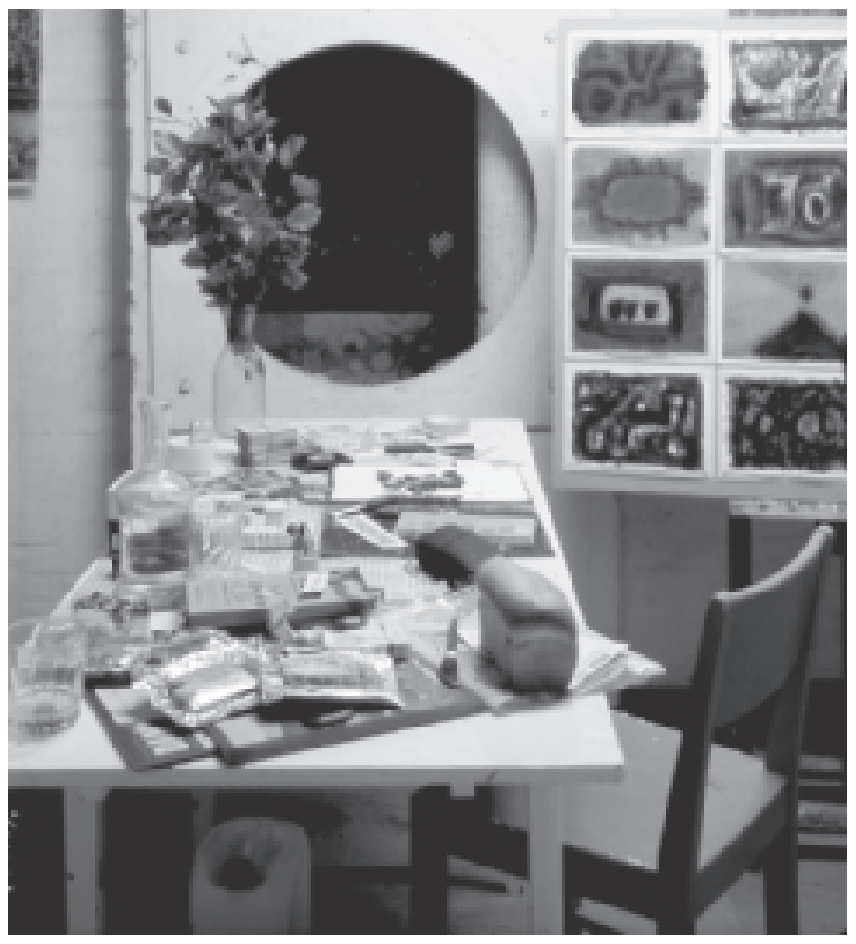

Edin Numankadics War Trails (1996), bygget op ved hjalp af elementer fra et krigsharget Sarajevo.

roman 'Amerika'. Det bizarre møbelcirkus bestod af borde og stole i enhver tænkelig afskygning. Værket var skabt som en ironi over jobsamtalesituationen som kampplads og over et samfund, hvor alle områder er gennemsyret af konkurrence, undertrykkelse og reklamestrategi. I dette samfund er den højeste værdi personlig succes, betinget af den enkeltes evne til at 'spille en rolle', opnå noget og få det anerkendt af en autoritet - at have et arbejde. Værket kunne ses fra den balkon, som løb hele vejen rundt og højt oppe i omformerhallen. Således var der rig mulighed for undervejs på rundturen enten at tænke sin egen krop ned i de mærkelige møbler eller forestille sig, hvem der mon kunne tænkes at tage plads i stolene, som hver især selv synes at personificere forskellige mennesketyper og -kroppe.

Endeligt var der konfrontationen med egen krop, når man vandrede gennem elværket. Det skabte fornemmelsen af, at udstillingsgæstens rolle på flere måder ligner byboens: Blikkets møde med arkitektur, ting og billeder og med andre udstillingsgæsters, følelsen af at se og selv blive beskuet.

I tråd med retninger inden for installationskunsten arbejdede mange af kunstnerne i Turbinehallerne med rumlige, sceniske opstillinger og med forholdet mellem udstillingsrummet og virkeligheden uden for udstillingen. To tableauer om Sarajevo skærpede dioramaformen som dokumentaristisk repræsentation af virkeligheden. Den bosniske billedkunstner Edin Numancadìc gav i værket War Trails en per- 
148 sonlig fortolkning af Sarajevos belejring fra 1992-1996. I et lille rum under elværket havde han genopbygget sit sønderskudte atelier med rester fra den ødelagte by: en tom FNnødhjælpspakke, patronhylstre, et brød og en pakke cigaretter, farver, pensler og billeder og på væggene citater af den tyske filosof Walther Benjamin og den østrigske forfatter Robert Musil. I War Trails blev dioramaet dokumentarisk og tragisk aktuelt, men værket var også et mere generelt udsagn om eksistens under krigen og om eksistensens skrøbelighed og vilkårlighed i det hele taget. Et andet sted var et tidligere vagtmesterkontor omdannet til en slags mindestue med familiefotos og brochurer fra den tidligere olympiadeby, alt kontrasteret af et farverigt bykort over de serbiske troppers stillinger og en "overlevelsesguide" for turister under belejringen. Som i et kinesisk æskesystem, et museum i udstillingen, kunne man gå ind i dette minderum, hvor en båndet stemme læste op fra gamle guidebøger og skønlitterære værker fra Bosnien. På denne måde gled dioramaformen fra at være distanceret iagttagelse til at være en omsluttende fremstilling, som inddrog alle sanser.

Flere kunstnere arbejdede målrettet med rummet og gav således ekko af realitetsbevidste kunstretninger fra 1960'erne, Pop Art, Environmental Art, Happenings, Minimal Art, Land Art og Neo-Dada, der ville ophæve grænsen mellem kunst og liv og udvide kunstbegrebet til at omfatte hele vor dagligdag. Rest-æstetikken dirigerede blikket hen på trivielle, betydningsløse ting og steder og frisatte øjets slavebundethed fra det, der sædvanligvis regnes for vigtigt og værdifuldt. Tingene lod sig imidlertid ikke reducere til skrabet realisme. For iscenesættes det hverdagsagtige, ophøjes også dette til noget unikt. Kunsten lader sig næppe gradbøje, men ved at ophøje skrot og undselige materialer fremstod værkerne i Turbinehallerne med en klar kunstnerisk aura.

Kunsten om forfaldet, det perifere eller på anden måde flossede byliv må ses som 'svar' på den katastrofiske vision, som var en af udstillingsprospektets grundtanker: "...hvis forskellen imellem by og land ophæves, når den ene storby kolliderer med den næste og kun efterlader vage og udefinerede grænseområder imellem sig, så er storbyen ganske enkelt ophørt med at eksistere. Uanset alle apokalyptiske tankefigurer. Sker det, så er den urbane civilisation også ophørt med at eksistere. Så har den ingen steder hjemme, bortset fra i erindringen" (prospekt, s. 3, indledning). Uanset, om man tilslutter sig tankegangen eller ej, forklarer det, hvorfor udstillingen var udformet som et memento. Fordi man fremstillede vor tids byer som truede størrelser, under opløsning (af pludselige katastrofer eller af egen ekspansion), fik erindringen karakter af beskyttelse, ligesom man udtrykte en længsel efter en tid, der ville det ny. Til gengæld blev prospektets katastrofiske vision modsagt af kunstværker og tableauer, fordi de gav et langt mere differentieret blik på byens muligheder også i fremtiden. Memento Metropolis rummede med sin optiske pluralisme og associative spor mange blik på, hvad en by er. Ikke mindst i kraft af et fornyende udstillingssprog og med de mange nye kunstværker skabt specifikt til udstillingen og elværket, tilbageviste Memento Metropolis, at byen har udspillet sin rolle som det sted, hvor nye tanker, idéer, og kunstværker bliver til.

\section{LÆNGSEL EFTER MUSEET}

Der kan være flere grunde til, at refleksive udstillinger insisterer på at være æstetiske, kom- 
munikative størrelser i sig selv, og at de trækker på museums- og udstillingshistoriske kategorier og former. Betragtet inden for museets egne cirkler er de udstillingssprogets avantgardister, der udfordrer museets traditionelle objektive formidlerrolle. Den refleksive typologi er i den henseende en slags opponent til traditionen og en museologisk sprogfornyer.

At museet medtænker sig selv som idé (eller at udstillinger uden for museumsinstitutionens rammer gør det) og eksponerer sit eget reservoir af former må ses i forhold til den udvikling, museumsudstillingen har undergået fra at være permanent samling til også at være skiftende særudstilling og led i museets markedsføringsstrategi. Det har medført, at udstillinger kan ses som medier på linie med film, fotografi og TV. Sat fri af rollen som kronologisk, "sandfærdig" historiefortæller har de fået flere registre at spille på, men er også blevet del af en fortløbende proces, hvor de hele tiden må generere nye opsigtsvækkende udtryk. Iscenesættelsen af ting og billeder og udstillingsrummets inddragelse som fortællende medspiller, involverer beskueren på en ny aktiv måde, frem for at lade ham være kontemplativ modtager. Det paradoksale ved ligestillingen af udstillingsmediet med andre medier er, at det tilsyneladende har fremkaldt et behov og en insisteren på museets egen historie og fysiske egenart. Den viser sig som en længsel efter museets "væsen”. I de refleksive udstillinger er der således en tendens til at understrege museets eller samlingens oprindelige art som tingenes sted, som sted for erkendelse gennem udstillingsmediets sanselige, tredimensionale karakter. Mediet gav og giver mulighed for at fremvise ting $i$ et flersidigt perspektiv, der ikke i et definitivt jerngreb fastlægger en betydning, men lader beskueren selv tolke, associere og undersøge.
Memento Metropolis i Turbinehallerne må i 149 sin sammensatte form og med sit refleksive, flerperspektiviske blik ses som et meget markant udtryk for denne bevægelse: At udstillingen som æstetisk bevidst og fleksibelt medium samtidigt vender tilbage til grundlæggende værdier ved museet og det at udstille.

Til gengæld sker fornyelsen desværre ofte på bekostning af fyldigere oplysninger om ting og værker, hvilket i flere tilfælde viser sig at være refleksive udstillingers svage punkt. Man kunne spørge, om noget ville gå tabt eller være ændret, hvis man i tilknytning til Memento Metropolis havde præsenteret tekster, som belyste de mange emner, den kastede frem i lyset, storbyen i kunst og forskning, fremskridtstro og nihilisme, modernitet, civilisation etc. Ikke nødvendigvis i tilknytning til hvert enkelt værk eller tableau, som i hele deres fremtræden opfordrede til en visuel koncentration, og ikke for at være 'brugervenlig' i den betydning af ordet, som indebærer reducering af oplysninger, men for at lægge det materiale frem, som dannede grundlag for eller relaterede sig til udstillingen. At lægge tekstmateriale frem er også at erkende, at ting og billeder taler et særligt sprog, og at dette sprog, grundet sin egenart, har grænser. Havde man været mere generøs med at formidle tekster, som relaterede sig til udstillingstemaet, ville man havde tilføjet den endnu en vinkel ved hjælp af det særlige materiale, som er det skrevne sprog.

\section{SUMMARY}

In memory of the city. The reflective type of exhibition exemplified in Memento Metropolis an exhibition about the longing for the New.

During the last 10-15 years an increasing number of exhibitions have engendered an empirical grounding 
150 for what can be characterized as a "reflexive exhibition type". This typology denotes a tendency for exhibitions to reflect the communicative and aesthetic potentials of the exhibition medium and point to the idea, genesis and history of the museum as an independent field of modern culture. In a clearly indicated mise-en-scène style, often mixing the areas of art, cultural history and science, reflexive exhibitions tend to stage a museological archive of principles and ways of systematizing and presenting objects. They are clearly aware of the peculiarity of the exhibition medium and diverge from the idea of the medium as an anonymous, objective appendage to a preceding research process. Instead, they are aesthetically based pieces of communication that render the exhibition medium comparable to that of movies, photography, theatre and literature. Like these media they use a varied register of forms and allowing the creation of critical or polemic exhibitions or exhibitions which oppose stereotypical representations of reality.

The article "In memory of the city" states five given criteria for the typology and demonstrates them with the example of Memento Metropolis - an exhibition about the longing for the New. On the basis of observations made throughout the 1990s both in Scandinavia and abroad the author describes five criteria: miseen-scène, the curator acting as auteur, museological reflection, dioramical perspective and optical pluralism.

Memento Metropolis was shown in 1996 as one of the events staged to mark Copenhagen being appointed European Cultural Capital. Set up in what is today known as "Turbinehallerne", a former power plant dating from 1892 situated in the very heart of the city, the building exactly expressed the theme of the exhibition and created a relevant historical architectural frame for it. Juxtaposing artworks, panoramas and tableaux of modern city life, the representation of the urban memories was meant to shed light on a way of thinking that has marked the world until today: The "Longing for the New" propelled science, art and philosophy into a steady flow of new experiments. Memento Metropo- lis offered its viewer many ways into its complex theme. Things spoke very much for themselves through materials, expression and special positioning in cellars, halls and on the tiled balconies. Crooked birds' skeletons forming scriptlike patterns, one million years stored in ten black portfolios, a modern version of the classical library where books could be exchanged according to weight, a gigantic copy of the French painter Théodore Géricault's "Le Radeau de la Meduse" (original 1818/19) could all be seen in the exhibition.

Following the criterion of museological reflection the article traces the many different inspirations and aesthetic fragments which appear in the halls and cellars of the power plant; baroque "wunderkammer", early visual mass culture (panorama, diorama, delusion, buffoonery), and the complex of the Great Exhibitions. More than explaining the content of the twenty or so new artworks and historically inspired tableaux in relation to the theme of the metropolis and the longing for the new, the aim of the text is to show how "form" is not a fortuitous wrapping of "content" but the specific language which opens up new ways of looking at the idea of the modern city. Memento Metropolis renewed the language of exhibitions and challenged the traditional objective status of the museum and our ideas about the limits of the medium. The artworks and tableaux were intended to be regarded as memories and transformed the building into a modern "memory theatre" dealing with the life, movements and idea of the city. In this way the exhibition emphasized, in a museological reflexive style, what has been a fundamental part of the museum from its very beginning: to incorporate into our memory, to remember for us.

\section{Noter}

1. Museum Europa blev vist på Nationalmuseet i 1993 og i 1994 i Kunst- und Austellungshalle der Bundesrepublik i Bonn. Memento Metropolis - en udstilling om længslen efter det $\mathrm{Ny}$ blev vist i Turbinehallerne i København i 1996, året 
efter i Antwerpen og i 1998 i Stockholm. Som bekræftelse på, at den refleksive typologi fortsat er aktuel, kan det nævnes, at der i dette efterår atter realiseres refleksive udstillingsprojekter i regi af den dansk-svenske fond Kulturbro. Foruden en stor nordisk/baltisk manifestation på Nationalmuseet kurateret af den tyske kurator Marie Louise von Plessen, vender den amerikanske multikunstner Robert Wilson tilbage til Øresundsregionen med et projekt, som kobler kunst og markedsføring. Robert Wilson skabte vinteren 2000 udstillingen Anna didn't come home that night, som var en totaliscenesættelse af det danske Kunstindustrimuseums samlinger. Filmmanden Peter Greenaways Flying over Water i Malmö Konsthall, 2000, demonstrerede den refleksive typologi i en markant cinematisk form, og Lunds Konsthal viser i efteråret Kulturbroudstillingen Liv og Död om de gamle universitetmuseers samlinger, og reflekterer således i hele sit oplæg over museets idé.

2. Med 11. september som seneste eksempel på, hvordan metropolen gøres til angrebspunkt, er begge aspekter fortsat uhyggeligt relevante. Katastrofen har i sig selv affødt en række nye museums- og erindringsprojekter. Om dette se Barbara Kirshenblatt-Gimblett i Samtid\&Museer, nr. 3-4, nov. 2001, årg. 25.

3. Filminstruktøren og iscenesætteren Peter Greenaway benytter begrebet $i$ en beskrivelse af sin egen tilgang til film- og udstillingsproduktion: "...You can - without fear of argument - use the word to describe the maker of a novel. I have a set of characteristics that, welded together, I suppose, can be recognized as a specific personal style - though they are not manipulated to be stylish...", s. 13 in Pascoe.

4. Begrebet "mose" stammer fra Brede-udstillingen "Den hellige mose", 1968, hvor et tableau viste en højmose med ofre og mosefund. Begrebet er senere blevet fast museumsjargon som udtryk for det naturalistiske, åbne tableau.

5. Torsten Hägerstrand (1983) har bl.a. anvendt metoden på regional planlægning, studier om sundhedsudvikling, ældre borgere, kommunikationsteknologi, forholdet mellem teknologi og landskabsevolution og undersøgt, hvordan komplekse sociale, teknologiske og geografiske sammenhænge spiller ind på hinanden.

6. Det var værkerne "As Long as You Are Here" (1996) af Mikael Thejll, "Landscape" (1996) af Kathy Prendergast, samt John Olsen og Lars Abrahamsens "Forgængelighedens kalligrafi I og II", 1996.

7. Biblioteket var tableauet "Antikvariatbiblioteket", hvor man ved en bibliotekars hjælp kunne bytte en medbragt bog til en af bibliotekets 50.000 bøger og derved sætte nye spor i samlingen. Bogbytningen foregik efter vægt og kondenserede på denne måde et vores mulighed at påvirke byrummet ved aktivt at færdes og agere i dette. Biblioteket opsummerede udvekslingen, mødet og vilkårligheden som grundlæggende urbane værdier og fungerede i lighed med andre tableauformer som udstillingstematisk koncentrat. Endvidere var biblioteket en parafrase over museet som sted for ophobning af viden og erindring og måske et hint om at betragte hele udstillingskonceptet som et tilsvarende arbitrært arkiv over den moderne storbys uforudsigelighed. Der er desuden tale om billedkunstneren Torben Ebbesens "Beholder I-V" (1991-96), samt den tyske kunstner Sabine Hornigs "Twins" (1996).

8. Oettermann, 1980.

9. Endeligt udgjorde kopien af Medusas Fläde i sig selv et 'fund', hvilket føjer en yderligere refleksiv pointe til Memento Metropolis såvel som til billedets mange lag af fortællinger. I samarbejde med museumsinspektør Thorkild Kjærgaard lykkedes det udstillingskuratorerne Becker og Flindt at finde frem til denne tidlige kopi fra 1859/60 udført af de to malere Jean-Baptiste-Antoine 
152 Guillemet og Etienne Antoine Eugène Ronjat. I det franske provinsmuseum Musée de Picardie havde billedet ligget hengemt i ca. 60 år og blev først i 1996 vist frem for et publikum igen.

10. Professor Christian Wichmann Matthiessen har beskrevet kulturbyåret i København som redskab $\mathrm{i}$ en politisk proces: The 1996-event is seen as a support to restructure the economy of Copenhagen from a postindustrial service economy to an economy based on advanced services with creativity, communication, culture and knowledge of high international quality. The great effort that Cultural City '96 represents is part of the positioning among European metropoles (Mathiessen 1995:79 i Kindberg, Munkgård Pedersen og Poulsen). Som instrument til omstrukturering af byens $ø$ konomi og led i konkurrencen mellem europæiske storbyer udtaler overborgmester Jens Kramer Mikkelsen tilsvarende: Kulturbyen er en anledning for os alle til at tage os mere sammen. Vi skal bruge begivenheden til at give byen et loft, til at styrke selvrespekten og selvtilliden $i$ København, og det er vigtigt at sla fast, at Kulturby 96 ikke er noget mål i sig selv. Kulturby 96 er kun startskuddet.... Kulturby 96 er nødvendig for Københavns genrejsning. Det er en af de hjørnestene, der skal bidrage til, at dynamikken for alvor vender tilbage. Andre vigtige hjørnestene er den faste forbindelse over Øresund, Ørestaden og store investeringer i byggeri, f.eks. ved havnefronten. Berlingske Tidende jan. 1996.

11. Museet er beliggende i Helsingør, og kan besøges efter aftale.

12. Kunstværket var skabt af Dola Bonfils, Prami Larsen og Steen Møller Rasmussen.

13. Der er tale om værkerne Maveskulptur (1993) af den australske performancekunstner Stelarc, bl.a. kendt for sine 'kropsophængninger', hvor han nøgen lader sig ophænge i fiskekroge på kunstmuseer eller over åben gade; den irske kunstner Kathy Prendergasts The End and The Beginning, tre generationers menneskehår (1996), samt tableauet Kropsmaskine, en motionsmaskine, som tilgodeser hele kroppens muskulatur. Kropsmaskinen fortalte om kroppens forandrede funktion fra fysisk arbejdsredskab til objekt for kunstig træning, kontrol og beskuelse.

\section{LITERATURLISTE}

Becker, Annesofie og Flindt, Willie: Memento Metropolis-en udstilling om langslen efter det Ny, Prospekt, 1996

Bradbury, Malcolm og McFarlane, James: Modernism, Penguin Books, 1976

Hjorth, Line: Byen erindret - byen på ny, om Fritz Langs Metropolis og Memento Metropolis, to Kulturby 96-arrangementer i Turbinehallerne, KACTUS, Kunstakademiets Arkitektskole, Center for Tværfaglige Urbane Studier, 2001

Hjorth, Line: Den refleksive udstilling belyst ved en museologisk og udstillingshistorisk tilgang, Kandidatafhandling v. Moderne kultur og kulturformidling, Institut for litteraturvidenskab, Københavns Universitet, 1999

Hägerstrand, Torsten: "Presence and absence: A Look at Conceptual Choices and Bodily Necessities" in: Regional Studies, Vol. 18.5

Kindberg, Dorte L., Munkgård Pedersen, Kristine og Poulsen, Tine: Dublin 1991, Europaisk Kulturby, RUC, 1997-98

Oettermann, Stephan: Das Panorama. Die Geschichte eines Massemediums, Syndikat, Frankfurt 1997

Pascoe, David: Peter Greenaway, Museums and Moving Images, Reaktion Books, London 1994

Pomian, Krzysztof: Collectors and Curiosities: Paris and Venice 1500-1800, Polity Press, London 1990

Line Hjorth er ph.d. studerende,

Institut for Kunsthistorie, Aarhus Universitet.

e-mail: line.hjorth@jubiipost.dk 


\title{
REPRÆSENTATION ELLER BELÆRING?
}

\author{
Jørgen Hein
}

Enevaldens Danmark havde to store samlinger, Rosenborg og Kunstkammeret, der begge havde et betydeligt indhold af kunsthåndvark. Hvor gik skillelinjen? Hvad var deres opgaver?

Fyrstesamlinger blev en del af undersåtternes identitet og danner grundstammen $i$ mange museer, hvorfor deres indhold har stor museologisk interesse. En dominerende tendens $i$ den sidste generations forskning har varet studiet af renassancens kunstkamre, hvis grundidé var at lade udvalgte genstande afspejle menneskets viden og forestillinger om omverdenen. Dette nybrud, der forudsatte klassifikation af genstande og strukturering af viden, har delvist skygget for, at mange kunstkamre kun havde en kort levetid. Allerede 0.1600 blev de betydeligste forenet med eller måtte afgive de bedste af deres genstande til skatkammersamlinger, der stod direkte under fyrstens kontrol og havde reprasentation som det primare formål. Udtrykt starkt forenklet fik skatkammeret en renassance i barokken.

Denne udvikling fik også konsekvenser for Danmark, hvor samlingshistorie traditionelt er synonym med Frederik III's Kunstkammer, der blev grundlagt på Københavns Slot o. 1650. Enevælden havde imidlertid også et skatkammer, der blev indrettet på Rosenborg o. 1660 og hurtigt fik et betydeligt indhold af kunsthåndværk og paradevåben. Internationalt var de to samlinger således sildefødinge, hvorfor disse overlapninger kan undre. I det følgende skal de sammenlignes, og det skal påvises, at der o. 1690 blev fastlagt principper for fordelingen af kunsthåndværk, som varede frem til grundlæggelsen af dansk museumsvæsen i 1820'rne. Sagt med andre ord er emnet den dynastisk-nationale arv, eller udtrykt mere præcist, den kongelige arvegang og samlen 1520-1820. På den ene side Kunstkammeret som offentliggjort af Bente Gundestrup $1991^{1}$, på den anden side skatkammersamlingen på Rosenborg som behandlet af Gudmund Boesen og nærværende forfatter. $^{2}$

For tydelighedens skyld skal de to samlingstyper defineres.

Ved et skatkammer forstås en ophobning af kostbare genstande under fyrstens kontrol, der iscenesættes med pomp og pragt og kun er tilgængelig for de udvalgte få. Ved et Kunstkammer forstås en samling, hvis genstande 
154 indsamles og opstilles efter bestemte principper, der afspejler menneskets viden og forestillinger om omverdenen. Målet er belæring af en bredere offentlighed som udtrykt i Kunstkammerets opdeling i tematiske kamre, hvis genstande viste den besøgende et verdensbillede i miniature. Følgelig er de væsentligste forskelle, at Skatkammeret skal repræsentere og kan udgøre en kapitalreserve i nødstider, mens Kunstkammerets grundidé er strukturering og formidling af viden.

Akcepteres disse definitioner, kan den kongelige danske arv struktureres som en toleddet størrelse, opdelt i 1. en institutionellinje, kongemagtens samlinger (Rosenborg, Kunstkammeret, Det kgl. Bibliotek, Tøjhuset o.s.v.) og i 2. en privat linje, de kongeliges personlige kostbarheder og bohave, der udsmykkede deres gemakker og kunne nedarves inden for familien gennem generationer. Denne opdeling kan synes indlysende, men den har væsentlige konsekvenser, idet de kongeliges dødsboer var vigtige fødelinjer for de institutionelle samlinger. Og i denne sammenhæng ses en alvorlig kildemæssig skævhed: Kun én af valgkongerne har efterladt en bofortegnelse (Frederik I 1533), og med enevælden 1660 indførtes førstefødselsretten, hvorfor kongens bo aldrig blev opgjort. Dødsboer, der kan tjene som vejskilte på genstandenes færd til nutiden, eksisterer kun for enkedronninger og for ugifte prinsesser. Derved kommer kvinderne måske til at spille en større rolle $\mathrm{i}$ eftertiden end i samtiden.

\section{KunstKammeret}

\section{DET TYSKE SPROGOMRÅDE}

Kunstkamrene fik den mest rendyrkede form og den største udbredelse i det tyske sprogområde. Blandt de tidligste og bedst belyste var kunstkammeret i München ${ }^{3}$, hvor hertug Albrecht V 1563-67 lod en selvstændig bygning opføre, et fire-fløjet og tre-etages anlæg med stalde i stueetagen. I 1565 udgav hertugens rådgiver, lægen Samuel Quiccheberg, tillige det først kendte teoretiske skrift nord for Alperne om indretning af museer, "Inscriptiones vel tituli theatri amplissimi". Quicchebergs forbillede var florentineren Giulio $\mathrm{Ca}$ millos "Idea del Teatro" fra 1550, der videreførte den katolske kirkes helhedssyn, nu som nyplatonismens idé om verdensteatret, der lader mennesket ane det store i det små. I praksis fik Quicchebergs teori dog ikke den store indflydelse. For det første fik Kunstkammeret en særlig afdeling til genstande af ædelmetaller, bjergkrystal og halvædelsten, der blev samlet på skuebuffet'er i et hjørneværelse, hvis vægge prydedes af orientalske paradevåben. I umiddelbar tilknytning fandtes også samlingen af mønter. For det andet blev skulptursamlingen og biblioteket udskilt i en fælles bygning, Antiquarium, opført 1568-71. For det tredje båndlagde Albrecht $\mathrm{V}$ og hans hustru 17 pretiosa som "hus- og arveklenodier", der for altid skulle gå i arv til den ældste søn og ikke måtte sælges, pantsættes eller ændres. De blev opbevaret på slottet og kom til at danne grundstammen i det såkaldte kammergalleri, som kurfyrst Maximilian I lod indrette 1606-07. Hertil var der kun adgang med kurfyrstens personlige tilladelse, og her samledes nu mange af kunstkammerets udsøgte stykker, hvoraf flere blev båndlagt. I Maximilians sidste testamente fra 1641 nævnes kunstkammeret end ikke, fordi dets plads nu var overtaget af Skat- og kammergalleriet, der fra 1660'erne fik en fast plads i de fleste håndbøger om München.

Lignende tendenser ses hos Habsburgerne. Således fandtes en tilsvarende opsplitning af 
samlingerne hos ærkehertug Ferdinand II på Schloss Ambras i Tyrol. Også her var antiquarium og bibliotek udskilt. Kunstkammeret optog en af slottets fire fløje, våben de tre øvrige. De var opdelt $i$ et rustkammer, der havde afdelinger med turneringsudstyr, etnografica og tyrkiske våben, og i et heltekammer, der indeholdt kendte feltherrers buster og våben. Heltekammeret nød ærkehertugens særlige bevågenhed, hvorfor der udkom et trykt katalog 1601.

Antagelig var også kejser Rudolf II's kunstkammer i Prag et led i en større helhed. Det må huskes, at inventariet fra 1607-11, der kom for dagen i de Lichtensteinske samlinger 1947, kun omfatter godt halvdelen af kunstkammeret. Der er ikke fundet tilsvarende inventarier over Rudolf II's antikker og gemmer eller over hans skatkammer, skønt både kameer i pragtindfatninger og huskronen fra 1602, Rudolfs pièce de résistance er bevaret. Hvorom alt, 1612 flyttede kejser Mathias hovedstaden tilbage til Wien og lod et skat- og kunstkammer indrette på Hofburg, hvortil regalierne og udvalgte topstykker blev overført fra Prag. Senere tilkom båndlæggelser - som i München - og 1640-42 indrettedes et nyt galleri til denne samling, der nu kaldtes skatkammer. Pragten vistes i 13 skabe, hvoraf de sidste fem indeholdt bjergkrystal og halvædelsten samt - som klimaks - regalierne. Den samme stigningstakt sås på vinduesvæggens pilleborde, hvor f.eks. dynastiets stamklenodie penderede med regalierne. Endelig dækkedes endevæggen af et skab med tyrkiske våben. Som Rudolf Distelberger har konkluderet, forfulgte skatkammeret ikke et belærende eller æstetisk ideal. Målet var i stedet at guddommeliggøre kejseren ved at glorificere Habsburgerne som kristendommens forkæmpere mod Osmannerne. ${ }^{4}$
Lad os slutte med et blik på Sachsen, den 155 protestantiske modvægt til det katolske Bayern og den danske kongefamilies foretrukne ægteskabspartner med ialt fire giftermål 1548-1666. Kunstkammeret i Dresden havde til huse på slottet, hvor der også fandtes et skatkammer. Kunstkammeret blev grundlagt af kurfyrst August og talte ifølge inventariet fra 1587 knapt 10.000 genstande, hvoraf $75 \%$ havde teknisk karakter. Det afspejlede Sachsens førende rolle inden for europæisk bjergværks- og minedrift, men allerede Augusts søn, den ærgerrige Christian I, satsede anderledes. 1586-88 opførtes syd for slottet et rustkammer med stalde og rendebane, der havde forbillede i Philip II's i Madrid. Ud over våben og ridetøjer fandtes her klæder og etnografica, og rummene var udstyret med et anegalleri og med skænkeborde til skuesølv fra skatkammeret. I forsættelse heraf påbegyndtes i parken et lysthus med en grottesal, der skulle beklædes med sachsisk halvædelsten og tjene til udstilling af bjergkrystal. Dette lysthus blev aldrig fuldført, men følgen blev, at kunstkammeret først fik en større tilgang af artificialier i 1650 'erne. ${ }^{5}$

I et tilbageblik 1550-1650 fremstår udviklingen hos de førende hoffer i det tyske sprogområde som dobbeltsporet. På den ene side indførte kunstkamrene krav om viden og klassifikation i en verden præget af oversøisk ekspansion. På den anden side endte de bedste stykker hurtigt i skatkamrene. Måske var den væsentligste konsekvens en stigning $\mathrm{i}$ kunstnerisk udtryk og kostbarhed. For som bibelhumanismen lærte, har Herren udvalgt mennesket og givet det fornuftens lys. Og hvormed bedre ære sin Skaber end ved at forvandle naturalie til artefakt? Forbundet hermed var elementet af recreatio, fyrstens afslapning og eftertanke, enten ved drejebænken eller som 
JøRGEN HEIN

156 blot og bar samlerglæde. I baggrunden står Baldasare Castigliones ideal af hofmand, amatør og kender, der skal kunne konversere frit og utvungent om alt uden at lade sig tynge af fagmandens lærdom.

\section{Kongelige SAMLINGER I DANMARK I $523-\mathrm{I} 648$}

I 1523 tog Christian II de første Oldenborgeres regalier og pretiosa med i eksil. Efter reformationen blev regalier og skuesølv opbevaret i hvælvingen på Københavns Slot, mens kongens våben havde plads i flere rustkamre. I 1597 rejste Christian IV incognito til Dresden, hvor han beså rustkammeret, som han roste for dets gode orden. I 1598 startedes opførelsen afTøjhuset i København, hvor rustkamrene blev samlet og fortegnet i et særskilt inventarium, og 1599-1601 lod kongen et lysthus opføre i parken ved Frederiksborg slot. Det var Sparepenge, der med manieristisk ironi blev usædvanlig pragtfuldt udstyret. Sparepenge blev nedrevet 1720 , men to malerier viser dets ydre (fig. 1). Det havde en kælder, der tjente som stald, og to etager. Der findes intet inventarium. Vort kendskab skyldes dels tre rejseberetninger $(1617,1623$, 1642), dels tre bygningssyn, der kun anfører rummenes antal og navne $(1641,1645$, 1648). Den udførligste beskrivelse stammer fra 1623 og skyldes prins Christian af Anhalt. Hans omvisning startede i rustkammeret, der omfattede flere rum og indeholdt skyde- og blankvåben samt sadeltøjer. Særskilt bemærkede han sadelkammeret, hvor han især fremhæver en ungarnsk sadel med turkiser og Christian IV's ædelstensbesatte ridetøj med tilhørende kårde. Ligeledes nævner han en moskovitisk rustning, en gave fra zaren 1622 . Dernæst et kombinationsvåben med kårde og gevær. Til sidst noteres en større mængde fjer, lanser og andre turneringsredskaber. Efter rustkammeret så prinsen spisesalen, der havde malerier i loftet, en skænk med 120 bægre, som Christian IV havde vundet i ringridning samt en model af et bjergværk. Til sidst omtaler prinsen musikanterrummet i stueetagen, hvorfra lyden via rør i vægge og loft kunne stige op i spisesalen. ${ }^{6}$

Prinsen af Anhalts omvisning viser Sparepenge som en officiel skuesamling. Et rustkammer, der forenede paradevåben med tekniske nyskabelser og etnografica, antagelig primært arvestykker og gaver. Dernæst intime repræsentationslokaler, hvor turneringspræmier fremhævede værtens ridderlige færdigheder, mens bjergværket kunne lede samtalen hen på de norske fjelde, hvor der netop 1623 blev fundet sølv, alt imens det kongelige kapel, et af Europas bedste, fornøjede øret med liflige toner fra Musikanterstuen. Sparepenges våben skulle repræsentere og var ikke indsamlet med et encyclopædisk sigte. Da Sparepenge var Christian IV's eneste forsøg som samler, må man slutte, at denne aktivitet lå hans praktiske og resultatorienterede indstilling fjernt.

Det forklarer måske, at Christian IV gav sin ældste søn, den udvalgte prins Christian, råderet over Sparepenge, da han ægtede Magdalena Sibylla af Sachsen 1634. Berøvet politisk indflydelse fik tronfølgerparret en vis rolle som kulturmæcéner. De dyrkede musik og ballet og købte raderinger af Jordaens og Tenniers, Rubens og Rembrandt. ${ }^{7}$ I 1637 tilbød en kunsthandler tegninger til "Prinsens Kunstkammer", og i Sparepenges bygningssyn fra 1640'erne omtales musikanterstuen som kunstkammer. Det kan dog ikke have været særligt righoldigt, for tronfølgerparrets økonomi var elendig og der kendes kun en- 


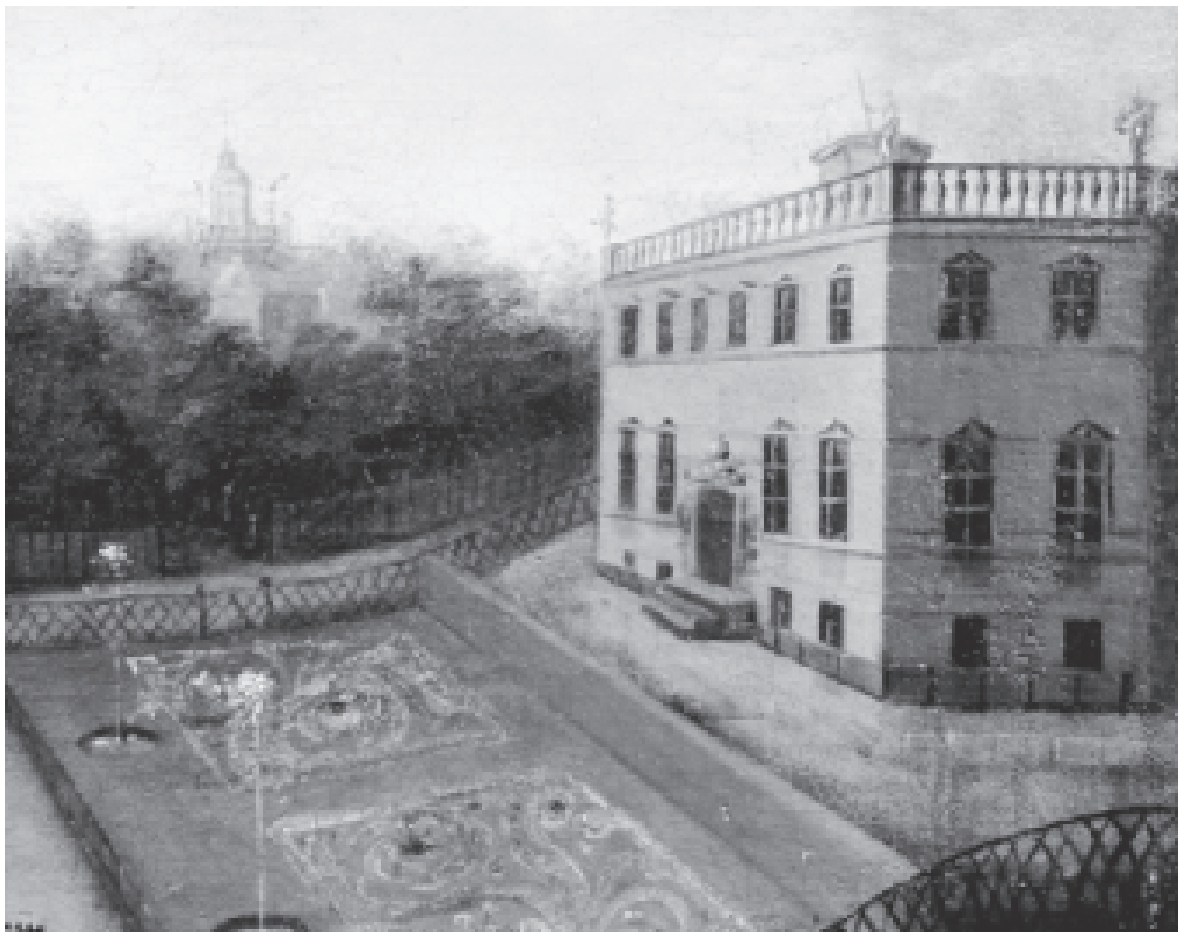

Fig. 1. Sparepenge. Detalje af anonymt maleri af Frederiksborgs Slot fra ca 1690. Det Nationalhistoriske Museum på Frederiksborg, inv. nr A 851. Foto: Hans Pedersen.

kelte anskaffelser. ${ }^{8}$ Kunstkammeret indgik da heller ikke i den officielle rundvisning 1642 , hvor gæsten i stedet fremhæver ridetøjerne, nu med ændringer udført til tronfølgerparrets bryllup 1634. Efter den udvalgte prins' død 1647 overlod Christian IV Sparepenge til hans yngre broder Frederik. Målet var at presse adelen til at vælge ham som tronfølger, og som konge lod Frederik III tilsyneladende Sparepenges kostbarheder forblive intakt, i al fald omtales de endnu i Jens Lauridsøns Wolfs Danmarksbeskrivelse fra 1654. Tillige blev der indrettet et værksted, hvor Peter Kalthoff fremstillede kunstbøsser. Først 1658, da Karl X Gustaf af Sverige førte sin hær over de til- frosne bælter og hastigt nærmede sig Frederiksborg, førtes Sparepenges kostbarheder til København.

\section{FREDERIK III'S SAMLINGER}

Sparepenges fortsatte eksistens har interesse, fordi Frederik III - samleren og kenderen blandt danske konger - primært huskes som grundlægger af Kunstkammeret. Dette synspunkt er imidlertid for snævert, også Det kongelige bibliotek og Rosenborg hører med $i$ helheden. Lad os derfor betragte trekløveret i den nævnte rækkefølge.

Kunstkammeret nævnes første gang 1650 
158 og lå i fortsættelse af kongens gemakker på Københavns Slot. Håndværkerregninger fra 1653 viser, at det nu omfattede flere rum, og hovedforøgelsen kom 1655 med købet af lægen Ole Worms kunstkammer, der talte 1663 numre, fortrinsvis naturalier. Kunstkammerets ældste inventarium stammer fra 1674 og viser en inddeling i otte tematiske rum eller kamre. Som helhed var samlingen præget af naturalier, mens kunsthåndværk var forholdsvist beskedent repræsenteret og især udmærkede sig ved drejede og skårne arbejder i organiske materialer. Også beholdningen af kunst synes sparsom, sikkert fordi mange skulpturer og malerier udsmykkede de kongelige slotte. Efter alt at dømme afspejler 1674 inventariet situationen ved Frederik III's død 1670, idet Christian V, der ikke delte sin lærde faders interesser, stort set standsede nyanskaffelser.

Medvirkende var også pladsmangel, for i 1650'erne var Frederik III begyndt at samle et bibliotek, og efter enevældens indførelse 1660 eksploderede tilgangen, alene 1662-65 tilkom henved 15.000 bind. I 1665 startede Frederik III derfor opførelsen af en ny treetages bygning over for Københavns Slot. Stue-etagen blev overladt til Tøjhuset, 1. etage til Det kongelige Bibliotek og 2. etage til Kunstkammeret. Biblioteket, hvis sal havde forbillede i kardinal Mazarins i Paris, blev opstillet umiddelbart efter bygningens fuldførelse $1673 .{ }^{9}$ Derimod kom indretningen af Kunstkammerets rum til at strække sig ind i 1680 'erne. Denne forsinkelse skyldtes utvivlsomt, at Frederik III døde 1670, før byggeriet var færdigt. Det bør derfor fremhæves, at vi ikke ved, om det var hans hensigt at forene kongehusets samlinger i den nye bygning. ${ }^{10}$ Spørgsmålet rejses, fordi Frederik III i 1660 'erne desuden begyndte at modernisere og at samle på Rosenborg. Grundstammen var Sparepenges kostbarheder, hvoraf hovedparten efter freden 1660 fik plads i to nyindrettede rustkamre i Store Tårn, hvortil kongen selv havde nøglen. I 1665-66 fulgte en opdeling i brugsvåben og i teknisk avancerede "kunstbøsser". Omtrent samtidig kan en lignende udvikling påvises for pretiosa og kunsthåndværk. Grundlaget er nyfundne arkivalier, dels regninger fra håndværkere, dels rejseberetninger $(1662,1668,1670) \mathrm{samt}$ ceremonimesterens protokol 1661-1671. De retter opmærksomheden mod 1. salens nordøstre tårnkammer, der fik en dekoration af lakerede kineserier 1665. I dette "Intianske" Kabinet gav Frederik III ialt 8 private audienser, hvorfor ambassadørerne især færdedes i 1. etagens nordlige halvdel. Og her nævner rejseberetningerne kunstværker og skabe med rariteter, primært det ædelstensbesatte ridetøj, nu udstillet på en udstoppet hest. Tillige f.eks. en statuette af kejser Leopold I, skåret i ét stykke stål af Gottfried Leygebe og indkøbt i Nürnberg 1665, og voksbuster af Ludvig XIV, hans hustru og elskerinde, pousseret af Antoine Benoist i Paris 1668. I fortsættelse heraf igangsatte Frederik III en modernisering af flere af stue-etagens rum. I sine sidste år samlede Frederik III således både til Kunstkammeret på Københavns Slot og til Rosenborg.

\section{Christian v's og Frederik iv's SAMLINGER}

Hvis det var Frederik III's agt at forene kongehusets samlinger i den nye bygning, fulgte Christian V ikke hans intentioner. Tværtom lod han Rosenborg udbygge til et egentligt skatkammer. Her tillader pladsen kun at skitsere denne udvikling, der kan følges i glimt, atter takket være nyfundne rejseberetninger 
(1671, 1674, 1677, 1692). Allerede 1670 nævntes de tre sølvløver på Den lange Sal, i 1671 tilkom tronstolen af narhvaltand og 1677 Rubens kendte maleri af Salomons Dom. Dermed havde enevoldskongens tronrum fået bibelsk symbolik, og på 1. salen omtaltes tillige guldhornet og to kabinetter med malerier. I 1681 indrettedes slotskælderen til gehejmearkivet fra Københavns Slot, og samtidig fulgte antagelig både regalierne og samlingen af guldmønter, hvis ældste inventarium blev udfærdiget netop 1681. Få år senere lod Christian V sine sejre forevige i 12 gobeliner til Den lange Sal, og 1686 tilgik topstykkerne fra det rige bo efter enkedronning Sophie Amalie. I 1692 nævnes for første gang såvel Regaliekammeret som et nyt rustkammer til Christian V's egne våben og til ridetøjer i slottets portbygning. Slutstenen på denne udvikling var Rosenborgs ældste inventarium fra 1696, der er det eneste, som både

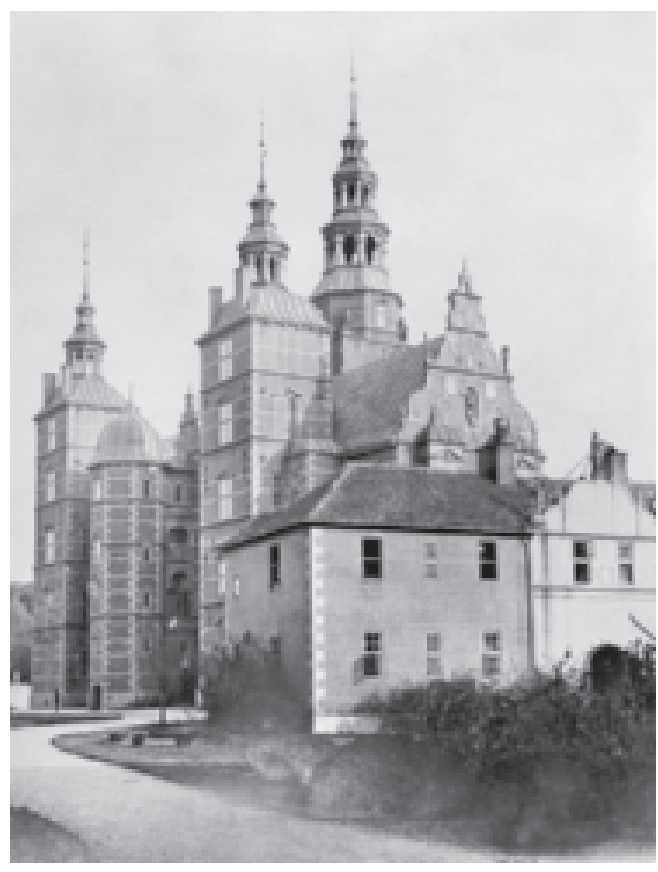

Fig. 2. Rosenborg, exterior og plan.

Rum 21: Den lange Sal med tronstol og sølvløver foran v. gavl. Rum 24:

Regaliekammeret med Gronne Kabinet t.h. Rum 22: Glaskabinettet. Rum 23:

Porcelenskabinettet.

I de tre øverste etager af Store Tarn:

Vabenkamre. I portbygningen foran h. gavl:

Sadel-og vaibenkamre.

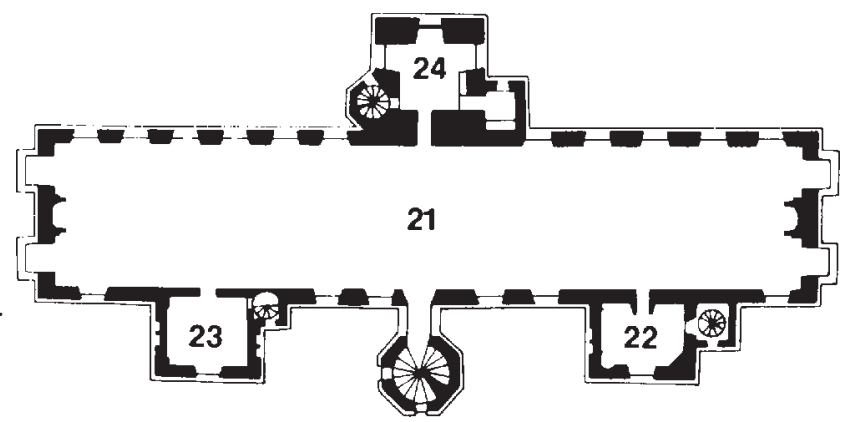

Fig. 3. Grundplan af Kunstkammeret.

Hovalergaarder.

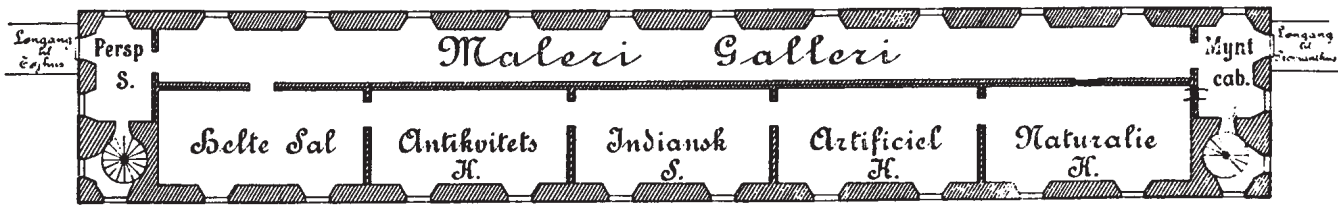


160 omfatter murskabene med regalierne hvortil kongen havde nøglen) og slottets øvrige indhold, der var slotsforvalterens ansvar. I Regaliekammeret anfører inventariet 174 pretiosa, i Grønne Kabinet 462 stykker kunsthåndværk, fortrinsvis af bjergkrystal og halvædelsten, i to kamre 167 miniaturer og 101 malerier samt i rustkamrene godt 900 våben foruden et antal ridetøjer (fig. 2).

I 1680'erne fuldførtes også Kunstkammerets opstilling i den nye bygning over for Københavns Slot (fig. 3). Det medførte en række tilgange fra de kongelige slotte, hvilket belyses af et nyt inventarium fra 1690, der tilkom som følge af et forvalterskifte. Ser vi på de med Rosenborg "konkurrerende" emneområder, anfører 1690 inventariet knapt 800 genstande under kunsthåndværk (2. Gemach/ Artificial-Kammer), 267 genstande under maleri/plastik (5-8. Gemach/Helden-, Galleri- Perspectiv- og Model-Kammeret) samt 119 våbn (4. Gemach/Antiquitet-Kammer). ${ }^{11}$ Allerede 1687 havde Christian V befalet Holger Jacobæus, læge og professor i historie og geografi, at udarbejde "en fuldkommen $\mathrm{Ca}$ talogum på Kunstkammeret”, der skulle oversættes til latin. Jacobæus afleverede sit manuskript 1689, men først 1696 udkom Museum Regium som et delvist illustreret katalog over et udvalg af Kunstkammerets genstande. I 1703 fulgte et supplement for tiden til Christian V's død 1699 og 1710 kom en forøget udgave, begge ved numismatikeren Johannes Laverentzen. De tre udgaver viser, hvad Christian V, Frederik IV og deres rådgivere, ønskede at præsentere for udlandet og afspejler samtidig deres bud på, hvad den dannede læser måtte forvente at finde.

I sin opbygning følger Museum Regium traditionen fra Ole Worms katalog i dens skelnen mellem naturalier og artificialier, dog med den forskel, at Museum Regium starter med mennesket og går baglæns i udvikling og kompleksitet og ender med sten og mineraler. Hvor Museum Wormianum kun havde anvendt knapt $12 \%$ af pladsen på artificialier, vægtede Museum Regium - som påpeget af både H. D. Schepelern og Flemming Steen Nielsen - langt mindre dækkende for Kunstkammerets bestand, idet naturalier er forholdsvist beskedent repræsenteret, mens artificialier, nordiske etnografica og især mønter og medailler optager hovedpladsen, også selvom guldmønterne, efter alt at dømme blev opbevaret på Rosenborg. ${ }^{12}$ Dette forhold ses allerede i 1696 udgaven, men forstærkes, således at mønter og medailler optager $60 \%$ af den trykte tekst i 1710. Samtidig udvides beskrivelsen af mange genstande, oftest med oplysninger af historisk karakter. ${ }^{13}$

Sluttelig - og væsentligt i nærværende sammenhæng - har 1710 udgaven under antikviteter et længere afsnit der henviser til Det kongelige Skatkammer på Rosenborg. ${ }^{14}$ Heri fremhæves først "de skønne rækker" af kameer og gemmer, dernæst de "gamle drikkekar" - skåle, fade og pokaler - af (bjerg)krystal og halvædelsten. Denne omtale må skyldes, at Museum Regiums udgivere har fundet det nødvendigt at give læseren en forklaring på, hvorfor Kunstkammerets bestand af artificialier i bjergkrystal og halvædelsten - renæssancens og manierismens genre par excellence - var beskeden.

Dermed udtrykker henvisningen en rollefordeling mellem de to samlinger. Spørger man, hvilke skillelinjer der lå til grund, er udgangspunktet Kunstkammerets til- og afgangslister, der er bevaret fra 1690 og følgelig tillader at følge bevægelserne mellem Kunstkammeret og Rosenborg. ${ }^{15}$ Interessant er især årene fra 1689-90, da Jacobæus afleverede sit 
manuskript og Kunstkammeret fik nyt inventarium, og frem til udarbejdelsen af Rosenborgs inventarium 1696. Betragter vi atter de "konkurrerende" emneområder, kunsthåndværk og maleri/plastik, ses en række afgange fra Rosenborg til Kunstkammeret. De er alle medtaget i Bente Gundestrups offentliggørelse af Kunstkammerets inventarium fra 1737 og forsynet med årstal, men ikke altid med afsender. Anonyme er således to afgange fra Rosenborg 1692 og 1695 af ialt 26 umonterede drejerarbejder - dåser, bægre og en enkelt stok. ${ }^{16}$ Til rest i Grønne Kabinet forblev kun 22 drejerarbejder, alle af elfenben og narhvaltand, hvoraf 12 var udgået i Rosenborgs næste inventarium 1718. Ser vi derimod på skairne arbejder af elfenben og narhvaltand, havde Grønne Kabinet hovedparten af pokaler, krus og bægre ${ }^{17}$, mens Kunstkammeret besad de fleste portrætmedailloner og relieffer. Ligeledes var genstande af andre organiske materialer som koral, næsehorn og træ, drejede eller skårne, stort set forbeholdt Kunstkammeret. Aforganiske materialer rummede Gronne Kabinet således primart elfenben og narhvaltand, fortrinsvis skärne pokaler, krus og bagre indfattet $i$ adelmetaller. ${ }^{18}$

Det modsatte billede møder os, hvis vi ser på mineraler, idet Kunstkammeret, fraregnet mineralprøver, imitationer af ædelsten og pietre dure indlægninger, kun havde 20 genstande af bjergkrystal og halvædelsten. ${ }^{19}$ Edle mineraler var klart reserveret Grønne Kabinet. Et forhold, der forstærkedes, da Kunstkammeret så sent som 1696 til Rosenborg afgav 39 kameer og gemmer ${ }^{20}$, knapt hele Artificialkammerets beholdning. ${ }^{21}$

Hertil kommer en anden forskel. I afgangene fra Rosenborg 1692 og 1695 indgik dels 8 elfenbensdåser, drejet af kronprins Frederik (IV) som nytårsgave til Christian V, dels et voksportræt, pousseret af kronprinsens halv161 broder, Christian Ulrik Gyldenløve. ${ }^{22}$ Antagelig afgav Rosenborg tillige Leonora Christina Ulfeldts kolorerede stik af Christian IV, som hun havde sendt Christian V med en bøn om frigivelse $1685 .{ }^{23}$ Endelig nævner Museum Regiums anden udgave fra 1710, at Frederik III's portræt af præsten i Jorck, der først nævnes på Kunstkammeret 1699, også kom fra Rosenborg. ${ }^{24}$ Kongelig "husflid" hørte hjemme på Kunstkammeret.

Skal man opsummere synes bevægelserne mellem Rosenborg og Kunstkammeret 169096 at have fulgt principper, hvorefter skårne og monterede elfenbener samt bjergkrystal og halvædelsten var forbeholdt skatkammeret (fig.4). Havde denne fordeling paralleller?

\section{TEORETISKE FORBILLEDER}

I løbet af 1600-tallet fremkaldte bl.a. den europæiske ekspansion og naturvidenskaberne en eksplosion af viden, der sprængte tanken om kunstkammerets universelle helhed og $\mathrm{i}$ stedet pegede mod specialsamlinger. ${ }^{25}$ Dermed fik forholdet mellem kunstkammer og skatkammer mindre interesse for den "museologiske" debat, hvorfor der her kun skal nævnes to bidrag, Johann Daniel Major's "Unvorgreiffliches Bedencken von Kunst- und Naturalien-Kammern insgemein" fra $1674^{26}$, og Leonhard Christoph Sturm's "RaritätenUnd-Naturalien-Kammern” fra $1707 .{ }^{27} \mathrm{~F}$ ælles er en historisk-filologisk gennemgang af benævnelserne for forskellige samlingstyper samt af begrebet "raritet", vel at mærke uden at der findes en entydig definition. ${ }^{28}$ Dernæst fastholdes en klassifikation af genstande efter materiale. Opstår der tvivl, bestemmer kunstkammerforvalteren, som Major og Sturm gør til en slags deus ex machina. Han bør derfor 
162 være lærd, ikke en "Schul Fuchsisch Gelehrte/oder Uhrmacher/Kunstdrechsler/oder welches noch ärger/Materialien-Krämer/Mahler/ Bildhauer/Kammer=Diener”. Til gengæld bør forvalteren have hjælp af en håndværker.

De mange ligheder mellem Major og Sturm skjuler en både personlig og tidstypisk forskel $\mathrm{i}$ interesse. For Major, der var læge, stod naturalierne i centrum. Derimod havde Sturm, ingeniør og lærer ved det ridderlige akademi i Wolfenbüttel, betydelig interesse for kunst. Således giver Sturm såvel en definition på et skatkammer som en opregning af, hvad det bør indeholde. Hans definition fortjener at anføres:

Schatz=Kammern sind solche Oerter .../darinnen alles das jenige auffbehalten wird/was man aus den kostbahrsten Materien als Edelgestein/Perlen/Gold/Silber/ Perlenmutter/Elffenbein/raren und kostbahren Holz und Lackwerck u. s. w. durch Kunst verfertiget oder zusammen setzet. Daher man diese Dinge leicht von den jeningen unterscheiden kann/welche eigentlich in Kunst=Kammern gehören. Weil man hier mehr auff die Kostbarkeit der Materie als auf die Kunst siehet/ dorten mehr auff die Kunst/ja fast allein/ohne absonderliche Absicht auff die Materie, ohne so weit die Arbeit dadurch desto kunstreicher zu halten ist/weil die Materie schwer arbeiten lässet.

Kort sagt funkler skatkammerets genstande ved materialernes kostbarhed, mens kunstkammerets stykker kendetegnes ved deres kunstfærdige forarbejdning. Interessant er også skatkammerets indhold, der nuancerer forskellene. Først nævnes et kammer med kameer og gemmer, der ifølge Sturm er så tidskrævende for stenskæreren at udføre, at kun fyrster kan betale. For mindre bemidlede kan mønter og medailler udgøre en erstatning. Dernæst følger et kammer med skabe i japansk lakarbejde med drikkekar, toiletred- skaber, røgelseskar, blomstervaser og thetøj i guld og ædelsten, orientalsk lak og porcelæn. I det næste kammer kommer skabe og kabinetter af europæisk arbejde, hvori udstilles ædelsten og perler samt kunsthåndværk i bjergkrystal og halvædelsten, rav og elfenben samt endelig guld, sølv og ure, som vel og mærke glimrer ved både den kunstneriske udførelse og materialets kostbarhed. Denne kombination betegner de såkaldte mirabilia, hvor menneskelig snilde har forvandlet naturalier til artificialier. Et sidste kammer med paradevåben, militaria og ridetøjer afslutter skatkammeret. Fyrstelige drejerarbejder henregner Sturm derimod under kunstkammerets artificialier, idet fyrsten ikke er kunstner af profession. ${ }^{29}$

Snarere end nyskabende må Sturms synspunkter ses som en opsummering af eksisterende tendenser, der i 1690'erne også havde fundet anvendelse i København. Det gælder såvel fremhævelsen af elfenben, herunder fordelingen af drejede versus skårne og indfattede arbejder, som især af bjergkrystal og halvædelsten, der netop bygger på både materialernes og forarbejdningens kostbarhed. En parallel er også placeringen af fyrstelig husflid på Kunstkammeret.

Denne fordeling fører til spørgsmålet om klassifikation. Som det fremgår af fig. 4, var kriterierne i Grønne Kabinet primært genstandenes materiale og sekundært deres brug, hvilket gav en symmetrisk-dekorativ opstilling. Dog har forskellen til Kunstkammeret næppe været stor, for i 1690 var den skarpe opdeling efter materiale og teknik, der kendetegner de 18 grupper af artificialier i Kunstkammerets inventarium fra 1737, endnu ikke gennemført. I 1737 fordeltes de 18 grupperinger på 7 skabe samt en ophængning. I 1690 ses i stedet en ophængning samt 4 skabe, der 


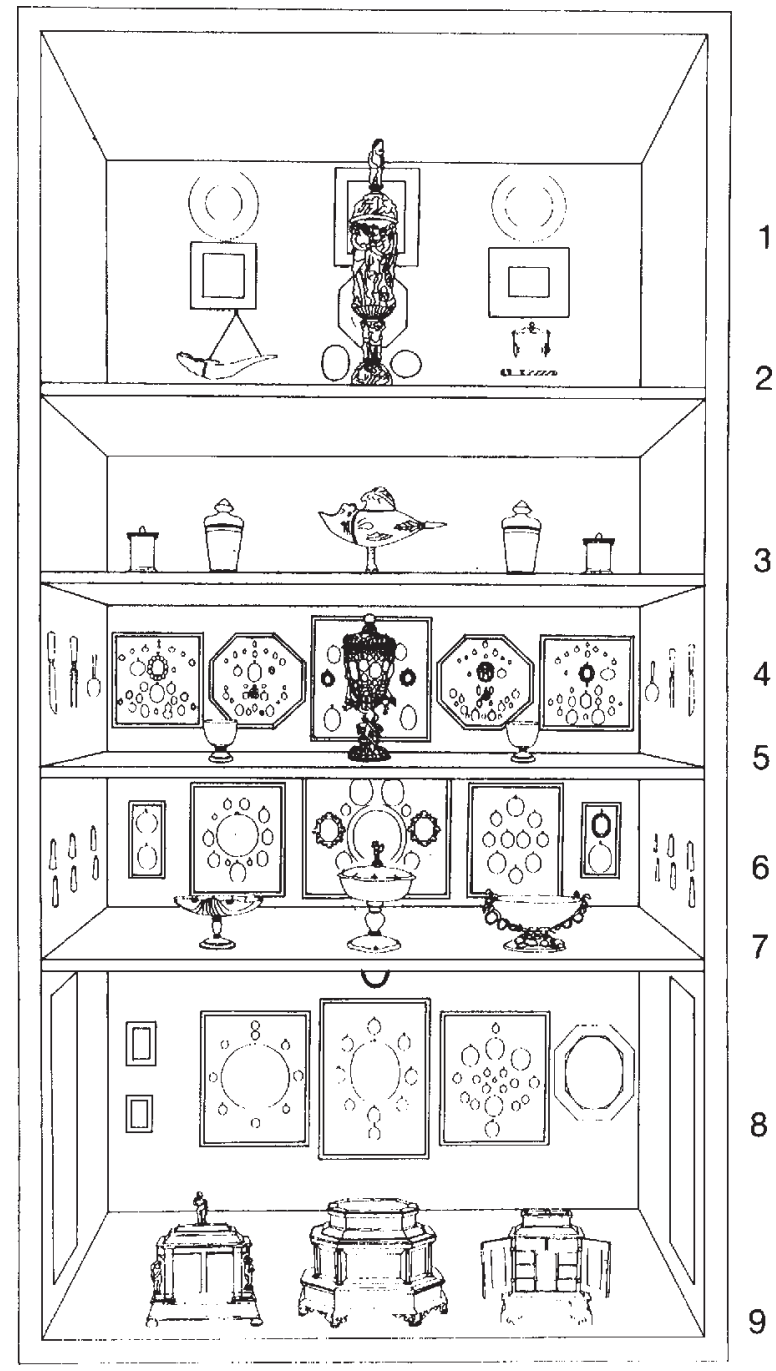

1

2

3

4

5

6

7

Fig. 4.

Vegskabet i Gronne Kabinet 1718.

8

1-2 Elfenben, narhvaltand.

3 Bjergkrystal.

4 Smykker, kameer og bestik.

5 Halvadelsten.

6 Miniatureportratter og bestik.

7 Halvadelsten.

98 Miniatureportratter og gemmer.

9 Elfenben. blander genstande af forskellige materialer og teknikker, således at de hyppigst forekommende går igen i samtlige skabe. Følgelig har udstillingen været anlagt efter symmetrisk-dekorative principper, der skabte ro i mangfoldigheden. ${ }^{30}$ Antagelig skyldtes den øgede sys- tematik i 1737 de tre udgaver af Museum Regium.

I valget af personale ses derimod en forskel. Sturms krav om, at kunstkammerforvalteren burde være lærd, blev fulgt til ca. 1710 , først af akademisk uddannede in- 
164 spektører og senere af Museum Regiums udgivere. Tilsvarende var den daglige leder håndværker, oftest kunstdrejer eller maler. ${ }^{31}$ Modsat startede Rosenborgs fire slotsforvaltere 1681-1781 alle som kongens livkarl, page eller kammertjener. Afgørende var ikke faglige kvalifikationer, men monarkens tillid. Også i tilgængelighed var der forskel. Mens både Kunstkammeret og Rosenborgs gemakker var åbne for omvisninger mod betaling, krævede det "besynderlig" tilladelse at se regalierne frem til 1922.

I et tilbageblik afspejler de mange initiativer og flytninger i 1680'erne og 1690'erne nederlaget i Den skånske Krig, der forpligtede fremtiden til revanche mod Sverige. Dermed forsvandt også de økonomiske muligheder for at opføre en ny residens, og i stedet søgte den unge enevælde nu prestige ved at ordne de kongelige samlinger. Dels ved færdigindretningen af Frederik III's "kulturhus" og udgivelsen af Museum Regium, dels ved anlæggelsen af et skatkammer og af nye rustkamre på Rosenborg. For kunsthåndværk blev udfaldet den ovennævnte fordelingsnøgle: Skatkammeret fik fortrinsret til skåret og monteret elfenben, bjergkrystal og halvædelsten; Kunstkammeret til drejet elfenben og øvrige organiske materialer.

\section{Perspektiver}

Disse skillelinjer holdt sig stort set til grundlæggelsen af dansk museumsvæsen i 1820'rne. Det kan undre, fordi den lange fred efter 1720 og opførelsen af Christiansborg Slot 1740 skabte nye muligheder. Lad os derfor kort skitsere udviklingen, der synes tre-delt.

I 1713 erobrede Frederik IV Slesvig-Holsten-Gottorp og lod hertugernes private samling overføre til Rosenborg. Her kom forde- lingsnøglen i brug. Bjergkrystal, halvædelsten og skårne elfenbener, henved 180 genstande, tilgik Grønne Kabinet. Drejet elfenben, andre organiske materialer og det øvrige, mindst 235 stykker, indgik derimod i et privat kunstkammer, som Frederik IV lod indrette i Vinterstuen. ${ }^{32}$ Omtrent samtidig blev de to øvrige tårnrum på riddersalsetagen, modsat Regaliekammeret og Grønne Kabinet (fig. 2), indrettet som glas- og porcelænskabinetter. Det illustrerer Frederik IV's prioritering af skatkammersamlingen frem for Kunstkammeret.

I 1740'rne lod Frederik V sin bedstefaders private kunstkammer i Vinterstuen opløse. Han udtog nogle af genstandene til sin egen samling af pretiosa og kunsthåndværk på Christiansborg, overlod andre til en lignende samling, der blev båndlagt til dronningens brug, og sendte resten til Kunstkammeret. ${ }^{33}$ Efter Frederik V's død 1766 fulgte en lignende deling af hans samling mellem Rosenborg og Kunstkammeret Det gentog sig, da det, der blev reddet ved Christiansborg Slots brand 1794, blev fordelt $1797 .^{34}$

En tilsvarende fordeling ses tillige ved tilgangene fra dødsboerne efter samtlige enkedronninger og ugifte prinsesser $(1714,1735$, 1743, 1770, 1783). Dog efterlod enkedronning Sophie Magdalene sig så stort et bo, at megen bjergkrystal og halvædelsten af beskeden kvalitet tilgik Kunstkammeret. ${ }^{35}$

Bruddet kom med oprettelsen af en specialsamling, Den kongelige Mønt- \& Medaillesamling, 1781. I samlingen, der fik lokaler på Rosenborgs første etage, forenedes guldmønterne fra Regaliekammeret med Kunstkammerets store bestand. Ifølge kommissoriet skulle den nye samling imidlertid også omfatte "antiquer" og "udskaarne Steene", og 1785 afgav Grønne Kabinet sine kameer og 
gemmer, ialt 196 genstande. Glyptik havde imidlertid ikke numismatikernes interesse, og allerede 1791 blev kameer og gemmer sendt videre. Dog ikke retur til Grønne Kabinet, men til Kunstkammeret. ${ }^{36}$ Manden bag denne afgørelse var Johan Bülow, kronprins Frederik (VI)'s magtfulde hofmarskal, der netop havde ladet sig udnævne til chef for Kunstkammeret. Samtidig udvirkede Bülow en fuldmagt til at måtte "udsøge tienlige Stykker" på de kongelige slotte til Kunstkammeret, og i februar 1793 foreslog han at overføre regalierne til Christiansborg og Rosenborgs øvrige samlinger til Kunstkammeret. Omfanget af Bülows planer og hans politiske opbakning er ukendt, og hans bestræbelser løb ud i sandet, da han faldt i unåde sommeren 1793. ${ }^{37}$ Bülows forslag viser imidlertid, at enevælden, blot få år efter Den franske Revolution, var bevidst om behovet for en nyordning af de kongelige samlinger, idet museumstanken nu var blevet spydspids i aristokratiets og borgerskabets kamp om politisk indflydelse og kulturel identitet. I stedet kom Englandskrigene og tabet af Norge til at betyde en udsættelse til 1820'erne, da Kunstkammeret blev opløst i specialmuseer og tanken om at gøre Rosenborg til et museum for kongehuset tog form.

\section{Nationalmuseet og ROSENBorg}

Grundlæggelsen af dansk museumsvæsen er behandlet andetsteds, hvorfor der her kun skal fremdrages to aspekter. I 1822 tilstillede lederen, overhofmarskal Adam Wilhelm Hauch, den til formålet nedsatte kommission et oplæg. Heri spurgte han

om ikke alle de af Guld og Sølv forarbejdede Sager, som nu befindes paa Kunstkammeret, i Forening med de derværende ægte og andre slebne Stene og Agather, forarbejdede som Skaale og Vaser m. m. [de ovennævnte kameer og gemmer], rigtigst bleve at forene med de lignende Ting, som allerede befindes paa Rosenborg, for samme Steds at opbevares og der at udgiøre en Samling for sig selv.

Til gengæld skulle Rosenborg afgive til Kunstkammeret alle de Ting, som egentlig er Kunstsager, de i Elfenben udskaarne Basrelieffer o.s.v. saa vel som alle Oldsager.

Samlingen paa Kunstkammeret og paa Rosenborg skulde efter min Meening med eet Ord bestemmes og skiælnes fra hinanden derved, at alt det, som nu haves i begge Samlingerne og som kan henregnes til egentlige Kunstgienstande, blive at opbevare paa Kunstkammeret, hvorimod alle de Sager, der mere have deres Værdi fra de Materialer eller de Materier, hvoraf de vare forfærdigede, end fra Kunstsiden, skulde opbevares paa Rosenborg Slot. ${ }^{38}$

Hauchs udgangspunkt var således den "gamle" fordelingsnøgle, men udfaldet blev det modsatte. I 1823-24 afgav Rosenborg hovedparten af elfenben, bjergkrystal og halvædelsten, men fik til gengæld flere hundrede genstande med kongelig tilknytning fra Kunstkammeret, herunder husflidsstykkerne. Det var med denne bestand af kunsthåndværk, suppleret af mindre arbejder fra Regaliekammeret og af Glaskammeret, at Rosenborg åbnede som museum 1838. Da udstillingen bestod af interiører, der følger kongerækken, kom forøgelserne væsentligst til at bestå af Frederik VI's og Christian VIII's personlige effekter.

Modsat fik Kunstkammerets afløser, Det kongelige Kunstmuseum, den største og fineste koncentration af kunsthåndværk, der er set i Danmark. Det afspejledes i nye inventarier, hvis beskrivelser formidlede samtidens faglige viden om genstandene i modsætning til tidligere tiders knappe karakteristik, hvis formål blot havde været genkendelighed. Den- 
166 ne tendens styrkedes i 1840'rne, da arkæologen C.J. Thomsen nyordnede samlingen til "Museet for Skulptur og Kunstflid". Resultatet blev en forløber for de senere kunstindustrimuseer, der viste udviklingsrækker inden for europæisk kunsthåndværk, omend i den vante symmetrisk-dekorative opstilling. ${ }^{39}$ Dermed havde dansk guldalder vist internationalt niveau, men genstandenes vandringer var ikke slut. Et sidste led må med for at belyse senere begrebsforvirring.

Baggrunden var enevældens afskaffelse og folkestyrets indførelse 1848 samtidig som de nationale spændinger mellem dansk og tysk blev udløst, først i det slevig-holstenske oprør 1848, der endte med dansk sejr, dernæst i krigen med Preussen og Østrig, som førte til hertugdømmernes afståelse 1864. I samme periode havde C.J. Thomsen begyndt opbygningen af det senere Nationalmuseum i Prinsens Palæ-Etnografisk Samling åbnede 1846, Antikcabinettet 1851 og Oldnordisk Museum 1856. Imidlertid sparede det nye folkestyre på kulturen. Til gengæld skulle en række af de kongelige slotte og deres indbo nu overgå til statsejendom, og ved den barnløse Frederik VII's død, ville tronen, meget mod hans vilje, overgå til den Glücksborgske sidegren, der havde ry som tyskvenlig og udemokratisk, hvorfor der ikke var nogen til at sikre dens fremtidige interesser.

Parallelt hermed var Rosenborg blevet et fideicommis, "udeleligt og arveligt fra konge til konge" 1854, og 1858 blev arkæologen J.J.A. Worsaae, der stod i modsætning til C.J. Thomsen men nød amatørarkæologen Frederik VII's gunst, udnævnt til leder. Ifølge Worsaaes erindringer stod hans mål klare fra starten. Dansk museumsvæsen burde afspejle civilisationens fremadskriden: Etnografisk Samling skulle vise fremmede folkeslag,
Antikcabinettet den klassiske oldtid og et kommende museum for maleri og skulptur den senere udvikling. Sideløbende skulle Danmarks kulturhistorie deles mellem $\mathrm{Mu}$ seet for Nordisk Oldtid frem til Christian IV's tronbestigelse 1588, hvor Rosenborg skulle tage over, eventuelt fulgt af et fremtidigt museum for folkestyrets tidsalder efter 1848. I forbindelse hermed foreslog Worsaae bygningen af et nyt nationalmuseum på Livgardens eksercerplads, i umiddelbar tilknytning til Rosenborg, således at slottet ville blive "juvelen i Danmmarks krone".

Afgørende for Worsaaes planer blev Frederiksborg Slots brand 1859, der føltes som en national ulykke. Før asken var kold, udvirkedes Worsaae et kongeligt reskript, der gav ham ret til at udtage til Rosenborg fra samtlige kongelige slotte - en klar parallel til Johans Bülows tilladelse 1791. ${ }^{40}$ Følgen blev store overførsler af møbler og malerier. Dernæst kom nederlaget i krigen 1864, som medførte en konservativ reaktion, og 1866 blev Worsaae, i forståelse med det nye kongehus og mod C.J. Thomsens indstilling, leder af Etnografisk Samling og Museet for Nordiske Oldsager. Året efter fulgte nedlæggelsen af Museet for Skulptur og Kunstflid, og ved den følgende deling med Oldnordisk Museum fik Rosenborg løvens part, over 650 genstande. Ikke kun returneredes hovedparten af den bjergkrystal og halvædelsten, der var blevet afgivet fra Grønne Kabinet 1823-24. Nu fulgte det bedste af Kunstkammerets drejerarbejder, relieffer og statuetter, uanset organisk materiale. ${ }^{41}$ Ved at definere Rosenborg som kulturhistorisk nationalmuseum gjorde Worsaae skatkammeret til arvtager af Kunstkammerets kunsthåndværk. Og da regalierne forsat var skjult bag lås og slå og bjergkrystal og halvædelsten blandedes med Kunstkammerets 
genstande, skabtes en overbevisende helhed. For udenlandske fagfolk blev Worsaaes Rosenborg "ein vortreffliches Bild einer alten Kunstkammer”. Karakteristikken, der skyldes den tyske kunsthistoriker Julius von Schlosser, blev fremsat i hans bestseller "Die Kunst und Wunderkammern der Spätrenaissance" fra 1908. Billedet dækker hvad Schlosser så, men ikke historien forud. Det bliver opgaven for den kommende katalog over Rosenborgs skatkammersamling.

\section{SUMMARY}

Status versus Learning? Schatzkammer or Kunstkammer? In the 1660s Danish absolutism built up a treasure collection at Rosenborg Castle and a Kunstkammer opposite Copenhagen Castle. both of which contained applied art. It is the aim of this paper to trace this overlapping and to show that around 1690 principles were established for a division of objects that resulted in the two institutions becoming mutually supplementary. In other words the subject is royal heritage and royal collecting 1520-1920.

A comparison calls for definitions. A 'treasure collection' refers to an accumulation of valuable objects that is arranged with pomp and splendour. Three characteristics should be highlighted: the Prince or his official has the key to the collec;tion, the objects are partially entailed as inalienable property, and viewing requires the permission of the sovereign. A 'Kunstkammer' in this context means a collection of objects that are classified and displayed according to distinct principles which reflect human knowledge and theories about the surrounding world. Consequently the treasury represents and can provide, in time of emergency, a capital reserve, whereas the fundamental concept of the Kunstkammer is the structuring and imparting of knowledge as expressed in the publication of catalogues.

The Kunstkammer achieved its purest form and its most widespread distribution in the German-speaking 167 area. It has to be stressed, however, that most were only parts of a system of interdependent collections and that in many cases the Kunstkammer existed for only a short time. From around 1600 the most significant of them gave up their best objects to treasure collections as happened in Munich and in Vienna. Expressed in very simplified terms, the treasure collection underwent a Renaissance in the Baroque period. This development also had consequences for Denmark. Christian IV (1588-1648) had a pavilion built in the grounds of Frederiksborg Palace between 1599-1601. It was named Sparepenge and became an official display-collection, an armoury combining ornate weapons and technical innovations with tournament equipment and ethnographica. In 1634 the king handed over Sparepenge to the Crown Prince, and in the 1640s one of the rooms is referred to as a Kunstkammer, however sparingly furnished. In 1647 on the death of the Crown Prince, Christian IV defined Sparepenge as inalienable "Crown treasure" and had it transferred to the future Frederik III (1648-70). Apparently the new king, who founded the Kunstkamrner at Copenhagen Castle in 1650, left Sparepenge intact, but on the eve of the Swedish invasion in 1658 Sparepenge's treasures were rescued and taken to Rosenborg, where they formed the core of a new collection. When Frederik III started the construction of a new building to house the Kunstkammer, library and armoury in 1665, he collected applied art for both the Kunstkammer and for Rosenborg.

If it had been Frederik III's intention to unite all royal collections in the new building, Christian V (1670-99) extended Rosenborg into a genuine treasure collection including the regalia. When the Kunstkammer finally moved into the new building, a dividing line was established, as proved by the accession and de-accession lists of the Kunstkarnmer 1689-1696. Roughly speaking vessels of rock crystal and hardstones as well as cameos and intaglios were reserved for Rosenborg. Ivory and narwhal tusk, mostly in the form of carved goblets, tankards and beakers with moun- 
168 tings of precious metal were also the preserve of Rosenborg, while turned objects and works of other organic materials were placed in the Kunstkamrner. Finally, royal handicraft belonged in the Kunstkamrner.

In retrospect three things should be noted. First that these dividing lines paralleled the theoretical model put forward by Leonhard Christoph Sturm in his treatise on "Raritäten-UndNaturalien-Kammern" from 1707. Secondly that they remained virtually intact until 1785 , when the cameos and intaglios were transferred to the new Royal Collection of Coins and Medals. Thirdly that they also formed the basis for the initial plans when the Kunstkammer was dissolved in the 1820s and the early Danish Museums established. The outcome, however, was not to establish clear divisions for distribution, but quite the opposite.

Between 1823-24 Rosenborg handed over most of its ivory, rock crystal and hardstones, but received in turn several hundred objects with royal associations from the Kunstkammer, including the royal handicraft items. They formed the bulk of the centents when Rosenborg opened as a museum belonging to the royal family in 1838. In contrast the successor to the Kunstkammer, the Royal Art Museum, held the largest and finest concentration of applied art works ever seen in Denmark. In 1864 Denmark's defeat to Bismark's Prussia was followed by a political reaction that heralded new museum plans. Now Rosenborg was defined as a national museum for the period 1588-1848 and the Royal Art Museum was closed down. As a consequence Rosenborg received not only most of the rock crystal and hardstone which had been handed ovcr in 182324, but also the best of the Kunstkammer's tumed works, reliefs and statuettes, regardless of whether or not they were of organic material. As the regalia were still unaccessible to the public, the ensuing mixture of objects may explain the description of Rosenborg as "ein vortreffliches Bild einer alten Kunstkammer", which was put forward by the German art historian Julius von Schlosser in his bestseller "Die Kunst und Wunderkammern der Spätrenaissance" from 1908.

\section{Noter}

- Denne artikel er en bearbejdet udgave af forelæsning afholdt på Museumshøjskolens museologiske forelæsninger tirsdag den 7. marts 2000.

1. Gundestrup, Bente (red.): Det kongelige danske Kunstkammer 1737 / The Royal Danish Kunstkammer 1737, I-II, 1991.

2. Boesen, Gudmund: Danmarks Riges Regalier, 1986 og Royal Arms at Rosenborg, I-II, 1956. Hein, Jørgen: ”Das Grüne Kabinett im Schloss Rosenborg - Schatzkammer oder RaritätenKabinett?" i Andreas Grote: Macrocosmos in Microcosmo. Zur Geschichte des Sammelns 1450-1850, Opladen 1994, 323-337, og Krise og Kroning. Frederik III's regalier 1648, 1998.

3. Seelig, Lorenz: "Die Münchener Kunstkammer". Jahrbuch der bayerischen Denkmalpflege, Band 40, München 1990, 101-103.

4. Scheicher, Elisabeth og Distelberger, Rudolf $\mathrm{i}$ Impey, Oliver \& MacGregor, Arthur (red.): The Origins of Museums, Oxford 1985, 29-38 og 3946. Beket Bukovinská i Eliska Fuciková \& al.: Rudolf II and Prague, London 1997, 199-208.

5. Syndram, Dirk: Die Schatzkammer August des Starken, Leipzig 1999, 22-39, og Hoyer, Eva Maria: Sächsischer Serpentin, Leipzig 1995, $71-$ 72, 90-91.

6. Krause, G. (udg): Tagebuch Christian des Jüngeren Fürst zu Anhalt, Leipzig 1858, 95-101.

7. Otto Andrup: "Kunstnere ved den udvalgte Prins Christians Hof", Kunstmuseets Aarsskrift, 1920, 96-110.

8. Victor Hermansen: "Den udvalgte Prins og Rariteterne. Et Stykke Museumshistorie", Kulturminder, Ny rk., III, 1960, 16-44.

9. Ilsøe, Harald: Det kongelige Bibliotek i støbeskeen, 1, 1999, 35, 190. Helge Gamrath i Hvidt, Kristian, Ellehøj, Svend \& Norn, Otto: Christiansborg slot, I, 1975, 126-130.

10. Hermansen, Victor: "Fra Kunstkammer til Antik-Cabinet", i Antikcabinettet, 1951, 29. 
11. Inv. over Det kgl. Kunst og Raritet Kammer 1690-98 (afskrift ved John Bundgaard Rasmussen 1985), fol. 46-72, 343-357, 92 nr. 73 - 97 nr. 150.

12. Jørgen Steen: Den kongelige Mønt- og Medaillesamling 1781-1981, 14-18.

13. Schepelern, H. D.: "Natural Philosophers and Princely Collectors: Worm, Paludanus and the Gottorp and Copenhagen Collections" i Impey 1985, 121-127. Flemming Steen Nielsen: Fra fyrsteligt raritetskabinet til offentligt museum. En undersogelse af museumsarbejdet og dets rolle i kulturkampen i Danmark under enevalden. Specialeopgave ved Københavns Universitet 1988, 26-31.

14. Part III, Section II, No. 58.

15. NM Grønne arkivkasser nr. 5: Afskrift af Inv. 1690 og Tilgangsliste 1691-1733 sikkert udført til Brug ved Aflev. 1737.

16. NM Grønne arkivkasser nr. 18: Afskrift af Grodtschillings Manuale 1690 - c. 1737. Gundestrup 1991 I 759/225-226, 761/254-263; 766/328-335, 757/352; 771/406, 771/421-423.

17. Af de 10 krus og pokaler i Kunstkammerets 1737 inventarium, tilgik 5 så sent som 1735, antagelig fra prinsesse Sophie Hedevigs bo jf. Gundestrup 1991, I, 756/170-171, 757/180, 757/184 (fejlidentifikation)-185 og 755/163-166, 755/168.

18. Undtagelser er 2 bægre af hvalros, 3 figurer af koral, 1 kårdefæste af næsehorn, 1 statuette og 1 relief af buksbom.

19. 7 stykker kirkeinventar af bjergkrystal jf. Gundestrup 1991, II, 827/53, 827/72, 830/91, 830/ 98-99 og 12 genstande af halvædelsten jf. samme I, 743/13, 742/52, 747/55-57, 748/65, 750/ 89-91.

20. NM Grønne arkivkasser nr 19. "Concept til inventarium for Kunstkammeret 1690", fol. 7-8. De 39 kameer og gemmer er ikke anført på afgangslisten 1690-98 i inv. 1690 fol. 529-530.

21. Gundestrup 1991 I 738/150, 739/158, 748/61.

22. Ibid. I, 759/225-226, 774/477.
23. Ibid. 796/765 jf. Kladde til 1737 inventariet,

NM Grønne arkivkasser nr. 18, fol. 131

24. MR 1710,II, I, 86 jf. Gundestrup 1991, I, 645/ 70.

25. Christoph Becker: Vom Raritäten-Kabinett zur Sammlung als Institution. Zur Sammeln und Ordnen im Zeitalter der Aufklärung. Deutsche Hochschulschriften 1103, Frankfurt 1996, 3-43.

26. Genoptrykt i Michael Bernhard Valentini: Museum Museorum oder vollständige Schau Bühne.

2. Edition. Frankfurt am Main 1714, I. Anhang, $1-76$.

27. L.C. Sturm: Des geöffneten Ritterplatzes, worinnen die vornehmste ritterlich Wissenschaften, III, Raritäten-Und-Naturalien-Kammern, Hamburg 1707.

28. J.D. Major, op. cit., IV-V kap., 5-11. L.C. Sturm, op. cit. III kap., 15-18.

29. Sturm, op. cit., 9.-11. kammer, stk. 2-6, 36-39, 50-51.

30. Smml. Gundestrup 1991 I 213-417 med Kunstkammer inv. 1690, fol. 46-72.

31. Gundestrup 1991, I, XIX-XX. Liisberg 1897 87-99.

32. Bencard, Mogens \& Hein, Jørgen: "Die Preziosen des Gottorfer Herzogshauses. Eine private Kunstkammer" i Drees, Jan \& al.: Gottorf im Glanz des Barock, II: Die Kunstkammer, Schleswig 1997, 49-57, 162-224. Hertil Rosenborgs inv. 1718 fol. 294-360.18.

33. Hein; Jørgen: "Frederik V som samler. Kunsthåndværk fra det første Christiansborg. Om privat og offentligt i enevældens kongelige arv" i Jeppesen, Hans (et al): Søfart-Politik-Identitet. Festskrift til Ole Feldbæk, 1996, 245-266.

34. Rosenborgs arkiv: Protokol over det, der blev reddet ved Christiansborg Slots brand 1794 .

35. Inv. 1775 fol. 244-263 nr. 596, 612, 615-616, 624, 629-660, 672-677, 680-682, 684, 688, 699-702, 728, 785-818.

36. Jensen 1981, 48. 
37. RA DK Det kgl. Kunstkammer 39: 1775-1793 Inventarieregnskaber, forestillinger og korrespondance m. v. Hertil Sorø Akademis Bibliotek. Johan Bulows Manuskriptsamling. 18 Hoffet. 84 E 2: "Udtog af Rosenborg Slots Inventario, 1793.

38. Andrup, Otto: Den kongelige Samling på Rosenborg gennem hundrede Aar, I, 1933, 49.

39. Thomsen, C.J.: Kort Udsigt over Det kongelige Kunstmusaums forskjellige Afdelinger, 1844, 26-28 nr. 52-55, 29-32 nr. 60, 36 nr. 70.

40. Worsaae, J.J.A.: Optegnelser om Rosenborg-Samlingen i 25 Aar, 1886, 9, 23-29, 31, 52-57 samt Rosenborgs brevarkiv 14.4.1860.
41. Ifølge Worsaaes tilgangsliste i Rosenborgs arkiv skulle der udarbejdes en opgørelse over genstandene i henhold til "Cultusministeriets Resolution af 23de Dec. 1868". Dette synes aldrig at være sket. Tallet bygger på Rosenborgs inventarium fra 1877, der kun dækker udstillingen, samt en liste fra ét af magasinerne.

Jørgen Hein är museumsinspektør vid Rosenborg. Adr: De Danske Kongers kronologiske Samling,

Rosenborg, ØsterVoldgade $4 \mathrm{~A}$

DK-1350 Kobenhavn K

E-post: jh@dkks.dk

\section{ATT SLÅ VAKT OM TVIVLET I EN VÄRLD FULL AV AUKTORITET}

Carl-Axel Moberg (1915-1987) skrev sin "klassiker" i Svenska Museer när han fortfarande var museilektor vid Statens Historiska Museum i Stockholm. Samma år, alltså 1957, utnämns han till chef för Arkeologiska museet i Göteborg. Åren 1960-1979 verkar han som professor i arkeologi vid universitetet där. Och som sådan också som en viktig introduktör i Norden för angloamerikanska och franska idéströmningar. Carl-Axel Moberg var internationalist, humanist och stor inspiratör för yngre kolleger. Som en röd tråd i hans vetenskapliga och litterära författarskap löper respekten för de mänskliga rättigheterna och för det personliga ansvaret som forskare och pedagog.

”Pedagogik och propaganda är två populära ord som numera i allra högsta grad ingår i museimäns ordförråd", lyder hans inledning. Detta ordförråd, 45 år senare, innehåller förvisso pedagogik, numera och i allt högre grad uttryckt som det livslånga lärandet. Propagandan har kanske inte längre ett eget ministerium. Men väl som i Berlusconis Italien ett helt kabinett. Och de Olympiska Spelen är propaganda i kolossalformat.

Det mediavridna samfundet, som förändrat museernas roll, förstärker samtidigt det principiellt angelägna i vad Moberg skrev. För honom är museerna först och främst förmedlare av kunskap - arkeologiskt i ordets egentliga bemärkelse är ett museum ej genom att det äger ett arkeologiskt material, utan endast i den mån dess verksamhet har med arkeologisk vetenskap att göra.

När Moberg nämner 1943 och Historiska museet åsyftar han den stora utställningen Tiotusen år $i$ Sverige. En utställning som nu vore värd en egen mässa.

En utställning är som en dialog mellan museet och besökaren. Men, menade Moberg, den som ställer ut får inte gömma sig bakom museets anonymitet - den aktuella frågan om curatorer.

Och som vågor som slår mot en strand - avsaknaden av god och öppen museikritik, då som nu.

... att slå vakt om det fruktbärande tvivlet i en värld full av auktoritet.

I mitt litterära husapotek finns sju böcker. En av dem är Carl-Axel Mobergs Den långa stubinen (1977), en annan Tage Danielssons Tankar frän roten (1975). De båda samhällsbyggarna förenas i sin starka tro på tvivlet.

"Tvivlet är all kunskaps grund", skrev den sistnämnde. I döda poeters sällskap vidgas perspektiven och fördjupas framtidstron.

Erik Hofrén 


\title{
OM PEDAGOGIK OCH PROPAGANDA I ARKEOLOGISKA MUSEER
}

\author{
Carl-Axel Moberg
}

Pedagogik och propaganda är två populära ord. De ingår båda $i$ allra högsta grad $i$ museimäns ordförråd. Ofta verkar det som om de ansägs beteckna en och samma sak $i$ musealt arbete - eller åtminstone varandra ytterst närliggande ting. Men noga besett bör de snarare kunna användas för att ge namn àt två djupt olika tendenser Skillnaden gäller syftet och inriktningen - inte de tekniska medlen och förfaringssätten.

Det är i den religiösa föreställningsvärlden som ordet propaganda ursprungligen har fătt sin särskilda betydelse. Jesuitorden lär ha givit det dess innebörd av utbredandet av den enda "rätta" tron med hjälp av alla medel som leder till framgång. Som utbredandets korrelat medföljer undanträngandet av de "oriktiga" åskådningarna - den medvetna horisontförträngningen i förlitande på auktoritetens omdöme.

Pedagogik har med skolning och uppfostran att göra. Den är den rådande uppfattningens tjänare - men auktoritativ är den endast om den sistnämnda är auktoritativ. De följande sidorna är skrivna i den övertygelsen, att $v i$ är ense om att uppfostran och undervisning bör vara motsatsen till auktoritativ, ge hjälp till mångsidig orientering, öva förmågan till kritiskt bedömande, vidga perspektiven i stället för att tränga hop dem. Den som har helt och hållet annan uppfattning har intet att hämta här, utan kan avbryta läsningen nu.
Om man använder ordet pedagogik i sådan mening, räcker inte den välkända hart när standardiserade beskrivningen på vad som gör ett museum "pedagogiskt": överskådlighet, rikliga och lättförståeliga förklaringar, sammanhängande linje, attsamlingen verkligen berättar, har något att lära ut. Ty de museala uttrycksmedlen kan lika väl användas både i pedagogiskt och propagandistiskt syfte. En välgjord utställning som har alla dessa egenskaper kan vara god propaganda, men dålig pedagogik - eller omvänt. Huruvida den är god inte bara tekniskt utan också ur pedagogisk synpunkt, betingas av vad den lär ut.

Låt oss granska dessa frågor något närmare. Vi skall hålla oss till arkeologiska museer. Även arkeologiska museer har visserligen ofta i större eller mindre utsträckning funktionen att liksom konstmuseerna ge estetiska upplevelser. Men här är det fråga om deras primära egenskaper såsom kunskapsförmedlare. Ar- 
172 keologiskt i ordets egentliga betydelse är ett museum ej genom att det äger ett arkeologiskt material, utan endast i den mån dess verksamhet har med arkeologisk vetenskap att göra.

Det skulle inte vara svårt att nämna ganska talrika exempel på vad som ligger på ena eller andra sidan om gränsen mellan pedagogik och propaganda i sådana museer. $\mathrm{Om}$ något av de enstaka exempel som här skall ges, inte är konstruerat, utan hämtats från (delvis redan försvunna) detaljer i Historiska museet i Stockholm, är det inte därför att detta skulle intaga någon markerad särställning ur dessa synpunkter, annat än därigenom att 1943 års djärva och genom positiva och negativa erfarenheter fruktbärande utställningsexperiment ställde så många frågor på sin spets. Men författaren är tacksam för att där ha fått tillfälle att skaffa sig någon erfarenhet av hur museibesökare av olika slag arbetar - inte minst läraren eller den intresserade skoleleven med anteckningsbok i handen. Det är intressant, men ibland också skrämmande, att bevittna vilken förkrossande auktoritet sådana besökare kan tillmäta de upplysningar, som museet lämnar.

Lättast att urskilja är givetvis den politiska eller på annat sätt i dessa sammanhang osakliga propagandan, sådan som den ofta manifesterat sig, såsom i många tyska museers nationalistiska presentation av Tysklands och dess grannländers forntid, för att ta ett exempel utifrån.

Det är emellertid inte sådana företeelser som politisk propaganda i museer, vilka man främst vill fästa uppmärksamheten på här. Detta är förhållandevis obehövligt eftersom de är relativt lättare att urskilja. Mindre iögonenfallande är vad man skulle vilja benämna vetenskaplig propaganda - den som föreligger, när en uppfattning, ett betraktelsesätt tillåts verka på besökaren under markant gynnsammare för- utsättningar än andra. Vetenskaplig propaganda skulle det till exempel vara, om man i en museistad upplystes om att "vid denna tidpunkt invandrade från söder ett folk av boskapsskötande nomader, vilka talade ett indoeuropeiskt språk". Det är acceptabel pedagogik, om besökaren får veta att "det finns olika meningar om båtyxkulturens ursprung och i vilken utsträckning den uppbars av invandrande folk; enligt en uppfattning finns det skäl för att dess bärare skulle ha talat ett indoeuropeiskt språk". Men det skulle vara bättre pedagogik, om man fick en något fylligare orientering om viktigare olika uppfattningar.

På liknande sätt kan man till den pedagogiska sidan föra en etikett, där det står att den första jordbrukskulturen sannolikt fördes hit av invandrare, medan exempelvis uppgifter om namn och regeringsår för den kung i ett svenskt forntidsrike, som skulle ligga $i$ en bestämd järnåldersgrav, otvivelaktigt skulle höra hemma i propagandan - liksom en oreserverad upplysning att "under den sista istiden levde människor på en smal isfri kustremsa $\mathrm{i}$ Nordskandinavien".

Det sistnämnda skulle på sätt och vis också kunna gälla en presentation av en svårläst och debatterad runinskrift med endast ett av de översättningsförslag, som föreligger, utan ett uttryckligt ord om att det finns en diskussion och alternativ. En antydan härom kan dock anses vara gjord om översättaren namnges: "Enligt N.N. översättning"; den uppmärksamme besökaren har då åtminstone fått en chans att ana att andra runologer översatt på annat sätt.

Över huvud taget skulle naturligtvis inte litet av god pedagogisk effekt kunna vinnas med så enkla medel som ett $\mathrm{i}$ ögonen fallande omnämnande, att "denna utställning är ordnad av N.N. och återger hans personliga 
uppfattning av de svårlösta och mycket diskuterade frågorna kring detta slag av fynd".

Det kan naturligtvis vara av olika och stundom mycket respektabla skäl, som vissa även karakteristiska delar av det arkeologiska materialet från en epok eller en kulturgrupp inte visas för museipubliken, utan endast ett speciellt urval av vissa arter av det framhävs. Det kan dock röra sig om missriktad estetik - de många "fula" sakerna får inte störa de färre "vackra" eller "slående" (kanske med veckotidningsutgivarnas vanliga försvar "att publiken vill ha det så”). Men det kan framför allt också vara ett mer eller mindre medvetet hävdande av en forskningsriktnings övertygelse att endast det utvalda materialet är av större intresse; och i så fall kan man ha att göra med vetenskaplig propaganda. Det är under alla omständigheter inte god museal pedagogik, bland annat därför att det kan inge besökare förakt för sådana "vardagsfynd" som de kanske själva skulle kunna hjälpa till med att skydda eller bärga, om blott museet ej tillslutit deras ögon.

De nämnda exemplen kan illustrera, hur museimannen i varje fas av sitt arbete kan ställas inför valet mellan den propagandistiska eller den pedagogiska vägen. Propagandistisk ensidighet kan åstadkommas både genom tendentiöst urval av det material, som skall ställas ut; genom sättet att sammanställa; genom förtigande eller undanskjutande av avvikande åsikter, när vad som utställs skall förklaras, skriftligen på etiketter eller i vägledningar etc., muntligen vid demonstrationer eller i föredrag, radio etc. Hit hör på sätt och vis även den medvetna "urlakningen", intill innehållslöshet, av vad som meddelas, därför att man vill undvika "controversial matters" - för att inte behöva ta ställning. "Man kan inte oroa eller förvirra publiken med sådant." Resultatet kan, medvetet eller omedvetet, bli en ur pedagogisk synpunkt otillräcklig redovisning 173 för underlaget till vad som framställes. Den som löper störst risk att förfalla till dessa olika slag av ensidighet är nog ofta den, som talar om fynden. En museilektor kan lätt bli propagandist i stället för pedagog.

Det avgörande för vad som sker i museet i dessa avseenden är naturligtvis museimannens personliga läggning och erfarenhet. Bakgrunden till en propagandistisk utställning kan vara otillräcklig orientering hos utställaren något som borde beaktas i den mer eller mindre eviga diskussionen om vetenskapligt contra musealt i utbildningen. Ty med grundligare vetenskaplig förankring kan följa större respekt för problemen, och mera intresse för att ställa museipubliken inför dem. Valet mellan pedagogisk eller propagandistisk utställningslinje bör inte vara svårt, om man anser att bland det, som museet skall verka för, även ingår sådant som orientering om och respekt för det vetenskapliga vardagsarbetet, för strävan till objektivitet, för tålamod och vilja att gå till grunden med frågor - och för modet att deklarera när man ej kunnat nå den. Här ligger en väsentlig del av de arkeologiska museernas tillfälle att göra en insats i centrala delar av bildningsarbetet - med möjlighet att verka långt utöver de speciellt arkeologiska intressegränserna.

$\mathrm{Nu}$ vet visserligan alla, att det finns även högt förtjänta forskare, som är främmande för tanken att någon annan än de själva skulle kunna ha rätt. Är de museimän blir deras utställningar automatiskt propaganda för deras egna uppfattningar; andras bekämpas aktivt eller, framför allt, förtigs.

Även om sådana arkeologers skrifter ger uttryck för samma självhävdande inställning, är detta inte på samma sätt ödesdigert som deras museala verksamhet kan bli. Här spelar 
174 kritiken in. De vet av erfarenhet, hur de än ogillar det, att deras skrifter kan komma att kritiseras. Också när de yttrar sig muntligen kan de möta motinlägg. Men i sitt museum är en sådan arkeolog ganska trygg. Det finns nästan ingen på innehållet $\mathrm{i}$ utställningar inriktad, öppen museikritik. Och sådana propagandaåtgärder, som består i tendentiös gallring av det material, som visas för allmänheten, är dessutom ofta nästan omärkliga annat än för fackmän med mycket grundlig orientering i fynden. Om någon kritik skulle riktas mot vad museet förkunnar, kan den avspisas med det vanliga motskälet att " visst vet vi att det är mer invecklat än det framställs här, och att det finns olika åsikter, men man kan inte göra det så inkrånglat för icke-fackmän”. Man erinrar sig en äldre statsvetenskapares sarkastiska anmärkning när han i en polemik ställdes inför samma argument. Den löd ungefär så här: "Jag har för min del aldrig kunnat inse, varför någonting skulle bli lättare att förstå genom att framställas annorlunda än det verkligen förhåller sig”. Naturligtvis har varje museum lov att söka välja sin publik, välja vem det vill vända sig till. Men de principiella kraven på god pedagogik lär förbli desamma vilka besökare valet än faller på.

Det går inte att generellt säga vad "ett museum skall vara till”. Men ett vetenskapligt

"...att vara en nödvändig främling. Man kan ha skäl att känna sig som främling: när man har till yrke att forska om människor som man inte längre kan göra något som helst för; när det finns så mycket att göra bland de levande och för de kommande.

Men vi levande är för få och för speciella. Studium bara av oss skulle ge för snäv bild av arten människans möjligheter och omöjligheter.

Nuet är så kort, ger för korta perspektiv; och vi behöver så långa tidsperspektiv för eftertanke framåt. arbetande arkeologiskt museum har uppenbarligen till uppgift att verka för mera vetande. Dess samlingar skall dels användas till att skaffa fram mer vetande, genom att materialet utökas samt hålls tillgängligt för fri forskning $\mathrm{i}$ original och genom publikationer och genom att det bearbetas. Dels skall de utnyttjas för att sprida vetande. Medlen därtill utställande av fynden och förklaring av dem genom skrift, bild och talat ord - kan användas i olika riktning, pedagogiskt eller propagandistiskt.

Propagandavägen är otvivelaktigt den breda vägen, lättast att gå, den som kan göras mest inbringande i besöksstatistiken, för den som menar att det är viktigare hur många personer som går in i museet än hur mycket vetande som passerar ut ur det.

De som vill gå den väg som här kallats den pedagogiska, ställs inför den stora och stundom till synes hopplösa uppgiften att bidra till att hålla frågandet vid makt, att påminna om problemen, om begränsningen i vetandets möjlighet, att slå vakt om det fruktbärande tvivlet $i$ en värld full av auktoritet - av politisk, religiös, pedagogisk, teknisk-naturvetenskaplig "vi-vet-det-inställning".

Dessa sidor har skrivits för att hävda, icke att den vägen är den enda, men att den är en väg som förtjänar en viss - propaganda...

Det kan bli lättare om vi släpper in tanken på och kunskapen om de gångna tiderna i vårt medvetande.

Och sist men inte minst: de levandes föreställningar om de döda är viktiga beståndsdelar i de levandes ideologi och politiska syn; därför är kritisk belysning av dessa föreställningar och deras verklighetsförankring inte betydelselös.

Den kritiske belysaren av sådant är en nödvändig främling."

Carl-Axel Moberg (Den långa stubinen, 1977) 


\title{
The Deceased
}

\section{AS AN Issue of Museum Ethics:}

\section{Finnish Examples}

\author{
Janne Vilkuna
}

In Finland, museums differ from the archives maintained by authorities and from free copy libraries which preserve all material printed. In the case of museums, the only types of material automatically preserved are prehistoric objects and animals protected by law that have been found dead. Regarding all the other material to be preserved, the museum is forced to make choices: either keep it or dispose of it. This selective process is closely bound up with the exercise of power and raises numerous ethical questions which need to be considered, as a whole, in museum work and environmental protection. A key aspect for museums operating according to the community and environment centred principles of the so-called new museology, is awareness of ethical issues.

The general meeting of the International Council of Museums in Buenos Aires in 1986 agreed on the ICOM Code of Professional Ethics. The code was amended in 2001. Well aware of the work done on the international code, the Finnish national committee of ICOM started preparing a national code of ethics as early as 1983, and the work was completed in 1987. After circulating a proposal for comments, the code was published in 1990. ${ }^{1}$ It is entitled (in English) Guidelines The Ethical Principles of Museum Work.

In the same year, the Guidelines were discussed in the Annual Meeting of the Finnish Museums Association. The topic was intro- duced by Professor Hannu-Tapani Klami (1945-2002). Dealing with the basic concept of ethics, he aptly stated that "We have to choose a course of action, which, on weighing its pros and cons, is considered the best one, that is, the one that carries the highest expectation value". Klami defined the fundamental goal of museum work by stating that "We must maximise [as far as our resources allow] the possibility for future people to acquaint themselves with the past". ${ }^{2}$

The museum staff therefore has a moral responsibility towards people and societies in the past, the present and the future. Thus inherent in museum work are a number of 
176 interesting but complicated ethical and moral issues. In this presentation, I will use the attitude to the dead, the deceased, as an example.

\section{ELSEWHERE AND IN FINLAND}

For centuries, people have been offered the opportunity to be horrified at the sight of the remains of the dead put on display. Probably the best known sites are located in Italy. The Capuchin catacombs and the skeletons and "mummies" displayed at S. Maria della Concezione in Rome and in Palermo at the Convento dei Cappuccini have been, and still are, famous tourist attractions. ${ }^{3}$

Something similar can be found in every country, and Finland is no exception. Probably the most successful crowd puller can be found in the stone church in Keminmaa (NW Finland) which dates back to the 16 th century. In the chancel of the church the mummified body of Nikolaus Rungius, the minister of the parish, lies ready to be viewed. ${ }^{4}$ What has made the site all the more exciting is the popular tradition explaining the mummification. According to the story, the minister is said to have proclaimed that his body would not rot until sin had vanished from his parish. The body of Rungius is not unique since numerous bodies buried in Finnish churches or cemetery chapels are in rather good physical condition; but they are not put on display.

In Paris, anatomical exhibits of animals and human beings were put on display as early as the 18 th century. The purpose, however, was to teach anatomy. These exhibits (écorché) were prepared by Honore Fragonard (17321799), who experimented by putting the bodies in various positions, e.g. a rider on horse- back and Samson with the jawbone of an ass in his hand. ${ }^{5}$

These exhibits may have served to inspire Gunther von Hagens, professor of anatomy in Heidelberg, who developed a new method of preparation in the 1970s. What was new in von Hagens' activity, was that he became a sculptor; but instead of carving marble, he carved bodies. Naturally the people whose bodies were used had given their permission. From the autumn of 1997 until the spring of 1998, the Landesmuseum für Technik und Arbeit in Mannheim housed an exhibition of anatomic preparations or parts thereof named Körperwelten. The exhibits were made by von Hagens. The exhibition aroused a lot of interest, but it was only around the time of the opening of the exhibition Die Macht des Alters in Deutsches Historisches Museum in Berlin in the autumn of the same year 1998, that the discussion really began. The exhibition consisted of works by 40 artists, including von Hagens. One of his works, Muskelmann mit Haut, represents a walking man who has been skinned in such a way that he is covered with muscles and tendons. The man is lifting up his skin as if he were taking off his coat. ${ }^{6}$ Even though the deceased had offered their bodies for artistic use, it is still worthwhile posing the question: How far do a person's rights over his/her body extend? I wonder how the children or the grandchildren of the deceased as a work of art feel, as they peer at their parents or grandparents in an exhibition?

The discussion around von Hagens is not exactly of current interest in Finland - at least not yet - since Finnish legislation does not permit the use or reuse of dead people as a source of art. The relation to the deceased has, first and foremost, been defined in two regu- 
lations: the Law on Antiquities (295/1963) and the Health Protection Statute (1286/ 1994). The law regulating the protection of and research into antiquities and monuments states that "Monuments serve as protected memories of the previous settlements and history of Finland". Included in the law is a list of monuments, of which two subsections deal with pre-Christian and Christian graves.

According to subsection 2 the following are protected: pre-Christian graves and graveyards, including those of which there are no visible traces on the ground ... (and subsection 6) ancient, abandoned castles, castle hills, forts, fortresses, embankments and moats and their remains, the ruins of churches, chapels, monasteries and other outstanding buildings and ancient graveyards which are not taken care of by the church.

But there is no specific mention in the law of bodies, although the notion of grave can be assumed to include the bodies. Section 40 of the Health Protection Statute deals with burying, and in its first paragraph states that "The body of the deceased must be buried immediately in an appropriate coffin or its equivalent, or cremated in a crematorium". The body can be left unburied only if the body or parts of it are to be used for medical purposes, either in the treatment of another person or for medical education. The section of the existing criminal law that deals with the desecration of bodies and graves dates from 1889 and its meaning is clear: "Any person who without permission takes a body or parts of it from a grave, or disposes, hides or dismembers an unburied body, vandalises the body or causes damage to a grave or commits mischief, is to be sentenced to imprisonment for up to one year, or to pay a fine".
Archaeology, though still in its infancy, had been assigned a national task in the 19th century around the time of the above mentioned regulation. It is no wonder that the exhuming of bodies had to be properly motivated. Johan Reinhold Aspelin, who was appointed the first state antiquarian in 1884, explained that "For the benefit of science, and in spite of the problems, the bones of the deceased are to be invited out of the ground to testify to the prehistoric past as much as they can".

The declaration of human rights ratified at the general meeting of the United Nations in 1948 does not mention the rights that people have over their own bodies or those of their relatives or someone else. However in the above mentioned ICOM Code of Ethics the issue is raised in Chapter 6.6. Human Remains and Material of Sacred Significance ${ }^{8}$ :

"Collections of human remains and material of sacred significance should be housed securely and respectfully, and carefully maintained as archival collections in scholarly institutions. It should be available for legitimate study on request. Research on such material, its housing, care and use (exhibition, replication and publication) must be accomplished in a manner consistent with professional standards and the interests and beliefs of members of the community, ethnic or religious groups from which the objects originated. When sensitive material is used in interpretive exhibits, this must be done with great tact and with respect for the feelings of human dignity held by all peoples. Requests for removal from public display of human remains or material of sacred significance must be addressed expeditiously with respect and sensitivity. Requests for the return of such material should be addressed similarly. $\mathrm{Mu}-$ seum policies should clearly define the pro- 
178 cess for responding to such requests (see also 4.4 above)."

The position of indigenous peoples was widely discussed in the 1960s. As a result of this publicity, work was begun on a declaration in 1970 under the supervision of the UN. To date it has not resulted in any such document. However, in the United States of America, the cultural claims of indigenous peoples led to the passing of a law regulating their rights in 1990 which also takes a stand on human remains':

"Native American Graves Protection and Repatriation Act (NAGPRA) ... assigns ownership and control of Native American cultural items, human remains, and associated funerary objects to Native Americans. It also establishes requirements for the treatment of Native American human remains and sacred or cultural objects found on Federal land. This act further provides for the protection, inventory, and repatriation of Native American cultural items, human remains, and associated funerary objects."

The issue has also become topical in other countries and remains as such. Primarily the discussion has revolved around the differences of opinion between researchers and indigenous peoples, which culminate in the question: who, in the end, has a right to the deceased from the preceding centuries and millennia? ${ }^{10}$

The Banyoles City Museum in Spain gained publicity in Europe in the 1990s as a result of the display of the mummified body of a Botswanian tribal chief. Before the Olympics in Barcelona in the spring of 1992, many Africans objected to the display and announced that they would not participate in the Olympics unless the body was removed from the exhibition. In a similar fashion, in 1998, the Inuit of Greenland laid claim to a body displayed in the Museum of Natural History in Rotterdam. They demanded that the body, which had been taken to the museum in the 19th century by Dutch sailors, should be returned to Greenland for burial."

In Finland, bodies or body parts have not been regarded as an issue; nor did the 1987 national ICOM "Guidelines" contain any of the above mentioned passages included in the ICOM Code of Ethics. Are bodies and body parts then entirely unproblematic in Finnish museums? I will approach this topic in the light of four examples.

\section{The skeleton of Matti Haapoja, THE MURDERER}

Matti Haapoja (1845-1895), bom in Ylistaro in Southern Ostrobothnia, killed his first victim in 1869. This manslaughter was the beginning of recurring imprisonments and escapes, during which he killed some ten people in Finland and Siberia. Popular stories, ballads and the press turned him into a mythical mass-murderer, who took his own life in 1895 by hanging himself in his prison cell. At that time the Institute of Anatomy at the University of Helsinki had the right to receive the bodies of prisoners for the purposes of the teaching and practising of medicine. This is why Haapoja's body was not buried but instead had the tissues removed from the body, while the prepared skeleton ended up in the university's collection.

In 1926, the Centre for Crime Investigation was set up. It operated under the supervision of the Ministry of the Interior and also organised courses in investigation. The Police Museum was established in 1937 to support this task. The museum material was ac- 


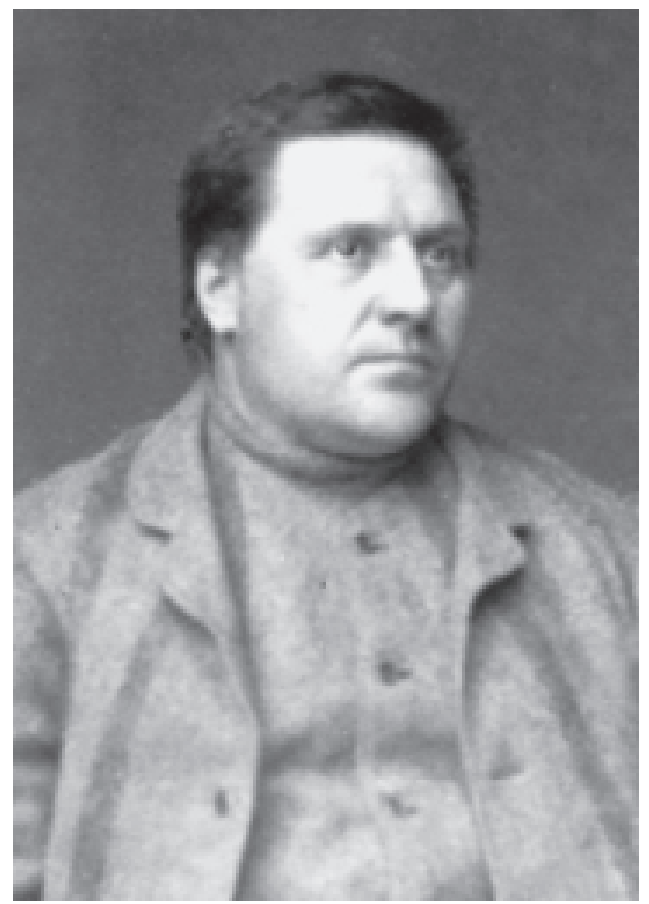

Mass-murderer Matti Haapoja (1845-1895). The National Board of Antiquities.

cumulated as a result of the centre's activity, or was donated to it by the police or other authorities. In March 1938, the chief of police, Kosti Vasa asked the council of the University of Helsinki for permission to add the skeleton of the famous criminal, housed in the Institute of Anatomy, to the collection of the Police Museum. The council agreed but on one condition: the head of the Institute maintained the right to carry out scientific experiments on the skeleton, if this was considered necessary. The skeleton was added to the collection in June 1938, and for decades it occupied a central place in the exhibition.

The Centre for Crime Investigation later became the Central Criminal Police. In 1994 its office was also moved from Helsinki to Tikkurila in Vantaa. The Criminological Museum (fi. Rikosmuseo) was moved into a new building and its image badly needed updating: what used to be a pedagogical exhibition had become a cabinet of curiosities. What was needed was an exhibition that would tell the history of the Finnish crime investigation and the nation's police force, arranged according to current museological criteria. Haapoja's skeleton was not compatible with this concept - something that the people working with probation and aftercare had also noticed. To deal with this state of affairs, the Central Criminal Police, the University of Helsinki, the Ministry of Justice, the Church Governors and Ylistaro parish began to co-operate and what happened was a miracle: the human remains that had once been turned into a museum object were transformed once again into a deceased on the road from Helsinki to Ylistaro on the 16th September, 1995. The deceased was committed to eternal rest in the old Ylistaro graveyard. ${ }^{12}$

\section{THE SKULLS OF THE SAAMI}

The Swede Olof Rudbeck carried out the first anthropological measurements of the Saami people as early as the 17 th century. In the course of the centuries and parallel with the development of racial theories, the interest in the Saami became all the more fevered and all self-respecting universities longed for physical exhibits of the Saami in their anthropological collections. The first Saami skulls in the collections of the University of Helsinki, were obtained in 1878. The skulls were supplied by M. Solitander a mining engineer, who was a member of an expedition panning for 
gold in the River Ivalo, Lapland. He was given the authority to carry out excavations, and under his supervision, 103 skulls were dug up on the island of Vanhahautuumaasaari in Inan. The next, more extensive dig on the same island, was conducted in 1934, when Professor of Anatomy, Väinö Lassila, acquired a further 49 skulls, with the authorisation of the Ministry of Education. ${ }^{13}$

As the importance of the racial theories diminished, the desire to maintain skull collections was partly lost. As a result of Jouni Ilmari Jomppanen, a member of the parish council, bringing the issue to discussion, the university returned 95 Saami skulls to Inari in June 1995. Bishop Olavi Rimpilainen committed the skulls, which had been placed in two coffins, to eternal rest. However, over one thousand skulls remained in the collections of departments of Forensic Medicine and Anatomy. In order to decide on the fate of these skulls, a consultative committee was set up in 1995 consisting of experts of law, medicine, theology, history, paleontology, the $\mathrm{Na}$ tional Board of Antiquities and the Ministry of Education. ${ }^{14}$

\section{Bishop Henrik's elbow bone and Queen Karin MÅsdotter's TOOTH}

During the renovation of the Cathedral of Turku ( $\AA \mathrm{bo}$ ) in the 1930 s, a bundle of relics stored in the church found their way to the National Museum in Helsinki. Among other items, the collection included 12 small relics, all of which were kept in a wooden box especially made for this purpose. One of the twelve was the elbow bone of Bishop Henrik, the first bishop of Finland, who was killed in 1156 with an axe wielded by a peasant. The relic

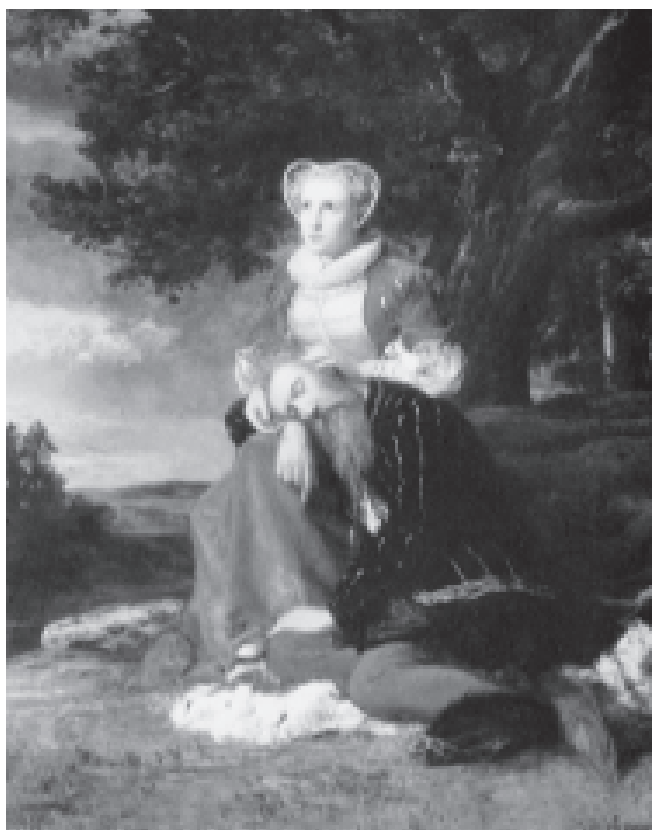

The painting "Erik XIV and Karin Månsdotter" by Erik Johan Löfgren, which he finished in Paris in 1864. The portrait had been commissioned by a remarkable donor in Sortavala, the Assisting Judge and Councillor of State Herman Hallonblad and his wife Elisabet, who bequeathed the painting to the Fine Arts Association of Finland. Collections of the Finnish National Gallery.

was lent by the National Board of Antiquities to the catholic parish of Bishop Henrik in Helsinki for a mass. In 2000 it was loaned to the parish for five years. It was decided that the precious relic should be put on display behind bullet-proof glass in a silver box on the church altar. The Evangelical Lutheran church of Turku has also laid claim to the relic, demanding that it should be returned to the Cathedral of Turku. ${ }^{15}$

The collections of the Ateneum i.e. the Finnish National Gallery include a large histori- 
cal painting portraying Erik XIV (1533-77), King of Sweden 1560-68, resting on Queen Karin Månsdotter's (1550-1612) knee. It was painted in 1864 by Erik Johan Löfgren (1825-1884), who lived in Turku but studied in Stockholm and later spent a lot of time in Düsseldorf and Paris. The professor and Councillor of State, Fredrik Cygnaeus, who was the chairman of the Fine Arts Association of Finland, helped Löfgren in his career and encouraged him to paint monumental paintings depicting events in Finnish history, one of which was the one just mentioned. Cygnaeus was familiar with Erik XIV, since the topic of his dissertation on the history of literature was Erik XIV as a dramatic character.

As was the practise of that time, Löfgren was commissioned in 1862 to paint this portrait by a remarkable donor, the Assistant Judge and Councillor of the State, Herman Hallonblad (1825-1894) from Sortavala (E Finland, now Russia). The commission was part of a concious plan to build up a national art collection, as Hallonblad and his wife Elisabet (1831-1907) intended to bequeathe their works to the Fine Arts Association of Finland. After receiving the commission, Löfgren travelled to Paris in 1862 and finished his painting there.

C. J. Gardberg, the former state antiquarian, in a recent book tells the story of how the body of Karin Månsdotter was removed from the crypt in the Cathedral of Turku and placed in a sarcophagus in the chancel of Kankainen on August 27th 1867. He quotes the lively contemporary description given by Adolf Lindman (1821-1871), a clergyman and a remarkable collector. Gardberg also mentions the tooth, which "fell out" as the body was being removed, and which was pick- ed up by the artist Erik Johan Löfgren. $\mathrm{He}$ 181 ted to the Historical Museum of Turku, founded in $1881 .{ }^{16}$ The tooth became one of the major objects of interest in the exhibition, along with the pistol with which the district police superintendent had shot the famous criminal Kustaa Nummelin, also known as 'Pig-Kyosti', close to Raisio Church in 1836. However, Gardberg emphasises that the tooth was no longer on display but remained in the museum store. The tooth can be found in the main catalogue of the museum, numbered 7674 with the following information: "Karin Månsdotter's tooth. Belonged to the historical collections of Justice Court of Appeal K. A. Weckström. A gift from Justice Court of Appeal K.A.Weckström.” K. A. Weckström (1832-1905) was born in Helsinki and spent the most of his life there working as a lawyer, finally retiring from the post of chief accountant to the National Board of Health. At the end of the 1850s he worked in the Turku Court of Appeal and probably made Lindman's acquaintance at this time. ${ }^{17}$

Kari Suistoranta, who has studied the life of Adolf Lindman, points out that Lindman and Erik Johan Löfgren had been close to the coffin on an earlier occasion, since in August 1862 , accompanied by some others, they broke into the crypt of the Totti in the Cathedral of Turku and opened the coffin of Karin Månsdotter in order to get a realistic idea of the size of the Queen for the portrait! As a result of this visit, after seeing and opening the coffin, which was in a poor condition, Lindman petitioned for an appropriate resting place for the Queen. ${ }^{18}$ In the exhibition texts of Turku Castle it is mentioned that Löfgren had taken the tooth into his possession during this very visit. 
182 It is still unclear whether Löfgren took the tooth in August 1862 or in 1867. Another question that remains unanswered is how the tooth found its way into Weckström's collections. From the perspective of the presentation, these questions are immaterial. The main question is: where does Karin Månsdotter's tooth belong?

\section{A MIRROR IMAGE}

In September 1998, I participated in the first conference of the International Federation of Skiing (PIS) on the history of skiing at Holmenkollen, Oslo, Norway. On the same trip I paid a visit to the maritime museum. To my surprise, among the ships on permanent exhibition I saw a temporary exhibition on "the oldest woman of Norway". The skeleton of a woman had been found in the sea and with the help of radiocarbon measurements the skeleton was dated to the mesolithic Stone Age. The exhibition gave a colourful presentation of the finding of the bones and the research and various analyses that had been carried out and were still in progress. The central exhibit was the skull of the deceased. Since I am not an osteologist or a paleontologist who, instead of mere bones, would be able to see a human being, it did not arouse any great excitement in me. It was only a skull among the many I had seen. I proceeded through the exhibition and suddenly there was a face in front of me that had been given life with the help of a computer program designed to meet the needs of contemporary crime investigation. It was the same head but far removed from the bare skull that I had just seen! What struck me was that the face was familiar even though it was white, hairless and without eyelashes. It could have been any pre-

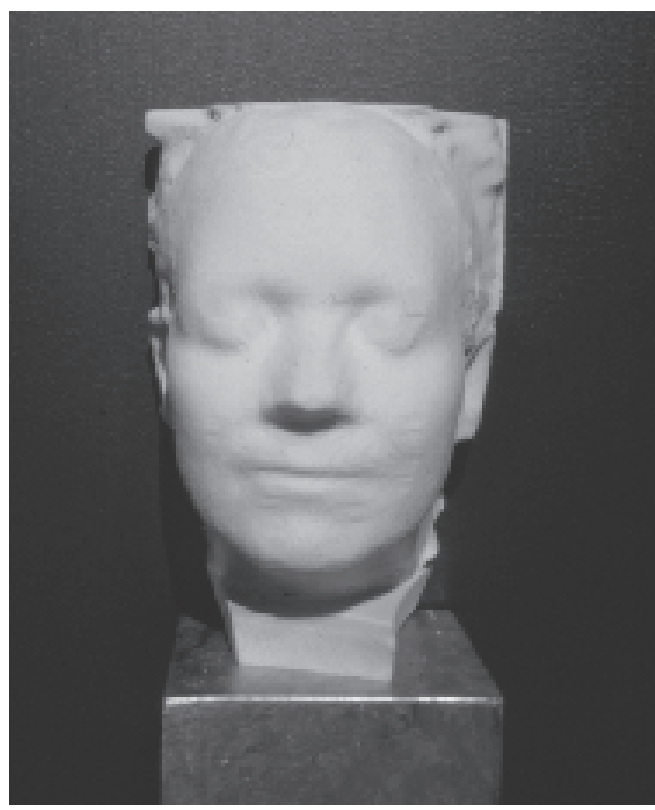

The theme of the exhibition in the Maritime Museum in Oslo in 1998 was "The Oldest Woman from Norway", a skeleton find dating from the mid Stone Age. Apart from the skull, the exhibition included a face that had been reconstructed with the help of a computer program used in crime investigation. Photographed by Janne Vilkuna 1998.

sent day Norwegian woman! It really made an impact on me seeing this "foremother". It was as if I had looked at her reflection in a mirror, and realised that she was just like us.

I believe it is the researcher's task to study people of the past even as physical bodies. Museums and scientific centres can follow the example of Oslo in presenting their results. Part of the museum ideology in former times was presenting all kinds of curiosities, such as deformed animals and human beings or displaying horrific murderers. But these times are gone. It is not the task of museums 
to display the pornography of death. If we want to present the past and its people, we can do it much better by respecting their individuality and showing them the way they were, according to our studies. But we have a long way to go. The following lines appeared in the paper "Archaeology" in the summer of 1998: "The 5,300-year-old frozen remains of 'Ötzi', the Neolithic Iceman, held in Innsbruck since their discovery in the Alps in 1991, have been returned to Italy. They will go on display in a new museum in the city of Bolzano. The clothing, weapons, tools and other equipment will be openly displayed, while the body, in a refrigerated chamber, will be visible through a small bulletproof window". ${ }^{19}$

\section{Notes}

- This paper was presented on February 232001 at a meeting with colleagues from the three Baltic countries in Riga, Latvia, convoked by John Aage Gjestrum.

1. When the code was amended by the 20th General Assembly of ICOM in Barcelona in July 2001 it was translated by the Finnish national committee and adopted in Finland in October 2001.

2. Hannu-Tapani Klami: Museoalan eettisia kysymyksia. Museo 4/90.

3. For example 22.4.2002: http:// www.fcsn.k12.nd.us/Shanley/broanth/ capuchin.htm and http://

Iwww.members.tripod.com/ -Motomom/index3.html

4. For the Church (but fortunately not the body!) see (22.4.2002): http://www.keminmaa.fi/kunta/ matkailu/nahtavyyk/kirkkoml.htm

5. See the homepages of the Institute of Anatomy of Paris (22.4.2002): http:// www.biomedicale.univ-paris5.fr/anat/anatomie/ musee/musee_e.html

6. The exhibition situation today (22.4.2002): http://www.koerperwelten.com/index2.htm

7. The quotation is translated from Finnish: J .R. Aspelin: M.A. Castrenin Muinaistieteellinen perinto. Suomalais-Ugrilaisen Seuran Aikakauskirja (SUSA) XXX.2 1913-1918,25.

8. 22.4.2001: http://www.icom.org/ ethics_rev_engl.html In the 1986 ICOM Code of Professional Ethics, the same chapter but numbered 6.7. and entitled Human Remains and Material of Ritual Significance, was only slightly different: "Where a museum maintains and/or is developing collections of human remains and sacred objects, these should be securely housed and carefully maintained as archival collections in scholarly institutions, and should always be available to qualified researchers and educators, but not to the morbidly curious. Research on such objects and their housing and care must be accomplished in a manner acceptable not only to fellow professionals but also to those of various beliefs, including particular members of the community, ethnic or religious groups concerned. Although it is occasionally necessary to use human remains and other sensitive material in interpretative exhibits, this must be done with tact and with respect for the feelings for human dignity held by all peoples".

9. See Museum News September-October 2000 which theme was NAGPRA.

10. More of the issue: Museum Journal June 1994 in which the theme was Human remains in the UK - A scientific resource and a political problem. See also Gary Edson (ed.): Museum Ethics (Routledge 1997) and Karen D.Vitelli: Archaeological Ethics (Alta Mira Press 1996).

11. These cases are from the Finnish newspaper Helsingin Sanomat 10.5.1992: "Heimopäällikon muumio uhkaa olympiasopua, paljastuskirja 
184 syyttää korruptiosta" and 25.11.1998 Päivi Väänänen: "Täytetty eskimo museossa suututti gröönlantilaiset".

12. I would like to thank researcher Leena Voutilainen at the Criminological Museum for these facts; see also the Finnish newspaper Helsingin Sanomat 1.4.1995 Jarkko Sipilä: "Murhamies Matti Haapoja lasivitriinistä hautaan."

13. Aki Arponen: Inarin hautausmaasaaret. Metsähallituksen luonnonsuojelujulkaisuja A:16 (1993), 12-13. Somewhat surprisingly then in the 1930s Professor Lassila strongly critiziced the race theories of his time and became a spokesman for human rights.

14. Helsingin Sanomat 17.7.1995 Jaakko Tahkolahti: "Saamelaisten pääkallot haudattiin uudelleen Inarissa".

15. The collections of the Finnish National Museum KM 52090:5 and Helsingin Sanomat 19.1.2000 Paavo Tukkimäki: "Henrik-piispan jääinnos pääsee esille."

16. C. J. Gardberg: Tre Katarinor på Åbo slott. Borgå 1986, 162-164.

17. Finlands jurister år 1898 and Finlands jurister år 1909.

18. Kari Suistoranta: Muinaistutkija Adolf Lindman. Turun maakuntamuseo Raportteja 5 (1982),36.

19. (22.4.2002) http://archaeology.org/9805/newsbriefs/iceman.html (Archaeology Volume 51 Number 3 May/June 1998)

Janne Vilkuna is Professor of Museology at the University of Jyväskylä He is also a member of the editorial staff of Nordisk Museologi.

Adr: University of Jyväskylä, Museology, P.O.Box 35, (JT), FIN-40351 Jyväskylä

Fax: +358142601465

E-mail: jvilkuna@campus.jyu.fi 


\title{
About Strategies of Opening and Openness in Lithuanian Museology
}

\author{
Elona Lubyte
}

This is the narrative of a museum employee working during the period of ongoing change that is taking place in our country, Lithuania. After the restoration of independence, a new market economy strategy and the emergence of a private sector can be noted, both related to the new political view. They resulted from the attempt to return to the global context after half a century of Soviet occupation. The museum space is traditionally related to the protection and representation of cultural heritage. In Lithuania, as in the majority of Eastern European countries, museums and their collections are owned by the state. Our country has 93 museums of which 3 are national, 16 supported by the Republic, 56 municipal, 14 departmental and 4 private. A free market is characterised by selfregulatory laws. Exceptions slowly replace previously valid rules. Two private sculpture parks are examples of such exceptions in the slowly recovering Lithuanian cultural scene: the International European Centre Sculpture Museum, 1993, and the Grûtas Park, 1999, featuring disassembled monuments of the Soviet period. The stories of their creation represent two different models for establishing private museums, which, in a general sense, may be characterized as the strategy of opening and openness respectively. The story of the lattery type of establishment gives more insight into the essence of the changes that are taking place.

About "Museum SCIENCE" OR NEW WINDS OF CHANGE

After the first decade of restored independence, when the optimism of the "singing revolution" had calmed down, we experienced quite an inconsistency with regard to changes in museums. We can see that small, new and private structures are more successful at modernising, while old organisations change very slowly. The era of change in our museums started with the separation. In the Soviet period, all objects stored in the museum belonged to the museum fund of the USSR. The activities of museums were coordinated 
186 by the Soviet Ministry of Culture. The current status of museums in Lithuania is based on the Museums Law of 1995, which states that the museum fund of the Republic of Lithuania is a part of the national property of Lithuania. Ministries, urban and regional municipalities, authorities, and private persons may establish museums.

In Soviet times, when the freedom of religion was abolished and churches were closed, branches of state museums were established in the churches to preserve historical collections. This is why, in the 1950s-1960s, the Lithuanian Museum of Fine Arts placed the exhibition of Old Western European and Lithuanian Painting in the classical Cathedral Basilica of Vilnius, the exhibition of Lithuanian folk art in the baroque church of All Saints, and the M. K. Eiurlionis museum of fine arts presented an exhibition of old graphics and applied fine arts in a former baroque monastery in the suburbs of Kaunas, etc. After independence, the act governing the restitution of the rights of the Catholic Church stated that the said church was entitled to independence and the Republic of Lithuania should reimburse it for the losses incurred during the Soviet period and return any of its buildings then in the ownership of the state authorities. The museums which were restored in the wake of radical administrative and organisational changes had to solve complex problems concerning the moving and rearranging of collections and exhibitions. Storage rooms for paintings and sculptures were installed in Vilnius Cathedral Basilica, next to the exhibition.

In Soviet times, as early as at the end of the 1940s Vilnius University was training museum workers and later, the course on museology was taught to students of history at the university and to students of the history and theory of arts at the State Institute of Fine Arts. However an opportunity to become familiar with contemporarty museology in more detail and more systematically came only after the restoration of independence. Neither the museums, nor the nation, expected or were prepared for the changes that came so rapidly. We have experienced the changes as a self-regulating process; not as a series of strategic moves but rather the result of intuitive decisions. Neither the State nor the institutions blown about by the winds of change that accompanied the new ideology have been able to define a united strategy, until now. Public promotion of the cultural decentralisation has given rise to a dense structure of branches of national museums - the Lithuanian Museum of Fine Arts controls the Picture Gallery of Vilnius, Radvilos Palace, the Museum of Applied Fine Arts, the National Fine Arts Gallery, Klaipëda Picture Gallery, Klaipëda Museum of Clocks, Palanga Amber Museum, Suduvite Fine Arts Museum, and P. Gudynas Restoration Centre. M. K. Ciurlionis Museum of Fine Arts has Kaunas Picture Gallery, Mykolas Zilinskas Fine Arts Gallery, the Museum of Ceramics, the Museum of Works and the Collections of A. Zmuidzinavicius, the A. and P. Galauniai Home in Kaunas, A. Rakauskaitë and L. Truikis Memorial Apartment in Kaunas, the M.K.Eiulionis Memorial Museum in Druskininkai, and V. K. Jonynas Small Gallery in Druskininkai. It is obvious that the branches of museums scattered throughout Lithuania and engaged in various kinds of activities would in certain cases operate more rationally as independent subdivisions. Not to mention the maintenance problems of such a number of buildings which frequently increases as a result of the 
organisation of events. State museums are forced to change the nature of their activities drastically, learn how to save, raise additional sources of funding, adapt to the new needs of customers, etc.

Another problem originates in the changes in the provision of the museum services. The collections of the Lithuanian museums are now open to the public in the republic (in the exhibition "Christianity in Lithuanian Art" staged by the Lithuanian Museum of Fine Arts, the public was introduced to the history of ecclesiastical art, 1999-2003) and abroad (the works of M. K. Ėiurlionis were presented in international exhibitions - culminating in a personal exhibition of the artist in the Quai d'Orsay Museum in Paris; and in joint projects of Lithuanian and Polish museum workers in 2000 , etc.). New expositions and exhibitions are followed by targeted educational programmes. Unfortunately, the state museums have so far failed to realize that this process requires not only a well-developed administrative staff and professional keepers of collections, but also organisers and curators of the exhibitions. The organisation of artistic events is a complex and time-consuming process in which, apart from the directors and administrators, the staff implementing the idea plays a very important role. This role and their competence regarding the national cultural policy, is now considered as especially important, although still not clearly defined in the funding of projects. In my 14 years of employment with the Lithuanian Museum of Fine Arts and having organised 10 exhibitions at my central institution and outside I have learned that the approach of the state museums to the organisation of events is changing particularly slowly.

These remarks are not an attempt to hide or solve all the problems facing the Lithuani187 an museums in a time of change. They do, however, serve as an introduction to the following stories about the intentions of two personalities representing different generations and different philosophies in their exploration of the new power of private initiative in the museum field.

\section{About the strategy of opening, OR THE ATTRACTION OF THE NEW CENTRE OF EUROPE}

The strategy of opening reflects an approach which attempts to open up to the global development processes, to return and rejoin the international scene and become an equal part of it. Eight years have passed since the first international sculpture symposium, which was held in 1993 near the private house of Gintaras Karosas. He was a student of sculpture at the Vilnius Academy of Fine Arts, with a house, situated in an old suburban woodland abounding in springs, $19 \mathrm{~km}$ from the capital. At the moment, this outdoor Museum of Sculptures of the Centre of Europe (area - 55 hectares) has 66 sculptures. Annually it receives about 50,000 visitors. What is the story behind the museum, the first private museum in Lithuania, established by a young student, which in the beginning raised many doubts but which has exceeded the most optimistic forecasts made by its advocates in the course of its being established? The idea of the museum has its roots in the first public political meetings and actions of the "singing revolution" (the Baltic Road of 1989, when during the 50th anniversary of the Ribbentrop-Molotov Pact the citizens of the annexed Baltic States held hands and demonstrated their determination to restore indepen- 
188 dence to the whole world by means of their living chain along the Vilnius - Tallinn Road). At that time we cherished romantic hopes that all our ideas would come true and we could not imagine the efforts needed to achieve our goals. In such an environment the young sculptor had the idea that he wanted "to give a meaning to a geographical centre of the European continent by means of the language of art". In 1898, the fellows of the French National Geographic Institute located the centre close to the Lithuanian capital. G. Karosas started to implement his idea with the creation of the sculptural sign for the new centre of Europe, which later came to be the logo of the museum. In 1991, this sculpture was erected at the location of the new centre of Europe on a plot of cultivated land. The young artist started to look for a place in the vicinity which would be suitable for the location of the new sculpture park. The suburban environment, abounding in hills and forests, stret-

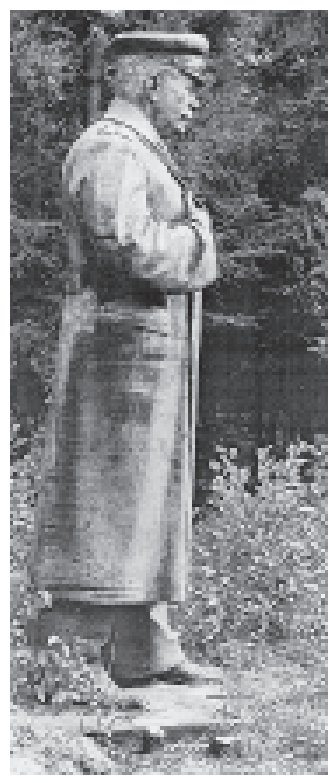

ching close to the new centre of Europe is reminiscent of the Swiss Alps. Lithuania is a country of forests. Nature with its forests have become indispensable parts of the environment in the consciousness of most of us. The ideas of the young artist were not born in a vacuum. In the 1970 s,

Grûtas park. The monument to Stalin. symposia on granite sculptures were organised in the seaside town of Klaipëda. In the course of time, mainly because of the remote situation and the ambitions of the young artists, they became a place in which to bring to realisation new and modern concepts. In the 1980s the network of sculpture symposia grew (with a metal symposium in Alytus and a concrete symposium in Aukötieji Paneriai, Vilnius), and the first sculpture exhibitions in public spaces emerged, which were replaced by new conceptual art projects in the 1990s. At the beginning of the independence movement, the sculpture garden in Jeruzalë, Vilnius, legalised its activities. It united the artists who had settled in the suburbs of Vilnius and, in the Soviet times, had contributed to the dissemination of the modernisation processes in our environment. Sculptor Vladas Vildziûnas, who was one of the founders of this movement, had been a lecturer when the young artist studied at the Vilnius Academy of Fine Arts.

The young artist found an attractive space near the new centre of Europe and, with the help of his parents, built a house, which has now become the home of international symposia and the office building of the first private museum in Lithuania. At the same time he cleared the surrounding forest and excavated ponds in areas around the springs. The reflections of the increasing number of sculptures on the sparkling surface of the water in these ponds have become an important element of the new museum. To implement his idea, the young artist registered a private company Sculpture Museum of the Centre of Euro$p e$ and started looking for sponsors for the first sculpture symposium. In contrast to the state museums which were regularly funded from the national budget, he had to raise sub- 
sidies by himself. The first international symposium of the Museum of the Centre of Europe was sponsored by Unesco, the G. Soros Open Society Fund Lithuania, private Lithuanian companies, and individuals. Ten sculptors from Greece, Lithuania, the USA, Hungary, and Finland participated in the symposium. Some of them were college students and their organisations subsidised their journey and stay in Lithuania. After a successful first event, with the help of foreign funds and organisations, Karosas familiarised himself with the activities of private sculpture parks in the USA and Japan. These ideas were especially useful in the formulation and adoption of a strategy for a future museum. Its essence was the evolvement of an alternative to the welldeveloped collective events organised during the first years of the museum and thus it focused on the implementation of strong and ambitious projects. This programme is realised in two ways: by attracting "names" and by the organising of meetings for young artists from Eastern and Central Europe.

In 1996, the first ambitious project was realised in the Museum of the Centre of Europe. The work of Dennis Oppenheim "Armchair-pool" (470 x 523 x $570 \mathrm{~cm})$ was produced, exactly according to the model, in a factory under the supervision of an assistant. The artist was satisfied with the result of the cooperation and agreed that another of his works should be built in the park. Thus, in 1997-1998. a paradoxical, grotesque work was created, "Drinking Structure with Kidney-Shaped Pool" (1000 x 900 x $550 \mathrm{~cm})$, inside which a spectator can experience a variety of sensations because of the uncomfortable space. These works were the first representations of live pop-art classics, not only in Lithuania but also in Central and Eastern
Europe. At the same time, a minimalist con189 crete "Double-Negative Pyramid" (560 x $1200 \times 600 \mathrm{~cm}$ ) by Sol LeWitt was created following the directions of the artist. Eventually, the initial interest in the park with great artists sending their assistants to carry out their ideas, was superseded by an active and creative process of cooperation. This cooperation with the famous Polish sculptor Magdalena Abukanoviè was especially important for the young artist. Abukanoviè first visited the park in 1997 when she was looking for a place to exhibit her small sculptures, but she was captivated by the environment and decided to create what has become one of her major compositions - an assembly of twenty-two abstract concrete segments and natural stone pebbles occupying over two thousand square metres, entitled "Space of Unrecognised Growth", 1997-1998. The acquaintanceship and cooperation with this artist taught G. Karosas a new lesson allowing him not only to experience his dream coming true but also to get feedback from that experience. This is how a whole network of meaningful cooperation developed. Between 1999 and 2001, an ambitious steel project by a young Czech sculptor, Aleö Vesey, "The Idea of Sculpture is a Sculpture"

Grûtas park. The monument to Lenin.

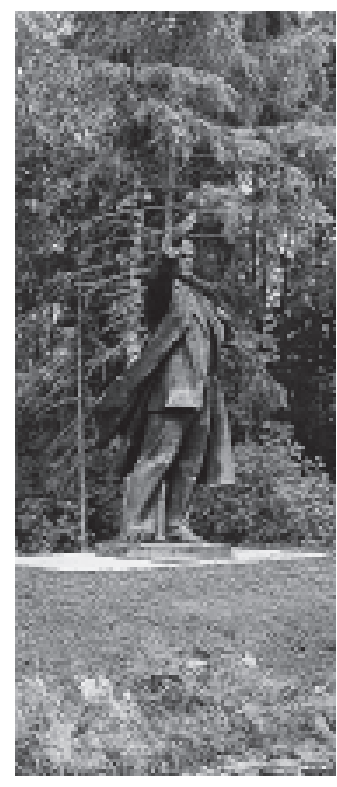


$190 \quad(880 \times 792 \times 793 \mathrm{~cm})$, was erected in the park. An innovative ecological composition by a young artist, Mara Adamitz Scurpe, from the USA, "Suspicious Science", with active solar batteries represented new technology. Perceiving the territory of the museum park as his creative space, Karosas together with the invited artists, created his own sculptures ("Monument of the Centre of Europe, 1997, "LNK Infotree", 1998, "For Your Convenience", 1999), looked after the forest and designed the aggregate image of the Centre of Europe.

The extent of the park is increasing along with the number of ponds, the specially trimmed trees are thriving, an asphalt road has replaced the simple gravel path, and a parking area has been built. The museum park has become a favourite visiting and recreation place for young people, gardeners working nearby, and guests of the city, with approximately 50,000 visitors annually. And the young artist is improving not only his artistic skills but also his administrative, organisational and marketing skills. It is not enough simply to interest an artist in the possibility of realising his or her idea in the new postCommunist centre of Europe, financial support for these projects is necessary. The cost of the largest objects is estimated at LTL 200,000-300,000 (USD 50,000-75,000). State support for Karosa's projects amounts only to about five percent of the value of the works. The remaining funds are raised from tickets, local and international sponsors on six levels, from major donors to families and private individuals.

Today the young founder of the first private museum feels he is a citizen of the world as he communicates with artists from all over the globe, makes independent decisions not only about what or how, but also about how the existing collection of the museum is to be enlarged. And the diverse and ambitious international collection of sculptures exhibited for visitors to the museum is becoming an opening, a "bridge between different cultures", or to be more exact, between 22 countries whose artists created their works in the new Centre of Europe.

\section{About the strategy of openness, OR A NEW APPROACH TO THE FUTURE OF SOVIET IDOLS}

The strategy of openness is associated with what is new, fearless and permissive, i.e. a free and democratic attitude towards the historical past. Since ancient times new monuments were built and old ones destroyed when one political system replaced another. Ancient Rome had a law "Demantio memori" (Curse of the past) which said that all statues, reliefs or inscriptions created to glorify a condemned person must be destroyed so that the name and appearance of the condemned would be erased from the memory of future generations.

After the restoration of independence, the signs of the old system are being changed. In 1989-1993, in Lithuania 42 monumental Soviet sculptures were dismounted. In 1998, an open competition on the "establishment of the exposition of Soviet monumental sculptures" was announced and was won by a private organisation, to which the dismounted pieces were handed over. Since 2000, they have been exhibited in the Grûtas Park of the Museum of Soviet sculptures, which was visited by nearly 50,000 people in the first year.

It is worth noting that this decision was very controversial in Lithuania. There were passionate opponents and advocates and the argu- 
ments of both sides were willingly presented in the free media. The experiences and losses of the past aroused particularly strong feelings. During the black years of occupation from 1940-1956, Lithuania lost 1 million of its population - 240,000 were killed by Nazis, and 360,000 by the Soviets, killed in the resistance movement, an additional 400,000 people were deported and forced to leave the country. Naturally the public attitude towards these painful issues is not homogeneous: some wish to erase from their memory all the names and symbols of this period while others believe that the overthrown idols will help us never to forget our painful history. Everyone is right in their own way. Our neighbours in Latvia melted down the Soviet monuments and moulded bells, which were given to the victims of the repression, while the Hungarians created a public exhibition of the sculptures. Reprints from publications, letters, speeches, and resolutions compiled on a 200metre-long stand in the vicinity of the park became not only the history of the realisation of the idea but also a testimony to the variety of attitudes in our society.

In contrast to the hero of the previous story, this museum-builder is an experienced, mature, decisive businessman willing to take a risk. In the Soviet period, Jonas Malinauskas was the chairman of a prosperous collective farm. His career started on a pheasant farm, established in 1967, and favoured by visits from the Soviet leaders. After the restoration of independence, this former leader initiated some new activities. In a recreational area in Dzûkija, which abounds in forests he established a private wood and mushrooms processing company. Its current turnover totals LTL 12 million (USD 3 million). The company employs 200 people on a regular basis and up to 500 in peak seasons. J. Malinauskas' fresh and canned mushrooms are exported to Western Europe, the USA and Israel. It is a family business. His income is invested in the development of the agro-tourism sector, which is new in our country. Next to the Druskininkai resort, famous in the Soviet era but dying today, is a recreation site with tennis courts and a stud farm is being built on repurchased land near the shore of a picturesque lake which is rich in fish. Making complex plans for the development of the recreational business J. Malinauskas had the idea of creating a new space for a cultural attraction. This is how 200 hectares of forest marsh (covered with a soil layer of $0.5-2.5$ metres) came to be drained near his private house and facilities erected near the shores of the lake. This former kingdom of marshes and mosquitoes symbolically shelters the idols of the old ideological system. The exhibition in Grûtas Park was put together over two years. The estimated cost of the project - LTL 4 million (USD 1 million) - was met from the capital of a successful private businessman.

In discussing the thematic composition of the park it is worth mentioning that the new owner pursued a rational policy in implementing his idea. Ignoring all heated public discussion, he invited the creators of the former monuments to help him and they willingly participated in the relocation of their works. Meanwhile he started to include an introductory space adding some sort of interpretative material. As you enter the exhibition in the park, there is an information centre which has a collection of Soviet attributes, works of fine art, uniforms, diplomas, the writings of the Marxism-Leninism apologists, and the film chronicle "Soviet Lithuania". Today the exhibits, which for the majority are somewhat ex- 
192 otic, are complemented by recent data from historical studies, some statistical materials about the exile, the partisan resistance movements and collectivisation. Research fellows from the state "Museum of Genocide Centre" helped to prepare historical comments for the museum. It was important for the founder that the visitor would have an accurate commentary on historic events. After you leave the historical centre, you enter an island surrounded by a channel and move along a wooden path surrounding the island which is reminiscent of the rails of the railway taking the deported people into exile. The dismounted monuments, with their comments, are located on both sides at equal intervals Lenin, Stalin, Dzerzinski, Putna, etc. Passing by these stone and bronze statutes is uncomfortable for those who still fear the past. The impression of the past regime is strengthened by the sound of Soviet songs, imitations of the barracks in the exile camps and partisan dug-outs deep in the forest as a background to the monuments. I, who remember the sunset of this system, was disturbed by the literary references. The part of the exhibition showing the portraits of those who opposed of the idea of the current park, carved by folk artists, feels especially out of context. It looks as if the strategy of the founder of the park is to condemn both old and modern opponents. But modern museology recognizes the advantages of the Disneyland-type exposition. In the market environment, demand governs supply. My students, for whom socialism is only a historical concept, liked this kind of exposition. They stated that it was an attractive and instructive way to learn history.

The founder of the park understood the new consumer-orientated needs of the visitors pretty well. As an efficient and caring owner he reacts promptly to their requirement. A restaurant has been established near the park offering some 'forest food' disheswith mushrooms. A separate menu for lovers of exotic things offers some Soviet cuisine - a drink of Russian vodka from a glass with the edge dipped in salt with a piece of rye bread and pickles, herring with pickled onions and potatoes from an aluminium dish or red cranberry kisel. The smallest visitors of the park have not been forgotten either. They can enjoy a large playground in a meadow near a pine forest, which is also often favoured by their parents. A nearby enclosure with some animals appeared after one young visitor remarked that his strongest memory of the park was of a white hen in a cage.

The owner of the park has started talking about his latest idea which is to build a gallery of Soviet art, exhibiting the official and representative works of that time, such as the ideological pieces made of stained glass, since the problem of dismounting and preserving them is worrying their still living creators. Our relationship with the history is individual and it is obvious that the concept of Grûtas Park has and will continue to have its advocates and opponents. Nevertheless, it is an idea realised on the initiative of a private person, i.e. his attitude is just one of a wide variety of options in a free and democratic environment.

Elona Lubyte (born in 1964), critic of fine arts, curator of exhibitions, 1982-1987 studied art criticism at Vilnius Academy of Fine Arts, 1995-2000 doctoral studies at Vilnius Gediminas Technical University, in 2000 granted the degree of Doctor of Philosophy in social sciences (management). Since 1987 working at the Lithuanian Museum of Fine Arts. Since 1991 member of the Lithuanian AICA (Association for International Art Criticism), President of the section since 1998. 


\title{
SOURCES OF THE National Museum of Lithuania
}

\author{
Zygintas Bucys
}

"Not all yet understand the true meaning of the Museum, thinking that it is something like Valhala, where morality and genius must be exalted. Not all yet understand that Archaology, trying to avoid empty inducements, today's passions, is not obliged to flatter a nation's pride. By collecting monuments of all that was alive and interesting in the past, history is given the right to evaluate, praise or condemn. In the faces of ancestors it is not looking for beauty, but likeness". 'The first museum in Lithuania - the Vilnius Museum of Antiquities - was established almost a hundred and fifty years ago (1855) according to this statement of belief by of one of the most famous researchers of Lithuanian culture in mid-19th century, Adam Kirkor.

Despite the difficult circumstances during the occupation by Czarist Russia, the museum was established as a national museum, and throughout its history it had to endure various calamities: the removal of a major part of its collections to Russia, the abolition of the museum and the dissipation of its collections. Only in 1952 through the efforts of the famous historian of Lithuanian culture, Vincas Zilenas, was the structure of the Museum of Antiquities recreated on the basis of a part of the original collection and of collections from the scientific communities of Vilinus. This restored collection reflected the history of the Lithuanian state and the national culture. In this way the work begun by the mid-19th century intelligentsia was continued. In 1992 the museum was named the National Museum of Lithuania.

In 1855 when the Museum of Antiquities was established the independent Lithuanian state was already only an episode from the past inscribed in the cultural memory. However it had not been completely deleted, rather it was being continuously restored in preparation for the realisation of the historical fact in a political life that was at least minimally independent. The exposition of the museum, which contributed to keep historical consciousness and cultural identity alive, tried to restore Lithuanian patriotism. The idea of establishing a museum had matured long before it became a fact, therefore I will look at the beginning of the historical collections in Lit- 
194 huania and the growth of an awareness of antiquities as representing historical and cultural values.

\section{MADNESS FOR THINGS}

"This is really a madness for things" - said Konstanty Tyszkiewicz, a witness of these days and an active participant, describing the outburst of antiquities collecting in the first half of 19th century. ${ }^{2}$ This was the reaction of a scientist and culture researcher to the random, chaotic collecting of objects, not defined by scientific categories or systems. Generally, it was the attitude to a certain section of society which did not value cultural heritage and did not apprehend its meaning.

A hitherto inexperienced passion for collecting things pierced the hearts of various layers within society: beginning with the duke and count but also affecting the small provincial nobleman. Of course, this desire to collect did not appear overnight; collecting was known even earlier. However, if in the 18th century only aristocrats like Radziwill, Sapieha, Oginski, Chreptowicz, Tyzenhauz and other dignitaries could take pride in their collections, in the 19th century collecting became a universal phenomenon. Often a private collection reflected fashion, pride or some sort of self-establishment in society; and for the majority the contents had no importance: antiquities, archæological finds, numismatics or art works - all were equally desirable. Everything depended on the nobleman himself: his taste, inclination and of course his fortune. It was rare for anyone to engage in purposeful, systematic collecting. There were all kind of things in the private collections: family relics, objects from exotic countries, local rarities, and the collection it- self balanced on the edge of temporality, amalgamating with others, passing from hand to hand or disappearing from the cultural horizon just at the time it had acquired some contours and definition.

The wave of collecting things that arose in the first half of the 19th century was figuratively described by A.Kirkor in a letter to Józef Ignacy Kraszewski, where he mentions a silver statuette, owned by "some small nobleman Czechowicz, an ignorant person, but very fond of antique things, who kept it under the key and didn't show it even to his wife. This strange man dug into many barrows. Poor man, but ready to risk everything in order to get antiquities. People say, that he has coffers full of them."

$\mathrm{K}$. Tyszkiewicz met many local collectors on his scientific journeys on the Neris river. P.Ordynec - collector of antiquities and old legends in Milcia. ${ }^{4}$ Priest Debinski who had a few finds he had himself dug out of surrounding barrows. ${ }^{5}$ In Kernavele manor he saw an art collection comprising mostly of the works of Kanuty Rusiecki. The owner of this collection was "a real brother of our painter" ${ }^{6}$ In Paparciai in the company of the painter Antoni Zaleski he visited a "beautiful gallery of old paintings from the Italian school"belonging to the painter's uncle and he was surprised by his "very rich collection of old Saxonian porcelain unique in Lithuania." In Mikaliskis Tyszkiewicz met with Doctor Minkowski, who " had a small collection of rarities - a few items of old Saxonian porcelain, especially interesting was a cup with top. It had a bust of Stanislaw August in the form of medallion painted inside the cup, and written around it was: "Stanislaus Augustus Rex". On the bottom of the plate was an open book and the symbol of righteousness with lifted finger, laurel crown and all attributes of the memorable event of 1791 . 
Today this cup is quite a rare antiquity, signifying the country's majestic act. (...) Minkowski selected a corresponding silver spoon for this cup, which I saw for the first time here. There was an embossed portrait of Duke Jozef Poniatowski." 8

The scope of archeological research and collecting in Lithuania is also described in the writings and correspondence of the historian Teodor Narbutt, where we can find out about the collectors of that time: Józef Pomarnacki, Karol Kozakowski, Adam Zagiello, Jerzy Plater, Franciszek Wilczynski, Oskierka, Marcin Ciepliniski, Józef Jaroszewicz. ${ }^{9}$ Narbutt himself had quite a big collection of Lithuanian antiquities. L.Jucevicius in his work "Mokyti zemaiciai" (Educated Samogitians) also mentioned Michal Chlewinski, Jan Chryzostom Gintyllo, Leopold and his son Albert Gorski, Dionizas Poska, Jan Prekier, Antony Rönne, Leon Uwojn and Edward Wolmer, as " having rather big libraries", " rooms of numismatics", "collecting antiquities" that were "dedicated to Lithuanian antiquity" 10

These were not all the collectors in Lithuania at that time, since Narbutt and Jucevicius first mentioned those collections that were important for their own research and scientific interests. There were many such amateur antique collectors, such as the above mentioned Czechowicz - who collected in secret and kept it quiet. Others sought evidence of their noble origin by collecting family relics, and adding various local rarities. This was not interesting for historians of the time.

It has to be remembered that the habit of collecting local antiquities as representatives of cultural heritage was not yet properly established or clearly defined. As inventory books from the end of the 18th and the beginning of the19th centuries show, there was a cabi-

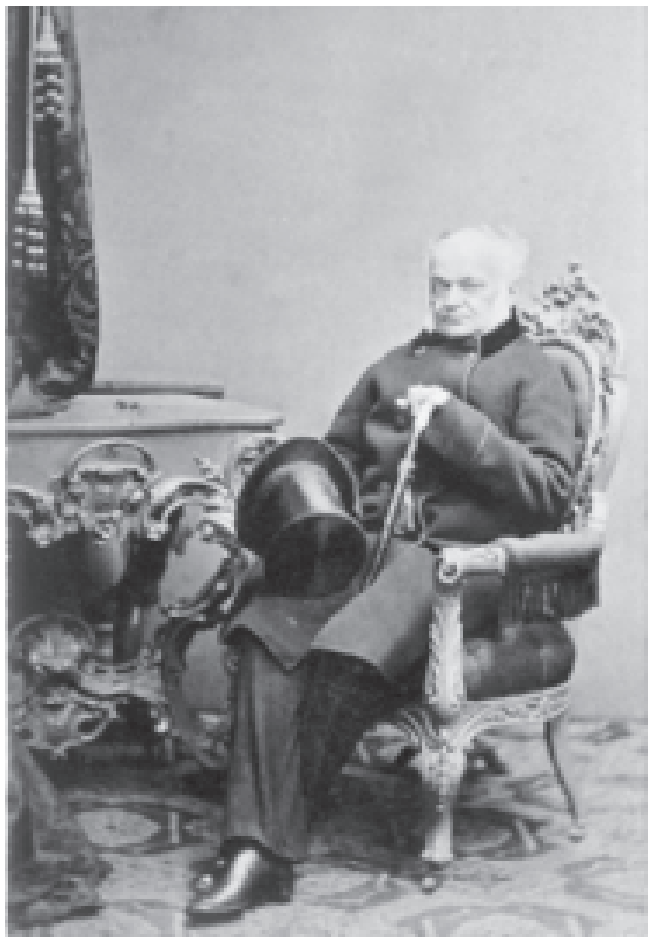

Count Eustachy Tyszkiewicz (1814-1873), archaologist, collector, researcher in Lithuanian history and culture. He was the founder of the first Lithuanian museum, The Museum of Antiquities in Vilnius, which opened in 1856.

net or library, expensive crockery, porcelain, furniture, a splendid collection of arms, and art work in the manors of most noblemen. ${ }^{11}$ But in many cases the fact that these things were not collected from the neighbourhood, that they were used for everyday purposes and were not understood as being of cultural value prevents us from calling them collections. Even among collectors of that time antiquities were sometimes apprehended in this way. "Priest Grosmani, one of the antique collectors of that time, had a few stone hammers in his 
Zygintas Bucys

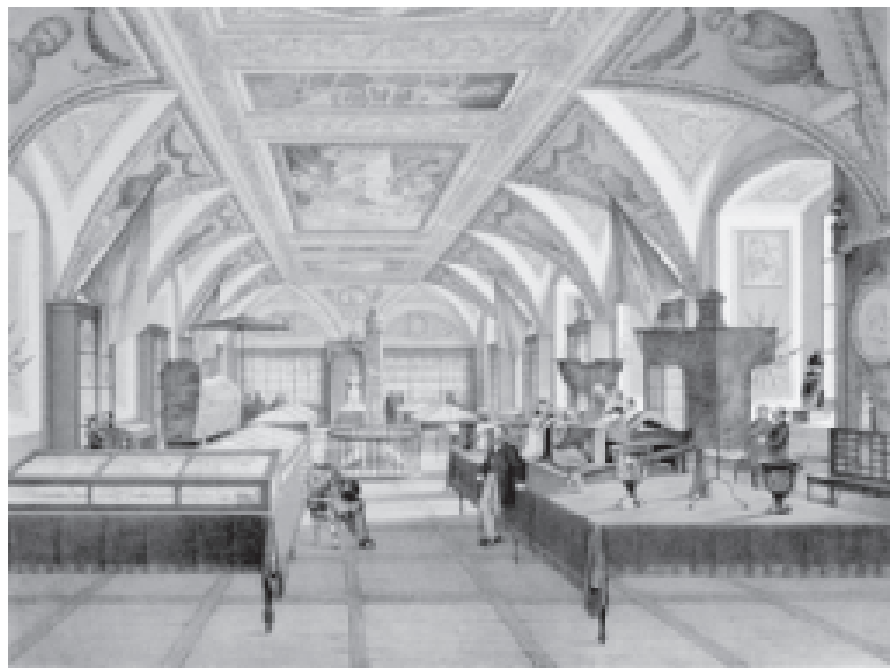

The Museum of Antiquities. An exhibition in the P.Smuglevièius Hall of the University. In the period 1860-1865.

scientific collection which consisted of various utensils arrayed in tasteful disorder, and laughing with satisfaction (which showed his poor worldview) he demonstrated to everyone, how he cleverly found a purpose for this thing: he put candles into its hole and it served as candleholder." 12

At the same time there was a diametrically opposite appreciation of things - as being of cultural value, as testimonies of various historical periods. Narbutt demonstrated such an understanding: to him a wooden stick with unreadable writings was an "antique of antiques of ancient Lithuanians" - "sceptre of Gediminas" ${ }^{13}$ The absence of collecting traditions, the undefined concept of collections and the newly born inclusion of local antiques into the sphere of cultural expression gave rise to such a dual attitude toward them. What was of value to one person, could be completely insignificant to another.
Peasants had a much more pragmatic view of local antiques. "1811 three brass statuettes were found on the bottom of a drained lake in the Druja area. (...) Villagers sold them to Jews in Druja." "In Svëksna in the garden of the parsonage a servant took the treasure which he found while replanting roses - it is supposed to have been a few pounds of golden coins. This man went abroad and the valuable finds disappeared." Only at the end of 19th century do we meet the first collector among the peasants. ${ }^{16}$

The clearest and most important feature of collecting in the first half of 19th century was the nobility's turning toward the past culture of their own country, trying to understand it with the help of local antiquities. Classical cosmopolitan nature cabinets of numismatics, natural science, art and antiques which dominated in 18th century were updated with new energy. Local antiques were 
added as reminders not only of the times of Stanislaw August or Napoleon, but also of gods and relics of pagan Lithuania or as witnesses of Lithuanian battles with crusaders: arrows, swords, armour.

Archæological finds that were reminders of Lithuania's past which had not hitherto been considered objects worth collecting now found their place in the collections of the aristocracy. In the art gallery of Tyzenhauz Pastoviai manor apart from 16th-17th century art works by Italian, Dutch, French, Spanish and other artists one could also see Lithuanian antiquities found in burial mounds in the Pastoviai area: bracelets, beads etc. ${ }^{17}$ There was a "glass ball with tears inside found in a Lithuanian grave; the brass statuette of a man, some god a few inches tall' in a famous collection of arms and art works belonging to Count Józef Kossakowski. ${ }^{18}$ The brothers Counts Eustachy and Konstanty Tyszkiewicz, and Count Jerzy Plater were widely known for their Lithuanian collections and archæological research. Those of the Lithuanian aristocracy who were not so interested in science were not however indifferent to local antiquities. "Duke Cezary Giedroyc, (...) said that in his domain on a high mountain in the woods there is a gully about which many legends exist. They say that there were old graves there, and that one can dig and find interesting things, especially stone beads and big pieces of amber. Duke Giedroyc promised to excavate a few such old graves and send me the finds together with a topographical map of the mountain, with written legends." 19

The modern Lithuanian intelligentsia stimulated by patriotic feelings entered the search for local antiquities. Karol Kozakowski who excavated the Obeliai burial mound near Ukmerge called it a "Lithuanian Pompeii ${ }^{20}$, and generously shared his findings with Adam Zagiello, Siesicki and Franciszek asts for antiquities did not keep information to themselves, but actively communicated and knew about each others' collections through personal correspondence, newspapers or through visiting each other. Periodicals of that time had plenty of news about finds, collections, and as there was no clear understanding of the purpose of some objects the periodicals attempted to explain them scientifically. T.Narbutt, A.Kirkor and E.Tyszkiewicz were especially renowned as trustworthy experts.

Thus before the Vilnius Museum of Antiquities was established, we can discern two ways of gathering collections. Firstly the collecting of some universal, heterogeneous but distinctive things predominated in the Lithuanian society of that time. It was motivated by a desire to express one's own world view, a realization of one's domestic heritage through collecting antiquities, and considering their application in shaping reality. This view dictated the selection of antiques - rare, interesting objects or those which were somehow meaningful or beautiful to the collector himself. On the other hand some of the Lithuanian intelligentsia formed a new generation of collectors, who pursued a conscientious search for a Lithuanian cultural heritage, from prehistorical stone axes to the events of 1812 , which they sought to purposefully collect and systematize, propagate and keep as a heritage for future generations. Their interest in monuments that reflected Lithuanian history was also stimulated by a "love for the nation", not just scientific curiosity. The museum was the institution that could preserve these monuments and inspire society to undetake this cultural-patriotic action. 
In many European countries the first museums were established by giving form and structure to already existing private collections: defining their social status, legalizing their public role, outlining further collecting principles. These matters were now significant not to a single collector but to the whole of society. The Vilnius Museum of Antiquities was no exception, it was founded on the collections of Count E. Tyszkiewicz. The possibility to create a museum in Lithuania already existed at the beginning of the 19th century. However it remained only a possibility. In 1775 the "Musaeum Polonicum" project (similar to the British Museum in its structure) was discussed in the Warsaw Parliament, but it never came to fruition. ${ }^{21} \mathrm{Had}$ there been a positive resolution to this project and knowing the ambitions of the Lithuanian nobility it is reasonable to assume that its existence would have received attention in Lithuania. Moreover, the Chreptowicz Szczorse manor collection was known and visited by the intelligentsia and scientists and was called the "Lithuanian Pulawy". ${ }^{22}$ It was considered to be equivalent to the most famous collection at that time, the Czartoryski Pulawy collection, founded in accordance with the motto "the past for the future". ${ }^{23}$

Vilnius University had several realistic chances to establish the museum, since it was the only institution in Lithuania at that time which organized cultural life and it had a variety of collection cabinets. In 1803 its numismatics cabinet consisted of 268 medals and 195 coins. $^{24}$ In 1814 the university acquired Symonowicz' mineralogy cabinet consisting of 20,000 items, one of the largest in Europe. ${ }^{25}$ The university lecturers J.E.Gilibert,

G.Forster and the noblemen M.Oginski, J.Wichert, M.Walicki granted it their nature collections. ${ }^{26}$ There were more such gifts. They were mostly motivated by a trust of the university not only as educational institution, but as an institution able to preserve a cultural heritage for future generations. On the basis of these collections the university had established cabinets of numismatics, mineralogy, zoology. It also kept local archæological finds which had not yet formed a separate collection cabinet.

K.Tyszkiewicz mentioned, that "in its collections the University has not only highly appreciated Roman and similar monuments, but it also had in its storage silver diadems, bronze necklaces, found in graves and memorials of the era before the birth of Christ. There were a few sacrificial stone hammers. However nobody would even glance at these things" ${ }^{27}$ A.Kirkor also had a similar opinion: "university professors looked at the finds with such contempt that they did not even find a proper place to keep them and they were stored in the loft where they were found in 1855". ${ }^{28}$ Yet, if antiquities were found in the university, they must have been interesting to somebody, otherwise how would have they got there? Most probably professors and researchers at the beginning of the 19th century had a different view of local antiquities. Jan Gwalbert Rudomina read a report about antiquities at the university meeting in 1817 and presented the remains of antique arms found in the Labunava manor, which testifies to the interest in local monuments. ${ }^{29}$

No doubt these University collections were still very far from constituting a proper museum. Attached to different faculties the cabinets served educational needs but were not considered to be elements of cultural herita- 


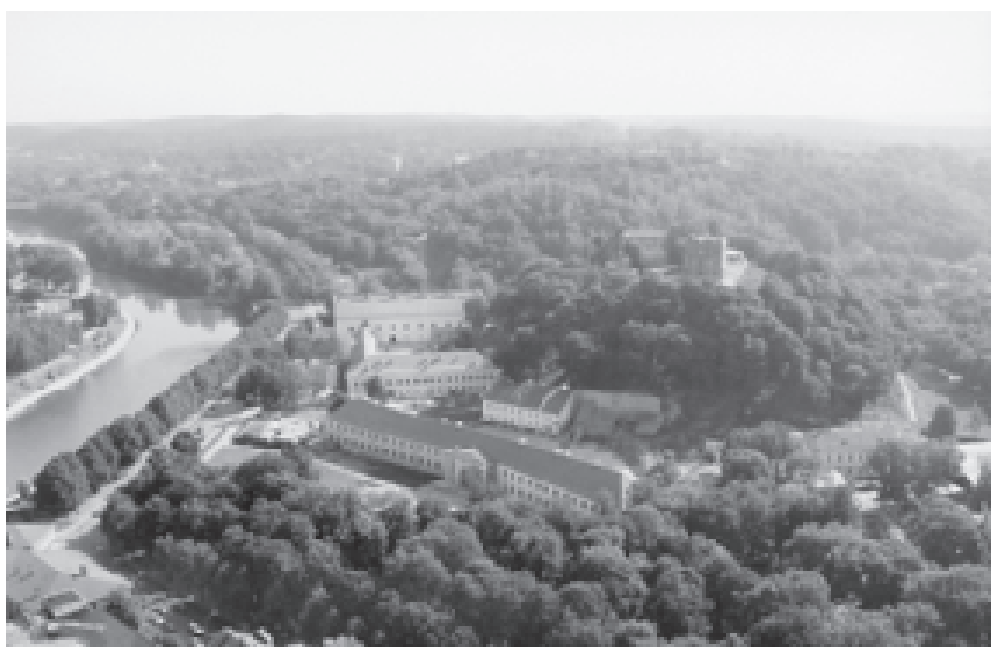

A bird's-eye view of the National Museum of Lithuania, Vilnius.

ge. Unfavorable historical circumstances (the university was closed in 1832 by the Czarist Russia administration) precluded these collections from becoming a museum.

It was Count Eustachy Tyszkiewicz (18141873) who initiated the founding of the museum. He was a cultural historian, a national patriot and a man of wide scientific interests. According to his own words, as he was spending his summer holidays of 1837 in his native land, and being interested in local barrows, he conducted excavations and published the results in the press. The historian Teodor Narbutt replied to his article and mentioned that the newly found antiquities could form the beginnings of a Lithuanian museum. This idea inspired by T.Narbutt remained with Tyszkiewicz. In 1846 at his home in Vilnius he opened an antique cabinet there for anybody who wanted to see it. A private and unofficial museum however could not embrace the wide scientific and cultural aspirations of Tyszkiewicz and like-minded people, so in 1848 he addressed the Vilnius governor-general with a proposal to establish a Provincial Museum in Vilnius. However this project was delayed by the Czarist administration and only a few years later, on May 11, 1855 did the Czar finally sign the order to establish the Vilnius Board of Archæology and the Museum of Antiquities. Understandably, under the circumstances it was impossible to call this museum the "Lithuanian Museum" as E.Tyszkiewicz wanted.

The museum opened on April 29, 1856 in the premises of the closed Vilnius University. It was the first public museum in the history of Lithuania, as it was open at set hours to everyone who was interested. The museum, despite of Czarist administrative control, was 
200 in fact public, like the majority of European museums at the time. The basis of its exhibitions was antiquities from E. Tyszkiewicz' private collection which had been granted to the museum. Libraries, scripts, documents from closed Catholic monasteries and churches, together with the remnants of the Vilnius University cabinets, were included. The further growth of the museum collections was based on gifts from private individuals and organizations. The most significant exhibits were given to the museum by noblemen, landowner families with old historical and cultural traditions. In this way the museum acquired an ornithological collection of more than 1000 items collected by the father of Count R.Tyzenhauz; part of a famous collection of arms donated by Count F.Kossakowski; a collection of Lithuanian antiquities gathered by A.Kirkor; single gifts from Dukes Oginski and Radziwill and Counts Plater, Tyszkiewicz and other noblemen. These exhibits were therefore also significant as sources of Lithuanian history. The passing of big collections from landowners to the museum did not take place on a large scale. Most of them kept their splendid private collections, offering the museum only one or a few exhibits. It is possible that things which were related more to Lithuanian history than to the private life of individual noble families were selected for the museum. At least such selection criteria were expressed by the museum organizer, E.Tyszkiewicz, himself. ${ }^{30}$

The collections grew rapidly thanks to the members of the board and the local intelligentsia who actively participated in the search for objects not only in the territory of former Grand Duchy of Lithuania but also abroad: in Prague, Krakow and other places. Efforts were made, on the initiative of E.Tyszkiewicz, to return to Lithuania valuable cultural objects taken to Russia. For this purpose the board undertook a wide search and printed the results. In 1859 A.Kirkor visited libraries and museums in St.Petersburg making notes on Lithuanian antiquities, at the same time another member of the board - D.Soncov worked in Moscow on the same mission. ${ }^{31}$ E.Tyszkiewicz himself visited high-ranking officials in the Czarist administration for this reason. As a result quite a few copies of historical documents were made, some of the duplicates in the Nieswiez library ${ }^{32}$ were returned, in Kiev University copies were made of Runic calendars that belonged to Vilnius University. ${ }^{33}$ But the major part of the exhibits came to the museum from the territory of the former Grand Duchy of Lithuania, from the Vilnius, Kaunas, Grodno and Minsk provinces of that time.

Apart from the board members themselves, ordinary citizens, state officials and students actively joined in collecting. Perhaps the establishment of the museum gave rise to a sort of ethnographical revival. There were 195 donators to the museum in 1858 , and this number grew to 323 people in 1862 , and they donated 6,595 exhibits.

Since the museum was a public organization, its work mostly depended on the initiative of the members themselves. Even though sections of the museum were formed depending on the nature of the collections, they were not structurally organized like today's museum divisions with clearly defined collections and depositories, and with a set number of employees. One member of the board was assigned to each section and it was his responsibility to make a catalogue of the objects in this section. At the start the museum had the following sections: archæology, ma- 
naged by A.Kirkor; numismatics (coins and medals) by L.Rossyljon; archeography (documents, scripts, autographs) by M.Herburt; art (paintings, graphics, etching tables) by J.Wilczynski; memorabilia by P.Kukolnik; natural science by A.Adamowicz; library by M.Malinowski. ${ }^{34}$ During the history of the museum the sections changed: memorabilia disappeared, part of its exhibits went to the archæology section, and the remainder formed a sphragistic section; in 1862 a new ethnography section was added; in 1863 a collection of fortification models was obtained but it was not assigned to any specific section. ${ }^{35}$ Since the inventory books were not kept according to separate sections, new objects used to be registered in a common inventory book. Catalogues were made for the exhibits of archæology, art, ornithology, mineralogy, natural science, fortification models and for the library. ${ }^{36}$

\section{Cultural functions of THE MUSEUM AND ITS SIGNIFICANCE}

The Vilnius Museum of Antiquities, and the Archæology Board that worked with it, was the only science center in Lithuania. The collections were important for scientific research. At the same time it was a significant cultural institution, shaping certain social trends. The cultural influence of the museum was effective since it was so popular. The number of visitors fluctuated between 3 and 10 thousand a year. The report of the Board of Archæology given in 1862 proposing a memorial for Barbara Radziwill in Vilnius Cathedral shows how the directors of the museum understood the cultural mission of their institution. Even earlier, in 1853, E.Tyszkiewicz funded the rebuilding of the monument to Vytautas Mag- nus in Vilnius Cathedral. It was said in the above mentioned report that our "society calls on the generosity of Lithuanians, on their innate love of the nation, to help build a monument to Barbara in Vilnius Cathedral financed by voluntary donations" ${ }^{37}$ Love of the nation (civic consciousness) was considered the purpose of the cultural activity. Love of the nation by preserving its memories, meant not only honoring the nation's past but was also contributing to ensuring the nation's life in the future. And of course, involving society in this cultural action was a form of cultural and patriotic education. Similarly E.Tyszkiewicz was glad not only that the antiquities collected in the museum were protected against loss, but also that people's attitude toward old artifacts in their homes had changed. They were dragged out into the daylight dusted down and seen as important symbols of historical memory. ${ }^{38}$ The population however set the highest value on the historical lessons which the museum offered them.

The Vilnius Museum of Antiquities succeeded in becoming one of the centers of cultural and political consolidation of Lithuanian society. Such prominent Lithuanian public figures as M.Valancius, M.Akelaitis, J.Ciulda and others were members of the Archæology Board of the museum. The first exhibits of Lithuanian folk culture appeared in the museum. These were texts of folk songs, collected by K.Tyszkiewicz and given to the museum. ${ }^{39}$ M.Gusev, member of the Archæology board, established relations with the researcher into Lithuanian folk culture from Mazoji Lietuva (Small Lithuania), E. Gisevijus. ${ }^{40}$

The activity of the museum as an institution for unifying different and manifold elements of Lithuanian culture, for fostering love 
202 of the country, was halted by the Russification policy, carried out especially after the rebellion in 1863. In 1865 most of the exhibits from the Museum of Antiquities (primarily the most valuable ones) were selected and transported to Russia where they remain until this day. The rest of the exhibits were given to the Vilnius public library which was established by the government. ${ }^{41}$

We can judge the significance and perspectives of the museum by comparing it with the history of similar museums in other countries. The possible synthesis of folk and nobility cultures, mediated by the Vilnius Museum of Antiquities, reveals significant differences from the history of the Riga museum, established in 1834 on the initiative of Baltic German intellectuals. In the regulations of the History and Antiquities Association, which founded the museum, it was emphasized that in the Archæology section antiquities related to church and state life should be exhibited. ${ }^{42}$ These antiquities had nothing in common with Latvian folk culture. The above mentioned association tried to completely ignore the pagan aspects of this culture. Even much later, in 1882, preparing an exhibition of the Baltic cultural history monuments, it was decided not to include archæological objects. ${ }^{43}$ A few Latvian books were exhibited in this exhibition but almost all of them were Christian religious texts. ${ }^{44}$ Meanwhile in the Vilnius Museum of Antiquities the first of ten sections of the exhibition was one devoted to mythology. Very important exhibits in this section were the so-called statuettes of Lithuanian pagan gods. ${ }^{45}$ These Lithuanian mythological antiquities (even those that were not authentic), since they were common objects to ordinary people, as well as the elite, were able to become the basis of a common cultural identity in the future. However the destiny of the museum was much too dependent on the policy of the Russian government. For this reason, not only the museum but the whole of Lithuanian society suffered great losses.

\section{ReFERENCES}

1. A.H. Kirkor. Znaczenie i postep archeologii w naszych czasach, in: Pamiatniki kommissji archeologicznej Wilneskiej. p. 37-38.

2. K.Tiskevicius. Neris ir jos krantai. Vilnius, 1992, p. 32.

3. Quot. according to: M.Stolzman. Nigdy od ciebe miasto... Olsztyn, 1987. s. 54.

4. K.Tiskevicius. Op. cit. p. 43-44.

5. Ibid. p. 241.

6. Ibid. p. 252.

7. Ibid. p. 272.

8. Ibid. p. 159-160.

9. According to: T.Narbutt. Pomniejsze pisma historyczne szeglnie do historyi Litwy odnoszece sie. Wilno, 1856. s. 4-5, 222-223, 226.; S. Daukantas. Laiskai Teodorui Narbutui: epistolinis dialogas. Vilnius, 1996. p. 303-304, 520521.

10. According to: L.Jucevicius. Mokyti zemaiciai. Vilnius, 1975. p. 41-42, 68-69, 70-71, 116119, 121, 171, 186.

11. Feodaliniu zemës valdu inventoriu aprasymas (Sudarë V.Abramavicius). Vilnius, 1963. p. 308, 351, 365-366, 389, 391, 395, 414-415.

12. K. Tiskevicius. Op. cit. p. 32.

13. List T. Narbutta do d-ra A. Reniera 184404 22, in: Kronika rodzinna. 1888. t. 15. s. 358.

14. T. Narbutas. Lietuviu tautos istorija. Vilnius, 1992. p. 78.

15. Ibid. p. 169.

16. V. Zilënas. Lietuvos kolekcininkai ir muziejininkai. 3. Antanas Sutinas, in: Kulturos barai. 1983. 
Nr. 2. p. 62-63.

17. Katalog wystawy starozytnosci i predmiotw sztuki. Warszawa, 1856. s. 25-26, 29.

18. List T. Narbutta do d-ra A. Reniera 184212 20, in: Kronika rodzinna. 1888. t. 15. s. 331.

19. K Tiskevicius. Op. cit. p. 266.

20. T. Narbutt. Op. cit. p. 222

21. Z.Zygulski Jun. Muzea na swiecie. Warszava, 1982, s. 52-53.

22. S.S. Komornicki. Muzeum ksiazat Czartoryskich w Krakowie. Krakow, 1929. s. V.

23. C. Jankowski. Powiat oszmianski. Petersburg, 1896. t. I. s. 298.

24. A. Riszard. Szkola numizmatyczna, in: Wiadomosci numizmatyczno-archeologiczne. 1892. Nr. 4. s. 366.

25. M. Balinski. Pamietniki o Janie Sniadeckim. Wilno, 1856. t. I. s. 720-722.

26. Vilniaus universiteto istorija: 1579-1803. Vilnius, 1976. t. I. p. 246-247.

27. K. Tiskevicius. Op. cit. p. 31.

28. A. H. Kirkoras. Lietuva nuo seniausiu laiku iki 1882 metu. Vilnius, 1995. p. 106.

29. Posiedzenia akademickie i publiczne uniwersytetu imperatorskiego Wilenskiego w roku $1816 \mathrm{i}$ 1817, in: Dziennik Wilenski. t. VI. N. 36. s. 659.

30. Pamietniki kommissji archologicznej Wilenskiej. Wilno, 1856. s. 22-23.

31. Archeologijos komisijos posëdziu protokolai. VUB. F. 13. B. 234.

32. W. Dobaczewska. Dzieje kultury Wilenskiej pomiædzy dwoma powstaniami. Wilno, 1937. s. 32 .

33. Kuryer Wileski. 1857. N. 47. s. 404-405.

34. Pamiætniki kommissji archeologicznej Wileskiej. s. 10.

35. Archeologijos komisijos posëdziu protokolai. VUB. F. 13. B. 234.

36. Dnevnik zasedanij kommissii dlia razbora, privedenija v izvestnost i nadlezascij poriadok pred- metov, nachodiascichsia $v$ Vilenskom muzee

drevnostei. Vilno, 1865. s. 20.

37. Kuryer Wilenski. 1862. N. 39. s. 312.

38. Ibid. N. 55. s. 442.

39. Kuryer Wilenski. 1857. N. 51. s. 437.

40. Ibid. 1860. N. 16. s. 162-163.

41. E. Aleksandravicius, Kulturinis sajudis Lietuvoje 1831-1863 m. Vilnius, 1989. p. 47.

42. Ustav obscestva istorii i drevnostei ostzeiskich gubernij. Riga, 1834. s. 8.

43. Katalog der Rigaschen culturhistorischen Ausstellung. Riga, 1883. p. III.

44. Ibid. p. 36.

45. A. H. Kirkoras. Op. cit. p. 234.

Zygintas Bucys is historian and Vice Director of the National Museum of Lithuania.

Adr: Arsenalo str.

LT-2001 Vilnius

E-mail:zygintas@lnm.lt 


\section{FörfattARVÄGLEDNING}

Nordisk Museologi utges som ett forum för teoretisk och aktuell debatt inom det nordiska museiområdet och angränsande verksamhetsfält. Redaktionen strävar efter att erbjuda författare från många olika verksamheter och med skilda infallsvinklar utrymme med texter. Ställning till publiceringen tas i första hand av respektive landredaktör i Danmark, Finland, Norge och Sverige med hjälp av flera utomstående rådgivare. Insända artiklar returneras normalt icke. Tidskriftens språk är danska norska, svenska och engelska.

\section{Manuskript}

Manuskripten bör inte vara längre än 15 A4-sidor utskrivna med dubbelt radavstånd. Texten levereras (tillsammans med utskrift) som attachment per e-post eller som diskett med upplysning om operativsystem och textbehandlingsprogram. För att undvika merarbete vid redigeringen bör i den digitala texten

1. orddelning inte göras,

2. kursivering (ej understrykning) användas för betoning av ord eller mening,

3. andra typer av grafiska effekter markeras på utskriften,

4. styckeindelning markeras med tabulator, ej blanklinje,

5. hänvisas till noter med vanliga siffror (helst upphöjda siffror). Nottexterna samlas på ett blad efter texten, 6. rubriker och mellanrubriker skrivs med gemener, ej versaler.

\section{LITTERATURHÄNVISNINGAR}

Litteraturhänvisningar i texten kan ges med författare och tryckår, t.ex. (Hudson 1975). Referensen hänvisar därmed till en alfabetiskt ordnad litteraturlista efter artikeln. Den kan ställas upp på följande sätt: Hudson, Kenneth: A Social History of Museums. London 1975.

\section{INGRESS，RUBRIKER}

Texten bör helst sändas med förslag tilll en ingress på ca 50 ord, som skall tjäna som introduktion och locka till läsning. Det är en fördel med en förhållandevis kort huvudrubrik. Olika avsnitt av texten skiljs åt med mellanbrubriker.

\section{SUMMARY}

Eftersom Nordisk Museologi har ambitionen att kunna tjäna som ett samlande nordiskt organ internationellt läggs enegelska sammanfattningar av texter på skandinaviskt språk efter artiklarna. För att undvika sakliga missförstånd bör textförfattaren själv skriva ett förslag (ej över en A4-sida) till engelsk summary. Den språkgranskas genom redaktionens försorg före publicering.

\section{Bildmaterial, Figurer, TABELleR}

Bildmaterial kan medsändas digtalt, i form av diapositiv eller svart-vita fotografiska original. Tecknade figurer och tabeller levereras klara för tryck, helst i dubbelt format. Illustrationer numreras fortlöpande, illustrationstexter skrivs som eget dokument och det anges i textutskriftens kant var de lämpligen placeras. Textförfattaren svarar för att tillstånd till bildpubliceringen utverkats. Namn på fotograf och illustratör anges i bildtexten.

\section{FörfatTARUPPGIFT}

Tidskriften har visat sig fungera som underlag för ett fungerande nätverk mellan museologiskt intresserade. Det är därför viktigt att kunna ange författarnamn, postadress, e-mail och fax. Gärna också arbetsplats och ev. akademisk bakgrund.

\section{FRÅGOR OM PUBLICERING}

Frågor rörande publicering kan ställas till tidskriftens landredaktörer som nås på de adresser som anges på omslagets s. 2 eller till den f.n. anvarige huvudredaktören och svenske landredaktören Per-Uno Ågren. 